\title{
AFRICA'S SOFT POWER
}

PHILOSOPHIES, POLITICAL VALUES, FOREIGN POLICIES AND CULTURAL EXPORTS

Oluwaseun Tella

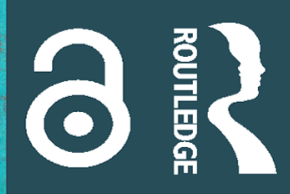


"This seven-chapter book is a powerful testimonial to consummate African scholarship. Its analysis is rigorous, insightful, lucid and authoritative, providing fresh perspectives on selected uniquely African philosophies, and the potentialities, deployment and limitations of soft power in Africa's international relations. The author rigorously Africanises the concept, broadening its analytic scope from its biased Western methodology, thus brilliantly fulfilling that great African proverb made famous by the inimitable Chinua Achebe: 'that until the lions have their own historians, the history of the hunt will always glorify the hunter'. This is truly an intellectual tour de force."

W. Alade Fawole, Professor of International Relations, Obafemi Awolowo University, Ile-Ife, Nigeria.

"This book addresses an important tool in the arsenal of foreign policy from an African perspective. African states have significant soft power capacities, although soft power is not always appreciated as a lever of influence, or fully integrated into countries' foreign policy strategies. Tella takes Nye's original concept and Africanises it, discussing Egypt, Kenya, Nigeria and South Africa via their respective philosophies of Pharaonism, Harambee, Omolúwàbi and Ubuntu. This study is a critical contribution to the literature on African foreign policies and how to use soft power to greater effect in building African agency on the global stage."

Elizabeth Sidiropoulos, Chief Executive, South African Institute of International Affairs, Johannesburg, South Africa.

"Soft power is seldom associated with African states, given decades bedevilled by coup d'états, brazen dictatorships and misrule. This ground-breaking book is certainly a tour de force in conceptualising soft power in the African context. It is a must read for experts and students of African diplomacy and international affairs."

Peter Kagwanja, President and Chief Executive, Africa Policy Institute, Nairobi, Kenya; and Adjunct Professor of Diplomacy and International Studies, University of Nairobi, Kenya. 


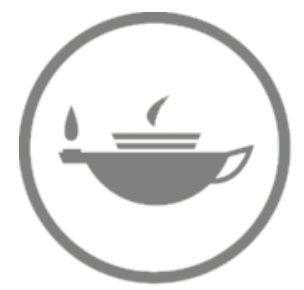

Taylor \& Francis Taylor \& Francis Group http://taylorandfrancis.com 


\section{Africa's Soft Power}

This book investigates the ways in which soft power is used by African countries to help drive global influence.

Selecting four of the countries most associated with soft power across the continent, this book delves into the currencies of soft power across the region: from South Africa's progressive constitution and expanding multinational corporations, to Nigeria's Nollywood film industry and Technical Aid Corps (TAC) scheme, Kenya's sport diplomacy, fashion and tourism industries, and finally Egypt's Pan-Arabism and its reputation as the cradle of civilisation. The book asks how soft power is wielded by these countries and what constraints and contradictions they encounter. Understandings of soft power have typically been driven by Western scholars, but throughout this book, Oluwaseun Tella aims to Africanise our understanding of soft power, drawing on prominent African philosophies, including Nigeria's Omolúwàbi, South Africa's Ubuntu, Kenya's Harambee, and Egypt's Pharaonism.

This book will be of interest to researchers from across political science, international relations, cultural studies, foreign policy, and African Studies.

Oluwaseun Tella is Director, The Future of Diplomacy, Institute for the Future of Knowledge, University of Johannesburg, South Africa. 


\section{Global Africa}

Series Editors: Toyin Falola and Roy Doron

Yoruba Oral Tradition in Islamic Nigeria

A History of DÀDÀKÚÀDÁ

Abdul-Rasheed Na'allah

Development in Modern Africa

Past and Present Perspectives

Edited by Martin S. Shanguhyia and Toyin Falola

\section{Borders, Sociocultural Encounters and Contestations}

Southern African experiences in Global view

Edited by Christopher Changwe Nshimbi, Inocent Moyo \& Jussi Laine

\section{Governance and Leadership Institutions in Nigeria}

Edited by Ernest Toochie Aniche and Toyin Falola

\section{African Indigenous Knowledges in a Postcolonial World}

Essays in Honour of Toyin Falola

Edited by Olajumoke Yacob-Haliso, Ngozi Nwogwugwu and Gift Ntiwunka

\section{Nigerian Female Dramatists}

Expression, Resistance, Agency

Edited by Bosede Funke Afolayan

\section{Bessie Head and the Trauma of Exile}

Identity and Alienation in Southern African Fiction

Foshua Agbo

\section{Africa's Soft Power}

Philosophies, Political Values, Foreign Policies and Cultural Exports

Oluwaseun Tella

\section{The Life and Times of Chinua Achebe}

Kalu Ogbaa

\section{Illicit Financial Flows from South Africa}

Decolonial Perspectives on Political Economy and Corruption

Edited by Serges Djoyou Kamga 


\section{Africa's Soft Power}

Philosophies, Political Values, Foreign

Policies and Cultural Exports

\section{Oluwaseun Tella}

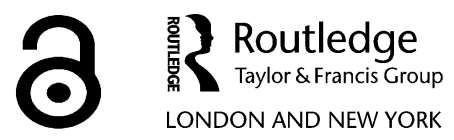


First published 2021

by Routledge

2 Park Square, Milton Park, Abingdon, Oxon OX14 4RN

and by Routledge

52 Vanderbilt Avenue, New York, NY 10017

Routledge is an imprint of the Taylor \& Francis Group, an informa business

(C) 2021 Oluwaseun Tella

The right of Oluwaseun Tella to be identified as author of this work has been asserted by him in accordance with sections 77 and 78 of the Copyright, Designs and Patents Act 1988.

The Open Access version of this book, available at www.taylorfrancis.com, has been made available under a Creative Commons Attribution-Non Commercial-No Derivatives 4.0 license.

Trademark notice: Product or corporate names may be trademarks or registered trademarks, and are used only for identification and explanation without intent to infringe.

British Library Cataloguing in Publication Data

A catalogue record for this book is available from the British Library

Library of Congress Cataloging-in-Publication Data

Names: Tella, Oluwaseun, author.

Title: Africa's soft power : philosophies, political values, foreign policies and cultural exports / Oluwaseun Tella.

Other titles: Global Africa ; 21.

Description: Abingdon, Oxon ; New York, NY : Routledge, 2021. | Series: Global Africa ; 21 Includes bibliographical references and index.

Identifiers: LCGN 2020057540 (print) | LCGN 2020057541 (ebook) | ISBN 9781032008356 (hardback) | ISBN 9781003176022 (ebook)

Subjects: LCSH: Power (Social sciences)-Africa. | Africa-Foreign relations-Philosophy. | Nigeria-Foreign relations. | South Africa-Foreign relations. | Egypt-Foreign relations. | Kenya-Foreign relations.

Classification: LCG JZ1773 .T385 2021 (print) | LCG JZ1773 (ebook) | DDC 327.96-dc23

LC record available at https://lccn.loc.gov/2020057540

LC ebook record available at https://lccn.loc.gov/2020057541

ISBN: 978-1-032-00835-6 (hbk)

ISBN: 978-1-032-00836-3 (pbk)

ISBN: 978-1-003-17602-2 (ebk)

DOI: $10.4324 / 9781003176022$

Typeset in Baskerville

by Taylor \& Francis Books 


\section{Contents}

List of tables

Acknowledgements viii

ix 


\section{Tables}

1.1 Soft Power $30 \quad 2$

1.2 Global Soft Power Index 3

1.3 The eight largest economies in Africa 4

3.1 Grants received by Nollywood 44

3.22015 MAMA Awards 46

3.32016 MAMA Awards 47

3.4 Nigeria's contribution to UN peacekeeping operations 54

3.5 Corruption Perception Index 65

3.6 Freedom in Africa 66

4.12015 MAMA awards $\quad 84$

4.22016 MAMA AWARDS 84

4.3 Times Higher Education top 10 African universities 88

4.4 Cybermetrics Lab top 10 African universities 88

4.5 Top ten most admired African brands in $2020 \quad 102$

$\begin{array}{ll}4.62020 \text { Global Peace Index } & 105\end{array}$

4.7 Migrant acceptance index 113

5.1 The ten countries with the highest number of jobs created in the $\begin{array}{ll}\text { travel and tourism sector } & 124\end{array}$

5.2 Top ten remittance recipients in $2018 \quad 129$

5.3 Top ten troop contributors to the United Nations 135

$\begin{array}{lll}6.12019 \text { IAAF top } 10 \text { medallists } & 151\end{array}$

6.2 Top ten countries of origin of tourists visiting Kenya 153

6.3 International Criminal Court cases 164

6.4 Kenya's ranking in the Corruption Perception Index 170 


\section{Acknowledgements}

There is no gainsaying that a writer's life is a lonely one. However, I found myself in the deepest solitude while writing this book owing to a major life challenge, particularly in the year the manuscript was completed.

This book grew out of my previous research on soft power published in journal articles and book chapters. For several years, I have engaged how Nigeria, South Africa, the United States, and the emerging economies of Brazil, Russia, India, and China (BRIC) wield their soft power resources in Africa. I have also examined the place of soft power in regional governance, focusing on the African Union (AU). This has provided me (in this book) with the opportunity to present my thoughts on how the regional powers in Africa Nigeria and South Africa as well as Egypt and Kenya - have exercised their soft power on the continent and beyond. Thus, in my deepest solitude, I had to rely on the support of family, friends, and colleagues without whom this book would not have been completed.

First, I would like to thank the ultimate soft and hard power force - Almighty God - who saw me through arguably the most challenging period of my life. I am also grateful to my aunt, Mrs Omolola Faluade, who provided the moral and spiritual support I needed during the period. I completed the first draft of the book at her house in Pietermaritzburg, South Africa. I also relied heavily on the spiritual and moral support of Pastors Tunde Obokhai, Maltida Obokhai, and John Mowoe, and my spiritual brother, Dr Adeoye Akinola.

I would like to extend my sincere gratitude to my colleagues at the Institute for the Future of Knowledge, University of Johannesburg, particularly the formidable Director, Professor Alexander Broadbent, and Director of Research, Anthony Kaziboni, for their unwavering support in the final year of this project. The high value the Institute places on research contributed to the success of this book. I also owe a profound debt of gratitude to my parents and siblings for their support during challenging times.

I hope that this seminal work on Africa's soft power will make a significant contribution to academic scholarship on regional powerhood and foreign policy in Africa. I also hope that this contribution will shape the decisions of African policymakers in an increasingly globalised world where the need for effective deployment of soft power cannot be overemphasised. 


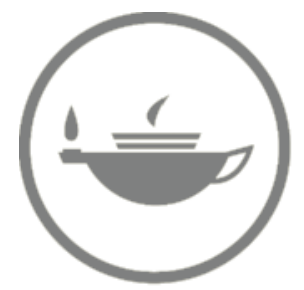

Taylor \& Francis Taylor \& Francis Group http://taylorandfrancis.com 


\section{Introduction}

\section{Background and context: soft power in Africa}

Since Joseph Nye coined the term in the 1990s, the concept of soft power has become a buzzword among policymakers, scholars, journalists, and keen observers of international relations across the globe. Yet, African scholarship on soft power remains undeveloped and this is the first book publication on African soft power. I have defined soft power elsewhere as "a state's non-coercive capability (ranging from its foreign policies and political values to its cultural exports) that engenders other states' attraction, admiration and aspirations" (Tella, 2016: 153). I further argue in the same article that the three As are the critical attributes of soft power as other actors are attracted by, adopt the model, and aspire to achieve a similar level of prosperity as the soft power state. While this definition captures the essence of soft power, it does not sufficiently reflect some aspects of African states' soft power capacity. For example, Nigeria's Omolúwàbi, South Africa's Ubuntu, Kenya's Harambee, and Egypt's Pharaonism are not highlighted. These are critical African philosophies that are relevant to the countries' actual and potential soft power. It is therefore imperative to conceptualise soft power to sufficiently accommodate the African context.

There are few studies of Africa's soft power, with virtually none in terms of Egypt and Kenya, but a growing body of literature with regard to Nigeria and South Africa. Despite increasing interest among scholars of international relations in the latter countries' (particularly South Africa's) soft power, the African philosophies noted earlier have not been captured in the conceptualisation of the term. Against this backdrop and for the purpose of this book, I define soft power as an actor's (including state and non-state) ability to influence the action, inaction, position, and behaviour of other actors through its non-coercive capability - including its philosophy, culture, values, and policies - that engenders these actors' attraction, admiration, and aspirations.

In light of the increasing relevance of soft power in international politics, two major institutions have emerged to develop indices and set indicators to it. These are The Soft Power 30 by Portland and Global Soft Power Index by Brand Finance. The Soft Power 30 is not comprehensive as it only focuses on 30 states, which are largely Western countries. Table 1.1 shows the 2019 Soft Power 30.

DOI: $10.4324 / 9781003176022-1$ 


\section{Introduction}

Table 1.1 Soft Power 30

\begin{tabular}{|c|c|c|}
\hline Rank & Country & Score \\
\hline 1 & France & 80.28 \\
\hline 2 & United Kingdom & 79.47 \\
\hline 3 & Germany & 78.62 \\
\hline 4 & Sweden & 77.41 \\
\hline 5 & United States & 77.40 \\
\hline 6 & Switzerland & 77.04 \\
\hline 7 & Canada & 75.89 \\
\hline 8 & Japan & 75.71 \\
\hline 9 & Australia & 73.16 \\
\hline 10 & Netherlands & 72.03 \\
\hline 11 & Italy & 71.58 \\
\hline 12 & Norway & 71.07 \\
\hline 13 & Spain & 71.05 \\
\hline 14 & Denmark & 68.86 \\
\hline 15 & Finland & 68.35 \\
\hline 16 & Austria & 67.98 \\
\hline 17 & New Zealand & 67.45 \\
\hline 18 & Belgium & 67.17 \\
\hline 19 & South Korea & 63.00 \\
\hline 20 & Ireland & 62.91 \\
\hline 21 & Singapore & 61.51 \\
\hline 22 & Portugal & 59.28 \\
\hline 23 & Poland & 55.16 \\
\hline 24 & Czech Republic & 54.35 \\
\hline 25 & Greece & 53.74 \\
\hline 26 & Brazil & 51.34 \\
\hline 27 & China & 51.25 \\
\hline 28 & Hungary & 50.39 \\
\hline 29 & Turkey & 49.70 \\
\hline 30 & Russian Federation & 48.64 \\
\hline
\end{tabular}

Source: author's adaptation from Portland (2019).

Table 1.1 clearly illustrates the dominance of Western countries, with no African country featuring in the index. While soft power is not often associated with African states, the methodology deployed is partly responsible for these results. Among the 25 countries that were polled, Africa only had two representatives - Egypt and South Africa. Brand Finance's Global Soft Power Index provides a more comprehensive list of soft power countries and indicators. It highlights the soft power of 60 states and features four African countries - South 
Africa, Egypt, Algeria, and Nigeria. While Portland's Soft Power 30 relies on six indicators, namely, Culture, Education, Engagement, Digital, Enterprise, and Government; Brand Finance's Global Soft Power Index has seven broader indicators including: Business and Trade, Governance, International Relations, Culture and Heritage, Media and Communication, Education and Science, and People and Values. Brand Finance also conducted their polls in 87 countries including 20 African countries. It is not therefore surprising that four African states feature on the Index. Table 1.2 reveals the African and global ranks of the African states that feature in Brand Finance's Global Soft Power Index.

While this index has its shortcomings such as the non-inclusion of the African philosophies mentioned earlier, it presents more comprehensive and acceptable data, given the methodology adopted. Three (Nigeria, South Africa, and Egypt) of the four case studies in this book feature in this index. Like other East African countries, Kenya does not appear in this index. However, the aim of this book is to engage the soft power currencies of key states in the four key sub-regions on the continent - North Africa, Southern Africa, West Africa, and East Africa (a state in the last sub-region in Africa - Central Africa - has not been included because none of the states in the sub-region, including Cameroon and the Democratic Republic of Congo (DRG) features in the soft power index, projects remarkable soft power and exercises significant influence in Africa) - hence the inclusion of Kenya. While Nairobi's power in the East African sub-region is contested by countries such as Ethiopia and Tanzania, Kenya's robust philosophy and cultural output including Harambee, fashion, achievements in athletics, and tourism justify its inclusion.

The case for Egypt is less controversial despite the fact that its regional powerhood is challenged by Algeria and Morocco in the sub-region. No other state in North Africa has influenced the politics in the sub-region and the broader Middle East like Egypt. Cairo's reputation as the cradle of civilisation and perceptions that it is the foremost Arab country also justify its inclusion. Unlike the two aforementioned countries, the choice of Nigeria and South Africa seems pretty straightforward given that their hegemonic profile is not contested by other countries in the West and Southern African sub-regions, respectively. These two countries are the largest economies and the major peacemakers on the continent. South Africa's progressive constitution (regarded as one of the most liberal in the world), and the spread of its multinational corporations across the continent are

Table 1.2 Global Soft Power Index

\begin{tabular}{llll}
\hline Country & African rank & Global rank & Index score \\
\hline South Africa & 1 & 36 & 36.4 \\
Egypt & 2 & 38 & 34.8 \\
Algeria & 3 & 54 & 29.0 \\
Nigeria & 4 & 56 & 28.8 \\
\hline
\end{tabular}

Source: author's adaptation from Brand Finance (2020). 
Table 1.3 The eight largest economies in Africa

\begin{tabular}{llll}
\hline Country & African rank & Global rank & GDP (millions of US dollars) \\
\hline Nigeria & 1 & 30 & 397,270 \\
South Africa & 2 & 33 & 368,289 \\
Egypt & 3 & 44 & 250,895 \\
Algeria & 4 & 55 & 173,758 \\
Morocco & 5 & 59 & 117,921 \\
Angola & 6 & 62 & 105,751 \\
Kenya & 7 & 66 & 87,908 \\
Ethiopia & 8 & 68 & 84,356 \\
\hline
\end{tabular}

Source: author's adaptation from World Bank (2019).

also important criteria. The influence of Nigeria's film industry (Nollywood) and the popularity of its music (Afrobeats) on the continent are equally germane in this regard.

Beyond their soft power capabilities, it is important to note that these states are also the most significant hard power (especially in economic terms) states in their respective sub-regions and on the continent at large. Table 1.3 shows the largest economies in Africa.

As Table 1.3 shows, Nigeria, South Africa, and Egypt are the largest economies in Africa. Kenya is ranked seventh, outstripped by Algeria, Morocco, and Angola. However, Kenya is the highest ranked East African state on the index. In terms of military capability, the 2020 Global Fire Power Index reveals that Egypt, Algeria, South Africa, Nigeria, and Angola are the top five military powers in Africa, with Kenya occupying twelfth position (Global Fire Power, 2020). It is thus clear that African soft power states exhibit similar characteristics to those across the rest of the world. The most powerful states in hard power terms also fare well in soft power capabilities including the United States, China, France, Germany, India, the United Kingdom, and Brazil.

\section{Scholarship on Africa's soft power}

In comparison with other African states, there is an impressive literature on South Africa's soft power. The original scholarship engages the sources and optimisation of the country's power of attraction (van der Westhuizen, 2008; Geldenhuys, 2008; Graham, 2008; Smith, 2012; Chiroro, 2012; Sidiropoulos, 2014; Ogunnubi and Isike, 2015; Tella, 2017a). While Sidiropoulos (2014) identifies the two major sources of South Africa's soft power as the manner of its political transition and the 1996 liberal constitution, Ogunnubi and Okeke-Uzodike (2015) suggest more comprehensive sources, including its music, soap operas, literature, art, entertainment industry, celebrities, universities, sport achievements and hosting of international sporting events, as well as ethnic and racial diversity. Political currencies span South Africa's liberal democracy, progressive 
constitution, political transition, and its iconic leaders, with foreign policies sources including its membership of international organisations and norm entrepreneurship.

Smith (2012) notes that while scholars have made reference to South Africa's soft power in its international engagement, the centrality of this concept is often trivialised. Highlighting the sources of South Africa's soft power such as the global status of Nelson Mandela, acting as a bridge builder between the Global North and Global South, and multilateral initiatives, she submits that soft rather than hard power has been more salient to South Africa's foreign policy behaviour. I extend this debate by arguing that South Africa's soft power currencies justify its membership of the emerging economies of Brazil, Russia, India, China, and South Africa (BRICS) despite the fact that the economic capabilities of other BRICS states are disproportionate to that of the African state. Given that one of the objectives (at least in theory) of BRICS is to distort the international order in a bid to stem the United States' global dominance, I argue that Pretoria is well placed to use its soft power resources and soft balancing behaviour to challenge Washington's dominance in Africa (Tella, 2017a).

Following the emergence of President Jacob Zuma's administration and South Africa's declining image during this period, critical studies on Pretoria's soft power (Tella and Ogunnubi, 2014; Ogunnubi and Amao, 2016; van der Westhuizen, 2016; Tella, 2018a) emerged. van der Westhuizen (2016) bemoans the fact that the country lost the international prestige (disproportionate to its hard power capacity) which it enjoyed in the immediate period after its political transition. He submits that such favourable international status was due to the influence of Nelson Mandela, the country's liberal constitution, and human rights promotion in international affairs. However, these soft power resources have been tarnished due to the Dalai Lama being denied entry to South Africa, and the country's stance against United Nations (UN) resolutions critical of the human rights situation in Zimbabwe and Myanmar. This is complicated by three factors that have undermined Pretoria's soft power: incessant xenophobia, the fiasco leading to the emergence of Nkosazana Dlamini-Zuma as the Chair of the African Union (AU) in 2012, and other African countries' lack of appreciation of South Africa's peacemaking efforts on the continent (van der Westhuizen, 2016).

In an earlier study, with Olusola Ogunnubi, we focus on the contradiction posed by xenophobia with regard to South Africa's soft power (Tella and Ogunnubi, 2014). We conclude that the anti-immigrant sentiments that are ubiquitous in South Africa could erode the country's soft power gain and regional leadership in Africa. Ogunnubi and Amao (2016) highlight xenophobia and leadership inconsistencies as major constraints to South Africa's soft power. I provide a more comprehensive analysis of the challenges to South Africa's soft power in a study from 2018, in which I analyse the constraints including socio-economic and political challenges such as parliamentary brouhaha, racial tension, the triple challenges of poverty, inequality, and unemployment; and the contradictions presented by xenophobia and South Africa's double standards on human rights in international affairs (Tella, 2018a). 


\section{Introduction}

Some studies such as Ogunnubi and Isike (2015), Smith (2011), Bodomo (2009), and Tella (2017a, 2020) have offered a comparative perspective on South Africa's soft power profile by juxtaposing Pretoria's power of attraction with those of other regional and great powers specifically Nigeria and the BRIC countries. Others have examined South Africa's exercise of soft power in a particular realm. Dowse (2011) and Grix and Lee (2013) engage the nexus between South Africa's soft power and sporting activities. Masters (2015) examines the possible role of parliamentary diplomacy in augmenting Pretoria's soft power and April (2009) explores the potential impact of civil society groups in optimising South Africa's soft power. It is thus clear that the literature on South Africa's soft power gambit has grown remarkably.

In recent times, Nigerian scholars have begun to show an interest in the country's soft power - a concept that had been neglected in the country's robust foreign policy and regional powerhood literature. In what could be argued is the most comprehensive study on Nigeria's soft power to date (Tella, 2018b), I ask a critical question: is Nigeria a soft power state? I identify the sources of Nigeria's soft power as its cultural exports illustrated by its music and movies; its foreign policies of peacemaking, democracy promotion, membership of international organisations, and technical aid; and the relative success of its political transition to democracy, the success of an opposition party in the 2015 presidential elections (a rarity in Africa), and its status as the largest democracy in Africa. However, I also note (Tella, 2018b) that despite these soft power resources, Nigeria has not always been successful in translating them to actual influence, particularly in its pursuit of its foreign policy objectives, resulting in a gap between power and influence. I then highlight the limitations to Nigeria's soft power including political corruption, Boko Haram terrorism, a poor international image, and Nigerian citizens' involvement in illicit activities (drug trafficking, human trafficking, and internet scams) abroad, arguing that all these factors have frustrated Nigeria's power conversion as the country does not farewell in all major indices that measure good governance and Nigerian citizens are being jailed, deported, and killed abroad, rubbishing the significance of citizen diplomacy. It is against this backdrop that I submit that Nigeria is a potential soft power state (Tella, 2018b).

In their comparative study of Nigeria and South Africa's soft power, Ogunnubi and Isike (2015) identify and engage two sources of Nigeria's power of attraction: Nollywood and mega churches that they describe as the country's "most obvious" soft power resources. In another study, they deploy the three sources of soft power identified by Nye - culture, foreign policy, and political values - to highlight Nigeria's soft power (Ogunnubi and Isike, 2018). The cultural factors discussed cover Nollywood, music, food, language, dress, and sporting activities; the political values are democratic credentials and foreign policy includes public goods and Afrocentrism. The authors note the constraints to Nigeria's soft power including human rights violations, high levels of inequality, environmental pollution, and insecurity and submit that Abuja needs to tackle these domestic bottlenecks in order to be well placed to exercise its soft power. 
Recently, I have examined soft power individuals in Nigeria and South Africa using case studies of Olusegun Obasanjo and Thabo Mbeki during and post their presidencies (Tella, 2020). The soft power of these individuals which rub off on their respective countries - derived from their idiosyncratic traits and their ideas with regard to African integration contributed to their success. In an earlier study, I engage the attractions and limitations of Nigeria's soft power focusing on Nollywood and the Technical Aid Corps (TAC) scheme, which I regard as potentially the most potent cultural export and foreign policy tool to generate Nigeria's soft power (Tella, 2017b). I further identify Boko Haram terrorism and political corruption as the twin problems that puncture the country's soft power.

Adesina (2017) bemoans that African countries lag behind the rest of the world in taking advantage of their cuisines to exercise soft power internationally. Her study engages the nexus between culinary diplomacy and soft power and notes the potential soft power benefits for Nigeria such as economic gains and cultural exports, if serious attention is paid to culinary diplomacy. Akinola and Ogunnubi (2020) explore the potential impact of a popular television reality show, Big Brother Naija, on Nigeria's soft power. They submit that beyond its entertainment value, the show should be seen as a veritable tool to promote Nigerian foreign policy objectives as it has the potential to shape viewers' perceptions of the country. I investigate the place of soft power in Boko Haram terrorism and counter-terrorism efforts, arguing that the sect has suffered a significant loss of the soft power it enjoyed in its early stages due to its resort to heavy reliance on violence (Tella, 2018c). I further argue that while there is an element of soft power in its counter-terrorism efforts, Abuja deploys a significant measure of hard power in its fight against the terrorist group, concluding that smart power (an effective combination of hard and soft power) is required to win the war against the sect (Tella, 2018c). Idowu and Ogunnubi (2018) examine the nexus between economic diplomacy and Nigeria's soft power. They argue that economic diplomacy that promotes Nigeria's foreign policy objectives and takes cognisance of citizens' needs is critical to promoting Abuja's soft power.

In terms of Egypt and Kenya, there are few studies on these countries' soft power, reflecting the neglect of this dimension of power in the foreign policy and regional powerhood literature in these states. The notable exceptions are El Rehim (2017) and Mwanika (2014). El Rehim (2017) engages the decline of Egypt's soft power following the 11 September 2001 terrorist attacks in the United States. The author also argues that there has been a resurgence in one element - diplomacy - of Cairo's soft power since 2014, exemplified by its emergence as a non-permanent member of the UN Security Council. Mwanika (2014) explores Kenya's display of soft power in its conflict mediation and strategic engagement in Somalia between 2002 and 2012. The author argues that while the country leaned towards soft power approaches in the intervention, it encountered various challenges. The study thus recommends a number of initiatives for Kenya's future interventions. 


\section{Introduction}

\section{Approach and content}

This book has seven chapters. This chapter lays the foundation, presents the background, engages existing studies on the subject matter, and provides a working definition and an overview of the book's major themes. Chapter 2 sets out to de-Americanise and Africanise the concept of soft power. It engages Nye's conceptualisation of the term and observes that since its first operationalisation in his 1990 book titled Bound to Lead, Nye has successfully used the concept to portray the United States' subtle capacity in his numerous publications on the subject. The chapter notes that Nye's conceptualisation is, however, biased towards the United States as it emphasises US popular culture, liberal ideals, and foreign policy behaviour. It is against this backdrop that the chapter attempts to deAmericanise the concept by analysing the BRIC countries' soft power whose resources (China and Russia in particular) do not exactly fit Nye's conceptualisation. It argues that these non-Western states have successfully wielded their soft power to achieve some of their foreign policy objectives. The chapter then engages the soft power attributes of the African case studies that are not captured by Nye's ideas. These include Nigeria's Omolúwàbi, South Africa's Ubuntu, Kenya's Harambee, and Egypt's Pharaonism.

Chapter 3 focuses on Nigeria's soft power capacity. It outlines the sources of the country's soft power that stems from its philosophy of Omolúwàbi; its cultural exports in the form of Nollywood, Afrobeats, its diaspora, and literature; and its policies of democracy promotion, peacemaking, and aid which finds practical expression in the foreign policy instrument of the TAC scheme. The chapter argues that the gains reaped by Nigeria from its soft power posture include economic ones, the internationalisation of its culture provided by Nollywood and Afrobeats, its successful promotion of democracy across the continent, its recognition as a major peacemaker on the continent and subsequent representation of the continent in international bodies such as being a non-permanent member of the UN Security Council, and its leadership role in regional and sub-regional organisations including the AU and the Economic Community of West African States (ECOWAS). Despite these gains, Nigeria has not significantly exercised its soft power to achieve its foreign policy objectives due to many domestic and external constraints including political corruption, insecurity, and an image problem.

Chapter 4 examines South Africa's soft power. It identifies the philosophy of Ubuntu; the cultural outputs of soap operas and universities; the values of constitutionalism, liberal democracy, and human rights; and the foreign policies of peacemaking and democracy promotion as sources of Pretoria's soft power. The chapter illustrates that South Africa is arguably the most successful state on the continent in terms of using its soft power to achieve the desired results. This is evident in the country's hosting of key international events like the 2010 FIFA World Cup and its role as Africa's sole representative in key international institutions such as the BRICS and the Group of 20 (G20). Despite its impressive soft power sources, South Africa is constrained on many levels including its economic constraints of poverty, inequality, and unemployment, political constraints of 
political corruption and state capture; and contradictions - double standards on human rights and perpetual xenophobia. These challenges have tarnished its image across the globe, resulting in the decline of the regional power's soft power.

Chapter 5 analyses Egypt's soft power profile, drawing attention to its philosophy of Pharaonism; its cultural exports in the form of its ancient civilisation, its entertainment industry, and literature; and its foreign policy of Pan-Arabism and its image as the stabiliser in the Middle East region. Egypt's soft power has yielded positive returns including its strategic partnership with the West in efforts to manage the Israeli-Palestinian conflict and its image as the foremost Arab nation in the region. However, Cairo's soft power declined following the 2011 Arab Spring, which resulted in ongoing political instability and economic challenges. Despite this, Egypt's version of Pan-Arabism remains the most important in the Arab world.

Chapter 6 explores Kenya's soft power, which stems from its philosophy of Harambee; cultural exports including its fabrics, the success of its athletes in international sporting events, its wildlife and landscape's tourist attraction, cultural festivals; and its idealistic and pacific foreign policy and economic diplomacy. The chapter argues that Kenya has benefitted from its soft power posture as seen in its annual attraction of tourists from across the globe. This has promoted Nairobi's foreign policy objective of economic diplomacy as the tourist sites contribute to the country's Gross Domestic Product (GDP). In addition, key multinational organisations such as China Global Television Network (GGTN) and Toyota have established their regional offices and assembly plants in Kenya. However, political corruption, ethnicity, the tussle with the International Criminal Court (ICG), and high levels of electoral violence which have characterised the political landscape of the East African country have punctured its soft power capacity.

Chapter 7 presents a synthesis and summarises the book's major findings and conclusions by focusing on the successes and challenges of the major African actors in exercising their soft as opposed to their hard power in pursuit of their foreign policy objectives.

\section{References}

Adesina, O. (2017). "Projecting Nigeria's Soft Power through Culinary Diplomacy." African Fournal for the Psychological Study of Social Issues 20 (1): 140-149.

Akinola, A. and Ogunnubi, O. (2020). "Soft Power or Wasteful Entertainment? Interrogating the Prospect of 'Big Brother Naija'." The Round Table, doi:10.1080/ 00358533.2020 .1717088$.

Aluko, O. and Ogunnubi, O. (2018). "Nigeria's Soft Power and Economic Diplomacy in Africa." Journal of African Foreign Affairs 5 (2): 189-206.

April, Y. (2009). "Assessing South Africa's Strategic Options of Soft Power Application through Civic Interest Groups.” African Fournal of Conflict Resolution 9 (1): 123-144.

Bodomo, A. (2009). "Africa-China Relations: Symmetry, Soft Power and South Africa." The China Review 9 (2): 169-178.

Brand Finance (2020). Global Soft Power Index 2020. London: Brand Finance. 
Chiroro, B. (2012). South Africa: Optimising the Currency of Soft Power in the International Arena. Briefing No. 79. Pretoria: Africa Institute of South Africa.

Dowse, S. (2011). Power Play: International Politics, Germany, South Africa and the FIFA World Cup. Occasional Paper No. 82. Johannesburg: South African Institute of International Affairs.

El Rehim, A. (2017). "The Potential of Egypt's Soft Power Post Arab Spring." Geopolitics under Globalization 1 (1): 12-16.

Geldenhuys, D. (2008). "The Idea-Driven Foreign Policy of a Regional Power: The Case of South Africa." In: Regional Powers Network (RPN) conference, German Institute of Global and Area Studies (GIGA), Hamburg, Germany, 15-16 September.

Global Fire Power (2020). 2020 Military Strength Ranking. https://www.globalfirepower. $\mathrm{com} /$.

Graham, S. (2008). "Gold Star or Bottom of the Class: Is South Africa a Good International Citizen?" South African Fournal of International Affairs 15 (1): 87-97.

Grix, J. and Lee, D. (2013). "Soft Power, Sports Mega-Events and Emerging States: The Lure of The Politics Of Attraction." Global Society 27 (4): 521-536.

Idowu, A. and Ogunnubi, O. (2018). "Nigeria's Soft Power and Economic Diplomacy in Africa." Fournal of African Foreign Affairs 5 (2): 189-206.

Masters, L. (2015). "South Africa's Emerging Parliamentary Diplomacy and Soft Power." Strategic Review for Southern Africa 37 (2): 74-93.

Mwanika, P. (2014). Kenya's Diplomacy on the Somali Conflict and Strategic Intervention: Soft-Power Diplomacy and Stabilization Dynamics. Scholar's Press.

Nye, J. (1990). Bound to Lead: The Changing Nature of American Power. New York: Basic Books.

Ogunnubi, O. and Amao, O. (2016). "South Africa's Emerging 'Soft Power' Influence in Africa and its Impending Limitations: Will the Giant Be Able to Weather the Storm?" African Security 9 (4): 299-319.

Ogunnubi, O. and Isike, C. (2015). "Regional Hegemonic Contention and the Asymmetry of Soft Power: A Comparative Analysis of South Africa and Nigeria." Strategic Review for Southern Africa 37 (1): 152-177.

Ogunnubi, O. and Isike, C. (2018). "Nigeria's Soft Power Sources: Between Potential and Illusion?" International Fournal of Politics, Culture and Society 31 (1): 49-67.

Ogunnubi, O. and Okeke-Uzodike, U. (2015). "South Africa's Foreign Policy and the Strategy of Soft Power." South African Fournal of International Affairs 22 (1): 23-41.

Portland (2019). Soft Power 30. London: Portland.

Sidiropoulos, E. (2014). "South Africa's Emerging Soft Power." Current History 113 (763): 197-202.

Smith, K. (2011). "South Africa and India as Regional Leaders: Gaining Acceptance and Legitimacy Through the Use of Soft Power." In: Modi, R. (ed.), South-South Cooperation: Africa on the Centre Stage. Basingstoke: Palgrave Macmillan.

Smith, K. (2012). "Soft Power: The Essence of South Africa's Foreign Policy." In: Landsberg, C. and van Wyk, J. (eds), South African Foreign Policy Review. Pretoria: Africa Institute of South Africa, pp. 68-83.

Tella, O. (2016). "A Declining or Stable Image? An Assessment of the United States' Soft Power in Africa." South African Fournal of International Affairs 23 (2): 151-166.

Tella, O. (2017a). "South Africa in BRICS: The Regional Power's Soft Power and Soft Balancing." Politikon 44 (3): 387-403.

Tella, O. (2017b). "Attractions and Limitations of Nigeria's Soft Power." Fournal of Global Analysis 7 (2): 109-128.

Tella, O. (2018a). "Currencies, Constraints and Contradictions of South Africa's Soft Power." Journal of Asian and African Studies 53 (3): 420-436. 
Tella, O. (2018b). "Is Nigeria a Soft Power State?" Social Dynamics 44 (2): 376-394.

Tella, O. (2018c). "Boko Haram Terrorism and Counter-Terrorism: The Soft Power Context." Journal of Asian and African Studies 53 (6): 815-829.

Tella, O. (2020). "Soft Power Individuals in Nigeria and South Africa: An Appraisal of Olusegun Obasanjo's and Thabo Mbeki's Power of Attraction." Round Table 109 (5): 574-585.

Tella, O. and Ogunnubi, O. (2014). "Hegemony or Survival: South Africa's Soft Power and the Challenge of Xenophobia." Africa Insight 44 (3): 145-163.

van der Westhuizen, J. (2008). "Popular Culture, Discourse and Divergent Identities: Reconstructing South Africa as an African State." African Identities 6 (1): 45-61.

van der Westhuizen, J. (2016). "South Africa's Soft Power Conundrum: How to Win Friends and Influence People in Africa." Fournal of Political Power 9 (3): 449-465.

World Bank (2019). World Development Indicators. Washington DC: World Bank. 


\section{De-Americanising and Africanising soft power}

\section{Nye's conceptualisation of soft power}

The concept of soft power was coined by US Political Scientist, Joseph Nye, in his 1990 masterpiece titled Bound to Lead. As early as this period, Nye had realised the increasing cost of using military force compared with non-coercive power in achieving a state's desired outcomes in its relations with other states. While the direct use of power persists today, there is increasing acknowledgement of the relevance of indirect use of power which is often less costly and confrontational. According to Nye, due to the costs often incurred when coercive power is applied, less threatening sources of power are becoming more critical. He notes that "in an age of information-based economies and transnational interdependence, power is becoming less transferable, less tangible, and less coercive" (1990: 33). Nye describes the direct use of power as hard power or command power which he argues is derived from "inducements ('carrots') or threats ('sticks')". He illustrates that indirect use of power is soft or co-optive power, which rests on "the attraction of one's ideas or on the ability to set the political agenda in a way that shapes the preferences that others express" (Nye, 1990: 31). Nye (1990) identifies economic and military capabilities as the most important sources of hard power; and culture, ideology, and institutions as the major resources of soft power. The traditional currencies of power (hard power) are increasingly becoming insufficient to tackle the myriad of contemporary realities in international politics; thus, the capacity to deploy effective communication and multilateral institutions has become essential. Nye (1990: 32) further argues that:

soft co-optive power is just as important as hard command power. If a state can make its power legitimate in the eyes of others, it will encounter less resistance to its wishes. If its culture and ideology are attractive, others will more willingly follow. If it can establish international norms that are consistent with its society, it will be less likely to have to change. If it can help support institutions that encourage other states to channel or limit their activities in ways the dominant state prefers, it may not need as many costly exercises of coercive or hard power in bargaining situations.

DOI: $10.4324 / 9781003176022-2$ 
As in hard power, power conversion, which Nye (1990: 27) defines as "the capacity to convert potential power, as measured by resources, to realised power, as measured by the changed behavior of others" is important in exercising soft power. Nye extends this argument in a 2004 book titled Soft Power and describes the concept as "the ability to shape the preferences of others". While Nye argues that soft power capability can be derived from attractive personality, political values, culture, policies, and institutions that appear legitimate in the eyes of actors, he notes that the major sources of this source of power are culture, political values, and foreign policy. Nye (2004) concedes that hard power seems to have an edge over soft power in terms of ease of measurement and appears more concrete. A state's economic capacity, military force, population, and territory can easily be measured, unlike culture, political values, and foreign policy. However, he notes that soft power can be measured through polls and focus groups (Nye, 2004).

While Nye (2004; 2008) emphasises that soft power is the power of attraction as opposed to hard power (power of coercion), he concedes that attraction does not always guarantee other actors' preferences. This gap between power as resource and power as influence is not peculiar to soft power. Despite the United States' and South Africa's global and regional military prowess, they were disgraced in Vietnam and Lesotho, respectively. Nye (2004) argues that the distinction between hard and soft power is sometimes blurred given that some states may be attracted to other states' military power due to the appeal derived from the latter's invincibility. On the other hand, hard power resources may be deployed to establish institutions that eventually enjoy legitimacy (Nye, 2004). Similarly, a state that experiences decline in its hard power capacity is likely to witness a reduction in its attractiveness (Nye, 2004).

The relevance of soft power is perhaps most appreciated in the context of states such as Norway and Canada whose influence in international affairs significantly outweighs their military and economic capabilities (Nye, 2004). In responding to critics of soft power such as Niall Ferguson, Nye argues that these scholars often view soft power as cultural resources as against influence on behaviour. He notes the inability of Coke and Big Macs to shape the behaviour of Muslim people across the globe towards the United States and the incapacity of pizza and American movies and music to influence North Korean leader Kin Jong II's nuclear programme (Nye, 2004). This does not, however, imply that culture does not produce soft power. American culture is globalised and its appeal cannot be denied (Tella, 2016). It is against this backdrop that, in highlighting the influence of Hollywood in China, Nye (2004: 12) states that "if American objectives include the strengthening of the legal system in China, such films may be more effective than speeches by the American ambassador about the importance of the rule of law". A state's cultural soft power is also promoted through personal contact and exchanges. This is seen in the ideas that American universities promote to hundreds of thousands of foreign students in these institutions (Nye, 2004).

In terms of policies, Nye (2004: 14) illustrates that a government's policies can bolster or undermine a state's soft power: "Domestic or foreign policies that 
appear to be hypocritical, arrogant, indifferent to the opinion of others, or based on a narrow approach to national interests can undermine soft power." This was evident in the George W. Bush administration's foreign policy in the "war on terror" and the subsequent decline in American attractiveness. Thus, soft power relies on credibility and a state that is perceived as manipulative loses its credibility (Nye, 2011). Foreign policy objectives that augment soft power include peacemaking, democracy and human rights promotion, and foreign aid. While hard power is more important in preventing attacks, border security, and protecting allies, soft power is more significant in promoting human rights, democracy, and the free market (Nye, 2004). Unlike hard power that is largely derived from governments, soft power mainly rests on the shoulders of civil society. Indeed, multinational corporations, universities, churches, and non-governmental organisations' (NGOs) soft power may reinforce or undermine the foreign policy goals of their home countries (Nye, 2004).

Nye (2009) is of the view that it is desirable for a state to be able to shape the preferences of others, resulting in less reliance on hard power. Nonetheless, an effective combination of the power of attraction and power of coercion (smart power) is often required to achieve the desired outcomes. Nye (2009) further argues that "contextual intelligence" - the skill to deploy smart strategies - is required to effectively combine hard and soft power. One can then deduce that while President Barack Obama exercised some level of "contextual intelligence" in his foreign policy posture, President Donald Trump lacks it. Nye (2009) highlights the place of smart power in the United States' Cold War efforts. While the US military contained Soviet hostility, US ideas undermined communism, underscoring the fact that "success is the result not merely of whose army wins but also of whose story wins" (Nye, 2009: 162-163). The line between hard and soft power is sometimes blurred, as hard power resources can generate attraction and soft power resources can engender coercion (Nye, 2011). For example, a well-managed military, and military diplomacy including multinational cooperation and training programmes, can enhance a state's soft power (Nye, 2011).

It should, however, be noted that Nye's soft power is not a novel idea. Gramsci (1971) engages Western cultural hegemony in relation to other cultures across the globe. He observes that:

Even if one admits that other cultures have had an importance and a significance in the process of "hierarchical" unification of world civilisation (and this should certainly be admitted without question), they have had a universal value only in so far as they have become constituent elements of European culture, which is the only historically and concretely universal culture - in so far, that is, as they have contributed to the process of European thought and been assimilated by it.

(Gramsci, 1971: 765)

It is clear that culture is one of the major sources of soft power identified by Nye; thus, Gramsci's idea is relevant to Nye's conceptualisation of soft power. 
Similarly, Carr (1946) identifies the major sources of power as military power, economic power, and power over opinion. While military and economic power are coercive capability or hard power resources, power over opinion relates to a state's attractive capacity (soft power) to set the agenda and determine public opinion. Indeed, opinion polls are one of the major instruments to measure the efficacy of states' soft power.

One of the major critics of soft power, Niall Ferguson (2009) identifies cultural and commercial goods as the sources of soft power and notes that these sources are too "soft" to generate significant influence, pointing to how Islamic states consume US products such as Coke, McDonald's, and Hollywood and American music, yet they do not love the US more. While this is true, it is important to note that the United States' use of hard power in the Islamic world has also not made Muslims around the world love the United States. Indeed, as various polls such as Gallup and Pew Research show, and Nye observes, anti-Americanism in the Muslim world largely stemmed from the United States' hawkish foreign policy in the Middle East, particularly during George W. Bush's administration exemplified by the war on terrorism (Gallup, 2010; Pew Research Centre, 2008; Nye, 2004). Other critics, mostly of realist extraction, seem reluctant to accept the concept of soft power as some of the agents of such power, particularly nonstate actors do not fit in the realist state-centric analysis (Seymour, 2020). However, the increasing importance of non-state actors in modern times means that their soft power and by extension influence in international affairs can no longer be neglected.

There is no gainsaying that Nye's conceptualisation of soft power is biased towards the United States. The major sources of soft power he identifies - culture, political values, and foreign policies - demonstrate US preponderance and have been successfully deployed to maintain US global dominance. Nye (2004: 31) argues that:

The countries that are likely to be more attractive and gain soft power in the information age are those with multiple channels of communication that help to frame issues; whose dominant culture and ideas are closer to prevailing global norms (which now emphasise liberalism, pluralism, and autonomy); and whose credibility is enhanced by their domestic and international values and policies.

These are clearly US and by extension Western values and cultures that do not fit neatly into other domestic contexts around the world including Africa, Asia, and Latin America.

\section{De-Americanising soft power}

While Nye's conceptualisation is biased towards the United States, the concept of soft power has been embraced and adapted to fit local contexts by policymakers and scholars in countries across the globe. The US media (both traditional and 
social) serves as an important tool of "power over opinion" and has thus been critical to the country's successful wielding of soft power. This is seen in the influence of Hollywood, Cable News Network (CNN), Disney, the Entertainment and Sports Programming Network (ESPN), Discovery, Time, and social media such as Google, Facebook, Twitter, and YouTube (Thussu, 2014). The United States has maintained hegemony in this realm and has used these platforms to spread its culture, political values, and foreign policies. It is for this reason I argue that " $[\mathrm{t}]$ here is no gainsaying that the US is a soft power state. Its culture is globalised, its political values are admired across the world and its foreign policies have global consequences" (Tella, 2016: 151). However, there has been increasing growth of the media in other countries including China, India, Brazil (Thussu, 2014), Russia, and Qatar.

Traditional Western media such as CNN, the British Broadcasting Corporation (BBC), and France 24 are increasingly being challenged by emerging media from the Global South, including Qatar's Al Jazeera, Russia's Russia Today (RT), China's China Global Television Network (CGTN), and India's New Delhi Television (NDTV). These global television channels present international affairs issues from the perspective of the Global South to challenge the viewpoints of the mainstream Western media. Thussu (2014) argues that Al Jazeera's coverage of NATO's invasion of Libya, the Syrian crisis, and other important Middle Eastern issues reflects how Qatar has used its media to shape politics in the region. Similarly, RT's coverage of the Russo-Ukrainian War and the Syrian conflict highlighted Russian viewpoints on the conflict as opposed to the Western media that portrayed the West's position.

\section{China: the dragon's charm offensive}

Despite its human rights abuses and record of repression, Beijing has improved its image in the global arena, emerging from a state perceived as a threat to one regarded as a benefactor (Kurlantzick, 2007), thanks to its soft power attributes. Kurlantzick (2007: 6) asserts that:

When Nye coined the term soft power, he excluded elements like investment and trade and formal diplomacy and aid - elements he considered more concrete carrots and sticks .... In the context of China, both the Chinese government and many nations influenced by China enunciate a broader idea of soft power than did Nye. For the Chinese, soft power means anything outside of the military and security realm, including not only popular culture and public diplomacy but also more coercive economic and diplomatic levers like aid and investment and participation in multilateral organizations.

Similarly, Ding (2010: 265) notes that:

As a developing country and a relatively marginalized player at the outset in the post-Cold War world order, China has a different set of concerns and 
must tap different sources of soft power. Thus China's soft power wielding must be understood and re-conceptualized on the Chinese, rather than Nye's terms.

While Nye's sources of soft power largely reflect the attributes of democratic states, some authoritarian states like China are more strategic in wielding soft power than are democratic ones (Kurlantzick, 2007). Beijing is increasingly seen as a constructive player and a role model across Southeast Asia. Acknowledging the relative weakness of its hard power currencies, Chinese policymakers and academics developed the concept of "peaceful rise" and later "peaceful development" to guide Beijing's behaviour in international affairs. It is hoped that promoting peace will: enhance the growth of China's economy; foster national cohesion; generate opportunities for its companies in foreign lands; invigorate its science and technology capabilities; and, most importantly, obtain resources to feed China's growing economy (Kurlantzick, 2007).

Chinese leaders have portrayed China in a positive light through their rhetoric, speeches, and declarations. For example, former President $\mathrm{Hu}$ Jintao asserted that " $[\mathrm{h}]$ istory tells us that any attempt by a country to realize its interests through the use or threat of force, or to place its interests above those of other nations, will get nowhere" (Kurlantzick, 2007: 40). Similarly, President Xi Jinping stated that "[w]e should increase China's soft power, give a good Chinese narrative, and better communicate China's messages to the world" (Shambaugh, 2015: 99). These speeches point to the value China places on soft power in its engagement with other actors across the globe. Xi Jinping has launched various initiatives such as the Chinese Dream, the Silk Road Economic Belt, the 21st Century Maritime Silk Road, the Asia-Pacific Dream, and the Belt and Road Initiative (BRI) across the globe to bolster China's soft power. Aside from the influence of CGTN, Xinhua News Agency is a significant Chinese media outlet. The news agency has been instrumental in promoting the worldview of the Communist Party domestically and in the international arena (Shambaugh, 2015). Xinhua is also driven by the profit motive and sees itself as competing with other prominent news channels like Associated Press, Reuters, and Bloomberg.

Confucianism is the basis of traditional Chinese culture and has remarkable influence in Asia. While Confucian values were relegated to the background in the past, the ascendance of China has been accompanied by the rise of Confucian values in East Asian countries. It is interesting to note that some of the core values of Confucianism, such as the notion of the primacy of the group rather than the individual, are antithetical to American values. Other values include promotion of harmony and order, diligence, prudence, the pre-eminence of the family in the social structure, and the significance of virtues and ethics (Cho and Jeong, 2008). The Chinese government has made tremendous progress in infusing Confucian values into Chinese ideology and foreign policy. The Chinese Confucian democracy seeks to establish a harmonious society, peopleoriented policies, and a socialist view of rewards and punishment (Cho and 
Jeong, 2008). In terms of foreign policy, China's external relations are partly driven by key principles like peaceful co-existence, prosperity and safety, and the promotion of a harmonious world through Confucianism.

In recent decades, there has been increased international interest in Chinese culture. Accordingly, the Chinese government has made tremendous efforts to spread the Chinese culture in Asia and globally. Beyond Asia, it has sponsored Chinese cultural festivals in North America, Europe, Australia, and Africa, and the Chinese Hànyǔ Shuípíng Kăoshì (HSK) - an equivalent of Teaching of English as a Foreign Language (TOEFL) - has drawn candidates from across the world (Gill and Huang, 2006), with a dramatic increase in the number of foreign students showing an interest in studying in China. Huang and Ding (2006) observe that within ten years the number of foreign students in China tripled, with the majority from Asian countries, especially South Korea and Japan. In 2016, more than 440,000 international students were studying in China, an increase of 35 per cent from 2012. China accounts for the most international students in Asia and is ranked third globally behind the United States and the United Kingdom (UK) (China Power, 2017). While it can be argued that the rising Chinese economy is a major source of attraction to foreign students, Chinese culture is also important as illustrated by the vast number of students enrolling in disciplines embedded in this culture such as Chinese language, arts, history, philosophy, and traditional Chinese medicine (Huang and Ding, 2006). The most popular non-language degrees among foreign students include medicine, engineering, management, and economics, with disciplines such as education, agriculture, and science becoming increasingly popular (China Power, 2017).

Beijing established the first Confucius Institute in South Korea in 2004. By 2018, China had founded more than 500 Confucius Institutes across the globe (Council on Foreign Relations, 2018). The primary responsibilities of the institutes are to showcase Chinese culture in their host countries. They also strive to portray a positive image of China to other countries. As Nye (2004) rightly points out, when a state is able to draw foreign students from across the globe, they imbibe the culture of the state and, when they return to their home countries, they may become sympathetic to the cause of that state. Against this backdrop, Gill and Huang (2006) observe that around 15 years ago, official Chinese statistics showed that approximately 30 former foreign students in China were ministers in their countries, more than 10 were ambassadors to China, and in excess of 120 were senior staff at universities in their countries.

China's domestic values and policies are also important sources of its soft power. The economic reforms that began in the late 1970s that led to the adoption of economic liberalism, and the resultant impressive economic growth and performance over recent decades, have significantly boosted the country's image around the world and its model is considered as worthy of emulation. Contrary to the Washington Consensus, the Beijing Consensus (BJG) does not embrace "one size fits all" policies for countries' economic problems. This concept/theory draws together the different aspects of Chinese soft power, delineates the 
powerful links between economic strength and soft power, and explains China's capabilities. Ramo (2004: 1112) explains the three central themes of the BJC: the key to development is "bleeding-edge innovation" to "create change that moves faster than the problems change creates"; a fundamental need to shift development's focus to individuals, and their "quality-of-life" with sustainability and equality as priorities; and a security doctrine which stresses self-determination through the use of leverage and asymmetry.

According to Ramo (2004), the BJC encompasses three attributes for a developing country in the international system. The first is the search for innovation and pragmatic reforms to proffer solutions to problems, while the second is a developmental model that emphasises people's quality of life rather than per capita Gross Domestic Product (GDP). The third attribute is commitment to selfdetermination in its external relations in order to be assertive in the international system and prevent being dictated to by other great powers. All these factors reinforce China's parallel ideas and roadmap in comparison to those of the United States. Particularly since the 2008 financial crisis, the Chinese model has gained wider currency in scholarly writing and public analysts' debates. In the words of Robert Kaplan, "China shows you can have economic freedom without political freedom, where we used to think they were indivisible" (quoted in Gill and Huang, 2006: 21). Indeed, it was the Washington Consensus with its emphasis on democracy and market fundamentalism that caused the 2008 global financial crisis. While the BJC is, at the political level, authoritarian, it has promoted economic growth, giving China the image of wealth across the globe.

In other words, China has been able to blend an authoritarian political system with some elements of economic liberalism and this has worked well for the great power. China's soft power is mainly based on its recent economic success, and it will be interesting to see if this translates into broader international influence or a desire by others to emulate the Chinese model. The success of this model has appealed to a number of countries. Russia has prioritised how it can improve its economy rather than democracy. Other members of the Commonwealth of Independent States (CIS) such as Uzbekistan, Turkmenistan, and Kazakhstan have also embraced the Chinese economic model. Within Asia, former Indian Prime Minister, Manmohan Singh, remarked that India should emulate the Chinese model to promote economic growth and global trade (Gill and Huang, 2006). In Latin America former Brazilian President, Luis Inacio Lula da Silva, was reported to have sent investigative teams to study the Chinese economic model, and in the Middle East conservative leaders in Iran have been influenced by the Chinese model (Gill and Huang, 2006). As one observer indicated, "from Vietnam to Syria, from Burma to Venezuela, and all across Africa, leaders of developing countries are admiring and emulating what might be called the China Model" (Zhao, 2010: 419).

Following the United States' foreign policy failure and economic setback and the attendant recent criticism of Western liberal ideas, the Chinese model appears to be an alternative to many developing countries striving for economic development. In contrast to the West, which demands compliance with certain 
principles such as democracy, transparency, good governance, the rule of law, and respect for human rights from many states before establishing cordial relations, China's relations with other states are largely determined by economic and strategic interests (Zhao, 2010). Thus, countries that have been sanctioned and isolated by the West for non-compliance with those principles find a friend in China that seems prepared to establish a relationship without meddling in their domestic political affairs. Accordingly, countries like Iran and Zimbabwe, against which the Western world has applied sanctions due to their domestic politics, enjoy close ties with China.

Beijing's foreign policy is undoubtedly another instrument of its soft power. In the post-Mao period, China "has adopted a less confrontational, more sophisticated, more confident and, at times, more constructive approach toward regional and global affairs" (Gill and Huang, 2006: 21). This posture is geared towards a stable international system which enables China to concentrate on domestic issues and its economy. According to official statements, China desires to promote international norms such as peaceful settlement of disputes and combating of global threats like terrorism and climate change, as well as disarmament and arms control (Huang and Ding, 2006).

In order to counteract negative perceptions, especially the perceived threat that accompanies the rise of China, Beijing has promoted the strategies of peaceful rise and peaceful development in the global arena. According to Cho and Jeong (2008), Chinese scholars agree that the concept of peaceful rise has transformed the country's foreign policy objectives in three significant directions. First, China's neighbours are now the cornerstone of its foreign policy rather than the United States. Second, there has been a shift in foreign policy from striving for acceptance in the international community to playing a global role as a player of magnitude. Third, policy is now targeted towards economic development to harness resources to boost all the major elements of state power. Thus, the peaceful rise strategy connotes the policies implemented by China towards becoming a true global player, particularly through harnessing its national power. China's ascendance as a great power possibly prompted its policymakers to substitute the peaceful rise slogan with peaceful development. Cho and Jeong (2008) argue that it is a mere change of term as there appears to be a negligible difference. The change in nomenclature may have been informed by increasing realisation that Beijing has already risen and can now develop alongside the other great powers.

Beijing has also come to appreciate the importance of multilateral institutions in the pursuit of its foreign policy. The China-Association of Southeast Asian Nations (ASEAN) free trade area has given China an opportunity to establish closer ties with the East Asian countries and it seeks to tilt the balance of power politics between China and the United States in this region in its favour. In 2003, China became a member of the Southeast Asia Treaty of Amity and Cooperation and has also been actively involved in regional security talks like the ASEAN Regional Forum (ARF). Its contribution to UN peacekeeping missions cannot be overemphasised. Beijing supplies the largest number of peacekeepers among the 
five permanent members of the UN Security Council, having deployed more than 40,000 to over $30 \mathrm{UN}$ peace missions across the globe in the last three decades (Tella, 2019). By September 2019, China had 2,521 peacekeepers in eight conflict zones including Mali, the DRC, Darfur, Cyprus, South Sudan, the Western Sahara, and the Middle East (Tella, 2019). At 15 per cent of the UN peacekeeping budget, China is the second largest contributor behind the United States, which contributes 28 per cent. However, unlike Washington, Beijing makes its contribution in full and on time. China was also a prominent player in the establishment of the Shanghai Cooperation Organisation (SCO), which aims to establish common ground in political, economic, and security concerns that cut across China, Russia, Kazakhstan, Kyrgyzstan, Tajikistan, and Uzbekistan.

Whether or not a specific aspect of soft power is attractive to a specific foreign country very much depends on the particular conditions in that country. As such, what one country sees as a soft power held by China might be seen differently by another country. China's capacity to wield its soft power is constrained by a number of factors. The BJC places much emphasis on pragmatism rather than moral appeal, which may significantly win the hearts and minds of other states (Zhao, 2010). The Chinese model is also characterised by income inequality, massive environmental pollution, and high levels of corruption (Xinbo, 2010). The projection of a state's soft power largely rests in the realm of civil society. Given the strong state and weak civil society in China, the Asian power has been unable to adequately harness the resources of NGOs and multinational corporations to promote the Chinese brand around the world.

\section{Russia: the resurgence of the Kremlin}

During the Cold War, the Soviet Union wielded its soft power primarily in terms of its political and economic values of socialism. The Soviet brand of socialism provided an alternative to Western capitalism, which is still characterised as imperialist by many across the world. Soviet socialism was attractive to some European, Asian, African, and Latin American countries. The high economic growth rate recorded in the Soviet Union in the period immediately following the end of World War II and the successful launch of Sputnik in 1957 created the impression in the hearts and minds of many that the Soviet Union was "ahead" of the United States. This in turn bolstered the former's soft power (Nye, 2004). With the collapse of the Soviet Union and its appealing socialist ideology, Russia, particularly under Putin's administrations, realised the need to develop and wield other sources of soft power in at least the CIS. This did not prove too difficult given the economic growth following Putin's emergence as President in 2000 (his first stint) and the increasing importance of Russia's gas and oil in the region.

The sources of Russian soft power include its goods, which range from natural resources to finished goods, its culture popularised by satellite television, its film industry, rock music, and the perceived availability of jobs for its immediate neighbours (Hill, 2006). Russia has attracted millions of people from Central Asia, Caucasus, and the other parts of Eurasia in search of greener pastures due 
to the visa-free policy implemented by Moscow and the majority of the CIS states. In the first half of 2019, 2.4 million migrant workers entered Russia with contiguous states, including Uzbekistan, Tajikistan, Kyrgyzstan, Ukraine, and Kazakhstan contributing the largest portion, totalling 918,000, 524,000, 265,000, 165,000, and 105,000, respectively (The Moscow Times, 2019). Labour migrants from faraway places like China, Germany, Turkey, the UK, and the United States arrived in the same period (The Moscow Times, 2019). Laruelle (2015: 10) asserts that:

Gazprom, Rosneft, Itera and Lukoil helped Moscow to develop an energybased soft-power strategy toward Ukraine, and to a lesser extent Central Asia, by controlling pipelines, building new processing plants and overseeing the gas station business. Electricity-production firms (RAO-Unified Energy System, but also private actors such as RusAl) embodied Russian influence in the hydropower sector in Kyrgyzstan, Tajikistan, Moldova, Armenia, and Georgia. Russian banks and investment firms displayed such dynamism that they largely shaped the banking sector of the entire CIS.

It is thus clear that the economic survival of most of the CIS states rests on the shoulders of Russia, augmenting Moscow's soft power. Unlike the Soviet Union, Russia (with a few exceptions such as Georgia in 2008 and Ukraine in 2014) has placed primacy on its economic power rather than its military strength in its international relations with the states in its region. It has successfully used its economic prowess to persuade its neighbours to agree with its terms with regard to regional policies (Hill, 2006). Russia's dominance in the economies of the CIS is notable. The country's energy agreement with Turkmenistan cedes control to the former of the latter's gas until 2028. The Russian state electricity firm is the major supplier of electricity in Georgia. In order to repay a debt of $\$ 40$ million, Armenia gifted its nuclear power station to Moscow and a Russian energy company is responsible for Armenia's gas transportation (Tsygankov, 2006).

Russian is the most important language in the region and has served as a significant pull factor for citizens of post-Soviet Union states that are considering migrating to Russia. Many citizens of the CIS, particularly Ukraine, Belarus, and Moldova, understand Russian as it is the language of commerce, work, and education in some CIS states (Ćwiek-Karpowicz, 2012). In illustrating the potential of Russia's soft power, Hill (2006: 342) posits:

If the influx of migrants from surrounding regions continues; if Russian business investment grows in neighboring states; if regional youth continue to watch Russian TV and films and purchase Russian software, CDs and DVDs, and other consumer products; and especially if the heavy hand of Moscow is pulled back and the hand of commerce is extended instead in Russian foreign policy, Russia will achieve the economic and cultural predominance in Eurasia that the US has in the Americas. 
In order to counteract American influence and the appeal of Western democracy and institutions, Russia has developed its own ideology, which emphasises its own brand of democracy, the so-called "sovereign democracy", and has been vocal in its criticism of Western democracy and the manner in which it is being promoted across the globe. Russian "sovereign democracy" promotes limited citizen participation in the political process. According to Popescu (2006), the term emphasises two ideas: sovereignty and Russian values. Sovereignty in this context basically refers to non-interference from the West in the domestic affairs of states, especially CIS states. Russian values are considered democratic values, which take into consideration the distinctive historical and domestic realities of the country and significantly diverge from the Western conception of democracy. To this end, the "rule of law, protection of minorities, a free press, a viable political opposition, or legally guaranteed property rights are not part of the reality of the sovereign democracy" (Popescu, 2006: 1). The concept of sovereign democracy serves two major purposes: first, it provides a democratic cover for Putin's authoritarian administration and subsequently provides domestic legitimacy and prevents international criticism, and second, it challenges the universality of Western ideas of democracy and human rights (Popescu, 2006).

The Russian government has deliberately promoted policies targeted at the outside world to influence their perception of the Kremlin, particularly through the establishment of government-sponsored organisations. It is within this context that the Russiky Mir Foundation, which was founded in 2007, can be located. The official primary objective of the organisation is to promote the Russian language and culture in general as one of the major civilisations in today's world. The mass media has provided an important avenue through which the Kremlin promotes its soft power. Particularly through the Internet and television stations, Russia has been able to reach the CIS states and beyond. For instance, in 2005, Russia established RT, a television station that broadcasts in Russian, English, Arabic, and Spanish to more than 100 countries across five continents. Online news outlets including Regnum and Nory Region also reinforce Russian positions in the CIS and Central Asia. In a similar vein, Russian newspapers including Komsokolskaya Pravda and Argumenty i Fakty have paid more attention to their special editions in the CIS countries, and Rossiyskaya Gazete works closely with heavyweight international newspaper outlets such as the Washington Post, Daily Telegraph, and Le Figaro with regard to the editing of Rossiyskaya Gazete's monthly report on Russian politics for foreign audiences (Ćwiek-Karpowicz, 2012). Most CIS citizens prefer the Russian media to Western media as it is in Russian and also because of the historical ties that still bind these states together.

However, Russia's power of attraction seems to be limited to the CIS states. Moscow's political corruption, abuse of human rights, and authoritarianism contribute to the soft power deficit. This is complicated by the limited global spread of the Russian language. A cursory examination of how Russia strives to promote its soft power within its immediate region, reveals that one of the main objectives is to counteract the influence of the United States and its Western 
partners. It is partly within this context that one can understand Russia's hawkish diplomacy in Georgia in 2008 and Ukraine in 2014.

\section{India: pacifism and Bollywood}

There is no gainsaying that India is a soft power state and this partly explains why New Delhi's rise has not been greeted with the level of suspicion accompanying China's ascendency. India's soft power is visible in South East Asian states due to a shared culture and traditions (Purushothaman, 2010). The country's cultural influence is also ubiquitous in other states across the world including Iran, South Africa, and South East Asia, owing to historical cultural links. India's Bollywood, diaspora, music, and art have spread like wildfire across the globe. In South East Asia, the Indian culture is evident in the temples of Cambodia, Thailand, and Indonesia (Purushothaman, 2010). India's Buddhism is practised globally and it has a strong presence in Sri Lanka, Cambodia, Laos, Thailand, Myanmar, Japan, Vietnam, Singapore, China, Korea, Taiwan, and Tibet. The reach of India's yoga cannot be overemphasised. It is widely believed to be efficient for stress relief and is a form of exercise whose reach permeates the entire world.

Partly due to its huge diaspora across the globe, Indian foods are not only popular in Asia but also in faraway places including the Americas, Europe, and Africa. The Indian movie industry - Bollywood - is the largest in the world, outstripping Hollywood. Indian movies appeal to an international audience and movies such as Slumdog Millionaire and Three Idiots have taken the entertainment world by storm, illustrated by the large number of viewers and the global accolades they received. Slumdog Millionaire won eight Oscar Awards in 2009. It goes without saying that Bollywood has successfully penetrated Europe, Africa, Asia, and the Middle East (Blarel, 2012). Indeed, Indian soft power is evident in Africa; consider the Bollywood film industry and the Indian food outlets across the continent. Appreciation of Bollywood in the Global South stems from its promotion of family and communal values as opposed to US values that are characterised by individualism. The films' emphasis on religion, gender balance, and lack of sexual content are also sources of attraction as seen in their appreciation in the Muslim-dominated northern part of Nigeria (Thussu, 2014). Bollywood has also had a significant impact on local content in the movie and music industries in Indonesia (Thussu, 2014).

The Indian Council for Cultural Relations (ICCR) was established in 1950 to formulate and implement policies on India's external cultural relations and strengthen the country's cultural relations with states across the world. The Council has established Chairs of Indian Studies - to ignite foreign students' interest in Indian culture - in universities across the world in places such as China, Poland, the United States, Canada, Switzerland, Nigeria, Morocco, Turkey, Italy, Trinidad and Tobago, and Spain (Indian Council for Cultural Relations, 2019).

In the realm of foreign policy, the non-violent methods promoted by India's charismatic leader, Mahatma Gandhi, in the struggle for independence have 
contributed to its positive image. New Delhi has always tilted towards a multilateral approach in its international relations. As Nye (2004) pointed out, when a state's foreign policy is seen by others to be inclusive, the efficacy of its soft power is enhanced. On the other hand, when it is regarded as unilateral or arrogant, this undercuts its soft power. India was one of the states to condemn colonisation and global armaments. The country represented the interests of developing states at the UN, particularly under the administration of Jawaharlal Nehru (Wagner, 2012). India was a pioneering member of the General Agreement on Tariffs and Trade (GATT) in 1947, the United Nations Conference on Trade and Development (UNCTAD), and the formation of the non-aligned movement (Wagner, 2012). In 2003, alongside Brazil and South Africa, India formed the IBSA Dialogue Forum with the primary objective of promoting cooperation among these countries and the developing world at large. In 2009, India, Brazil, Russia, and China established BRIC, which was later joined by South Africa, to alter the international balance of power in their favour against a US dominated order. India has also displayed its soft power in the area of humanitarian action, evident in its role in the 2004 Indian Ocean tsunami and more recently in the ongoing coronavirus pandemic during which it has provided medical supplies to states in its region and beyond, particularly those that requested the Asian power's assistance in these difficult times (Tourangbam, 2020).

In terms of political values, India has gained respect as the largest democracy in the world and its democracy has been stable. The country has not experienced military rule since independence (Purushothaman, 2010). Despite its shortcomings, India's democracy has revealed to developing nations that democracy can be effective irrespective of a state's level of development and positionality in the North-South divide. This can be attributed to India's relatively successful elections since independence and an inclusive system which ensures that even conventionally marginalised groups participate in governance. According to Wagner (2012), India's recorded success with regard to democracy is unprecedented among states that gained independence after World War II. This motivated states such as Bhutan and Nepal to embrace democracy (Purushothaman, 2010).

Democratic states are usually characterised by a high level of citizen involvement in the decision-making process and rule is by consent of the governed. Arguably, India's democracy gives New Delhi an edge over Beijing in terms of the soft power garnered from political values. It is against the backdrop of India's democratic credentials, growing economy and status as a responsible nuclear power that the United States worked closely with India to guarantee the latter an international waiver from nuclear sanctions (Jaishankar, 2018). In recent times, states such as Bangladesh, Nepal, Maldives, and Afghanistan have sought India's assistance in managing their elections and drafting their constitutions (Jaishankar, 2018). However, violations of human rights by state institutions such as the police and the military and the Indian rape culture coupled with corruption and infrastructure decay have dented India's image in the eyes of the world. This perhaps explains why Indian democracy is not regarded by many states as a model to emulate. 


\section{De-Americanising and Africanising soft power}

Nevertheless, given the potential in India for economic growth, cultural richness, and democratic values, it is an Asian power with the capacity to influence the major issues of contemporary international politics. India has been able to manage relations with its rivals in its region (China and Pakistan) and has become more influential in the Persian Gulf, Asia, the Indian Ocean, and Africa in addition to establishing commendable relations with great powers like the United States. It is an emerging great power, especially when one considers its size and population and the fact that it owns nuclear weapons. However, India's soft power is undermined by factors ranging from widespread corruption to pervasive poverty, child labour, and violence against women (Jaishankar, 2018).

\section{Brazil: Samba and Carnivals}

Since the twentieth century, Brazil has pursued an agenda of playing an active role in the international system and, by extension, influencing international rules as could be expected of a major player in international politics. Brazil's belief in itself as a big state destined to play an active role in world affairs motivates the country to successfully amass its power profiles, most importantly its soft power currencies to achieve its foreign policy objectives. Brazil has also shown the desire to be more assertive in its region, in the Global South, and in multilateral agreements. Accordingly, it has worked tirelessly to deepen relations with other emerging powers like China and Russia, establish South-South relations with countries like India and South Africa, influence regional and global trade negotiations, and to become a permanent member of the UN Security Council (De Lima and Hirst, 2006).

Brasilia has relied heavily on its soft power both within its region and in the world at large. Given the changing pattern of power in international politics and the increasing importance of attracting other states rather than coercing them, Brazil's international behaviour appears appropriate. Its culture is highly valued across the globe and its pacifist tradition is widely commended and has won it respect from other states. As Nye (2004) points out, if a state culture is embedded in values shared by others, such state is able to exercise soft power. Brazil has benefitted significantly from the relative peace and absence of great power rivalry in South America, promoting the country's adoption of a non-violent policy towards conflict resolution and boosting its soft power across the world, especially with regard to regional hegemonic competence in negotiation and diplomacy in international politics (Bertonha, 2010).

In terms of its popular culture, Brazil's football, samba, and carnival have always appealed to other states. Brazil has always been regarded as a soccer nation. It not only enjoys the status of having won the highest number of World Cup trophies (having won the tournament five times), but its entertaining style of football appeals to many. The country is also noted for producing football super stars with a large numbers of admirers such as the legendary Pele (considered by many as the greatest footballer ever), Ronaldo (who holds 
the record of being the second highest goal scorer in the history of the FIFA World Cup), Ronaldinho (the epitome of dribbling skills), and Neymar (who made a considerable impression at the 2013 FIFA Confederations Cup and the 2014 FIFA World Cup). The awarding of the hosting rights of the FIFA 2014 World Cup and the 2016 Olympic Games to Brazil demonstrates the country's status as an emerging power in the twenty-first century. The successful hosting of these events resulted in instant global visibility and showcased the Brazilian culture to the world.

The Samba (a popular Brazilian music and dance) and the Carnival are Brazil's cultural symbols that have significant appeal to the outside world, demonstrated by the number of foreigners that visit the country for the annual carnival particularly in cities like Rio de Janeiro, Sao Paulo, and Salvador. The Carnival is widely regarded as one of the most popular annual cultural celebrations in the world. Rio de Janeiro alone attracted more than 1.1 million tourists to the 2017 Carnival, boosting the city's economy by around $\mathrm{R} \$ 3$ billion (The Rio Times, 2017). The 2018 Carnival attracted 10.69 million Brazilian and 400,000 international tourists (an increase of 0.75 per cent compared with the previous year), boosting the economy by $\mathrm{R} \$ 11.14$ billion (The Rio Times, 2018).

Brazil's pacific and conciliatory posture influences the formulation and execution of its foreign policy. In its international relations, Brasilia holds the values of sovereignty and the peaceful resolution of disputes in high esteem. The country rarely uses its hard power currency to promote its national interests. For instance, despite its economic strength, it has not imposed sanctions on other states. Rather, it embraces cooperation in its international relations (Trinkunas, 2014). Brazil plays a major role in many international institutions. In the UN, it has been involved in peacekeeping missions in Angola, Cyprus, Lebanon, and Haiti. Within the World Trade Organisation (WTO), Brazil championed developing countries' opposition to the United States' and European countries' stances on global trade and it has also played a prominent role in climate change summits (Trinkunas, 2014). This has led to acceptance of its leadership in its region and it consequently plays a pivotal role in the region and the globe. Nye (2004) argues that foreign policy that appears to be inclusive, such as promoting peace and embracing multilateralism, boosts a state's soft power. Against this backdrop, Brazil's non-use of force in its international relations has shown the country in a positive light, especially among developing countries (Bertonha, 2010).

In comparison with other rising powers such as India and China, Brazil's recent regional security environment is enviably peaceful, at least at the interstate level:

This has diminished Brazil's interest in developing the kinds of military capabilities characteristic of other rising powers. Its history as a developing country has limited its willingness to accept the costs of using economic power through sanctions or aid to induce other states to change their behaviour. 
Brazil's positive global reputation can also be attributed to its political values. Its apparent consolidated democracy is the envy of other developing countries on the path to democratic consolidation. Among the BRICS countries, only Brazil, South Africa, and India are democracies. Brazil's relatively thriving economy, coupled with a strong state and some level of social inclusion, is admired by developing countries and the developed countries also seek to promote these ideals across the developing world (Trinkunas, 2014). Thus, Brazil's relative success in the political and economic realms provides a model for its region. Other South American countries may emulate Brazil's political and economic arrangements following the regional hegemon's impressive performance in these spheres. However, the Dilma Rousseff presidency squandered Brazil's soft power as it was tainted by corruption scandals that resulted in Brazil's political and economic decline. This has been compounded by the emergence of far-right president Jair Bolsonaro, whose rhetoric undermines Brazil's image. For example, his posting of a pornographic image of the carnival in a Tweet attracted international condemnation (Ballerini, 2020) and his coronavirus denialism has resulted in Brazil's emergence as the country with the third highest number of coronavirus cases in the world (Yadav, 2020), lagging only behind the United States and India.

\section{Africanising soft power}

As noted earlier, some African realities are neglected in the conceptualisation of soft power; hence, the relevance of Africanising the concept. The African philosophies captured by South African Ubuntu, Nigerian Omolúwàbi, Kenyan Harambee, and Egypt's Pharaonism are germane in this regard. While these philosophies have their own unique national orientation, they (particularly Ubuntu, Omolúwàbi, and Harambee) share some commonality with regard to their emphasis on collectivism as opposed to individualism. This collective posture is in direct contrast with Western individualism. It is within this context that one can understand these philosophies as alternatives to Western primacy of individualism and the dominant realist theory of international relations. Against this background, these philosophies offer potential soft power resources that counteract the notion of individualism in a world that is increasingly yearning for collective action to respectively promote and tackle the positive and dark sides of globalisation.

\section{Ubuntu in South Africa}

Qobo and Nyathi (2016: 424) conceptualise Ubuntu as "a value-set that views the existence of an individual as deeply woven into a social structure founded on humanism and collectivist ways of being that are mostly associated with African social systems". Ubuntu is grounded in notions such as, "Your pain is My pain, My wealth is Your wealth, Your salvation is My salvation" (Nussbaum, 2003: 2). While it emphasises an individual's sense of oneness in a community, the individual needs to have moral worth that reflects their social standing in the 
community (Dauda, 2017). An "Individual can only say: I am because we are, and since we are, therefore I am" (Akinola and Okeke-Uzodike, 2018: 95). Ubuntu dictates that communities' survival is determined by communion and shared responsibilities, and power is exercised on the basis of consensus (Madise and Isike, 2020). The South African and by extension African understanding of personhood cannot only be described in terms of idiosyncratic traits but in relation to the community (Nussbaum, 2003).

While the dominance of the realist framework in international affairs has relegated Ubuntu principles to the backburner, the realities of today's world have demonstrated the relevance of this philosophy in international politics (Qobo and Nyathi, 2016). Because Ubuntu aims to promote the common good, it enhances peace and harmony as opposed to individualism, which is characterised by competition and thus has the potential to distort peace and security (Akinola and Okeke-Uzodike, 2018). Ubuntu thus presents an alternative paradigm to the realist international order characterised by power and self-interest, with the resultant effects of fear, mistrust, and real politik (Qobo and Nyathi, 2016).

Ubuntu is an integral part of South African culture that is embedded in values such as reciprocity, humanness, dignity, harmony, caring, sharing, compassion, and forgiveness in the community (Tella, 2017). The fact that this philosophy assumed prominence in the post-apartheid period is not surprising, given that the apartheid regime was condemned and isolated (Qobo and Nyathi, 2016). South Africa's Truth and Reconciliation Commission (TRG), which received global accolades, was grounded in the principles of Ubuntu, reflected in the amnesty granted to perpetrators who confessed to human rights abuses during the apartheid regime (Tella, 2017). Nussbaum (2003) demonstrates that South Africa's successful transition to democracy is attributable to the reconciliatory posture of black leaders like Nelson Mandela who worked to ensure consensus. Ubuntu is underlined by emancipatory notions such as non-racialism, non-sexism, and democracy, which directly conflict with the realities of the apartheid era (Qobo and Nyathi, 2016). It was critical in enabling post-apartheid South Africa to look beyond the bitterness and hatred of the past and embrace a political transition that fostered a "rainbow nation" (Akinola and Okeke-Uzodike, 2018). The success of the TRC highlights the potential importance of Ubuntu in conflict resolution in South Africa and further afield (Akinola and Okeke-Uzodike, 2018). The African National Congress (ANG) has a long history of international solidarity and the core of South African foreign policy, including human rights, peace building, and a just international order, is embedded in the Ubuntu philosophy (Qobo and Nyathi, 2016). This philosophy also finds expression in other Southern African states and other African countries' cultures more broadly (Ogunnubi and OkekeUzodike, 2015). Indeed, Ubuntu presents a veritable tool to address the various dimensions of conflicts that have engulfed Africa (Akinola and Okeke-Uzodike, 2018) from ethnic conflict to electoral violence, terrorism, and civil war.

In a sense, Ubuntu serves as a counter-ideology to the Western global hegemony in the epistemic, cultural, and economic spheres (Qobo and Nyathi, 2016). It thus presents an alternative ideology to liberal democracies where there seems 
to be a moral vacuum. In lieu of individualism, Ubuntu underscores the community. Western countries can draw inspiration from South Africa and Africa in general for the values of oneness, humanness, and community (Tella, 2017). It is against this backdrop that Nussbaum (2003: 2) argues that:

I am convinced that ubuntu could enrich the range of new paradigms emerging worldwide that are currently inspiring business, political and civic leaders to transform organizations. Finally the spirit of ubuntu, if taken seriously, could influence and change relationships between nations.

Ubuntu values reinforce a multilateral, multipolar, and interdependent international system as opposed to the current global pecking order (Qobo and Nyathi, 2016). It was in the spirit of Ubuntu that South Africa invited other African countries to participate in the BRICS summit it hosted in 2018, resulting in efforts to establish BRICS Plus that will comprise BRICS countries and African states (Madise and Isike, 2020). Madise and Isike further argue that "Ubuntu is essentially a soft power philosophy, resource, and agency that carries with it an alluring moral authority that permeates all sectors that form South Africa's and Africa's social fabric" (2020: 7).

A foreign policy grounded in Ubuntu would thus include policies to maximise, in a framework of multilateralism and ethical leadership, South Africa's economic prosperity for greater benefit domestically, as well as South Africa's voice in forums challenging global economic governance structures.

(Qobo and Nyathi, 2016: 433)

The significance South Africa attaches to Ubuntu in its international relations is perhaps best illustrated by the 2011 White Paper on South African foreign policy titled "Building a better world: The diplomacy of Ubuntu". The preamble to the White Paper notes that:

South Africa is a multifaceted, multicultural and multiracial country that embraces the concept of Ubuntu as a way of defining who we are and how we relate to others. The philosophy of Ubuntu means "humanity" and is reflected in the idea that we affirm our humanity when we affirm the humanity of others. It has played a major role in the forging of a South African national consciousness and in the process of its democratic transformation and nation-building.

(South African Government, 2011:4)

Therefore, Ubuntu has the potential to present a framework for South Africa's behaviour in international affairs in the arena of politics, diplomacy, and the economy (Qobo and Nyathi, 2016). Nussbaum (2003: 6) poses several key questions: 
At this moment in our history, I cannot help wondering what the world would look like if other leaders took a leaf out of this remarkable man's [Mandela] book. What would capitalism look like if infused with "ubuntu?" What would the World's economic order look like? What would the legal system look like in America? What would the world be like if all oppressors apologized for their wrongdoings and then committed themselves to healing and helping members of their local communities and global family with appropriate restitution? Imagine the energy released by their reclaimed humanity? How much more heartfelt economic and political generosity might there be?

South Africa's celebrated 1996 constitution, which is regarded as one of the most progressive in the world, is grounded in Ubuntu as is evident in its embrace of reparation rather than retaliation and Ubuntu in lieu of victimisation (Akinola and Okeke-Uzodike, 2018).

\section{Omolúwàbí in Nigeria}

The Omolúwàbi (personhood or the epitome of good character) philosophy, embraced by Yoruba communities in Nigeria, presents important traditional African codes that could offer lessons for governance in Africa and further afield (Dauda, 2017). Omolúwàbi is an ideal that everyone is expected to strive for in order to have a sense of belonging in the Yoruba community (Oripeloye and Omigbule, 2019). Omolúwàbi has normative and descriptive dimensions. While as a descriptive concept it connotes an individual that has attained a moral status of the epitome of good character which is recognised in the community; as a normative one, it sets the standard for acceptable behaviour in the community (Dauda, 2017). The philosophy represents indigenous moral codes that offer potential lessons for African humanism and ethical governance grounded in democracy, equity, and moral responsiveness (Oripeloye and Omigbule, 2019). It encapsulates the need to uphold dignity and serve the community (Rombo and Lutomia, 2016). Like the Bantu in South Africa, Yoruba society is a communal one in which the line between an individual and the community is blurred in the socio-economic and political spheres (Dauda, 2017). A person's morality, which is considered as an important criterion of personhood, is determined by the content of their character which is measured against the codes of behaviour in all spheres of life (Ojo, 2019). The values of Omolúwàbi include truthfulness, integrity, modesty, courage, adherence to rules, self-discipline, self-control, self-reliance, social responsibility, tolerance, selfless service to humanity, loyalty to traditions, honesty in public and private dealings, diligence, and probity (Dauda, 2017; Ojo, 2019). Onifade (n.d.) outlines the attributes of Omolúwàbi as follows:

- Combines expertise in some specific economic skills with soundness of character and skills, and wisdom in judgment;

- Is equipped to successfully handle the problems of living in his/her immediate and extended family; 
- Very well versed in the folklores and genealogies of his/her ancestors;

- Possesses practical skills to handle some minor health problems and knows where to obtain advice and help in major ones;

- One who stands well with the ancestral spirits of the family; knows how to observe their worship; and

- Is endowed with the ability to discharge his/her social and political duties.

Against this background, Omolúwàbi can be argued to be an ideal individual who is worthy of emulation. The notion is, if all individuals in society were to embrace the ethos of Omolúwàbi, we would have a better society and a better world. Omolúwàbi thus provides an alternative paradigm to international politics which is characterised by power politics and the attendant promotion of a state's narrow interests as opposed to the common good. From a realist standpoint, there is no morality in international politics. Omolúwàbi, on the other hand, emphasises the centrality of morality in creating a better society and by extension a better world. The philosophy also offers a more democratic society than Western democracy. In the West, the emphasis is on the protection of individual and property rights; Omolúwàbi further guarantees equal access to economic, social, and political resources (Dauda, 2017). It could also serve as inspiration in the fight against bad leadership and corruption across Africa.

Its significance to conflict resolution stems from the fact that settlements are reached by appealing to the Omolúwàbi (conscience) of the parties in conflict (Johnson, 2016). Omolúwàbi dictates that the adults in the community are responsible for a child's socialisation, the land belongs to the community, and decisions are only arrived at after consultation and negotiation (Dauda, 2017).

The notion of timely death of an Omolúwàbi signifies dying after achieving core values such as: having children that continue one's legacy; leaving behind instruments of value including farmland, a house, and clothes; being known as a responsible member of a family and community; upholding the truth; leaving behind a good name; being known for touching the lives of others in the community; and holding an important position in the community (Oripeloye and Omigbule, 2019). In a nutshell, the philosophy of Omolúwäbi frowns on unacceptable behaviours and encourages societal virtues. It thus offers important lessons in the areas of diplomacy, governance, conflict resolution, and inter-state relations.

\section{Harambee in Kenya}

Harambee, the national motto of Kenya, was popularised by the country's first post-independence President, Jomo Kenyatta, who ended most of his speeches with the term which received wide approval among Kenyans (Chetty, 2009). Kenyatta first used the term on 1 June 1963 during a celebration of the country's Independence Day. He declared: 
As we participate in pomp and circumstance, and as we make merry this time, remember this: we are relaxing before the toil that is to come. We must work harder to fight our enemies that are ignorance, sickness and poverty. I therefore give you the call HARAMBEE! Let us all work hard together for our country Kenya.

(Murage, 2007: 20)

This use of the concept as a call to action changed Kenya's national philosophy from Uhuru (freedom), which characterised the colonial period, to Harambee (let us all pull together) in the post-independence period. Harambee "is collective and cooperative participation by a community in an attempt to resolve perceived needs through utilization of its own resources" (Orora and Spiegel, 1980: 244).

In 2010, Kenya's third President, Mwai Kibaki, reiterated the spirit of Harambee, by encouraging Kenyans to:

embrace a new national spirit; a spirit of national inclusiveness, tolerance, harmony and unity [...] to build a nation that will be socially and economically inclusive and cohesive where all have equal access and opportunities to realize their full potential.

(The Equal Rights Trust, 2012: 1)

Harambee projects are often self-help activities directed at the construction of public utilities (which the government is constrained to provide), thereby alleviating poverty and work overload and providing public goods such as health and education (Chepkwony, 2008). Harambee projects usually entail five stages: initiation, planning, fund-raising, implementation, and follow up (Murage, 2007). Using self-help methods to raise resources (with each individual contributing according to their ability), local communities have established health centres, roads, schools, dams, community buildings, and bridges (Godfrey and Mutiso, 1975) in the spirit of Harambee.

Thanks to the charisma of Jomo Kenyatta, the Harambee spirit spread like wildfire across the country, evident in various voluntary community self-help projects to establish schools and health centres, and communal digging of ditches for water pipes (Orora and Spiegel, 1980). In light of Kenyans' remarkable commitment to Harambee projects, Mbithi (1972: 149) asked:

What persuades and sustains such people to keep contributing the hard earned shilling after shilling, song after song, sweat drop after sweat drop to build public roads, cattle dips, schools, health centres, community buildings, youth centres, fish ponds, and bridges?

While it was popularised by the former president, Harambee was not a new concept as the philosophy was visible in indigenous Kenyan communities under different names such as Kip-agenge in the Kalenjin community, Ngwatio in Kikuyu, and Konyir in the Luo community (Chepkwony, 2008). For instance, in order to 
counteract the potential negative impact of colonial education on indigenous cultures and traditions, various communities adopted the Harambee spirit to construct schools (Murage, 2007).

Harambee underscores four key principles:

- A bottom-up development strategy where people at the community and grassroots level participate actively in the planning and implementation of local development projects.

- Participation is guided by the principles of collective good rather than individual gain. The end product thus benefits the public rather than only an individual.

- The choice of the project is guided by the felt needs of the majority instead of leaving the task to the government and other change agents whose priorities in terms of project selection may not be those of the people, the ultimate beneficiaries.

- Project implementation should maximise the utilisation of local resources such as labour, funds and materials which would otherwise not have been mobilised, or would be expensive.

(Chieni, 1998: 2-3)

In a nutshell, Harambee motivates Kenyans to give their all in any tasks for the good and development of the community. It encompasses values such as mutual social responsibility, a joint effort, and community self-reliance. Ownership of development thus lies in the hands of the public as the Kenyan people, NGOs, and government work together to expedite development (Chieni, 1998). Such collaborative efforts were emphasised in Jomo Kenyatta's speech during the state opening of parliament on 13 December 1963:

Our motto "harambee" was conceived in the realisation of the challenge of national building that now lies ahead of us. It was conceived in the knowledge that to meet this challenge, the government and the people of Kenya must pull together. We know only out of our efforts and toil can we build a new and better Kenya. This then is our resolution.

(Murage, 2007: 21)

Clearly, Harambee is Kenya's national motto, a symbol of its culture that is inscribed in the country's currency and Coat of Arms, and the headquarters of government departments in Nairobi. While in recent times the philosophy has been used to promote political corruption, the values of Harambee serve as an important soft power resource in an era when Africa has realised the need to own its development initiatives. In a bid to provide African solutions to African challenges, the continent and by extension the world can draw veritable lessons from Kenya's Harambee philosophy. Harambee also offers potential lessons in the arena of governments' collaborative efforts with NGOs and the public towards the development of a state. It also reveals the success that can be achieved through community self-help systems in situations where the state is either incapacitated 
or unable to render specific public goods. These are important lessons for citizens across the world that often rely heavily on their governments for the provision of social amenities.

\section{Pharaonism in Egypt}

Foreign domination of Egypt provides a unique experience in Africa. From $525 \mathrm{BC}$, when the African country was conquered by the Persians, it was ruled by the Macedonians under Alexander, the Romans under Julius Caesar, the Arabs in the seventh century, the Turks in the sixteenth century, and Napoleon's France, as well as the English in the nineteenth century (Diop, 1970). This begs the question as to what attracted these different colonial powers to the African country in what Nye (2004) describes as negative attraction (attraction that leads to domination)? As Diop (1970: 19) notes, Egypt was the "cradle of civilization for ten thousand years, while the rest of the world wallowed in barbarism". Pharaonism has been adopted as an epistemological standpoint to debunk the Western hegemonic notion of Egyptian history and to offer a political and legal framework for Egyptian decolonisation (Lietzelman, 2014-2015).

Pharaonism reclaimed the iconography that the West had used to reduce Egypt to a Neolithic wonder overrun by backward Ottomans incapable of admiring their own history, and then it employed this iconography to demonstrate the ancient indigeneity and rightfulness of Egyptian independence.

(Lietzelman, 2014-2015: 51)

Colla's (2007: 274) articulation of Pharaonism is worthy of extensive quotation. Colla notes that Pharaonism:

created powerful narratives and images of Egyptian national identity, one in which individual and communal identity were interchangeable: an identity that was historical and also transcendent; an essence that had its own natural style of artistic expression; a springboard for political action that was based in the present moment of Egypt's colonial subjection and in a past moment of Egyptian colonial might. Pharaonism addressed Egyptians as individual citizens of a modern nation and also as members of a collective that was timeless. It appealed to hearts no less than minds. The flexibility of these claims made Pharaonism a potentially powerful discourse.

Egyptian civilisation and Pharaonism attract foreign tourists (including those that would ordinarily not visit museums of natural history and fine art) across the world who flock to the country's museums such as the Egyptian Antiquities Museum and Museum of Islamic Art (Riggs, 2013). These museums elegantly showcase the pharaonic past, leaving visitors bewildered. In the West's 
imagination, the pharaonic past is reinforced by the Bible and classical authors. Riggs (2013: 68) asserts that:

its historical longevity, cultural accomplishments, and enduring materiality (pyramids, hieroglyphs, mummies) helped mark ancient Egypt as a "civilisation" ripe for appropriation and worthy of inclusion in universalist narratives, including institutions like the Louvre, the British Museum, and the Metropolitan Museum of Art.

Pharaonism was an Egyptian cultural and political movement, which was popular in the 1920s. It underlined Egyptian exceptionalism in relation to other Middle Eastern and Arab states (Miccoli, 2016). The movement underscores Egypt's distinctive national identity that is evident in the Arab country's ancient past and legacy (Miccoli, 2016). Pharaonism's emphasis on Egyptian nationalism has facilitated reconciliation across class, regions, and sects (Colla, 2007). The philosophy has shaped Egypt's foreign policy to date. For example, Pan-Arabism championed by former Egyptian President Gamal Abdel Nasser was underlined by Egyptian nationalism as the country was portrayed as the oldest, premier, and most precious Arab nation (Langer, 2017). The ideological foundation of Pharaonism is distinct from other ideologies in that Pharaonism is underlined by the images of territory and civilisation, offering both concrete and abstract dimensions demonstrated by the ubiquitous monuments across the country (Colla, 2007).

The numerous foreign interventions led to Egypt's political decline. However, Egyptian civilisation remained the template for the civilisations of other Mediterranean nations, including Greece and Rome, which benefitted from their strategic location at the crossroads of the world (Diop, 1970). No other nation's civilisation was superior to Egypt's and other nations saw Egypt as a model in the areas of legislation, civil justice, and the sciences. The country excelled in science and engineering, as well as military and political capabilities (Colla, 2007).

Although it enjoyed advantageous economic conditions, like other African nations, Egypt chose to focus on developing political, social, and moral structures rather than advancement in science and technology. For example, while the Egyptian priests knew the secret of gunpowder, it was only used in religious rites (Diop, 1970). However, there were exceptions in order to meet domestic needs, such as the invention of geometry designed to prevent flooding from the Nile and a calendar which involved the calculations of thousands of years of previous development (Diop, 1970). The focus on political and social structures rendered African political organisation equal and in some instances superior to their European counterparts in the fifteenth century when European countries such as Portugal, Netherlands, England, and France began to establish trading posts on the west coast of Africa (Diop, 1970). It is now increasingly acknowledged even by European scholars that the origins of Western civilisation lay in Egyptian civilisation (Colla, 2007). 


\section{References}

Akinola, A. and Okeke-Uzodike, U. (2018). "Ubuntu and the Quest for Conflict Resolution in Africa." Journal of Black Studies 49 (2): 91-113.

Ballerini, F. (2020). Is Brazil's Soft Power Under Threat? Fair Observer, 21 February. https: //www.fairobserver.com/region/latin_america/brazil-football-carnival-culture-soft-pow er-jair-bolsonaro-news-15521/.

Bertonha, J. (2010). "Brazil: An Emerging Military Power? The Problem of the Use of Force in Brazilian International Relations in the 21st Century." Rev. Bras. Polit. Int. 53 (2): 107-124.

Blarel, N. (2012). India: The Next Superpower? India's Soft Power: From Potential to Reality? IDEAS reports - special reports LSE IDEAS. London: London School of Economics and Political Science.

Carr, H. E. (1946). The Twenty Tears' Crisis, 1919-1939: An Introduction to the Study of International Relations. New York: Harper and Row.

Chepkwony, K. (2008). The Role of Harambee in Socio-Economic Development in Kenya: A Case of the Education Sector. Investment Climate and Business Environment Research Fund. Report No. 16/12.

Chetty, D. (2009). "An Harambee Theory of Rhetoric in Social Action: Persuasion, Religious Identity \& Recognition in Sudan.” Alternation 16 (Special Edition): 301-330.

Chieni, S. (1998). The Harambee Movement in Kenya: The Role Played by Kenyans and the Government in the Provision of Education and other Social Services. Moi University.

China Power (2017). "Is China Both a Source and Hub for International Students?" China Power. 26 September. https://chinapower.csis.org/china-international-students/.

Cho, Y. and Jeong, J. (2008). "China's Soft Power: Discussions, Resources, and Prospects." Asian Survey 48 (3): 453-472.

Colla, E. (2007). Egyptology, Egyptomania, Egyptian Modernity. Durham and London: Duke University Press.

Council on Foreign Relations (2018). "China's Big Bet on Soft Power." https://www.cfr. org/backgrounder/chinas-big-bet-soft-power.

Ćwiek-Karpowicz, J. (2012). "Limits to Russian Soft Power in the Post-Soviet Area." DGA Panalyse 8.

Dauda, B. (2017). "African Humanism and Ethics: The Cases of Ubuntu and Omolúwàbí” In: Afolaya, A., and Falola, T. (eds), The Palgrave Handbook of African Philosophy. London: Palgrave, pp. 475-492.

De Lima, M. and Hirst, M. (2006). "Brazil as an Intermediate State and Regional Power: Action, Choice and Responsibilities." International Affairs 82 (1): 21-40.

Ding, S. (2010). "Analyzing Rising Power from the Perspective of Soft Power: a new look at China's rise to the status quo power." Journal of Contemporary China 19 (64): $255-272$.

Diop, C. (1970). "The Birth of the 'Negro Myth" In: Markovitz, I., and Markovitz, R. (eds), African Politics and Society: Basic Issues and Problems of Government and Development. New York: Free Press.

Ferguson, N. (2009). "Think Again: Power." Foreign Policy, 3 November. https://foreignp olicy.com/2009/11/03/think-again-power/.

Gallup (2010). “Americans See Slight Improvement in U.S. Global Image.” https://news. gallup.com/poll/125858/americans-slight-improvement-global-image.aspx.

Gill, B. and Huang, Y. (2006). "Sources and Limits of Chinese Soft Power." Survival: Global Politics and Strategy 48 (2): 17-36. 
Godfrey, M. and Mutiso, G. (1975). "Economics, Politics and Education: Kenya's Harambee Institutes of Technology." Institute of Development Studies Bulletin 6 (3): 85-94. Gramsci, A. (1971). Selections from the Prison Notebooks. London: Lawrence and Wishart.

Hill, F. (2006). "Moscow Discovers Soft Power." Current History 105 (693): 341-347.

Huang, Y. and Ding, S. (2006). "Dragon's Underbelly: An Analysis of China's Soft Power." East Asia 23 (4): 22-44.

Indian Council for Cultural Relations (2019). "List of ICGR Operational Chairs." http s://www.iccr.gov.in/online-form/chairs/introduction.

Jaishankar, D. (2018). "India Rising: Soft Power and the World's Largest Democracy." https://www.brookings.edu/opinions/india-rising-soft-power-and-the-worlds-largest-de mocracy/.

Johnson, I. (2016). "Beyond Orthodox Strategies: Managing Conflicts and Sustaining Peace through Communal Ethics, Traditional Values and Methods in Africa." Studies in Sociology of Science 7 (4): 26-33.

Kurlantzick, J. (2007). Charm Offensive: How China's Soft Power Is Transforming the World. New Haven and London: Yale University Press.

Langer, C. (2017). "The Informal Colonialism of Egyptology: From the French Expedition to the Security State." In: Woons, M. and Weier, S. (eds), Critical Epistemologies of Global Politics. Bristol: E-International Relations Publishing, pp. 182-202.

Laruelle, M. (2015). The "Russian World" Russia's Soft Power and Geopolitical Imagination. Washington, DC: Centre on Global Interests.

Lietzelman, H. (2014-2015). "Pharaonism: Decolonizing Historical Identity." Prized Writing (46-51).

Madise, D. and Isike, C. (2020). "Ubuntu Diplomacy: Broadening Soft Power in an African Context." Journal of Public Affairs. https://doi.org/10.1002/pa.2097.

Mbithi, P. (1972). "Harambee' Self-Help: The Kenyan Approach.” African Review 2 (1): 147-166.

Miccoli, D. (2016). "A Fragile Cradle: Writing Jewishness, Nationhood, and Modernity in Cairo, 1920-1940.” Jewish Social Studies: History, Culture, Society 21 (3): 1-30.

Murage, J. (2007). "Harambee as an Indigenous Lived Philosophy: Empowering the Poor in the Kenyan Anglican Church.” Submitted in partial fulfilment of Masters of Theology (Theology and Development), in the School of Theology and Religion, Faculty of Human Sciences and Management at the University of KwaZulu-Natal, Pietermaritzburg, South Africa.

Nussbaum, B. (2003). "African Culture and Ubuntu: Reflections of a South African in America." Perspectives 17 (1): 1-12.

Nye, J. (1990). Bound to Lead: The Changing Nature of American Power. New York: Basic Books. Nye, J. (2004). Soft Power: The Means to Success in World Politics. New York: Public Affairs.

Nye, J. (2009). "Get Smart: Combining Hard and Soft Power." Foreign Affairs 88 (4): 160-163.

Nye, J. (2011). The Future of Power. New York: Public Affairs.

Ogunnubi, O. and Okeke-Uzodike, U. (2015). "South Africa's Foreign Policy and the Strategy of Soft Power." South African Fournal of International Affairs 22 (1): 23-41.

Ojo, O. (2019). "Cultural Renaissance and the Quest for Peace and Development in Nigeria." Fournal of International and Global Studies 10 (2): 86-102.

Onifade, Temitayo Abayomi (n.d.). "Omoluabi: Perspectives to Value and Character in Traditional Yoruba Societies." https://www.Academia.Edu/17302435/Omoluabi_ Perspectives_To_VAlue_And_Character_In_Traditional_Yoruba_Societies.

Oripeloye, H. and Omigbule, M. (2019). "The Yoruba of Nigeria and the Ontology of Death and Burial." In: Selin, H. and Rakoff, R. (eds), Death Across Cultures, Science Across Cultures: The History of Non-Western Science. Cham: Springer, pp. 193-205. 
Orora, J. and Spiegel, H. (1980). "Harambee: Self-Help Development Projects in Kenya." International Fournal of Comparative Sociology 21 (3/4): 243-253.

Pew Research Centre (2008). "Global Public Opinion in the Bush Years (2001-2008): America's Image; Muslims and Westerners; Global Economy; Rise of China." https:// www.pewresearch.org/global/2008/12/18/global-public-opinion-in-the-bush-years-200 $1-2008 /$.

Popescu, N. (2006). Russia's Soft Power Ambitions. CEPS Policy Briefs issue, 112. London: Centre for European Studies.

Purushothaman, U. (2010). "Shifting Perceptions of Power: Soft Power and India's Foreign Policy.” Fournal of Peace Studies 17 (2/3).

Qobo, M. and Nyathi, N. (2016) "Ubuntu, Public Policy Ethics and Tensions in South Africa's Foreign Policy." South African Fournal of International Affairs 23 (4): 421-436.

Ramo, J. (2004). The Beïing Consensus. London: The Foreign Policy Centre.

Riggs, C. (2013). "Colonial Visions: Egyptian Antiquities and Contested Histories in the Cairo Museum." Museum Worlds: Advances in Research 1 (1): 65-84.

Rombo, D. and Lutomia, A. (2016). “This Is America': Narratives of Parenting Experiences by African Immigrant Parents from Cameroon, Kenya, and Somalia Living in the United States". Transnational Social Review, 6 (1/2): 141-159.

Seymour, M. (2020). "The Problem with Soft Power." 14 November. Foreign Policy Research Institute. https://www.fpri.org/article/2020/09/the-problem-with-soft-power/.

Shambaugh, D. (2015). "China's Soft-Power Push: The Search for Respect." Foreign Affairs 94 (4): 99-107.

South African Government (2011). "White Paper on South African Foreign Policy Building a Better World: The Diplomacy of Ubuntu." https://www.gov.za/docum ents/white-paper-south-african-foreign-policy-building-better-world-diplomacy-ubuntu.

Tella, O. (2016). "A Declining or Stable Image? An Assessment of the United States' Soft Power in Africa." South African Fournal of International Affairs 23 (2): 151-166.

Tella, O. (2017). "South Africa in BRICS: The Regional Power's Soft Power and Soft Balancing." Politikon 44 (3): 387-403.

Tella, O. (2019). South Africa and the Great Powers on the United Nations Security Council. Johannesburg: Institute for Pan-African Thought and Conversation, University of Johannesburg.

The Equal Rights Trust (2012). In the Spirit of Harambee: Addressing Discrimination and Inequality in Kenya. ERT Country Report Series: London. https://www.equalrightstrust.org/sp irit-harambee-addressing-discrimination-and-inequality-kenya.

The Moscow Times (2019). "Russia's FSB Publishes Foreign Worker Statistics for First Time in 20 Years." 16 August. https://www.themoscowtimes.com/2019/08/16/russias-fsb-p ublishes-foreign-worker-statistics-for-first-time-in-20-years-a66895.

The Rio Times (2017). "Brazil Reports Surge in 2017 Carnival Tourism Attendance." http s://riotimesonline.com/brazil-news/rio-business/brazil-registers-surge-in-2017-carnival -attendance/.

The Rio Times (2018). "Carnival 2018 to Inject $\mathrm{R} \$ 11.14$ Billion into Brazil's Economy." 16 January. https://riotimesonline.com/brazil-news/rio-business/brazils-carnival-to-injectr11-14-billion-into-economy/.

Thussu, D. (2014). De-Americanizing Soft Power Discourse?Los Angeles: Figueroa Press.

Tourangbam, M. (2020). "India's Rise and Why Soft Power Matters." https://diplomatist. com/2020/08/25/indias-rise-and-why-soft-power-matters/.

Trinkunas, H. (2014). Brazil's Rise: Seeking Influence on Global Governance. Brookings: Latin America Initiative Foreign Policy. 
Tsygankov, A. (2006). "If Not By Tanks, Then By Banks? The Role of Soft Power in Putin's Foreign Policy.” Europe-Asia Studies 58 (7): 1079-1099.

Wagner, C. (2012). Emerging Powers in Regional Architecture. Asia Division German Institute for International and Security Affairs Working Paper FG 7. Berlin: German Institute for International and Security Affairs.

Xinbo, W. (2010). "Understanding the Geopolitical Implications of the Global Financial Crisis." The Washington Quarterly 33 (4): 155-163.

Yadav, N. (2020). "These Are the 10 Most-affected Countries with the Highest Number of COVID-19 Cases." Business Insider, 27 October. https://www.businessinsider.in/poli tics/india/news/check-out-the-10-most-affected-countries-with-the-highest-number-of-c oronavirus-cases/slidelist/76275918.cms.

Zhao, S. (2010). "The China Model: Can It Replace the Western Model of Modernization?” Journal of Contemporary China 19 (65): 419-436. 


\title{
3 Nigeria
}

\author{
Naija swagger ${ }^{1}$
}

\section{Introduction}

Nigeria's capacity to determine issues of sub-regional and to a lesser extent continental consequence cannot be denied, despite the state's challenges. An important subject of inquiry is the key resources Abuja deploys to achieve its foreign policy objectives in its engagement with its regional counterparts and external actors. Nigeria is renowned for its hard power resources, especially its economic and military might as the largest economy in Africa and Abuja's role as a major peacekeeper on the continent, respectively. Beyond the obvious hard power resources, Nigeria enjoys some soft power currencies such as: its philosophy of Omolúwàbi; cultural sources including Nollywood, Nigerian music (Afrobeats), multinational corporations, mega churches, the diaspora, and its fashion industry; its foreign policy of democracy promotion, peace diplomacy, and aid; and its multilateral foreign policy and role in international organisations.

Indeed, Nigeria has deployed these soft power resources in pursuit of its foreign policy objectives ranging from decolonisation to peacemaking, economic diplomacy, cultural diplomacy, technical aid, democracy promotion, African integration, and broader Pan-African issues. For example, Nollywood, Afrobeats, and the country's multinational corporations have been critical to the success of Nigeria's cultural and economic diplomacy. Abuja's democracy promotion in states such as São Tomé and Príncipe, Sierra Leone, Liberia, and the Gambia, coupled with its peace diplomacy in conflict zones like Liberia and Sierra Leone and its philosophy of Omolíwàbi that presents an alternative world view, are indicative of how Abuja has exercised its soft power and the potential of the sources that have not been utilised. Nevertheless, there seems to be a wide gap between Nigeria's soft power resources and its influence in international affairs. This is partly the result of a number of challenges that undermine the state's capacity to effectively wield its power of attraction. The constraints include a democracy deficit, illicit activities, Boko Haram terrorism, and the great power's influence in Africa. These limitations have combined in many ways to engender anti-Nigerian sentiment and an image crisis, which have manifested in dehumanisation, deportation, and killing of Nigerians across the globe.

DOI: $10.4324 / 9781003176022-3$ 
To effectively wield its soft power, Nigeria thus needs to address ongoing antiNigerian sentiment and its image problem. Re-inventing Nollywood, tackling the democracy deficit, and taking citizen diplomacy more seriously could well be the catalyst required to make Nigeria more attractive in order to be able to play its part as an effective hegemon in Africa.

\section{Nigeria's soft power currencies}

\section{Global Nollywood and Afrobeats}

\section{Nollywood}

After what is widely considered to be the first Nollywood movie Living in Bondage was released in 1992, and since 2002 when the term "Nollywood" was coined by New York Times journalist, Norimitsu Onishi, the Nigerian film industry has become a global phenomenon. Nollywood produces around 2,500 movies annually, has more than 30 million followers across the world, and generates about $\$ 600$ million each year, with revenue from cinema estimated to reach $\$ 22$ million by 2021. The movie industry employs more than a million Nigerians (second only to agriculture), contributing significantly to the country's economy (Oh, 2014; PricewaterhouseCoopers, 2017a).

There is no gainsaying that the Nigerian movie industry has become a global phenomenon having overtaken Hollywood and only behind Bollywood in terms of global output. It has an undisputable influence in Africa and beyond including faraway places such as the United States, the United Kingdom (UK), Canada, and the Caribbean, and to a lesser extent in Spain, Italy, and Germany (Miller, 2012). In the UK alone, BEN-TV, OBE-TV, and Passion TV screen Nollywood movies (Miller, 2012) and in China, the ST Nollywood Plus channel streams its films (McBain, 2019). Nigerian-owned online platforms including iROKOtv and Afrinolly have enhanced the online presence of Nollywood films. iROKOtv has the largest online catalogue of these films, with viewers in 178 countries across the globe (Jewell, 2019). In Africa, Nollywood has eclipsed Hollywood, Bollywood, and other African movie industries as many Africans consume the Nollywood movies screened across Africa by the South African cable television (DStv) that has four dedicated channels for these movies. Its success in relation to Hollywood and Bollywood stems from the fact that its audience can relate to the African realities including values, customs, tradition, and everyday life evinced in these movies as against Hollywood and Bollywood that depict Western and Indian circumstances, respectively.

The film industry provides an avenue to spread Nigerian cultural values across the world. It also serves as a channel to realise significant export earnings. The recalculation of Nigeria's Gross Domestic Product (GDP) in 2014 not only resulted in its economy being rated the largest on the continent, but also revealed the significance of the earnings of the service industry, particularly Nollywood, that had been neglected over the years in the calibration of the 
economy. In a nutshell, Nollywood provides the soft power advantage of cultural and economic diplomacy. Given its potential to create more jobs and boost the Nigerian economy, the World Bank and some private investors are assisting the country to combat piracy that has constrained the realisation of the industry's full potential (Oh, 2014). While the films are sold across Africa, the Caribbean, North America, Europe, and Asia, nearly all the exports are pirated copies. The World Bank estimates that nine out of ten copies sold are pirated and the Nigerian Copyright Commission calculates that more than $\$ 1$ billion is lost to piracy each year (Oh, 2014). The Nigerian government, the World Bank, and the private sector have provided financial support to enable the industry to realise its full potential. Table 3.1 shows some of the key funding Nollywood received between 2010 and 2013.

The funding from these different entities reflects the growth and influence of the film industry globally. The arts, entertainment, and recreation sector (which is dominated by Nollywood) contributed 239 billion Naira, 2.3 per cent of Nigeria's GDP in 2016 and Nollywood was part of the sectors targeted in the country's Economic Recovery and Growth plan that aimed to accrue $\$ 1$ billion in export revenue by 2020 (PricewaterhouseCoopers, 2017b).

In 2020, Netflix announced its arrival in Nigeria by launching Netflix Naija. Prior to the launch, Netflix had acquired some Nollywood films including Genevieve Nnaji's Lionheart in 2018, Kunle Afolayan's October 1st, and Biyi Bandele's Fifty in 2015 (McBain, 2019). These films are available to some of Netflix's over 200 million subscribers across the globe. Alongside Afrobeats, Nollywood provides Pan-African entertainment, prompting many observers to speak of the "Nigerianization" of African pop culture (Krings and Simmert, 2020). While Africa was once a major importer of global pop culture, thanks to Nollywood and Afrobeats, the continent has emerged as an important exporter (Krings and Simmert, 2020), reinforcing Nigeria's soft power. Indeed, Nollywood has displaced Hollywood, Bollywood, and local content on the continent. In East Africa, it has inspired film production in Kenya, Tanzania, and Uganda (Krings and Simmert, 2020). In West and Central Africa, Nollywood enjoys hegemony in places like Ghana, Togo, Cameroon, and the Democratic Republic of Congo (DRC). The growing Ghanaian industry has been stymied due to the influence of Nollywood in the country. In Southern Africa, it is very popular in states like South Africa, Zambia, and Zimbabwe. More generally, Nollywood has influenced the dress of Kenyan politicians and Congolese pastors, and the accents of some South African students, as well as hair stylists in the DRC, South Africa, Mozambique, and Zimbabwe (Adebajo, 2017; Onishi, 2016) and fashion designers across Africa and the diaspora. Former US Ambassador to Nigeria, John Campbell, stated that:

Nigeria's culture rooted in fashion, film, music, and literature translates into enhanced international prestige. At the time of independence, many hoped that as a huge, democratic country, Nigeria would provide Africa with a "seat at the table" among the traditional international powers. Perhaps that 
Table 3.1 Grants received by Nollywood

\begin{tabular}{|c|c|c|}
\hline Funder & Funds & Project \\
\hline World Bank & $\$ 20$ million & $\begin{array}{l}\text { In 2010, the World Bank } \\
\text { identified Nollywood as a } \\
\text { leading non-oil sector and } \\
\text { included it as part of its } \\
\text { Growth and Employment } \\
\text { in States (GEMS) project. } \\
\text { As part of GEMS, the } \\
\text { industry received funds to } \\
\text { aid sector growth and } \\
\text { boost employment. }\end{array}$ \\
\hline Nigerian Government & $\begin{array}{l}\$ 200 \text { million and } \$ 17-\$ 18 \\
\text { million }\end{array}$ & $\begin{array}{l}\text { In } 2011 \text {, Nigerian Pre- } \\
\text { sident Goodluck Jonathan } \\
\text { pledged a } \$ 200 \text { million } \\
\text { government loan for the } \\
\text { film industry, and in } \\
\text { March } 2013 \text {, announced a } \\
\$ 17-\$ 18 \text { million grant } \\
\text { called "Project ACT-Nol- } \\
\text { lywood" to back training } \\
\text { and skills acquisition for } \\
\text { film production and dis- } \\
\text { tribution. In addition to } \\
\text { federal initiatives, various } \\
\text { Nigerian state govern- } \\
\text { ments are supporting the } \\
\text { industry by funding } \\
\text { movies, award ceremonies, } \\
\text { and production villages. }\end{array}$ \\
\hline $\begin{array}{l}\text { Tiger Global Management } \\
\text { and Kinnevik }\end{array}$ & $\$ 8$ million & $\begin{array}{l}\text { In } 2011 / 12 \text {, US-based } \\
\text { hedge fund Tiger Global } \\
\text { Management (an early } \\
\text { Facebook investor), along } \\
\text { with Swedish investment } \\
\text { firm Kinnevik, backed } \\
\text { iROKOtv, the world's lar- } \\
\text { gest online distributor of } \\
\text { licensed Nollywood films. } \\
\text { Aspiring to be "Africa's } \\
\text { Netflix", iROKOtv spent } \\
\$ 5 \text { million of the initial } \\
\text { funds to amass the rights } \\
\text { to 5,000 Nollywood films. }\end{array}$ \\
\hline
\end{tabular}

Source: Oh (2014). 
is happening first with respect to art and culture, rather than by the more conventional political and security means.

(Campbell, 2018: para. 4)

In what Krings and Simmert (2020) have described as "the scramble for African media spaces", before Netflix's arrival, Eric Schmidt, former Chief Executive Officer of Google, visited Lagos in 2013, followed by Facebook's Mark Zuckerberg in 2016. It is within this context that one can locate the popular subscriptionbased television networks including South Africa's DStv, China's Star Times, and France's Canal Plus (Mail \& Guardian, 2019).

In light of anti-Nigerian sentiment across the globe, Nollywood is critical in debunking stereotypes. The media has the capacity to not only reinforce existing perceptions but also to set the agenda. On many levels, Nollywood has done so and has challenged negative narratives including drug and human trafficking, Internet fraud, and corruption. Perhaps the most important pointer to this is the interviews conducted across Africa by the British Broadcasting Corporation (BBC). The survey highlighted that Nollywood, alongside Afrobeats, accounts for much of the viewing time of many Cameroonians, Ghanaians, Liberians, South Africans, and Zambians (BBC News, 2010). It found that before Kenyans were exposed to Nollywood, aside from the works of literary heavyweights such as Chinua Achebe, Wole Soyinka, Elechi Amadi, and Chimamanda Adichie, they had negative perceptions of Nigeria as a result of the news they consumed on international media. Nollywood has changed these narratives as it provides the platform for Nigerians to tell their own stories (BBC News, 2010). Exposure to Nollywood has resulted in many Africans mimicking Nigerian pidgin English, fashion, and accent. This prompted Adebajo (2013) to assert that "Nollywood has expanded African culture across the continent and created an authentically panAfrican cinema". It sparked admiration for some of the top Nollywood stars including Genevieve Nnaji, Zack Orji, Kanayo O. Kanayo, Patience Ozokwor, Mercy Johnson, Ini Edo, Olu Jacobs, Funke Akindele, Pete Edochie, Mr Ibu, Chinedu Ikedieze and Osita Iheme (Aki and Pawpaw), as well as Jim Iyke, providing Nigeria with a reservoir of talent for celebrity diplomacy.

Admiration of Nigerian movies, music, fashion, and food has resulted in better understanding of the country's culture across the continent (Ogunnubi and Isike, 2018). Adebajo (2013) argues that Nollywood 'is a veritable source of 'soft power' that could be a cultural resource to challenge French artistic hegemony in Africa". Given France's influence in Africa, especially in the West African subregion, Nollywood's success in shaping African culture and values is important. The film industry presents an opportunity for Nigeria to exercise cultural hegemony on the continent and rise above its regional challengers like South Africa and Egypt and global competitors, including the United States, China, India, the UK, and France in this realm (Tella, 2017). Nollywood also needs to re-invent itself to become a source of public diplomacy by presenting Nigeria's economy and military capability and the state's contribution to the public good in Africa and further afield. This will enhance knowledge and understanding of Nigeria's role 
across the continent and beyond, which could ameliorate xenophobic and antiNigerian sentiment in South Africa, Africa and globally. A major constraint to Nollywood's influence is the industry's reliance on the South African multinational cable television (Dstv) to transmit its movies across Africa. This is certainly unsustainable. Thus, Nigeria needs to take advantage of its relative advancement in space technology to establish its own satellite-based cable television that will be able to transmit Nollywood movies across the continent. South Africa is Nigeria's hegemonic rival on the continent, and continual reliance on this state for Nigeria's soft power is untenable.

\section{Afrobeats}

It is estimated that revenue from Nigerian music will reach $\$ 73$ million by 2021 (PricewaterhouseCoopers, 2017a). Like Nollywood, the Nigerian music industry has been the dominant one in Africa. This is seen in the popularity of artists like Wizkid, Davido, Burna Boy, P Square, Tiwa Savage, Yemi Alade, Tekno, Flavour, and Olamide; and their songs such as Ojuelegba, Fall, On the Low, Personally, Ma Lo, Fohnny, Pana, Foro, $Y$ e, and Shakiti Bobo, which are admired and played on radio stations and in clubs across Africa and the Caribbean. It is for this reason that I argue elsewhere that, " $[\mathrm{g}]$ iven the ubiquity and admiration of Nigerian movies and music in Africa, African entertainment arguably wears a made in Nigeria label" (Tella, 2017: 111). Nigerian music artists dominated the MTV Africa Music Awards (MAMA) from the time they were launched in 2008 until they were halted in 2016. They have also dominated the Soundcity MVP Awards organised by Nigeria's Soundcity TV. In 2017, Wizkid outshone Drake, Jay-Z, and Kendrick Lamar to win the Music of Black Origin (MOBO) award for Best International Act, and Davido won Best African Act for If (Norbrook, 2020), a hit which now has more than 125 million views on YouTube. Davido won the Black Entertainment Television (BET) best international act in 2018 while Burna Boy won it in 2019 and 2020. In 2021, Burna Boy won a Grammy award in the category of Best Global Music Album for his album, Twice as Tall; while Wizkid won the Best Music Video for his collaboration with Beyoncé, Brown Skin Girl.Tables 3.2 and 3.3 show how Nigerian artists fared in the 2015 and 2016 MAMA Awards.

Table 3.2 2015 MAMA Awards

\begin{tabular}{ll}
\hline Award & Artist \\
\hline Best female & Yemi Alade \\
Best male & Davido \\
Best group & P Square \\
Best new act & Patoranking \\
Song of the year & Mavins (Dorobucc $)$ \\
MAMA evolution & D’banj \\
Artist of the decade & P Square \\
\hline
\end{tabular}

Source: author's adaptation from MTV Africa (2015). 
Table 3.3 2016 MAMA Awards

\begin{tabular}{ll}
\hline Award & Artist \\
\hline Best female & Yemi Alade \\
Best male & Wizkid \\
Artist of the year & Wizkid \\
Best breakthrough act & Tekno \\
Song of the year & Patoranking featuring Wande Coal (My Woman, My Everything) \\
Best collaboration & Wizkid, and South African DJ Maphorisa and DJ Bucks \\
& (Soweto Baby) \\
\hline
\end{tabular}

Source: author's adaptation from Okayafrica (2016).

Afrobeats has drawn international entertainment services including Deezer, iTunes, Shazam, Simfy, and YouTube to Nigeria (Ernst and Young, 2015). Beyoncé collaborated with Nigerian artists like Wizkid, Tiwa Savage, Mr Eazi, Yemi Alade, and Tekno on her companion album to The Lion King film (Norbrook, 2020). The country's top stars such as Burna Boy, Wizkid, Davido, Niniola, and Tiwa Savage are selling out concert venues like the Apollo Theatre, O2 arena, Skyway Theatre, Royal Albert Hall, and Le Trianon across major cities including New York, London, and Paris and are performing in major music festivals. Burna Boy performed at the Coachella Festival (one of the most popular music festivals in the world) in the United States in 2019. He and fellow Nigerian artist Mr Eazi were the first Africans to perform at the event, which had been held for 20 years, although Wizkid was invited in 2018 but could not attend due to visa issues (Giorgis, 2019). Burna Boy's reaction to Coachella promotional material is noteworthy. He stated on his Instagram page: "I really appreciate you, ... But I don't appreciate the way my name is written so small in your bill. I am an AFRICAN GIANT and will not be reduced to whatever that tiny writing means. Fix tings quick please" (Giorgis, 2019: para. 1). Following Coachella's lack of response, the artist's label designed and posted reimagined flyers with his name in the spaces for all the festival's invited artists. This is arguably a smart move that denotes that Africa and its people can now compete on the global stage and can no longer be treated like a backward continent and people. His performance at the festival was stunning and received global commendation.

Nigerian artists such as Burna Boy, Wizkid, Davido, and Tiwa Savage have collaborated with top American artists including Beyoncé, Chris Brown, Snoop Dog, Nicki Minaj, and Drake. These collaborations have put Nigerian music and artists on the global map. For example, D'Banj's song Oliver Twist, which included a cameo appearance by Kanye West, was the first Afrobeats to feature in the Top 10 in the UK Singles Chart in 2012; Drake's hit, One Dance, which featured Wizkid, popularised the Nigerian artist in North America especially the United States and Canada; and in 2016 and 2017, music labels Sony and Universal, the largest record companies, opened new franchises in Nigeria after having withdrawn from the country in the 1990s (Krings and Simmert, 2020). They have since signed artists 
such as Wizkid, Davido, Tiwa Savage, and Tekno, whose songs are released on streaming services like Apple Music and Spotify; giving these artists and their music and, by extension, Nigerian culture, global visibility. The growing influence of Afrobeats has resulted in artists across the globe - including American Beyoncé, French MHD, and other artists in places like Germany and Austria - drawing inspiration from Nigerian music (Krings and Simmert, 2020).

The Naïa swagger exhibited by both Nollywood and Afrobeats artists radiates further afield. Many popular black US and British artists are of Nigerian origin, including movie artists like Adewale Akinnuoye-Agbaje, Yvonne Orji, Chiwetel Ejiofor, David Oyelowo, Caroline Chikezie, Hakeem Kae-Kazim, Nonso Anozie, Richard Ayoade, Sophie Okonedo, Cynthia Erivo, and John Boyega, and musicians such as Sade Adu, Seal, Tunde Baiyewu (Lighthouse Family), Simon Webbe (Blue), Wale, Taio Cruz, Chamillionaire, Lemar, and Jidenna.

Clearly, Nigeria has a significant diaspora population that has excelled in various fields in their host countries. However, it is important to engage how, if at all, these individuals have enhanced Nigeria's soft power. Artists such as Simon Webbe and Jidenna have promoted Nigerian culture. For example, a track on Simon Webbe's album titled Sanctuary includes some Yoruba (one of the dominant Nigerian languages) lyrics. Jidenna often wears traditional Nigerian attire such as his red caps and Ankara prints and he included Nigerian pidgin English in his hit song, Little Bit More, thereby debunking negative stereotypes such as drug dealers and human traffickers that are often attached to Nigerians.

Through Afrobeats, Nigeria has "created the first pan-African music" (France 24, 2017: para. 7). Thanks to the DStv platform, Afrobeats is aired on dedicated music channels such as MTV, Channel O, Soundcity TV, and Trace Africa. The songs are also available online for those who have access to reliable Internet and data. With about 200 million inhabitants, Nigeria is the most significant market on the continent. Thus, other African states' artists often scramble for collaboration with Nigerian artists in order to access this strong market (France 24, 2017). Weighing in on the influence of Afrobeats, Jidenna noted that 'it doesn't just move your upper body, it moves your hips as well, and I think that's what people have been missing in popular music for a while. I think that's what people need around the world" (Coaston and O'Donnell, 2016: para. 6). The President of Columbia Records UK, a conglomerate of Sony Music, Ferdy Unger-Hamilton, observed that:

I only began to realise that Afrobeats was going to be big when we were all fighting over the D'banj single, which eventually went to Kanye's label in the summer of $2012 \ldots$ And I was silly enough to think this was going to be a one-off. [...] Until I noticed a few weeks later that D'banj feat Davido had just sold out the Hammersmith Apollo. The music has now been adopted into the wider culture.

(Norbrook, 2020: para. 13)

Nigeria has also been able to fill the vacuum created by the cessation of continent-wide entertainment events. For example, following the halt in the 
production of Big Brother Africa after the 2014 show, Nigeria provided Africans with the Pan-African entertainment they so much enjoy with its Big Brother Naija. Similarly, after MTV Africa ceased its annual awards to African music artists, Nigeria filled the void with its Soundcity MVP awards. Nigeria thus continues to demonstrate that indeed "Africa's entertainment wears a made in Nigeria label" (Tella, 2017: 111).

\section{Other cultural soft pozer currencies}

Nigeria can also lay claim to the cultural soft power transmitted by its multinational corporations. Companies like the Dangote Group, Globacom Group, First Bank, and Zenith are important in this regard. The Dangote Group is the largest cement producer in Africa and has its tentacles in ten African states. Its founder and chairperson is the richest person in Africa and the 162nd richest person in the world (Forbes, 2020). His influence radiates beyond Africa as he was ranked the 41st most influential individual in the world in the Bloomberg 50 Most Influential, which included individuals such as Xi Jinping, Barack Obama, and Angela Merkel (Bloomberg, 2015). The 2015 Brand Africa survey described Dangote as the "Brand Builder of the Year" (Brand Africa, 2015). In the 2020 Brand Africa survey, Nigerian alongside South African companies dominated the list of the 25 most admirable African brands (Brand Africa, 2020), with Dangote ranked the most admirable brand on the continent. Other Nigerian companies on the list include Globacom, Innoson, Nasco, Jumia, and the United Bank for Africa (UBA) (Brand Africa, 2020). This implies that many people in Africa construct their buildings using Nigerian cement, communicate by means of Nigerian telecommunication service providers, consume Nigerian made groceries, drive cars made in Nigeria, and transact with Nigerian banks. This is the ultimate display of economic and cultural diplomacy which redounds to soft power.

The Nigerian fashion industry is also booming and has popularised Nigerian fashion designers such as Deola Sagoe, Folake Folarin-Coker, Duro Olowu, Ade Bakare, and Lisa Folawiyo; and Ankara print across Africa and beyond. Former US first lady Michelle Obama and top celebrities across the United States and Europe wear prints made by Nigerian designers (Offiah, 2017). This reflects the increasing influence of Africa's fashion industries in the world, which has led to the popularity of African fashion designers including Nigerian Lisa Folawiyo, South African David Tlale, and Ghanaian Oswald Boateng on the continent and in Europe and the United States, with Western designers like Paul Smith and Louis Vuitton drawing inspiration from African concepts (Tella, 2018a). In acknowledgement of this industry's potential, the Nigerian government formulated the Cotton Textile and Garment policy in 2014 and injected 100 billion naira into the Textile and Garment Intervention Fund. While implementation leaves much to be desired (Offiah, 2017), the growing global popularity of African prints offers Nigeria a soft power tool to promote economic and cultural diplomacy in the global arena. 


\section{Nigeria}

Other sources of Nigeria's cultural attraction include the influence of its literary icons, such as Wole Soyinka (a Nobel Laureate winner), Chinua Achebe, and Chimamanda Adichie, who have followers across the globe and whose works have influenced other literary figures and ordinary people around the world. The tragic collapse of Temitope Joshua's Synagogue church building that resulted in the death of 115 people, more than half of whom were South Africans, revealed some of the intricacies of Nigerian mega churches. However, it also highlighted the fact that Nigeria has emerged as an important destination for religious tourism, which has been eased by the presence of Nigerian mega churches such as the Redeemed Christian Church of God (RCGG) and the Winners Chapel International across Africa and beyond, elevating the status of popular Nigerian pastors such as Enoch Adeboye, David Oyedepo, Chris Oyakhilome, and Temitope Joshua (Ogunnubi and Isike, 2015). The popularity and ministrations of these pastors, who have huge followings across the continent, have the potential to win hearts and minds of citizens across Africa.

Nigeria also boasts of a significant diaspora that makes a positive contribution in many specialised fields such as medicine, academia, architecture, engineering, and entertainment in North America, Europe, Asia, and the Caribbean. To name but a few, the list includes: Aljazeera's Femi Oke, CNN's Zain Asher, and Euronews's Tokunbo Salako in the media; Anthony Joshua - holder of the International Boxing Federation (IBF), International Boxing Organisation (IBO), World Boxing Association (WBA) and World Boxing Organisation (WBO) heavyweight titles, and Israel Adesanya - holder of the Ultimate Fighting Championship (UFG) middleweight title in kickboxing; as well as architect, David Adjaye who designed the elegant National Museum of African American History and Culture in Washington. These personalities are well placed to promote the Nä̈a brand.

\section{Democracy promotion and peace diplomacy}

\section{Democracy promotion}

Another important source of Nigeria's soft power is its democracy promotion in Africa. The state's commitment to this cause is evident irrespective of the nature of its successive regimes, whether authoritarian or democratic. During the military regime of Sani Abacha, Nigeria reinstated President Tejan Kabbah in Sierra Leone following a military coup organised by Major Johnny Paul Koromah (Obi, 2009). The democratic administration of President Olusegun Obasanjo restored São Tomé and Príncipe's President Fradique de Menezes after he was toppled in a military coup while he was attending a summit in Nigeria. Nigeria's former President Olusegun Obasanjo alongside then South African President Thabo Mbeki was instrumental in the formation of key institutions like the African Union (AU) and the New Partnership for Africa's Development (NEPAD) that underscore democratic values and human rights (Burgess, 2020). Abuja's promotion of democracy in Africa is based on a number of principles. These include 
rejection of the unconstitutional overthrow of democratically elected governments, financial and technical aid to states in transition, demonstrating leadership and providing support to institutions that promote democratic values, and promoting peace and conflict resolution on the continent (Omotola, 2008). It is against this backdrop that the Obasanjo administration was vocal in its support of the criminalisation of forceful seizure of power in Africa at the Organisation of African Unity (OAU) summit in Algeria in 1999 (Omotola, 2008).

As I have argued elsewhere, the Sierra Leonean intervention highlights a smart power approach (an effective combination of hard and soft power) in that Nigeria led the Economic Community of West African States Monitoring Group (ECOMOG) force to fight the Johnny Paul Koromah Armed Forces Ruling Council and reinstated the democratically elected President Tejan Kabbah (Tella, 2018b). While the use of the ECOMOG force illustrates the hard power dimension of the incident, the restoration of democracy highlights the soft power context. In terms of São Tomé and Príncipe, Nigeria relied almost entirely on soft power as the Obasanjo administration, in consultation with the AU (while considering the possibility of military intervention) led the conflict resolution efforts that culminated in a memorandum of understanding and the restoration of democracy (Tella, 2018b). More specifically, Obasanjo organised a meeting between the leader of the coup Major Fernando Pereira and a Nigerian envoy. This led to the signing of a memorandum of understanding between all the stakeholders, paving the way for the return of President Fradique de Menezes to power. This achievement prompted Obasanjo to assert that, "you may now, no doubt, agree that the return of President Menezes to power, and the restoration of democracy in the Democratic Republic of São Tomé and Príncipe, was a remarkable achievement for Nigeria's foreign policy" (Omotola, 2008: 40). Although the Junta might have feared the possibility of Nigeria's military intervention in light of Obasanjo's rhetoric and strong condemnation of the coup, the bottom line is that Nigeria's concrete action in resolving the crisis through consultation with the AU and providing leadership in the signing of a memorandum of understanding demonstrate a soft power stratagem.

Nigeria played a significant role in the restoration of democracy in Cote d'Ivoire after a military coup organised by General Robert Guei resulted in the ousting of President Henri Konan Bédié in 1999. Abuja responded swiftly, condemning the coup and calling on Guei to ensure a transition to democracy in six months. Nigeria then provided leadership in an Economic Community of West African States (ECOWAS) mediation process that culminated in the presidential election in 2000 (Omotola, 2008) and Laurent Gbagbo's presidency. In the Gambia, Nigeria was actively involved in ECOWAS's efforts to restore democracy following incumbent President Yahya Jammeh's refusal to step down after he was defeated in a presidential election by opposition candidate Adama Barrow in 2016. Nigeria and Senegal provided leadership as ECOWAS condemned Jammeh's decision to reject the electoral results and remain in office, a move that member states considered not only threatened peace and stability in the Gambia but the entire sub-region (Hartmann, 2017). Jammeh's action prompted 


\section{Nigeria}

President-elect Barrow to flee to Senegal in the face of looming threats to his security. The ECOWAS mediation team comprised then ECOWAS Chairperson, then Liberian President Ellen Johnson-Sirleaf, then Nigerian President Muhammadu Buhari, then Ghana's President John Dram ani Mahama, and then Sierra Leone's President Ernest Bai Koroma. However, Jammeh was unyielding (Hartmann, 2017), resulting in the continuation of negotiations led by Nigeria and Ghana and the threat of force led by Senegal with the assistance of the Nigerian navy (Tella, 2018b). Jammeh eventually stepped down as it became increasingly clear that ECOWAS was prepared to consider all available options to restore democracy in the Gambia. Nigeria's leadership was more evident in the soft power dimension (the negotiations) as opposed to Senegal's focus on the hard power context of the conflict resolution efforts.

Abuja has promoted democracy in other states such as in Togo and Liberia in 2005 as well as in Guinea Bissau and Mali in 2012. In Togo, after the attempted military coup as a result of the death of long-time dictator Gnassingbé Eyadéma, ECOWAS's intervention (led by Nigeria) culminated in the military's decision to allow democratic elections which resulted in Faure Eyadéma - the son of the deceased president - becoming president. President Obasanjo's Special Assistant on Public Affairs Femi Fani-Kayode noted: "whatever it takes to ensure there is peace, democracy and stability in the West African sub-region, we will do" (Omotola, 2008: 40). The Malian case was somewhat complicated. In 2012, following the Tuareg rebels' capture of Northern Mali and the declaration of the Republic of Azawad, Captain Amadou Sanogo led a military coup in Bamako which resulted in the AU's suspension of Mali (Burgess, 2020). By June, different extremist groups had taken control of the northern part of Mali and threatened to take over the entire country. Nigeria negotiated with Sanogo to ensure a military transition to civilian rule and allow an ECOWAS force that would guarantee such transition (Burgess, 2020). However, in the face of Nigerian troops' apparent inability to prevent the rebels from advancing towards the Malian capital, France intervened and defeated the rebels.

It is clear from the foregoing that Nigeria has often preferred the use of a multilateral platform in pursuit of its foreign policy objectives. While its economic and military capabilities have positioned Abuja to be able to achieve its objectives through coercion, it has often eschewed this approach. As Nye (2004) argues, multilateralism as opposed to unilateralism is a soft power booster. Thus, Nigeria has arguably enhanced its soft power appeal through its multilateral posture seen in its use of international organisations, especially ECOWAS in pursuit of its foreign policy objective of democracy promotion.

\section{Peacemaking and peacekeeping}

Nigeria's image as a major peacemaker and peacekeeper on the continent is a fundamental soft power booster. Its peace missions in Liberia, Sierra Leone, the DRC, Mali, and Sudan are notable. Abuja's peacemaking and peacekeeping in Africa stems from the realisation that this is necessary to guarantee its domestic 
security. In doing so, it has eschewed the conflict associated with colonial boundaries by signing bilateral agreements with states such as Equatorial Guinea in 1988 (Kuna, 2005). Nigeria's peacemaking role is further demonstrated by its mediation efforts in the conflicts between Burkina Faso and Mali in the mid1980s (Kuna, 2005). Perhaps the most significant example of Abuja's peaceful resolution of disputes in lieu of conflict is the crisis between Nigeria and Cameroon over the Bakassi Peninsula. While Nigeria clearly had more military capability than Cameroon and could have decided to ignore the ruling of the International Court of Justice (ICJ) that ceded the oil rich Bakassi Peninsula to Yaoundé, Abuja embraced peace and avoided a war over the territory.

Nigeria's peacekeeping operations can be traced back to 1960 in the Congo. This was followed by: interventions in West New Guinea, Tanzania, and IndiaPakistan in the 1960s; Lebanon in the 1970s (Hamman and Omojuwa, 2013); Angola, Chad, Iran-Iraq, Iraq-Kuwait, Lebanon, and Namibia in the 1990s; states such as Bosnia-Herzegovina, Cambodia, Chad, Croatia, Liberia, Mozambique, Rwanda, Sierra Leone, Somalia, and Western Sahara in the 1990s (Sanda, 2012) and in Sudan, Sierra Leone, Liberia, and the Gambia since the year 2000. It is no wonder that Nigeria had contributed more than 200,000 troops to peacekeeping missions by 2010 (Tella, 2018b). In Liberia, by 1990, there was fear that the state would become ungovernable. While the UN was reluctant to intervene, Nigeria provided leadership for ECOWAS to resolve the crisis by sending 3,000 troops that resulted in negotiations between the warring factions and the 1997 elections (Kuna, 2005). During the civil war in Liberia in the 2000s that came to its climax in 2003 when the rebels were apparently close to capturing the capital Monrovia and ousting President Charles Taylor, the Obasanjo administration led the negotiations that ended the civil war. Abuja provided leadership in the ECOWAS mission that removed Taylor and ensured a transitional government, the democratic election of President Ellen JohnsonSirleaf, and security-sector reform (Burgess, 2020). In Sierra Leone, a Nigerianled ECOWAS force conducted peacekeeping and peace enforcement operations to restore President Ahmed Kabbah in 1998 after he was ousted in a military coup in 1997 and played a critical role in the peace agreement that was signed in Lome, Togo in 1999 (Hamman and Omojuwa, 2013).

In the missions in Liberia and Sierra Leone, Nigeria provided around 80 per cent of the troops and 90 per cent of the funding, and suffered 1,000 casualties (Obi, 2009). The state's success in Liberia impressed the Clinton administration to the extent that the United States decided to support Nigeria's peace missions in lieu of intervening directly in conflict zones (Bach, 2007). Nigeria's intervention in the Darfur genocide in 2003/2004 was born out of the moral imperative to halt human rights abuses and ensure peace (Burgess, 2020). President Obasanjo, who was the AU Chair at the time, played a critical role in negotiating with the Sudanese government, the Sudan People's Liberation Movement (SPLM), and the Justice and Equality Movement (JME) to end the conflict that started in 2003 (Ebegbulem, 2011). Alongside Chad's President Idriss Déby, his intervention resulted in Intra-Sudanese Dialogue in September 2003, which 


\section{Nigeria}

culminated in peace talks in Abuja in 2004 (Burgess, 2020). However, Nigeria's intervention did not halt the genocide, prompting Abuja to seek the help of the UN Security Council in the form of the UN's African Union Mission in Darfur (UNAMID), with Nigeria contributing the most troops (Burgess, 2020). This demonstrates that Nigeria has exercised soft power in its peacemaking and peacekeeping operations in key conflict theatres across Africa and beyond. The benefits include its global status as one of the most important peacemakers in Africa and being elected five times as a non-permanent member of the UN Security Council.

However, Nigeria's credential as a major contributor of troops to UN peacekeeping efforts has continued to decline in the past few years from fifth position to forty-third. This might impact its quest to become a permanent member of a reformed UN Security Council as the West African Gulliver relied on this contribution as an important credential in its quest. Nonetheless, Nigeria continues to contribute to key strategic peacekeeping missions. Table 3.4 shows the country's contribution by June 2020 .

While the soft power embedded in peacemaking is clear as it embodies diplomatic action towards a negotiated agreement, peacekeeping does not fit neatly into a soft power stratagem as it entails the deployment of troops. However, the success of Nigerian troops in places like Liberia and Sierra Leone generated admiration in Africa and beyond, which redounded into soft power seen first in

Table 3.4 Nigeria's contribution to UN peacekeeping operations

\begin{tabular}{lllll}
\hline Mission & Staff officer & $\begin{array}{l}\text { Experts on } \\
\text { mission }\end{array}$ & Police & Contingent troops \\
\hline $\begin{array}{l}\text { MINUSMA } \\
\text { (Mali) }\end{array}$ & 15 & 4 & 142 & 63 \\
$\begin{array}{l}\text { UNMISS (South } \\
\text { Sudan) }\end{array}$ & 5 & 5 & 16 & \\
$\begin{array}{l}\text { UNAMID } \\
\text { (Darfur) }\end{array}$ & 6 & 12 & 4 & \\
$\begin{array}{l}\text { MONUSCO } \\
\text { (DRG) }\end{array}$ & 8 & 4 & & \\
$\begin{array}{l}\text { MINURSO } \\
\text { (Western }\end{array}$ & & 3 & & \\
$\begin{array}{l}\text { Sahara) } \\
\text { MINUSCA }\end{array}$ & 3 & 1 & & \\
(CAR) & & 1 & & \\
UNISFA (Abyei) & 2 & & & \\
UNIFIL & 1 & & & \\
(Lebanon) & & & & \\
$\begin{array}{l}\text { UNMHA } \\
\text { Yemen) }\end{array}$ & & & & \\
\hline
\end{tabular}

Source: author's adaptation from United Nations data base, https://peacekeeping.un.org/en/troop -and-police-contributors. 
its impact on Nigeria's image in the UN as one of the major keepers in the world - an important credential in its quest to become one of the permanent African members of the UN, if the international organisation is reformed. The second manifestation was the then Clinton administration's decision to assist Nigeria's peacekeeping efforts in Africa rather than intervening directly. It is also noteworthy that the troops have participated in all spheres of the peace process, including humanitarian assistance and peacebuilding.

\section{Omolúwàbí and the Technical Aid Corps Scheme}

\section{Omolúwàbi}

The Yoruba philosophy Omolúwàbi holds that all citizens should strive for a virtuous character. "The Yoruba, predominantly of southwest Nigeria, comes with a long history of deep cultural consciousness and identity defined by the Omolúwàbi essence - a sense of, commitment to, and pride in pristine and honorable conduct, individually and corporately" (Mimiko, 2017: 243). In simple terms, it refers to personhood or an epitome of good character. The attributes of Omolúwàbi include self-discipline, self-reliance, trust, tolerance, humility, selfless service to humanity, self-respect, courage, equity, diligence, and honesty in public and private dealings. A person who does not exhibit these qualities is often regarded as omolasan (someone with a questionable character). The character of an Omolúwàbi often reflects the family and society to which they belong. Thus, an Omolúwàbi exhibits the good character of an individual as well as their family and the community (Olanipekun, 2017). Indeed, omolasan is seen as a misfit in the community who cannot be socially integrated.

As a regional power, Nigeria is well placed to develop and promote the philosophy of Omolúwàbi in Africa and further afield. Among other things, this could help to combat corruption and promote good governance as well as serve as a veritable tool for conflict resolution in Africa and beyond. In terms of conflict resolution, settling disputes in Africa by appealing to the Omolúwàbi (conscience) of the parties in conflict, with African elders playing an important role as exemplified by the AU's Panel of the Wise, could assist in resolving some African conflicts. In terms of corruption, this is a global menace that cuts across states irrespective of whether they are democratic or authoritarian, developed or developing, and Western or non-Western. The philosophy of Omolúwàbi has universal relevance in this regard as it emphasises self-discipline, self-control, integrity, and a sense of responsibility (Dauda, 2017). In emphasising morality, it also offers an alternative paradigm to the realist's narrow interpretation of international relations that downplays morality and emphasises realpolitik and states' narrow interests. As Dauda argues, the philosophy can be developed:

as a hybrid corpus of unwritten constitutions to redeem the years of slavery, colonization, and the consequent bastardization of African self-image and identity. Thus, beyond the ideological revisionism of the protagonists of 


\section{Nigeria}

negritude and also of the various forms of African socialism, ... omolúwàbi, if developed, ... represents enduring indigenous systems of African humanism and ethical governance, that is, somehow democratic, equitable, morally responsive, and selfregulating.

(Dauda, 2017: 476-477; emphasis in original)

In developing this philosophy, Nigeria could learn from South Africa whose foreign policy (at least at the level of rhetoric) is guided by the philosophy of Ubuntu. Beyond the principles of basic protection of the individual's rights and property that underline Western democracy, Omolúwàbi underscores equal opportunity in access to political, economic, and social resources (Dauda, 2017). An Omolúwàbi is an epitome of good character that is worthy of emulation. If most (if not all) individuals in a society can imbibe these principles, society and by extension, the world would be a better place. If Nigeria were to promote this ethos at the national level, Abuja would have the moral authority to promote it in Africa and beyond. Encouraging Nigerian citizens to abide by the principles of Omolúwàbi and incorporating same in Nigeria's citizen diplomacy and its broader foreign policy seems imperative in an age of anti-Nigerian sentiment. Success in this regard would no doubt add an important dimension to Nigeria's soft power currencies.

\section{Technical Aid Corps}

The Nigerian Technical Aid Corps (TAC) is a voluntary international service scheme established in 1987 to serve as an institutional framework to provide aid to African, Caribbean, and Pacific (ACP) states. Its major objective is to provide Nigerian technical know-how in fields such as architecture, engineering, law, medicine, science, and sports to states in these regions that lack adequate personpower. According to the Directorate of Technical Aid Corps' (DTAC) website, the TAC aims to:

1 Share Nigeria's know-how and expertise with other ACP countries;

2 Offer assistance on the basis of the assessed and perceived needs of the recipient countries;

3 Promote cooperation and understanding between Nigeria and the beneficiary countries; and

4 Facilitate meaningful contact between the youth of Nigeria and those of the recipient countries.

The soft power of this novel scheme stems from the fact that it is grounded in the principle of shared South-South ownership, evident in the intersection of Nigeria and the recipient states' national interests, and is free from economic and political conditionality (Jinadu, 2016). While Nigeria's ownership is evident in the fact that it is the initiator and that it controls the selection of volunteers, recipient states can lay claim to ownership because they determine areas of need and the 
required number of volunteers (Jinadu, 2016). Volunteers are only sent on request from beneficiary states, which gives a sense of ownership to both parties. The volunteers' salaries are paid by the Nigerian government, freeing recipient states from any financial costs. This is an important soft power tool that has the potential to challenge the negative stereotypes associated with Nigeria, including corruption, fraud, and drug dealing. As Bolaji Akinyemi, Nigeria's former Minister of Foreign Affairs who designed the scheme noted:

So, that when people talk about 419 (Advance Fee Fraud) and the "ugly Nigerian" in a particular country, they will remember that there was that engineer who helped to build our express road, he was a Nigerian; or the nurse who helped save my baby when my baby was sick, was a Nigerian; or the medical doctor that was attached to the State House was a Nigerian.

(Adebanwi, 2011: 23)

Ongoing requests for volunteers from ACP states demonstrate that Nigerian skilled workers are admired. The TAC has cemented Nigeria's role as a major aid donor in these regions, reinforcing its soft power. Since 1987, the scheme has deployed more than 4,000 volunteers to 38 recipient ACP states (Jinadu, 2016).

Former Ethiopian Prime Minister Meles Zenawi noted that the TAC had a significant impact on the socio-economic development of ACP states (Directorate of Technical Aid Corps, 2020), while a top Ethiopian official stated that "even though their country was receiving similar manpower training aid from Japan and Britain, their observation in the two years of the TAC scheme in Ethiopia has shown that Nigerian volunteers were the most dedicated" (Adebanwi, 2011: 34). Similarly, former Namibian President Sam Nujoma observed that "Nigeria has continued to grant development assistance and personnel to support my government's socio-economic programmes, including the Technical Aid Corps Agreement under which Nigerian experts work in Namibia" (34). These statements highlight that Nigerian volunteers are appreciated, resulting in positive perceptions of the Nigerian work ethic. As I have argued elsewhere, while Nollywood is Nigeria's most significant cultural soft power, "the TAC appears to be one of the most significant foreign policy instruments that enhances such power" (Tella, 2017: 110). Nye notes that rather than economic and military capacity, some states' influence is largely derived from their attractive features like economic aid and peacemaking. Nigeria's peacemaking and peacekeeping in places like Liberia, Sierra Leone, Chad, and Mali; and its aid channelled through the TAC in states such as Benin Republic, Burkina Faso, Cape Verde, Ethiopia, Angola, Kenya, Dominica, Guyana, and Jamaica, are thus important in promoting its soft power and influence in Africa and further afield. "Its (Nigeria's) contribution to the development of Africa rekindles its role of big brother on the continent. It also reinforces NEPAD's vision of African ownership of development initiatives and African solutions to African problems" (Tella, 2017: 114).

The scheme has received commendations from diverse international organisations such as the Commonwealth, the UN Volunteer Service, ECOWAS 
Volunteers Programme, and the Japanese Agency for International Cooperation (Tella, 2017). The AU, the Commonwealth, the UN Volunteer Service, the Canadian International Development Agency (CIDA), and the Japanese Agency for International Cooperation have reached out to the Nigerian government for advice on how to design and operate their own technical assistance programmes (Jinadu, 2016). This implies that the TAC serves as a model for similar schemes and is the ultimate exercise of soft power.

In terms of the concrete impact of the scheme: volunteers in Fiji assisted in the drafting of the country's new constitution; two volunteers in the Gambia were retained after their service and went on to become the Vice-Chancellor and Registrar of the University of the Gambia; in Kenya, two volunteers were retained and became directors at Shelter Afrique; and the AU deployed TAC volunteers to serve in post-conflict reconstruction initiatives in Sierra Leone (Jinadu, 2016). It is against this backdrop that non-ACP states such as Vietnam and North Korea have indicated their interest in hosting TAC volunteers. All these examples show that the services offered by TAC volunteers are admired, appreciated, and recognised. It is thus an important platform to challenge negative stereotypes of Nigerians. However, Ogbonna and Ogunnubi (2018) argue that while other states have taken advantage of soft power volunteer schemes like the TAC to influence the foreign policy of recipient states, Nigeria has lagged behind. They thus submit that the TAC's potential as a soft power scheme is debatable. In view of the concrete impacts highlighted above, I would argue that this is not a fair assessment as the scheme is arguably one of Nigeria's most important foreign policy instruments that promotes Abuja's soft power.

Beyond the aid channelled through the TAC, Abuja has provided economic and financial assistance to other African states, acting as what is akin to a benevolent hegemon. For example, it offered its close neighbour, Benin, an interestfree loan of around $\$ 1.2$ million in 1972 to be repaid over 25 years, and paid the outstanding salaries of Benin's civil servants to the tune of $\$ 2.5$ million (Osuntokun, 2008). In 1976, Nigeria established the Southern African Relief Fund to provide education and welfare services to victims of apartheid. The amount Nigeria spent on its fight against apartheid is subject to debate, with estimates ranging from $\$ 1$ billion to tens of billion dollars (Tella, 2018b). In the course of fighting this oppressive regime, Nigeria donated $\$ 10$ million to Botswana, Zambia, and Zimbabwe to provide safe havens for members of the African National Congress (ANG) (Saliu and Omotola, 2008). In Angola, Nigeria supported the Popular Movement for the Liberation of Angola (MPLA) and offered $\$ 20$ million as aid with a further promise of $\$ 100$ million to support the organisation's struggle for the Southern African state's independence. In reaction to apartheid South Africa's support for a rival group, the Union for the Total Independence of Angola, Nigeria provided arms to the MPLA (Fawole, 2003). Nigeria's unwavering support resulted in Angola's independence and the emergence of the MPLA government. In recent times, Nigeria donated $\$ 500,000$ towards Guinea Bissau's elections (Oshewolo, 2019b) and deployed 250 health personnel to Guinea, Sierra Leone, and Liberia during the 2015 Ebola crisis. 
These volunteers worked closely with the AU, the African Development Bank (ADB), and the World Health Organisation (WHO) (Umezurike et al., 2017).

\section{Multilateralism and membership of international organisations}

Nigeria was the pioneer of ECOWAS, arguably the most successful sub-regional organisation in Africa. The state also played a leading role in the establishment of the OAU and its transition to the AU. The OAU was established in 1963, three years after Nigeria's independence. Thanks to the efforts of the Balewa administration, its charter reflected the principles of Nigeria's foreign policy (Ogunbadejo, 1980). Alongside South Africa, Nigeria was instrumental in the transition of the OAU to the AU in 2002 and the establishment of NEPAD and the African Peer Review Mechanism (APRM). Nigeria has been elected as a non-permanent member of the UN Security Council five times: 1966-1967, 1978-1979, 1994-1995, 2010-2011, and 2014-2015, highlighting the regional power's meaningful contribution to the organisation.

\section{ECOWAS: Nigeria's sub-regional integration efforts}

Nigeria's commitment and approach to ECOWAS in the formative years were informed by the challenges confronting the West African sub-region such as the prevalence of military rule (including Nigeria), political instability, a development deficit, and the rivalry between Anglophone and Francophone states (Akinola, 2019). The political instability that arose from pervasive unconstitutional changes in government across the sub-region resulted in political and security issues rather than economic integration being the raison d'être for the establishment of the organisation. These issues also dominated ECOWAS's activities, particularly between the 1980s and 1990s (Akinola, 2019). The formal defence treaty that Nigeria and Togo proposed immediately after the establishment of ECOWAS resulted in a non-aggression pact that was ratified in 1986, and in 1991 member states ratified a declaration of political principles, committing them to uphold democracy and the rule of law (Osondu, 2015). Similarly, in 1999, Nigeria provided leadership in negotiating the ECOWAS Mechanism for Conflict Prevention, Management, Resolution, Peacekeeping and Security which was instrumental in the establishment of security architecture as well as the 2001 Supplementary Protocol on Democracy and Good Governance (Burgess, 2020). This pact and declaration, together with the two defence protocols that were signed in 1978 and 1981 (Osondu, 2015), provide the normative frameworks and soft power basis for Nigeria to intervene in conflict zones and promote democracy in the sub-region. Nigeria led ECOWAS member states' efforts to establish ECOMOG, a peacekeeping/peace enforcement force that was instrumental in Nigeria's successful intervention in conflict zones like Liberia and Sierra Leone.

The exponential increase in the price of oil following the Arab-Israeli conflict in 1973 and Nigeria's emergence as a major supplier of oil to the West, gave Abuja the financial clout to pursue its foreign policy objectives in ECOWAS as its 


\section{Nigeria}

economic rejuvenation enhanced its status among other West African states (Ojo, 1980). Nigeria accounts for almost 70 per cent of the sub-region's economy, enhancing Abuja's capacity to provide leadership and sway the direction of ECOWAS member states. As noted earlier, Nigeria used ECOWAS as a platform to promote democracy and prevent unconstitutional changes in government across West Africa in places such as Guinea Bissau, Mali, Togo, and Liberia. In Mali alone, Abuja committed 7 billion Naira and around 1,200 troops and offered to construct clinics for the Malian military (Omo-Ogbebor, 2017). Nigeria also used ECOWAS to ensure peaceful resolution of conflict in states such as Liberia, Sierra Leone, and Togo. The state's diplomatic soft power was also critical in resolving the Mano River conflict between Liberia, Sierra Leone, and Guinea (Omo-Ogbebor, 2017). This is another important example of the successful exercise of soft power. Nigeria's Obasanjo and Ghana's Acheampong noted that:

"Our goal ... is collective self-reliance," to change "the North-South trade pattern dominated by the industrialized countries," and to enhance the capacity to redress the "yawning gap between the rich and the poor countries" - a gap which "even the United Nations and similar bodies dominated by the industrialized nations" have, most regrettably, been unsuccessful in bridging. The "main instrument for achieving this goal in this subregion is ECOWAS".

(Ojo, 1980: 599)

In other words, while division between Anglophone and Francophone states was rife, ECOWAS bridged this gap by enhancing the sub-region's integration through strengthening its capacity for conflict management and boosting the profile of West Africa in the global arena (Kuna, 2005). The 1979 Protocol Relating to the Free Movement of Persons, Residence, and Establishment is one of the most remarkable in the world, accounting for cross-border mobility rates of around 68 per cent in the sub-region (Tella, 2019a). The ECOWAS external tariff and a customs union became operational in 2015 (Hulse, 2016). ECOWAS has thus served as an important platform for Nigeria to deploy its soft power currencies to promote its foreign policy objectives of democracy promotion and peacemaking.

\section{The African Union: Nigeria's regional integration efforts}

The establishment of the OAU in 1963 provided an avenue for Nigeria to exercise its soft power and regional powerhood. However, the rise to power of successive military administrations and their uncoordinated foreign policy behaviour resulted in the decline of Abuja's influence in Africa and globally (Oshewolo, 2019b). The exception was the Murtala/Obasanjo administration between 1975 and 1979. The return to civilian rule in 1999 under Obasanjo's administration rekindled Nigeria's regional and global image and influence. 
Nigeria provided leadership in the establishment of the OAU. The conference in which the structure and workings of the organisation were engaged was held in Nigeria in 1962, its charter significantly reflected the principles of Nigeria's foreign policy, and Nigeria contributed fundamentally to the structure and priorities of the OAU (Ogunbadejo, 1980; Oshewolo, 2019a). The divergent views of the so-called Monrovia group led by Nigeria, and the Casablanca group led by Ghana and Guinea, almost derailed the formation of the OAU. However, Nigeria used its diplomatic influence to ensure that the Pan-African organisation became a reality. This prompted Obasanjo to note that, "but for Nigeria's mature and modest diplomacy in reconciling the Monrovia and the Casablanca ideologically-separated groups, the formation of the organisation in 1963 would not have been a reality" (Oshewolo, 2019a: 4). Nigeria successfully used the OAU to promote its foreign policy objective of eradicating colonialism and white minority rule across Africa in places like Angola, Guinea Bissau, Mozambique, Namibia, Zimbabwe, and South Africa. Abuja also contributed to the normative ideas that guided the principles of the AU. While unilateralism often undercuts a state's soft power, multilateralism under the platform of a regional organisation like the AU has enhanced Nigeria's Pan-Africanist credentials and soft power.

The Obasanjo administration's contribution (rhetoric and practical action) to the OAU's transition to the AU cannot be overemphasised. Obasanjo's reformist ideas were spelt out in the Memorandum of Understanding of the Conference on Security, Stability, Development and Co-operation in Africa (CSSDCA), which was later adopted in the AU's Summit in South Africa in 2002. The CSSDCA emphasises four key parameters - security, stability, development, and cooperation - as essential for good governance in Africa (Tieku, 2004). Nigeria has thus promoted itself as a norm entrepreneur in Africa. In 2000, during the AU Summit in Togo, Obasanjo noted that Africa's perpetual challenges are not due to a lack of ideas or policy initiatives but rather due to capacity issues (Oshewolo, 2019a). The formation of the AU was deemed critical to solve the capacity deficit. Thanks to Obasanjo, along with the efforts of key African leaders - South Africa's Thabo Mbeki, Libya's Muammar Ghaddafi, Senegal's Abdoulaye Wade, and Algeria's Abdelaziz Bouteflika - the AU was established in South Africa in 2002.

The Nigerian Embassy in Ethiopia and the country's Ministry of Foreign Affairs played a pivotal role in drafting the instruments that established the AU (Oshewolo, 2019a). Similarly, Nigeria was the brain behind the protocol that established the AU Peace and Security Council (PSG), which became operational in 2004. Abuja tapped its reservoir of knowledge gained through its involvement in peace processes across West Africa through the platform of ECOMOG (Umezurike et al., 2019). Thus, beyond its peacemaking and democracy promotion credentials, Nigeria's soft power in the AU has manifested in its role as a norm entrepreneur. It is against this backdrop that Obasanjo emerged as the first chairperson of the PSC. The Council provides the legal framework for the AU's embrace of the notion of non-indifference as opposed to the OAU's noninterference in the internal affairs of member states. This underscores the 
responsibility to protect African states with or without their consent on humanitarian grounds. During Obasanjo's chairpersonship of the AU (2004-2006), the organisation intervened in conflict zones such as Burundi, Darfur, Comoros, Côte d'Ivoire, Liberia, and Somalia (Oshewolo, 2019a). In a nutshell, the AU's key institutional and normative frameworks to promote democracy and conflict management are the 2002 African Peace and Security Architecture (APSA) and the 2011 African Governance Architecture (AGA). These provided the basis for the AU's peace operations in the aforementioned states and democracy promotion in Togo in 2005, Mali in 2012, and Egypt in 2013 (Tella, 2019a). In addition, Nigeria and South Africa worked closely together to establish the socioeconomic development and governance agencies of the AU, NEPAD, and the APRM, respectively.

\section{The United Nations: Nigeria's efforts in global governance}

Nigeria prides itself on abiding by the purpose and principles upon which the United Nations (UN) was founded and has participated in many UN peacekeeping efforts in Africa in places such as Liberia, Sierra Leone, Cote d'Ivoire, Rwanda, Burundi, and Darfur; and further afield in states such as Lebanon and Croatia (Bamidele, 2015). Unlike a number of states that send troops to UN peacekeeping missions partly for financial gain, Abuja has carried the financial burden of most of its troops in peace operations. These troops have participated in all dimensions of the peace process including humanitarian assistance, peacemaking, peacekeeping, and peacebuilding. Peacekeeping missions that Nigeria has contributed troops to include: the UN Mission in Sierra Leone (UNMSIL) during 1991-2000; the Congo (ONUG) 1960-1964; New Guinea (UNSF) 1962-1963; India-Pakistan (UNIPOM) 1965-1966; Lebanon (UNIFIL) 1978-1983; Iran-Iraq (UNIIMOG) 1988-1991; Iraq-Kuwait (UNIKOM) 1991; Angola (UNAVEM II) 1991-1992; Sierra Leone (NATAG) 1991; Angola (UNAVEM III) 1992-1995; Namibia (UNTAG) 1989-1990; Western Sahara (MINURSO) 1991; Cambodia (UNTAC) 1992-1993; Somalia (UNOSOM) 1992-1994; Yugoslavia (UNPROFOR) 1992; the Gambia (NATAG) 1993; and Israel (UNTSO) 1995 (Bamidele, 2015). Between 1990 and 2014, the UN authorised more than 20 peacekeeping missions across Africa and relied heavily on Nigerian personpower to execute peace operations (Bamidele, 2015). It is thus clear that Nigeria is a global peacemaker, a key soft power booster.

Whilst serving as a non-permanent member of the UN Security Council, Nigeria advocated for national ownership of peacebuilding and urged that states contributing troops should play a more significant role in determining the mandates of peacekeeping missions. This implies that the international community should provide the necessary capacity to states in need during peace operations (Bamidele, 2015). Abuja has also emphasised the need to pay close attention to the non-military aspect of conflicts. In 2011, during his address to the UN General Assembly, then Nigerian President Goodluck Jonathan noted that UN resources and efforts had primarily focused on the military dimension of conflicts as opposed 
to preventive diplomacy (Bakare and Read, 2019). This highlights Nigeria's preference for soft power rather than hard power in its peace operations.

In light of this, coupled with the fact that Nigeria is the most populous country in Africa, and the largest economy on the continent, as well as its remarkable cultural soft power, Abuja seems qualified to fill a permanent seat in a reformed UN Security Council.

Despite claims across many quarters that Nigeria has not benefitted from its Afrocentric foreign policy, Nigeria has filled a non-permanent seat in the UN Security Council five times. The country currently occupies key strategic positions in many international organisations. Ngozi Okonjo-Iweala is DirectorGeneral of the World Trade Organisation (WTO); Akinwumi Adesina is the President of African Development Bank (AfDB); Mohammad Barkindo is Secretary General of the Organisation of Petroleum Exporting Countries (OPEC); and Tijjani Muhammad-Bande is President of the UN General Assembly (UNGA). However, Nigeria's leadership role in these multilateral platforms faces challenges arising from other African states' scepticism regarding the state's true intentions in its international engagement. There are concerns that, like any regional or global power, Nigeria seeks to pursue its national interests at the expense of common African interests, causing these states to play the part of sovereignty hawks and protect their national pride and interests.

\section{Constraints to Nigeria's soft power}

\section{Political corruption and the democracy deficit}

Given President Buhari's tough stance against corruption and indiscipline in his previous military regime (1983-1985), it is not surprising that he launched an anti-corruption campaign in his current civilian administration. However, the initial euphoria that greeted the campaign has dimmed, as is evident in the decline in citizens' positive perceptions of the campaign from 70 per cent in 2016 to 51 per cent in 2019 (United Nations Office on Drugs and Crime, 2019). Corruption poses a significant challenge to Nigeria's ability to fulfil its potential. It is demonstrated by the endemic governance deficit, low Foreign Direct Investment (FDI), and poor infrastructure (PricewaterhouseCoopers, 2016). Despite a series of policies and institutions such as the 1995 Money Laundering Act, the 2000 Independent Corrupt Practices and Other Related Offences Commission (ICPC), the 2004 Economic and Financial Crimes Commission Establishment Act, and the 2004 Money Laundering (Prohibition) Act, and Nigeria's ratification of international conventions such as the 2003 United Nations Convention against Corruption and the 2003 African Union Convention on Preventing and Combating Corruption, the menace remains pervasive. PricewaterhouseCoopers $(\mathrm{PwC})$ estimated that Nigeria could lose 37 per cent of its GDP to corruption by 2030 (PricewaterhouseCoopers, 2016). This is partly due to the fact that the capacity and genuineness of these institutions' fight against corruption - especially politicians - are questionable. 


\section{Nigeria}

While James Ibori, former Governor of Delta State, was arrested by the EFCG in 2008 on charges of corruption, he was acquitted by a High Court in Nigeria, igniting domestic and international condemnation (Muhammad and Salawu, 2020). Ibori was later convicted of graft in London, calling into question Nigeria's anti-corruption campaign. In the case of corruption allegations against Alison Madueke, former Minister of Petroleum, the EFCG only extradited the minister to face corruption charges after she had been arrested in London over money laundering charges and a US Department of Justice lawsuit that sought the reclamation of $\$ 144$ million worth of assets including a $\$ 80$ million yacht and a $\$ 50$ million apartment in New York (Muhammad and Salawu, 2020). The Halliburton scandal is another high profile scandal in which Nigerian public officials were bribed to the tune of around $\$ 200$ million for the award of a $\$ 6$ billion Nigeria Liquefied Natural Gas construction contract. Despite domestic and global outcry, no charges were laid, seemingly because three former Heads of State and other high profile politicians were involved (Tella, 2017). The last straw was corruption allegations against EFCC Chairperson, Ibrahim Magu, that resulted in his suspension in July 2020. It is the ultimate irony when the individual saddled with responsibility to eradicate corruption in the country is seemingly corruptible.

Although the EFCG has prosecuted a few notable public officials such as Bode George, former deputy national Vice Chair of the People's Democratic Party and Tafa Balogun, former Inspector General of Police, corruption remains endemic. Adebanwi and Obadare (2011: 187) capture Nigeria's post-1999 anti-corruption campaign thus:

In the case of Nigeria, the civilian regime's prosecution of an anticorruption campaign has ironically coincided with the reported theft of state resources on a scale that is unprecedented, even by the standards of the country's egregious history of official larceny. Indeed, instead of being eroded, existing networks of patronage and clientelism have consolidated, even expanded, whilst the shady mutuality of state and informal institutions has further encrusted the country's iconography as one of Africa's myriad "shadow states".

Given the ubiquity of corruption in the country, some foreign investors have engaged in corrupt practices to promote their interests. For example, Italy's Eni and Royal Dutch Shell face charges of corruption in a bid to acquire a contested oil block - OPL 245. Some of the key factors responsible for the high levels of corruption include perceptions of political office as a platform to accumulate wealth, weak anti-corruption agencies and initiatives, and a transparency and governance deficit. In its 2019 survey, the United Nations Office on Drugs and Crime found that about 67 per cent of bribes were paid before a public official rendered their services and more than 93 per cent (675 billion Naira) of these bribes were paid in cash (United Nations Office on Drugs and Crime, 2019), removing the possibility of the graft being traced. Table 3.5 shows how Nigeria has fared in the Corruption Perception Index in the past six years. 
Table 3.5 Corruption Perception Index

\begin{tabular}{lllllll}
\hline Year & 2015 & 2016 & 2017 & 2018 & 2019 & 2020 \\
\hline $\begin{array}{l}\text { Score/Scale } \\
\text { Rank/Number }\end{array}$ & $26 / 100$ & $28 / 100$ & $27 / 100$ & $27 / 100$ & $26 / 100$ & $25 / 100$ \\
$\begin{array}{l}\text { of countries } \\
\text { surveyed }\end{array}$ & & $136 / 176$ & $148 / 180$ & $144 / 180$ & $146 / 180$ & $149 / 180$ \\
\hline
\end{tabular}

Source: author's adaptation from Transparency International (2016-2021).

Clearly, Nigeria's ranking in the index leaves much to be desired. This dents its credibility and legitimacy to act as a model for good governance in Africa. It is no wonder that the then UK Prime Minister David Cameron described Nigeria as "fantastically corrupt" in an informal conversation with Queen Elizabeth II at the anti-corruption summit in London (BBC News, 2016). The impact of godfatherism has further entrenched corruption in the country. Key examples include the Chris Uba and Chris Ngige saga and Lamidi Adedibu and number of Oyo state governors, including Rashidi Ladoja and Christopher Alao-Akala. While the Scandinavian states, especially Denmark, Finland, Sweden, and Norway continue to enjoy prestige in the international arena due to good governance and low levels of corruption, Nigeria's global image remains battered, partly due to pervasive corruption.

Although Nigeria is a major promoter of democracy in Africa, its domestic democracy deficit, illustrated by pervasive corruption, violent electoral politics, and poor governance, dictate that Abuja lacks the moral authority to promote democracy in Africa. It is in light of this that I state elsewhere:

$[\mathrm{O}] \mathrm{n}$ what moral grounds can Nigeria as a regional power preach for the eradication of corruption and embrace of good governance in countries such as Zimbabwe, the Democratic Republic of Congo (DRG), Angola and Sudan when it is notorious for corruption in the eyes of the global audience? Its preaching will definitely fall on deaf ears.

(Tella, 2017: 116)

As highlighted earlier, Nigeria's promotion of democracy is remarkable. However, the state does not fare well in promoting "good governance" in its domestic politics. This is compounded by Nigeria's low position in the major indices that measure democratic values and "good governance" including the Freedom House, the Democracy Index, Mo Ibrahim Governance Index, the Transparency Corruption Perception Index, and the Economist Democracy Index. It suggests that the country does not have the moral authority to promote democracy on the continent and deflates Nigeria's soft power gambit. Table 3.6 shows Nigeria's standing in terms of freedom in Africa.

Nigeria does not fare well when it comes to political rights and civil liberties indicators measured by Freedom House - on the continent. With a score of 47, it is ranked as partly free, while the states ranked as free include Botswana, Carbo 
Table 3.6 Freedom in Africa

\begin{tabular}{|c|c|}
\hline Countries & Status \\
\hline $\begin{array}{l}\text { Botswana, Carbo Verde, Ghana, Mauritius, } \\
\text { Namibia, South Africa, São Tomé and } \\
\text { Príncipe, Tunisia }\end{array}$ & Free \\
\hline $\begin{array}{l}\text { Benin, Burkina Faso, Comoros, Côte } \\
\text { d'Ivoire, Guinea, Guinea Bissau, Kenya, } \\
\text { Lesotho, Liberia, Madagascar, Malawi, } \\
\text { Mali, Mauritania, Morocco, Mozambique, } \\
\text { Niger, Nigeria, Senegal, Seychelles, Sierra } \\
\text { Leone, Tanzania, The Gambia, Togo, } \\
\text { Zambia, Zimbabwe }\end{array}$ & Partly free \\
\hline $\begin{array}{l}\text { Algeria, Angola, Burundi, Cameroon, Cen- } \\
\text { tral African Republic, Chad, the Demo- } \\
\text { cratic Republic of Congo, Djibouti, Egypt, } \\
\text { Equatorial Guinea, Eritrea, Eswantini, } \\
\text { Ethiopia, Gabon, Libya, Republic of the } \\
\text { Congo, Rwanda, Somalia, Somaliland, } \\
\text { South Sudan, Sudan, Uganda, Western } \\
\text { Sahara }\end{array}$ & Not free \\
\hline
\end{tabular}

Source: author's adaptation from Freedom House, 2020.

Verde, Ghana, Mauritius, Namibia, South Africa, São Tomé and Príncipe, and Tunisia that recorded 72, 92, 82, 89, 77, 79, 84, and 70 respectively (Freedom House, 2020). The Economist Intelligence Unit's Democracy Index presents a similar result with Nigeria ranking 109th compared with Mauritius, Botswana, Cabo Verde, and South Africa that ranked 18th, 29th, 30th, and 40th, respectively (The Economist Intelligence Unit, 2020). These countries are thus better placed with regard to moral authority to promote democracy in Africa. The soft power benefits associated with Nigeria's foreign policy of democracy promotion are therefore dampened. Agbaje and Adejumobi (2006: 25) analyse the state of affairs in Nigeria thus:

Nigeria has suffered from both institutional (organizations + values / rules/ norms) and experiential deficits in regard of required ramparts for electoral politics conducive to democratic renewal and consolidation. Organisations have been bereft of values required for turning them into effective institutions while dominant values have been toxic to democratic politicking. While years of dictatorship under colonial, military and civil rule partly account for the parlous state of electoral politics in Nigeria, the nature of political leadership, its shortsightedness as well as its lack of commitment to and experience in the democratic management of diversity in the context of restrained governance, have devalued politics and elections in Nigeria, reducing the latter literally to an instrument of warfare by other means. Electoral merchants or better still political barons have hijacked the electoral process marginalizing the people, discountenancing their voices and choices 
and steadily sliding the fourth republic on the path of systemic collapse. Engendering a functional and transparent electoral system will require revaluing institutional capacity and political ethos by the political elites in Nigeria.

Nigeria thus needs to address its "good governance" and democracy deficit if it hopes to acquire the moral authority to preach democracy to other states and maximise the benefits of soft power that accrue from democracy promotion.

\section{Nigeria's image crisis}

A positive image is critical to successful deployment of soft power. Given that soft power is the power of attraction, an actor can only be attracted to another actor if the former sees the latter in a positive light. Therefore, states with enormous soft power enjoy a significant positive image in the hearts and minds of the international audience. One of the major constraints to Nigeria's soft power is its negative image and attendant global anti-Nigerian sentiment. Aside from the country's high levels of corruption noted previously, other major contributors include Nigerian criminal networks that engage in illicit activities such as advance fee fraud (also known as 419 after the relevant section of the Nigerian criminal code), Internet scams (popularly known as Yahoo Yahoo in Nigeria), money laundering, drug trafficking, and human trafficking.

Nigeria's advance fee fraud thrives in Malaysia and Indonesia both in terms of victims and as the operational base for the Nigerian criminal networks whose fraud ranges from credit card scams to financial fraud and love scams (Owoyemi et al., 2015). In what is often described as the biggest advance fee fraud in Nigeria, Emmanuel Nwude, a former Director of Union Bank, and his accomplice convinced Nelson Sakaguch, a Brazilian banker at Banco Nordeste in São Paolo to invest in the construction of what turned out to be a fake airport in Abuja. By 2004, the Brazilian banker had transferred more than $\$ 240$ million (The United Nations Office on Drugs and Crime, 2005). In 2019, the US Federal Bureau of Investigation (FBI) indicted 80 people, including 77 Nigerians, in what was dubbed "the largest case of online fraud in US history" (BBC News, 2019: para. 1). Obinwanne Okeke, who was named by Forbes Magazine as one of the top African entrepreneurs under 30 in 2016, allegedly defrauded a subsidiary of Caterpillar to the tune of $\$ 11$ million (BBC News, 2019). In 2020, Raymond Abbas, popularly known as Hushpuppi, who had 2.4 million Instagram followers, was arrested by United Arab Emirates' (UAE) police in Dubai for charges ranging from money laundering, to scamming, cyber fraud, and hacking. Police found the email addresses of around two million victims and documents showing frauds committed worth $£ 352$ million in Hushpuppi's and his accomplices' possession (Independent, 2020). Internet scams are estimated to yield millions of dollars annually and the United States alone lost $\$ 5$ billion in the 1990s (Ojo and Aghedo, 2013). Nigerian criminal networks operate in diverse countries including the United States, the UK, Canada, Hong Kong, Japan, United Arab Emirates 
and African states. Their activities have dented the image of Nigerians abroad, resulting in reluctance and caution on the part of international investors to engage in partnerships with Nigerians (Campbell, 2019), the embarrassment that Nigerian passport holders suffer at international airports, and anti-Nigerian sentiment across the globe.

As early as the 1990s, the United States recognised Nigeria as the hub of illicit drugs emanating from Asia and Latin America en route to Europe and North America (Bach, 2007). It was noted by da Cruz and Stephens (2010) that Nigeria accounted for a third of the heroin and half the cocaine confiscated by the United States and South Africa, respectively. A report prepared by the International Narcotics Control Board (INCB) in 2012 revealed that Nigeria had the highest level of drug trafficking in West Africa and that around 50 per cent of drug traffickers arrested in Europe were Nigerians (Nwannennaya and Abiodun, 2017). In 2017, the National Drug Law Enforcement Agency of Nigeria reported the arrest of three women at the Murtala Muhammed International Airport, Lagos who were trafficking cocaine to Saudi Arabia (INCB, 2019). In the same year, a Nigerian in possession of 594 packs of wrapped cocaine worth 90,000 Rands was arrested in South Africa (Ettang and Leeke, 2019). Since 2013, the INCB has identified non-medical use of tramadol (an opioid analgesic) as a growing problem, especially in Africa, the Middle East, and South Asia (INCB, 2019). In 2017 alone, 125 tons of tramadol tablets were seized globally with Africa, especially Nigeria and Egypt, accounting for a large chunk (INCB, 2019). Regarding cannabis, Nigeria and Morocco accounted for the largest seizures in Africa (INCB, 2019). Nigerian drug syndicates that manufacture and traffic methamphetamine often target South East Asian states (INCB, 2017). From 1979 to $1988,14,833$ Nigerians were arrested, with 4,574 convictions in countries as diverse as the United States, the UK, Saudi Arabia, Pakistan, India, and Thailand (Ettang and Leeke, 2019). Owoyemi et al. (2015) note that Nigerian criminals are notorious in Malaysia and Indonesia, with their activities often making newspaper headlines. Newspaper reports have shown that many drug syndicates in both states and Asia at large are controlled by Nigerians and their local accomplices.

The negative perceptions resulting from this image crisis have been reinforced in Hollywood movies and series such as The Informant in which the protagonist is scammed by a Nigerian through advance fee fraud and The Philanthropist that portrays Nigeria as a country characterised by kidnappers (Ojo and Aghedo, 2013). Similarly, a South African movie, District 9, depicts Nigerians as gangsters and cannibals. The global reach of these movies means that they can sway the hearts and minds of the global audience. It is thus important that Nollywood, as the most important promoter of Nigeria's cultural soft power, continues to counteract such negative stereotypes. However, in light of anti-Nigerian sentiment across Africa, the extent to which Nollywood has won the hearts and minds of Africans and influenced their mind-set seems to be minimal. Despite the fact that many South Africans and other African nationals watch Nigerian movies, this has not prevented recurrent xenophobic attacks and attitudes against 
Nigerians and anti-Nigerian sentiment across Africa, seen in perceptions of Nigerians as drug dealers and Internet fraudsters. The stories and scenes portrayed in some Nollywood films have compounded the situation. Some promote sexism, patriarchy, homophobia, and witchcraft, creating the impression that Nigeria is an illiberal state and an environment where witchcraft is celebrated. Nigeria's capacity to act as an effective hegemon in Africa with global clout is thus undermined by its negative image that partly arises as a result of drug trafficking, Internet scams, and advance fee fraud.

Attempts have been made by successive administrations to repair the country's battered image, including the re-branding Nigeria project and citizen diplomacy during Presidents Yar'Adua's and Goodluck Jonathan's administrations. The rebranding project with the slogan "Nigeria: Good People, Great Nation" was championed by Dora Akunyili, then Minister of Information and Communication. According to Akunyili the project was "a new chapter in our attempt as a people to take conscious steps at redefining our nation, re-examining our values and character and rededicating ourselves to the ideas of our founding fathers" (Egwemi, 2010: 131). It focuses on perceptions of Nigeria and Nigerians. Citizen diplomacy was popularised by Ojo Maduekwe, then Minister of Foreign Affairs. It aimed to shift Nigeria's foreign policy towards the protection of the interests of Nigerian citizens abroad (Ujara and Ibietan, 2014). Citizen-centred diplomacy was informed by the need to prioritise Nigerian citizens both at home and abroad in the state's foreign policy and counteract anti-Nigerian sentiment across the globe. However, these initiatives have had limited success and Nigerians continue to be deported, dehumanised, and killed across the globe including in Africa in places like Cameroon, South Africa, and Libya. The Nigerian Ministry of Foreign Affairs noted that in mid-2015, 16,250 Nigerians were imprisoned across the globe, with 810 of them facing the death penalty (Premium Times, 2015). By mid-2017, about 4,281 Nigerians had been deported from the United States, Europe, and Africa with a large proportion from South Africa and Libya (This Day, 2017). During the same period, Cameroon's security forces killed 97 Nigerian fishermen in Bakassi Peninsula (BBC News, 2017). Against this backdrop, the relevance of the TAC, the re-branding Nigeria project, citizen diplomacy, and Nollywood remain to be seen.

\section{Boko Haram terrorism}

In light of its successful peacekeeping missions, especially in Liberia and Sierra Leone, Nigeria prides itself as a significant military power and by extension a major peacemaker in Africa and beyond. However, the activities of Boko Haram in the past decade have shattered this posture. Boko Haram's reign of terror has threatened Nigeria's territorial integrity and survival, undermining the country's image as a military force to be reckoned with in Africa. A regional hegemon that derives its influence from its soft power does not pose a threat to its sphere of influence; it guarantees security. As I have argued elsewhere, "this begs the question of hegemony or survival. Does Nigeria desire and have the potential to 
assume a hegemonic role in Africa or is it struggling for domestic survival amidst Boko Haram terrorism?" (Tella, 2017: 118). The group's violent attacks have resulted in over 30,000 deaths and more than three million people have been internally displaced (UNHCR, 2020). In the 2019 global terrorism index, Nigeria was ranked third, only behind Afghanistan and Iraq (Institute for Economics and Peace, 2019). The index also highlights that Nigeria was one of the four states that witnessed a significant increase in the number of deaths arising from terrorism in 2018. The other states are Afghanistan, Mali, and Mozambique (Institute for Economics and Peace, 2019).

It is indeed disturbing that Nigeria that was once perceived as a major military power in Africa has struggled to combat Boko Haram, which was a relatively weak group in 2009. This prompted sect leader, Abubakar Shekau, to ask, "is it not amazing that we, who started with sticks and machetes, are today the biggest headache to the almighty Nigerian soldiers? What a shame!" (Ogunnubi et al., 2017: 457). The apparent weakness of the Nigerian military has been attributed to the reform which it witnessed following the country's return to democratic rule in 1999 that resulted in the compulsory retirement of many senior military officers (Amao and Maiangwa, 2017). The situation is complicated by the graft associated with the procurement of arms that led to the purchase of inferior (Amao and Maiangwa, 2017) and inadequate arms to combat the resilient Boko Haram. Poor equipment and ill-preparedness for the fight against the Islamist sect has led to low morale in the Nigerian military and sparked a protest in 2014 by soldiers' wives who felt that their husbands' lives were being toyed with (Amao and Maiangwa, 2017).

Boko Haram's activities have spread to other West and Central African states, especially Cameroon, Chad, and Niger, exposing Nigeria's incapacity to deal with its domestic security problems. Between 2014 and 2016, Boko Haram was involved in more than 400 attacks in Cameroon, including around 50 suicide bombings, with 92 security forces and 1,350 civilian deaths (Heungoup, 2016). Boko Haram's reign of terror in Cameroon reached its peak in 2014 when the wife of the Deputy Prime Minister, Françoise-Agnès Ali-Moufouri, was kidnapped. A 2017 report by the International Crisis Group revealed that Boko Haram attacks had killed hundreds and displaced more than 100,000 people since 2015 (International Crisis Group, 2017). In March 2020, Boko Haram killed around 100 Chadian soldiers in a seven-hour attack (France 24, 2020). Indeed, Nigeria has lost face in its immediate sub-regions of West and Central Africa. Niger's Defense Minister, Mahamadou Karidjo, asserted that "our soldiers are not like Nigerians. They don't run", and Chad's former Foreign Minister and current Chairperson of the AU Commission, Moussa Faki Mahamat, noted that "the Nigerian Army has not succeeded in facing Boko Haram .... My fondest wish is that they assume their responsibilities ... [o] ur biggest wish is that the Nigerian Army pulls itself together - that it takes responsibility in the towns" (Ogunnubi et al., 2017: 458). Thus, the country that was previously seen as a guarantor of peace has emerged as the foremost source of insecurity in these subregions (Tella, 2017). It is no wonder that Nigeria is ranked the fourteenth most 
fragile state in the world out of 178 countries in the 2020 Fund for Peace's Fragile States Index (The Fund for Peace, 2020).

Nigeria's counter-terrorism tactics have also come under serious scrutiny as they are often marked by human rights abuses such as extrajudicial killings and rape, attracting global condemnation from state and non-state actors, including Transparency International and Human Rights Watch. Human Rights Watch (2015: 8) asserted that:

When the army has acted it has often done so in an abusive manner, rounding up hundreds of men and boys suspected of supporting Boko Haram, detaining them in inhuman conditions, and physically abusing or even killing them. Many other community members have been forcibly disappeared, allegedly by security forces. When Boko Haram suspects escaped in March from a famously abusive detention center, Giwa Barracks, Nigerian security forces reportedly recaptured and summarily executed hundreds of them.

Abuse of human rights in counter-terrorism efforts is counter-productive on many levels as it reveals that the Nigerian government does not take globally accepted human rights seriously and undermines the state's capacity to call for military assistance from its allies who do not want to be seen as complicit in human rights violations (Tella, 2017). While Boko Haram's activities sometimes warrant desperate measures, relegating human rights to the back burner has dented Nigeria's legitimacy. The Buhari administration rose to power on the basis of its campaign promise to defeat the insurgent group against the backdrop of his predecessor's - Goodluck Jonathan - failure, yet the group remains potent in spite of the President's claim that it had been "technically defeated". Buhari's relative success in the fight against Boko Haram is evident in the recovery of territory lost to the group, the relocation of the security forces' operational headquarters from Abuja to Maiduguru, and the disruption of Boko Haram's logistics route (Tella, 2018c). However, the group remains resilient and continues to launch attacks that make both local and international headlines. In June 2020, the sect killed 69 people in Borno State, and it attacked the convoy of the state governor Babagana Zulum in July 2020, suggesting that it remains potent (VOA, 2020; Campbell, 2020). A study by Ezenagu and Enohuean (2017) reveals that earnings from tourism (especially hotels and nature reserves) in the northern part of Nigeria have declined significantly due to fear of Boko Haram.

The influx of Nigerian refugees in neighbouring states such as Cameroon and Niger has further tarnished Nigeria's credibility. While in the past Nigeria offered asylum to many Africans fleeing conflict in places such as Sierra Leone and Liberia, political repression in South Africa and Angola, and economic hardship in states such as Ghana, Benin, Togo, and Cameroon (Ogunnubi et al., 2017), it is increasingly seen as a source of asylum seekers in West and Central Africa. Some of these refugees face dehumanisation and deportation in their host countries. For example, in 2015 Niger deported around 3,000 Nigerian refugees who 


\section{Nigeria}

had to walk to Nigeria, with some dying on the way (Ogunnubi et al., 2017). This redounds to a declining soft power.

\section{Great pozers' influence}

Nigeria's capacity to exercise soft power in Africa has also been undermined by the presence of great powers, especially China, the United States, and France, that wield significant influence on the continent. While Africa was important to the two then superpowers - the United States and the Soviet Union - during the Cold War to contain each other's sphere of influence, the end of the Cold War and the emergence of the US-led unipolar order resulted in Africa declining as a factor in the global powers' geo-political calculus. However, there has been renewed interest in the continent particularly from the early 2000s due to factors such as the fight against terrorism, the rising influence of Africa's regional powers, and the increasing importance of the continent as a market for finished goods that ignited China's interest (Tella, 2016). This has sparked what has been described as another "scramble for Africa" as traditional and new partners including the United States, France, China, Russia, and even Brazil are now looking at how they can benefit from Africa. This has a significant impact on Nigeria's soft power and its capacity to achieve its desired outcomes in its relations with other African states. Abuja not only has to compete with its regional contemporaries such as South Africa, Egypt, and Kenya but also with great and middle powers across the globe. Among these actors, China, the United States, and France pose the most important challenge to Nigeria's capacity to exercise its soft power in Africa.

\section{The United States: North American great power's influence}

In order to remain relevant in Africa, the United States has established a number of programmes on the continent including: the African Growth and Opportunity Act (AGOA); the US African Command (AFRICOM); the President's Emergency Plan for AIDS Relief (PEPFAR); Millennium Challenge Corporation (MCG); Power Africa; and the Young African Leaders Initiative (YALI). AGOA and AFRICOM seem to be the initiatives that most undermine Nigeria's soft power as these programmes seek to promote US economic and security interests in Africa. This undermines Nigeria's economic diplomacy and peacemaking role on the continent. For example, through AGOA, the United States has set the trade agenda between Washington and African states by dictating what Africans should export to the United States. In some instances, it has threatened suspension or removal of states from the benefits of AGOA when Washington's interests are perceived to be undermined. An example is the threat to suspend South Africa in 2015 following Pretoria's reluctance to remove barriers to the import of agricultural products including chicken, pork, and beef from the United States in order to protect local farmers. Another is Rwanda's suspension in 2018 due to the East African state's imposition of restrictions on the importation of 
second-hand clothes from the United States (Frazer, 2018). Nigeria's economic diplomacy in its primary sphere of influence is thus undermined.

The role of AFRICOM in toppling and killing former Libyan leader, Muammar Gaddafi, is an important case of how Nigeria's peacemaking role has been punctured by the US military presence on the continent. The three key goals of AFRICOM are:

1 Collection of information on African military forces and control of information systems used by African military elites;

2 Intellectual intervention via the US AFRICOM Social Science Research Platform;

3 Privatisation of militarism through the integration of private military contractors.

(Campbell, 2017: 59)

Clearly, these goals reflect US security interests that do not necessarily align with Africa's interests. Washington's pursuit of these goals renders any security architecture and regional powers such as Nigeria's role on the continent less potent.

\section{China: Asian great power's influence}

Beijing's growing influence in Africa is demonstrated by China's emergence as Africa's largest trading partner. In 2017, the value of trade between China and Africa was $\$ 148$ billion compared with the United States's $\$ 39$ billion (CNBC, 2019). Beijing is now the major external player in the oil industry in states such as Angola, Nigeria, and Sudan (Tella, 2016). China has conquered the African market through concessional loans, commercial loans, and export buyer's credit that African regional powers like Nigeria do not have the economic muscle to offer their African counterparts; hence the growing influence of the Asian power at the expense of the continent's hegemons.

China's key interests in Africa include:

1 Access to natural resources, particularly oil and gas;

2 Markets for Chinese exports;

3 Political legitimacy in international fora, particularly with regard to China's principle of non-interference, "South-South solidarity", and adherence to the "One China" policy;

4 Prosperity, security, and stability on the continent, both for Africans' wellbeing and to ensure the safety of Chinese investments and continuation of its commercial activities.

(Hanauer and Morris, 2014: 5-6)

It is thus clear that Beijing is primarily concerned with its economic interests and has shown no desire in entrenching fundamental values like democracy, good 


\section{Nigeria}

governance, and human rights. Aside from the obvious challenge China's presence poses to Nigeria's economic diplomacy on the continent, Beijing's "non-interference" policy undermines Nigeria's soft power gambit of democracy promotion and norm entrepreneurship. China's bullying of African states to sever their relations with Taiwan and Tibet fits this context. As I have argued elsewhere:

China's incursions in Africa undermine Nigeria's hegemony in two significant respects. Firstly, robust economic relations between China and African countries dictate that Nigeria plays a diminished role in African economies; ... thus cannot lay claim to economic hegemony on the continent. Secondly, China's no-strings attached policy decreases the efficacy of Nigeria's foreign policy of promoting democracy and human rights in Africa.

(Tella, 2019b: 18)

In view of the fact that Beijing often prefers to have bilateral relations with African states rather than multilateral relations at the level of regional organisations like the AU, ECOWAS, and the Southern African Development Community (SADC), Nigeria's efforts as a norm entrepreneur in shaping these organisations and member states is punctured. Nigeria has learned the hard way that it cannot always count on the support of other African states in its middle power ambitions, particularly at the UN Security Council. This was evident in 1977 and 1993 when many African states voted against Nigeria's bid for non-permanent membership of the UN Security Council and in 2009 when her contiguous neighbours including Togo, Liberia, and Sierra Leone did not support a similar bid (Tella, 2019b). However, China has benefitted from the support of African states in pursuit of its great power ambitions, especially in multilateral forums. This is exemplifiedby its replacement of Taiwan on the UN Security Council in 1972 with the support of 26 African states that constituted 34 per cent of the UN General Assembly votes (Bhagawati, 2018). Beijing has also relied on the support of the 54 African states which account for over a quarter of UN members on issues ranging from human rights, to reform of the UN Security Council, and the Tibet question (Sun, 2014).

\section{France: European great power's influence}

France's interest in maintaining a strong relationship with its erstwhile colonies in West Africa in the areas of trade, education, finance, natural resources, and security is in direct conflict with Nigeria's interest that considers the sub-region as its primary sphere of influence. The tensions between the two states date back to 1961 when Nigeria broke diplomatic relations with France following the latter's testing of an atomic bomb in the Sahara. This resulted in France supporting Biafra against the Nigerian state during the country's civil war between 1967 and 1970 (Fawole, 2003). France has continued to support anything that could lead to the break-up of Nigeria. For example, Paris supported Cameroon in its territorial dispute with Nigeria over the Bakassi Peninsula. France's influence in West 
Africa has arguably been the most significant threat to Abuja's capacity to exercise its soft power. Examples include the 2010 Ivorian crisis, which erupted as a result of incumbent President Laurent Gbagbo's rejection of the electoral commission's verdict that declared Alassane Ouattara president. Nigeria's failure to respond swiftly prompted France to remove Gbagbo from power (Zondi, 2015). Paris also played significant roles in the conflicts in Libya in 2011, Mali in 2013, the Central African Republic (CAR) in 2013, and in the ongoing counterterrorism operation in the Sahel region (Recchia, 2020). France's position in Africa rests on its military agreement with around 40 African states that guarantees a permanent French military presence on the continent (Sundberg, 2019) and undermines Nigeria's hegemonic role in West Africa and on the wider continent. It is worth noting that France has always enjoyed a military presence in Africa and was fondly referred to as "Africa's gendarme" during the Cold War. It has deployed its military personnel in more than 130 peacekeeping efforts, mostly in its erstwhile colonies (Sundberg, 2019). Given these efforts, combined with the offer of military training and arms to some African states, many of its former colonies modelled their security sector on the French system (Sundberg, 2019). This again dilutes Nigeria's soft power and influence in the security architecture of West African states.

Aid is another means by which Paris has significantly punctured Abuja's soft power in West Africa. Sub-Saharan Africa accounts for 41 per cent of French aid, making Paris the one who pays the piper and thus calls the tune. While aid has been one of the significant sources of Nigeria's soft power in Africa, increasing domestic imperatives and pressure from civil society actors and Nigerian citizens mean that Abuja no longer has the wherewithal to provide the aid required by its West African neighbours, opening the door to France to exercise soft power in this arena. Therefore, Nigeria's soft power loss in providing aid is France's soft power gain. Indeed, France's influence in Africa, coupled with its nuclear armament, and permanent membership of the UN Security Council, are critical to its great power status (Recchia, 2020). The French-imposed currency CFA (Communauté Financière Africaine) remains the legal tender in France's former colonies in West Africa despite a Nigerian-led ECOWAS initiative to adopt the Eco as the common currency in the sub-region.

\section{Note}

1 Naïa swagger is used here to refer to Nigeria's brands and pop culture including its multinational corporations, literature, fashion, movies, music, and other entertainments.

\section{References}

Adebajo, A. (2013). "A Chance for Nigeria and SA to Upstage PaxGallica." Business Day October 15. https://www.businesslive.co.za/bd/opinion/columnists/2013-10-15-a-cha nce-for-nigeria-and-sa-to-upstage-pax-gallica/. 


\section{Nigeria}

Adebajo, A. (2017). "Nollywood: One of the Few True Representations of 'Global Africa'." 25 May. https://www.iol.co.za/news/opinion/nollywood-one-of-the-fewtrue-representations-of-global-africa-9342934.

Adebanwi, W. (2011). Globally Oriented Citizenship and International Voluntary Service: Interrogating Nigeria's Technical Aid Corps Scheme. Discussion Paper 71. Uppsala: Nordiska Uppsala, Afrikainstitutet.

Adebanwi, W. and Obadare, E. (2011). "When Corruption Fights Back: Democracy and Elite Interests in Nigeria's Anti-Corruption War." The Fournal of Modern African Studies 49 (2): 185-213.

Agbaje, A. and Adejumobi, S. (2006). "Do Votes Count? The Travails of Electoral Politics in Nigeria." Africa Development XXXI (3): 25-44.

Akinola, A. (2019). Nigeria and South Africa in Sub-Regional Peace and Security Agenda: A Comparison. In: Tella, O. (ed.), Nigeria-South Africa Relations and Regional Hegemonic Competence. Cham: Springer, pp. 163-182.

Alli, W. (2012). The Role of Nigeria in Regional Security Policy. Abuja: Friedrich-Ebert-Stiftung, Regional Office.

Amao, O. and Maiangwa, B. (2017). "Has the Giant gone to sleep? Re-assessing Nigeria's response to the Liberian Civil War (1990-1997) and the Boko Haram insurgency (2009-2015)." African Studies 76 (1): 22-43.

Bach, D. (2007). "Nigeria's 'Manifest Destiny' in West Africa: Dominance without Power." Africa Spectrum 42 (2): 301-321.

Bakare, O. and Read, R. (2019). "The Nigerian-Commonwealth and UN relations: Nigeria, from Pariah state to exporter of democracy since 1999." Cogent Social Sciences 5 (1): 1-13.

Bamidele, O. (2015). "Nigeria: A Quest for a Permanent Seat in the United Nations Security Council." Conflict Studies Quarterly 13: 41-57.

BBC News (2010). "How Nigeria Has Affected the Rest of Africa." September 30. http:// www.bbc.co.uk/news/world-africa-11429067.

BBC News (2016). "David Cameron calls Nigeria and Afghanistan 'Fantastically Corrupt'." May 10. https://www.bbc.com/news/uk-politics-36260193.

BBC News (2017). “Cameroon Forces 'Kill 97 Nigerian Fishermen' in Bakassi.” July 14. http://www.bbc.com/news/world-africa-40607306.

BBC News (2019). "Letter from Africa: Why Nigeria's Internet Scammers are 'role models"." https://www.bbc.com/news/world-africa-49759392.

Bhagawati, J. (2018). China's Growing Influence in Africa: Lessons for India. New Delhi: National Maritime Foundation.

Bloomberg (2015). "Bloomberg Markets 50 Most Influential." http://www.bloomberg. com/features/2015-markets-most-influential/\#intro. Accessed 15 February 2016.

Brand Africa (2015). Brand Africa 100: Africa's Best Brands. Gauteng: Brand Africa.

Brand Africa (2020). "Brand Africa 100." https://www.brandafrica.net/Rankings.aspx.

Burgess, S. (2020). "The Foreign Policies of Large Democratizing African States: South Africa and Nigeria." Journal of European, Middle Eastern, \& African Affairs 2 (1): 98-129.

Campbell, H. (2017). "The United States and Security in Africa: The Impact of the Military Management of the International System." Africa Development XLII (3): 45-71.

Campbell, J. (2018). "Nigerians' Growing Cultural Influence Around the World." 7 November. https://www.cfr.org/blog/nigerians-growing-cultural-influence-around-world.

Campbell, J. (2019). "U.S. Arrests Celebrated Nigerian Entrepreneur for Fraud. Council on Foreign Relations." https://www.cfr.org/blog/us-arrests-celebrated-nigerian-entrep reneur-fraud. 
Campbell, J. (2020). "Borno Governor Survives Boko Haram Attack in Nigeria." Council on Foreign Relations, 5 August. https://www.cfr.org/blog/borno-governor-survives-boko-ha ram-attack-nigeria.

CNBC (2019). "The US-China Trade Rivalry is Underway in Africa, and Washington Is Playing Catch-up." https://www.cnbc.com/2019/10/09/the-us-china-trade-rivalry-i s-underway-in-africa.html.

Coaston, J. and O’Donnell, B. (2016). "Africa Specific: Jidenna, Turning up the Volume on Afrobeats." MTV newes 10 May. http://www.mtv.com/news/2940072/african-speci fic-jidenna-turning-up-the-volume-on-afrobeats/.

da Cruz, J. and Stephens, L. (2010). "The U.S. Africa Command (AFRICOM): Building Partnership or Neo-colonialism.” Journal of Third World Studies 27 (2): 193-213.

Dauda, B. (2017). "African Humanism and Ethics: The Cases of Ubuntu and Omolúwàbí." In: Afolayan, A. and Falola, T. (eds), The Palgrave Handbook of African Philosophy. London: Palgrave, pp. 475-492.

Directorate of Technical Aid Corps (2020). "Goals and Objectives of the Technical Aid Corps Scheme." http://www.dtac.gov.ng/DTAC/dtac/aboutDTAC\#first.

Ebegbulem, J. (2011). "Nigeria and Conflict Resolution in Africa: The Darfur Experience." Civilizar 11 (21): 69-76.

Egwemi, V. (2010). "Managing Nigeria's Image Crisis: Akunyili's Rebranding Programme to the Rescue (?)." Current Research Fournal of Economic Theory 2 (3): 131-135.

Ernst and Young (2015). Cultural Times: The First Global Map of Cultural and Creative Industries. London: Ernst and Young.

Ettang, D. and Leeke, N. (2019). "Africa's Emerging Giants and the Drug Scourge: Exploring a Nigeria-South African Bilateral Partnership.” In: Tella, O. (ed.), Nigeria-South Africa Relations and Regional Hegemonic Competence. Cham: Springer.

Ezenagu, N. and Enohuean, E. (2017). "Public Perception of Boko Haram Insurgency on Destination Image and Tourist Flow in Northern Nigeria." African Fournal of Hospitality, Tourism and Leisure 6 (4): 1-14.

Fawole, A. (2003). Nigeria's External Relations and Foreign Policy under Military Rule, 1966-1999. Ile-Ife: Obafemi Awolowo University Press.

Forbes (2020). "World's Billionaires List: The Richest in 2020.” https://www.forbes.com/ billionaires/.

France 24 (2017). "Nigerian Artists Davido, Wizkid Taking Afrobeats to Next Level." 9 November. https://www.france24.com/en/20171109-nigerian-artists-davido-wizkid-ta king-afrobeats-next-level.

France 24 (2020). "Boko Haram Kills Almost 100 Soldiers in Seven-Hour Attack in Chad." https://www.france24.com/en/20200325-boko-haram-kills-almost-100-soldier s-in-a-seven-hour-attack-in-chad.

Frazer, G. (2018). “America's Petty Policy on Used Clothes for Africa.” 17 April. The Conversation. https://theconversation.com/americas-petty-policy-on-used-clothes-for-africa-95132.

Freedom House (2020). "Freedom in the World 2020." https://freedomhouse.org/coun tries/freedom-world/scores.

Giorgis, H. (2019). "The 'African Giant' Challenging Musical Boundaries." The Atlantic. https://www.theatlantic.com/entertainment/archive/2019/07/burna-boy-african-gian t-bombastic-nigerian-pop/594610/.

Hamman, S. and Omojuwa, K. (2013). "The Role of Nigeria in Peacekeeping Operations from 1960 to 2013." Mediterranean Fournal of Social Sciences 4 (16): 27-32.

Hanauer, L. and Morris, L. (2014). Chinese Engagement in Africa Drivers, Reactions, and Implications for U.S. Policy. Washington, DC: Rand Corporation. 
Hartmann, C. (2017). "ECOWAS and the Restoration of Democracy in The Gambia." Africa Spectrum 52 (1) 85-99.

Heungoup, H. (2016). "Q\&A: Boko Haram in Cameroon." International Crisis Group, 6 April. https://www.crisisgroup.org/africa/central-africa/cameroon/q-boko-haram-cam eroon.

Hulse, M. (2016). Regional Powers and Leadership in Regional Institutions: Nigeria in ECOWAS and South Africa in SADC. Kolleg-Forschergruppe (KFG) Working Paper Series. Berlin: Kolleg-Forschergruppe.

Human Rights Watch (2015). World Report: Events of 2014. New York: Human Rights Watch.

Independent (2020). "Instagram Influencer 'Hushpuppi' Arrested Amid Claims of $£^{350 m i l-}$ lion Global Cyberscam." 29 June. https://www.independent.co.uk/news/world/m iddle-east/hushpuppi-instagram-news-arrested-cyberscam-350-million-a9590826.html.

Institute for Economics and Peace (2019). "Global Terrorism Index 2019: Measuring the Impact of Terrorism.” http://visionofhumanity.org/reports.

International Crisis Group (2017). "Fighting Boko Haram in Chad: Beyond Military Measures." 8 March. Report No. 246. https://www.crisisgroup.org/africa/central-a frica/chad/246-fighting-boko-haram-chad-beyond-military-measures.

International Narcotics Control Board (INCB) (2017). Report of the International Narcotics Control Board for 2017. Vienna: International Narcotics Control Board.

International Narcotics Control Board (INCB) (2019). Report of the International Narcotics Control Board for 2019. Vienna: International Narcotics Control Board.

Jewell, G. (2019). "iROKOtv: Delivering Nollywood Content to the World." WIPO Magazine. https://www.wipo.int/wipo_magazine/en/2017/05/article_0002.html.

Jinadu, A. (2016). "South-South Cooperation in the African Region: Case Study of Nigeria's Technical Aid Corps (TAC)." Fournal of International Politics and Development $14(1): 1-39$.

Krings, M. and Simmert, T. (2020). "African Popular Culture Enters the Global Mainstream." Current History 119 (817): 182-187.

Kuna, M. (2005). "The Role of Nigeria in Peace Building, Conflict Resolution, and Peacekeeping since 1960." A Paper Presented at the Workshop on Nigeria and the Reform of the United Nations, Organised by the Centre for Democratic Development, Research and Training, Hanwa, Ahmadu Bello University, Zaria.

Mail \& Guardian (2019). "What Netflix's Involvement in Nigeria's Massive Film Industry Really Means." 3 January. https://mg.co.za/article/2019-01-03-what-netflixs-involvem ent-in-nigerias-massive-film-industry-really-means/.

McBain, W. (2019). "Canal+ and Netflix Eye Nollywood Opportunities." African Business 24 October. https://africanbusinessmagazine.com/region/canal-and-netflix-eye-nollywood -opportunities/.

Miller, J. (2012). "Global Nollywood: The Nigerian Movie Industry and Alternative Global Networks in Production and Distribution." Global Media and Communication 8 (2): $117-133$.

Mimiko, N. O. (2017). "The Omoluabi Essence: An Interrogation of the History, Culture, and Identity of the Yoruba in Transitory Contexts." African and Asian Studies 16 (3): 243-258.

MTV Africa (2015). MAMA 2015 Awards. http://mama.mtv.com/news/2015-mtv-africa -music-awards-winners/.

Muhammad, A and Salawu, I. (2020). "Corruption and Nigeria's External Image in the Fourth Republic.” Journal of Management and Social Sciences 9 (1): 784-801. 
Norbrook, N. (2020). "Nigeria's Musical Moment." The Africa Report, 6 January. https:// www.theafricareport.com/21775/nigerias-musical-moment/.

Nwannennaya, C. and Abiodun T. (2017). "Illicit Drug Trafficking in Nigeria: Obstacle to National Development and Security." Journal of Political Science and Public Affairs 5 (1): $1-6$.

Nye, J. (2004). Soft Power: The Means to Success in World Politics. New York: Public Affairs.

Obi, C. (2009). "Economic Community of West African States on the Ground: Comparing Peacekeeping in Liberia, Sierra Leone, Guinea Bissau, and Côte d'Ivoire." African Security 2 (2/3): 119-135.

Offiah, C. (2017). "Globalization and the Culture/Creative Industries: An Assessment of Nigeria's Position in The Global Space." IOSR Joumal of Humanities and Social Science 22 (1): 11-23.

Ogbonna, C. and Ogunnubi, O. (2018). "Rethinking the Role of Nigeria's Technical Aid Corps as Soft Power: Rough Diamond or Fools' Gold." Ubuntu: Fournal of Conflict and Social Transformation 7 (2): 121-141.

Ogunbadejo, O. (1980). "Nigeria's Foreign Policy under Military Rule 1966-79." International foumal 35 (4): 748-765.

Ogunnubi, O. and Isike, C. (2015). "Regional Hegemonic Contention and the Asymmetry of Soft Power: A Comparative Analysis of South Africa and Nigeria." Strategic Review for Southern Africa 37 (1): 152-177.

Ogunnubi, O. and Isike, C. (2018). "Nigeria's Soft Power Sources: Between Potential and Illusion?" International Fournal of Politics, Culture and Society 31 (1): 49-67.

Ogunnubi, O., Onapajo, H. and Isike, C. (2017). "A Failing Regional Power? Nigeria's International Status in the Age of Boko Haram." Politikon 44 (3): 446-465.

Oh, E. (2014). "Nigeria's Film Industry: Nollywood Looks to Expand Globally." Executive Briefings on Trade, United States International Trade Commission.

Ojo, G. and Aghedo, I. (2013). "Image Re-branding in a Fragile State: The Case of Nigeria." The Korean Fournal of Policy Studies 28 (2): 81-107.

Ojo, O. (1980). "Nigeria and the Formation of ECOWAS." International Organization 34 (4): 571-604.

Okayafrica (2016). "The Full List of MTV Africa Music Awards 2016 Winners." https:// www.okayafrica.com/mtv-africa-music-awards-2016-winners-mtvmama2016/.

Olanipekun, O. (2017). "Omoluabi: Re-thinking the Concept of Virtue in Yoruba Culture and Moral System.” Africology: The Fournal of Pan African Studies 10 (9): 217-231.

Omo-Ogbebor, D. (2017). "Nigerian Foreign Policy Approach towards ECOWAS." International Fournal of Human Sciences 14 (4): 4015-4022.

Omotola, S. (2008). "From Importer to Exporter: The Changing Role of Nigeria in Promoting Democratic Values in Africa." In: Pretorius, J. (ed.), African Politics: Beyond the Third Wave of Democratisation. Cape Town: Juta and Company, pp. 33-51.

Onapajo, H. (2017). "Has Nigeria Defeated Boko Haram? An Appraisal of the Counter-Terrorism Approach under the Buhari Administration." Strategic Analysis 41 (1): $61-73$.

Onishi, N. (2016). "Nigeria's Booming Film Industry Redefines African Life." The New York Times, 18 February. https://www.nytimes.com/2016/02/19/world/africa/with-a -boom-before-the-cameras-nigeria-redefines-african-life.html.

Oshewolo, S. (2019a). "Rhetoric and Praxis: Nigeria's Africa Diplomacy and the Shaping of the African Union" The Round Table 108 (1): 49-65.

Oshewolo, S. (2019b). "A Reconsideration of the Afrocentric Principle in Nigeria's Foreign Policy Framework.” Geofournal, https://doi.org/10.1007/s10708-019-10114-1. 
Osondu, M. (2015). "Membership in the Militalaterial Economic Organizations: An Evaluation of Nigeria's Participation in ECOWAS (1985-2014)." International Fournal of Development and Management Review 10 (1): 95-109.

Osuntokun, A. (2008). "Gulliver and the Lilliputians: Nigeria and Its Neighbours." In: Adebajo, A. and Mustapha, A. (eds), Gulliver's Troubles: Nigeria's Foreign Policy after the Cold War. KwaZulu-Natal: University of KwaZulu-Natal Press, pp. 141-159.

Owoyemi, M., Din, A. and Ahmad, Z. (2015). “The Diaspora Nigerians' Image Problem of Drug and Fraud: A Case Study of the Malaysian-Indonesian Experience through Newspaper Reports." Fournal of Social Sciences 11 (2): 55-71.

Premium Times (2015). "How Nigerian Govt. Is Abandoning Its Citizens on Death Row Abroad.” June 27. Accessed 10 November 2017. https://www.premiumtimesng.com/ features-and-interviews / 185721-how-nigerian-govt-is-abandoning-its-citizens-on-death-r ow-abroad.html.

PricewaterhouseCoopers (2016). Impact of Corruption on Nigeria's Economy. PricewaterhouseCoopers.

PricewaterhouseCoopers (2017a). The Business of Entertainment Harnessing growth opportunities in Entertainment, Media, Arts and Lifestyle. PricewaterhouseCoopers.

PricewaterhouseCoopers (2017b). Spotlight: The Nigerian Film Industry. PricewaterhouseCoopers.

Recchia, S. (2020). "A Legitimate Sphere of Influence: Understanding France's Turn to Multilateralism in Africa." Fournal of Strategic Studies 43 (4): 508-533.

Saliu, H. and Omotola, S. (2008). "Can Nigeria Get a UN Security Council Seat?" South African Fournal of International Affairs 15 (1): 71-85.

Sanda, J. (2012). "Nigeria's Global Role in Peacekeeping: From the Congo through Lebanon to Bosnia Herzegovina." In: Jega, A. and Farris, J. (eds), Nigeria at Fifty: Contributions to Peace, Democracy, and Development. Abuja: Shehu Musa Yar'Adua Foundation, pp. 79-98.

Sun, Y. (2014). Africa in China's Foreign Policy. John L. Thornton China Center and the Africa Growth Initiative at Brookings.

Sundberg, A. (2019). France - A Continuing Military Presence in Francophone Africa. Stockholm: Swedish Defence Research Institute.

Tella, O. (2016). "Wielding Soft Power in Strategic Regions: An Analysis of China's Power of Attraction in Africa and The Middle East." Africa Review 8 (2): 133-144.

Tella, O. (2017). "Attractions and Limitations of Nigeria's Soft Power." Fournal of Global Analysis 7 (2): 109-128.

Tella, O. (2018a). "Agenda 2063 and Its Implications for Africa's Soft Power." Journal of Black Studies 49 (7): 714-730.

Tella, O. (2018b). "Is Nigeria a Soft Power State?" Social Dynamics 44 (2): 376-394.

Tella, O. (2018c). "Boko Haram Terrorism and Counter-Terrorism: The Soft Power Context." Fournal of Asian and African Studies 53 (6): 815-829.

Tella, O. (2019a). Revisiting the Georgetown Agreement: Comparative Region-building in Africa, the Caribbean, and the Pacific. Policy Brief 4. Johannesburg: Institute for Pan-African Thought and Conversation.

Tella, O. (2019b). "Internal, Regional and External Impediments to Nigeria and South Africa's Hegemonic Competence in Africa." In: Tella, O. (ed.), Nigeria-South Africa Relations and Regional Hegemonic Competence. Cham: Springer.

The Economist Intelligent Unit (2020). Democracy Index 2019: A Year of Democratic Setbacks and Popular Protest. London: The Economist Intelligent Unit.

The Fund for Peace (2020). Fragile States Index Annual Report 2020. Washington, DC: The Fund for Peace. 
This Day (2017). “4,281 Nigerians Deported from Europe, US, African Countries Mid 2017." October 9. https://www.thisdaylive.com/index.php/2017/10/09/4281-nigeria ns-deported-from-europe-us-african-countries-mid-2017/.

Tieku, T. (2004). "Explaining the Clash and Accommodation of Interests of Major Actors in the Creation of the African Union." African Affairs 103 (411): 249-267.

Transparency International (2016-2020). "Corruption Perceptions Index." https://www. transparency.org/en/cpi.

Ujara, E. and Ibietan, J. (2014). "Citizen Diplomacy and Nigeria's International Image: The Social Constructivist Explanation." Covenant Fournal of Business and Social Sciences 6 (2): 40-57.

Umezurike, S. Iwu, C. Asuelime, L. and Umezurike, C. (2017). "Re-examining Nigeria's Contributions to the African Union and the Domestic Socio-Economic Ramifications." Fournal of Economics and Behavioral Studies 9 (1): 17-26.

UNHCR (2020). "UNHCR Outraged by Attack on Camp Hosting Displaced People in Cameroon, at Least 18 People Killed." 4 August. https://www.unhcr.org/news/brief ing/2020/8/5f291a704/unhcr-outraged-attack-camp-hosting-displaced-people-cameroo n-18-people.html.

United Nations Office on Drugs and Crime (2005). Transnational Organized Crime in the West African Region. New York: The United Nations.

United Nations Office on Drugs and Crime (2019). Corruption in Nigeria: Patterns and Trends: Second Survey on Corruption as Experienced by the Population. New York: United Nations.

VOA (2020). "69 People Killed in Nigerian Village by Suspected Boko Haram Militants." 10 June. https://www.voanews.com/africa/69-people-killed-nigerian-village-suspectedboko-haram-militants.

Zondi, S. (2015). "Africanity, Pan-Africanism and African renaissance: South Africa's Africa agenda under Mbeki and Zuma." In Masters, L., Zondi, S., and van Wyk, J. (eds), South African Foreign Policy Review (Vol. 2, pp. 97-118). Pretoria: Africa Institute of South Africa. 


\title{
4 South Africa
}

\author{
Mzansi symbolism
}

\section{Introduction}

The end of apartheid in 1994 and South Africa's subsequent integration in the international system presented a platform for the state to exhibit its soft power capability. Given the international isolation and ignominy Pretoria suffered during apartheid, partly due to the regime's heavy reliance on hard power evident in the destabilisation of neighbouring states, the new South Africa had to convince the world that things would be done differently.

Early positive signals of the exercise of soft power included South Africa's nuclear disarmament, the larger than life character of Nelson Mandela, the constitutional order, and the success of the Truth and Reconciliation Commission (TRG). This instant soft power display provided the launch pad for South Africa to exhibit other dimensions of its soft power, including: its cultural output in the form of its entertainment industry, sporting events, and educational exchange; Ubuntu and multilateral diplomacy; peace diplomacy and democracy promotion; as well as the soft power exercised by the country's non-state actors including its Civil Society Organisations (CSOs), multinational corporations (MNCs), and universities. With this soft power advantage, South Africa emerged as a regional power with remarkable global influence, seen in its "symbolic representivity" of Africa in international organisations such as the emerging economies of Brazil, Russia, India, China, and South Africa (BRICS), the India-Brazil-South Africa Dialogue Forum (IBSA), and the Group of Twenty (G20) (Alden and Schoeman, 2015).

However, after more than two-and-a-half decades of majority rule, South Africa seems to have lost its edge in Africa due to the constraints and contradictions that have dampened its soft power currencies. These include: the economic challenges of poverty, unemployment, and inequality; the political brouhaha of corruption, state capture, and party politics; and South Africa's double standards on human rights, as well as incessant xenophobic incidents. The effect of these bottlenecks is seen in the increasing decline of the state's influence in regional and international affairs. This implies that Mzansi (as the country is often called among South Africans) needs to address these constraints in order to be able to optimise the effectiveness of its soft power and, ultimately, to once again punch above its weight in international affairs.

DOI: $10.4324 / 9781003176022-4$ 


\section{Sources of South Africa's soft power}

\section{Entertainment, sporting events, and educational exchange}

\section{Music and soap operas}

In terms of its cultural output, South Africa's entertainment industry, particularly music and movies, prestigious universities, the hosting of international sporting events, and the spread of its MNCs across Africa, are germane. South Africa is an important source of entertainment in Africa and its major cities including Johannesburg, Durban, and Cape Town are hubs for music artists across Africa for the production of their music videos. Through a South African owned satellite television channel, DStv, the country transmits its music and other cultural exports to the African people, with the result that some have embraced the South African culture. For instance, the South African dance move Gwara Gwara has gone viral on the continent and beyond, with popular US artist Rihanna dancing it at the 2018 Grammy Awards. Other American artists to follow suit include Chris Brown in Blow my Mind and Childish Gambino in This is America. The coronavirus disease (COVID-19) has presented an incredibly difficult time. However, many people across the world have found solace in the South African hit song Jerusalema, which at the time of writing had over 370 million views on YouTube and culminated in the popular dance challenge, \#JerusalemaChallenge.

DStv also provides an avenue for South Africa to showcase its pool of talent to its African audience (Ogunnubi and Okeke-Uzodike, 2015) thereby enhancing the profile of South African movie artists such as Sello Maake Ka-Ncube, Leleti Khumalo, Leon Schuster, Jamie Bartlet, Moshidi Motshegwa, Pearl Thusi, Nomzamo Mbatha, and music artists like Miriam Makeba, Hugh Masekela, Brenda Fassie, Yvonne Chaka Chaka, Lucky Dube, AKA, Cassper Nyovest, Kwesta, Black Coffee, DJ Maphorisa, Busiswa, and Lira.

These artists provide South Africa with a reservoir of talent to deploy celebrity diplomacy on the continent and are critical in influencing the hearts and minds of the African public through social media networks, particularly Twitter and Facebook. It is for this reason that South Africa has excelled in African music awards, only being outshone by Nigeria. Tables 4.1 and 4.2 show the MTV Africa Music Awards (MAMA) won by South African artists in 2015 and 2016 before the awards were halted in 2016. In 2016, Black Coffee was the first South African to win a Black Entertainment Television (BET) award, having been awarded the Best International Act - Africa. In 2018, Sjava won the BET Award for the Viewers' Choice Best International Act, while Sho Madjozi won the Best New International Act Award in 2019.

South Africa's soap operas such as Generations, Scandal, Rhythm City, and The River are popular across the continent and account for a significant portion of viewers' television time. These popular soaps serve as an important channel to transmit the South African way of life to other African states and have been 
Table 4.1 2015 MAMA awards

\begin{tabular}{ll}
\hline Award & Artist \\
\hline Best hip hop & Cassper Nyovest \\
Video of the year & Riky Rick (Nafukwa) \\
Best pop and alternative & Jeremy Loops \\
Best collaboration & AKA, Da LES, JR and Nigerian Burna \\
& Boy (All Eyes on Me) \\
Personality of the year & Trevor Noah \\
\hline
\end{tabular}

Source: author's adaptation from MTV Africa, 2015.

Table 4.2 2016 MAMA AWARDS

\begin{tabular}{ll}
\hline Award & Artist \\
\hline Best live act & Cassper Nyovest \\
Best hip hop & Emtee \\
Best pop and alternative & Shekinah and Kyle Deutsch \\
Personality of the year & Caster Semenya \\
Legend award & Hugh Masekela \\
Best collaboration & DJ Maphorisa, DJ Buckz, and Nigerian \\
& Wizkid (Soweto Baby) \\
\hline
\end{tabular}

Source: author's adaptation from Okayafrica, 2016.

successful in challenging African societal stereotypes such as homophobia, gender discrimination, and patriarchy (Ogunnubi and Okeke-Uzodike, 2015). Beyond entertainment, they serve as a veritable platform to enhance national unity by addressing South Africa's apartheid past and highlighting transformation efforts towards a multicultural democracy in contemporary South Africa (Barnard, 2006; Ives, 2007). For example, Isidingo, one of the popular South African soap operas, has in the past transmitted the emotional process that characterised the TRC, which held hearings into human rights abuses and political violence in apartheid South Africa (Barnard, 2006). The TRG has since become a model for states around the world. South African soap operas like 102 Paradise Complex and Isidingo have also engaged the issues of race, racism, and identity in the post-apartheid era (Barnard, 2006).

South African soap operas also showcase the cultural diversity of the postapartheid era, especially to their African audience. The South African constitution recognises 11 official languages including isiXhosa, isiZulu, Sepedi, Sesotho, Setswana, siSwati, Tshivenda, Xitsonga, Afrikaans, English, and isiNdebele. In soap operas like Generations, The River, Gomora, Rhythm City, The Queen, and Scandal, the characters often communicate with one another in different languages and a scene may feature different characters, with each communicating in a different language. The soap operas thus present an image of a thriving multicultural state 
to the African audience in an era of increasing cleavages along ethnic and racial lines. In addition, South African soap operas often challenge the hegemonic standards and monolithic story lines that characterise African cinema. For example, The Queen portrays different shades of masculinity as opposed to the traditional depiction of masculinity and manhood (Ncube, 2019). While the character of Brutus Khoza evinces brute masculinity, Jabulani, also known as Mjekejeke, symbolises traditional masculinity in view of the fact that he positions himself as the head of his household; Shaka Khoza represents a violent or militarised masculinity; Kagiso Khoza epitomises tough but sober masculinity; and Kgosi, Prince, and Schumacher portray gay masculinity with Schumacher playing the part of a bisexual (Ncube, 2019). It is thus clear that the South African constitution that is celebrated as one of the most progressive in the world due to its focus on multiculturalism, equality, and freedom of expression, has had a significant influence on the production of soap operas.

\section{Sporting events}

Participating in and/or hosting major sporting events presents an opportunity for states to subtly reiterate their stances on global issues. For example, international ostracism of apartheid South Africa barred the country from participating in and hosting sporting events. Sport not only serves as a veritable tool to enhance nation building, it also provides the platform for a state to showcase its identity and culture on the international stage (Grix and Lee, 2013) through the criss-crossing of sport, politics, and diplomacy. Hosting international, particularly mega or major, sporting events such as the Fédération Internationale de Football Association (FIFA) World Cup and the Olympic Games thus provides instant global visibility. In the postapartheid period, South Africa has leveraged on the soft power benefits that the hosting of sporting events presents. South Africa hosted the 1995 Rugby World Cup (and won it), the 2003 Cricket World Cup, and the 2010 FIFA World Cup. Although the double disappointment of its loss of bids to host the 2022 Commonwealth Games and 2023 Rugby World Cup lingers, there is no doubt that the country enhanced its international prestige through the successful hosting of previous events. While the 1995 Rugby World Cup signified South Africa's integration into the international system after decades of isolation, the 2003 Cricket World Cup highlighted democratic consolidation in the relatively new state; and the 2010 FIFA World Cup showcased South Africa as an emerging power in the international system. The significance of the 1995 Rugby World Cup stems from its utility in promoting the notion of a Rainbow Nation to the outside world. Rugby is widely perceived as a white sport in South Africa. Given that it was the first significant sporting event in the post-apartheid era, it presented an opportunity for the Mandela administration to unite the newly democratic, racially divided country. Fortunately, the trophy was won by South Africa. Mandela's symbolic gesture of wearing the rugby team's (Springbok) jersey when he presented the trophy to white team captain Francois Pienaar captured the imagination of the country and the world (Freeman, 2012). 
The 2010 FIFA World Cup in particular seems to have been the most spectacular event to provide a platform for public diplomacy. This is due to the impressive number of soccer fans. For example, the final match between Spain and the Netherlands was estimated to have been watched by 700 million people (Dowse, 2011). The FIFA World Cup presents an opportunity to attract global attention to the host country's culture, values, infrastructure, and by extension, soft power. Aside from the fact that the host state enjoys instant global visibility, other advantages include national pride, the rise of the tourism sector, and increased trade and flow of investment (Grix and Lee, 2013). South Africa was and remains the only African country to have hosted this event. Perceptions of Africa as the land of diseases, terrorism, war, corruption, bad governance, and poor infrastructure and attendant global pessimism were debunked through South Africa's successful hosting of this spectacle.

Media coverage of the World Cup attracted 46 per cent of the global population, presenting an unparalleled opportunity to exercise public diplomacy (Grix and Lee, 2013). South Africa's portrayal of the 2010 tournament as an African World Cup seems to have won the state valuable kudos. It is against this backdrop that Pretoria consulted the African Union (AU) and the Southern African Development Community (SADG) while bidding for the tournament, which resulted in these organisations' support and commitment to the success of the World Cup (Ndlovu, 2010). In practical terms, the AU "urged its member states to develop national programmes and identify African Union sport ambassadors to help implement the International Year of African Football, 'Sports for All' programmes, and the 2010 FIFA World Cup Legacy Programme" (Ndlovu, 2010: 149). The AU celebrated 2007 as the International Year of African Football in commemoration of the fiftieth anniversary of the Confederation of African Football (CAF) and to highlight solidarity with South Africa in its hosting of the first World Cup on African soil (Ndlovu, 2010). In order to give Southern African states a sense of belonging, representatives from Lesotho, Mozambique, and Eswatini (former Swaziland) were involved in the various committees charged with planning the global spectacle and others such as Angola, Botswana, and Namibia were kept abreast of developments in the planning process (Ndlovu, 2010).

Despite the challenges that characterise contemporary South Africa, including: the triple challenges of poverty, unemployment, and inequality; high levels of HIV/AIDS infection; and a high crime rate, the successful hosting of the tournament enhanced South Africa's international profile and to some extent reinforced its foreign policy objective of acting as a global middle power (Grix and Lee, 2013). Its successful hosting of the event reinforces the fact that South Africa is a regional power and enhances perceptions that it is an emerging power, boosting its credentials for admission to the BRIC countries (Tella, 2017). This prompted then President Jacob Zuma to note that the World Cup was "the greatest marketing opportunity of our time" (Brand South Africa, 2010: para. 4). Beyond hosting international sporting events, Pretoria has offered assistance to a number of African states towards successful hosting of the Africa Cup of Nations 
(AFCON) such as Mali in 2002 and Ghana in 2008; and the country's multinational companies such as MTN (one of the biggest telecommunications companies in Africa), Standard Bank (one of the strongest banks on the continent), and Multichoice Supersport (Africa's leading satellite broadcaster) provide sponsorships and other financial support to African football as well as other sports (Ndlovu, 2010). Pretoria has thus deployed sports diplomacy to promote its foreign policy objectives in Africa and beyond. Hosting international sporting events showcases South Africa as a regional power and a gateway to Africa and offering assistance to fellow African states enhances the country's Afrocentric foreign policy.

\section{Higher education}

It is a truism that South Africa is host to many African migrants. The regional power is also a destination for migrants from further afield including Europe, the Americas, and Asia that are mostly in the country to study, work, or for pleasure. South African universities have positioned themselves as the most sought after institutions in Africa for foreign students and academics. For example, between 2002 and 2012, foreign student enrolment increased from 975 to 4,698. African students alone increased from 573 to 3,901 in the same period. Citizens from the SADC sub-region account for most of the students. However, these institutions also draw many students from other states in Africa, especially Nigeria and the Democratic Republic of the Congo (DRG), and to a lesser extent from Europe and the Americas (Tella, 2018a). This reflects the cutting-edge facilities available in the universities, their remarkable research output, and their impressive standing in global university rankings at least in the African context. The reputation and relative affordability (in comparison with their Western counterparts) of universities such as Cape Town, KwaZulu-Natal, Pretoria, Stellenbosch, and the Witwatersrand have attracted many international students. The tables below list the top universities in Africa.

As Tables 4.3 and 4.4 show, the Universities of Cape Town and the Witwatersrand are ranked the best and second best universities in Africa. South African universities also dominate the top ten universities in Africa. The Times Higher Education ranking has five South African universities while Cybermetrics has eight. Furthermore, South African universities account for the top five universities in Africa in the Cybermetrics Lab ranking and the top three in that of Times Higher Education. These higher education institutions serve as a veritable platform to transmit South African culture and values to international students. Exposure to the country's rich culture exemplified by its racial and ethnic composition and 11 official languages is one of the motivations for international students (Sehoole, 2015). Therefore, South African universities are sites for foreign students to imbibe the country's culture, reinforcing the state's cultural soft power.

These institutions are also sources of export earnings, thereby contributing to national wealth and enhancing South Africa's economic diplomacy. This 
Table 4.3 Times Higher Education top 10 African universities

\begin{tabular}{lll}
\hline University & African rank & World rank \\
\hline University of Cape Town & 1 & 136 \\
University of the & 2 & 194 \\
Witwatersrand & & \\
Stellenbosch University & 3 & $251-300$ \\
Aswan University & 4 & $401-500$ \\
Covenant University & 4 & $401-500$ \\
University of KwaZulu-Natal & 4 & $401-500$ \\
Mansoura University & 4 & $401-500$ \\
University of Ibadan & 8 & $501-600$ \\
North West University & 8 & $501-600$ \\
Suez Canal University & 8 & $501-600$ \\
\hline
\end{tabular}

Source: author's adaptation from Times Higher Education, 2020.

Table 4.4 Cybermetrics Lab top 10 African universities

\begin{tabular}{lll}
\hline University & African Rank & World Rank \\
\hline University of Cape Town & 1 & 265 \\
University of the & 2 & 411 \\
Witwatersrand & 3 & 420 \\
Stellenbosch University & 4 & 440 \\
University of Pretoria & 5 & 606 \\
University of KwaZulu-Natal & 6 & 655 \\
Cairo University & 7 & 777 \\
University of Johannesburg & 8 & 863 \\
University of South Africa & 9 & 909 \\
University of the Western & & 956 \\
Cape & 10 & \\
University of Nairobi &
\end{tabular}

Source: author's adaptation from Cybermetrics, 2020.

prompted Mail \& Guardian journalist, Samantha Spooner, to observe that "foreign students, especially from Africa, have become bread and butter for South Africa's universities and the economy of, especially the country's richest province Gauteng" (Spooner, 2014: para. 7). The critical role played by international students in the sustenance of South African higher education is highlighted in several policy documents including the 2001 National Plan for Higher Education, the 2011 National Development Plan (NDP) 2030, and the 2014 White Paper for Post-School Education and Training; as these students are the life blood of many postgraduate programmes and postdoctoral fellowships in South African universities. Foreign academics also make noteworthy contributions and some have 
added significantly to the research output of South African universities. Cloete et al. (2015) note that universities such as Fort Hare and North West (Mafikeng campus) that have a large number of foreign academics have witnessed an exponential increase in research output and international students. Research output and international outlook (the ratio of international staff and students to their domestic counterparts) are important contributors to university ranking. A major challenge to South African higher education's soft power profile is the incessant xenophobia that has characterised these universities. This manifests in anti-immigrant comments, making fun of foreign accents, exclusionary relationships, and the denial of certain privileges (Singh, 2013).

The NDP Vision 2030 states that "In 2030, 75 percent of University academics should hold PhDs. PhD graduates, either as staff or post-doctoral fellows, will be the dominant drivers of new knowledge production within the higher education and science innovation system" (National Planning Commission, 2011: 267). To achieve this goal, it sets a target of more than 5,000 doctoral graduates annually by 2030 (National Planning Commission, 2011) and calls for ongoing debate on decolonising universities. South Africa still relies heavily on foreign, especially African, academics and postgraduate students due to the current skills shortage. However, the recurrent xenophobia in these institutions tends to discourage international students and academics from enrolling and applying for positions, respectively, and inhibits existing ones in imbibing the culture of their host country. In 2017, at a seminar organised by the Institute of Security Studies in Pretoria, Maxi Schoeman, then deputy dean of the Faculty of Humanities, University of Pretoria, stated that there had been a decline in the enrolment of international students in South African universities as a result of the xenophobic incidents that year (News24, 2017).

Pretoria's other notable cultural attraction is South Africa's firsts. The country prides itself on performing the first human to human heart transplant in the world, producing the first computed axial tomography (CAT) scan machine (Allan Cormack), and being the birthplace of the first African in space (Mark Shuttleworth), the first African to have successfully climbed Mount Everest (Sibusiso Vilane), the first African to have won an Oscar award (Charlize Theron), and of course the first (and only) African state to have hosted the FIFA World Cup.

\section{Liberal values and charismatic leaders}

South Africa can lay claim to impressive soft power attributes in the realm of political values, principally from its liberal constitution, liberal democracy, charismatic leaders and its political settlement (the post-apartheid transition). South Africa's 1996 constitution is widely acclaimed as one of the most progressive in the world as it guarantees residents' socio-economic rights as well as the rights of minority groups such as people with disabilities, children, women, and lesbian, gay, bisexual and transgender (LGBT) people. Its constitutional order gives South Africa the moral authority to promote liberal ideals including democracy and human rights across the globe. 
Another important element of South Africa's soft power in the realm of political values is the international clout of some of its past political leaders such as Nelson Mandela, Thabo Mbeki, Walter Sisulu, Steve Biko, and Oliver Tambo. Leaders such as Tambo and Sisulu sensitised the global audience to the fight against the oppressive apartheid regime. Mandela's larger than life character not only stemmed from his charisma but also his status as a symbol of emancipation, peaceful transformation, and reconciliation. While his fight against the apartheid regime landed him in prison for close to three decades, his conviction that reconciliation was the only route to move the new South Africa forward prevented a possible racial Armageddon and accorded him instant global accolades. This moral authority was significant in South Africa's pursuit of its foreign policy objectives, especially in the areas of human rights and democracy promotion during Mandela's and Mbeki's administrations. Mandela's vigorous pursuit of a democratic and progressive world that respects human rights values prompted Joseph Nye, the doyen of soft power to categorise the South African icon with Mahatma Ghandi and Martin Luther King Jnr., as leaders that had the capacity to determine people's aspirations (Nye, 2012). After Mandela's exit from the political scene, South Africa continued to tap into his reservoir of moral authority to promote its interests. An example was the significant role Mandela played in the awarding of the hosting rights of the 2010 FIFA World Cup to South Africa. His global reach is captured by the fact that around 60 and 70 heads of state and government visited South Africa during his presidency (1994-1999) and attended his funeral in December 2013, respectively (Tella, 2017).

Thabo Mbeki's presidency witnessed a dynamic South African foreign policy rooted in the notion of African Renaissance and found practical expression in the establishment of the New Partnership for African Development (NEPAD) and the African Peer Review Mechanism (APRM), and the transformation of OAU to the AU. Africa's centrality in Mbeki's foreign policy was reflected in his various statements, speeches, and declarations such as the "I am an African" speech in 1996, his speech in 1997 at the launch of a document titled "The African Renaissance: A Workable Dream", and his 1999 inaugural speech on the "African Century" (Masters, 2017). Due to his seeming preference for foreign policy as opposed to domestic policy, Mbeki was often criticised in South Africa as a "foreign policy president". However, this downplays his mastery of international affairs that resulted in the dynamism and substance that characterised South Africa's foreign policy during his administration (Moore, 2014).

While the pursuit of a world where Africa has a central place at the table may identify Mbeki as a transformational president at the outset of his first term, his hands-on approach in pursuit of his vision also casts him as a transactional president.

(Masters, 2017: 8)

Mbeki used his international stature to gain the backing of important states on the continent such as Nigeria, Senegal, and Algeria in pursuit of his African 
Renaissance. He took advantage of the opportunity presented by the inaugural summit of the AU in South Africa in 2002 to stress that Africa is a serious continent, arguing that it has a duty to "proclaim to the world that it is a continent of democracy, a continent of democratic institutions and culture - indeed a continent of good governance where the people participate and the rule of law is upheld" (Khadiagala and Nganje, 2016: 1568). Mbeki's African Renaissance efforts were evident in the OAU's transition to the AU and the establishment of NEPAD, peacemaking, and multilateral foreign policy.

Olivier's (2003: 815) description of Mbeki's attributes is so apt that it is worthy of extensive quotation:

Although Mbeki's philosophical approach to international relations is generally liberal and universal, he defines his primary goals mainly in terms of the ideology of his neo-pan-Africanism and the aspirations of developing countries in the southern hemisphere, with issues such as poverty, debt relief, racism and underdevelopment high on his foreign policy agenda. All the main strands of his foreign policy join together in his grand vision for Africa. He introduced and popularized the idealistic notion of an "African renaissance"; he is the seminal thinker behind, and principal author and articulator of, the New Partnership for Africa's Development (NEPAD), the foremost African peacemaker and multilateralist, a founding father and first chairman of the new African Union (replacing the anachronistic Organization of African Unity), a main player and outgoing chairman of the NonAligned Movement, Africa's strongest voice in the globalization debate between the rich North and the poor South, and the super-diplomat who has succeeded in placing Africa high on the global agenda.

Cognisant of his international clout, in pursuit of Pretoria's foreign policy of peacemaking, Mbeki embarked on shuttle diplomacy in states such as the DRC, Burundi, Sudan, Comoros, Côte d'Ivoire, and Liberia (Masters, 2017). His charisma also explains why international organisations such as the AU often deployed him as a peace envoy in conflict areas such as Côte d'Ivoire in 2004 and places such as the DRC, Rwanda, Zimbabwe, Eswatini, and Sudan in 2005 (Tella, 2020). South Africa continued to actively champion human rights, promote democracy, and engage in peacemaking during Mbeki's administration.

South Africa's transition experience has also garnered impressive soft power. Sidiropoulos (2014) asserts that Pretoria's soft power is primarily derived from the post-apartheid political settlement and the liberal constitution. The political transition that resulted in the first democratic elections in 1994 was inclusive as political parties across social and racial lines participated in the historic moment and it was crafted internally rather than by external actors (Sidiropoulos, 2014). Major actors in South Africa's transition including Desmond Tutu, Pius Langa, and Richard Goldstone promoted the country's experience across the globe. Tutu advanced the TRC model in tens of states; Goldstone offered his experience as a prosecutor to the international tribunals for Rwanda and Yugoslavia; 
and Langa played an important role in constitutional review commissions in Rwanda, Tanzania, Zimbabwe, and Sri Lanka (van der Westhuizen, 2016). The TRC was established to reveal the truth and address past injustices with the ultimate objective of putting the state on the path of reconciliation (Sidiropoulos, 2014). Chiroro's (2012: 2) observation is also worthy of extensive quotation:

Therefore, optimising national wealth and influence could enable South Africa as a nation, despite its antecedent economic and ideological contradictions and violent and oppressive past, to maximise its soft-power attributes to impose some specific outcomes on targeted actors in the international arena. South Africa has the soft power attributes to avoid the use of coercion by taking cognisance of its racial past; the richness of its diverse culture; the contradictions in socio-economic development; the fight against poverty and inequalities; and adherence to constitutionalism and the rule of law in setting the agenda and ensuring that the multilateral system can implement policies that are people-centred.

Gender equality in politics is another of the ideals that South Africa has been associated with. Pretoria has been a champion of the international women, peace, and security agenda which finds its legal basis in UN Security Council Resolution 1325 and other similar resolutions, and has promoted women's participation in conflict mediation, and the UN and AU's peacekeeping efforts (Cold-Ravnkilde, 2019). The state also contributed to SADG, the AU, and the UN's gender protocols. Pretoria's strong advocacy for women's rights and gender equality is reflected in its domestic politics. Women account for 42 per cent of the executive arm, 44 per cent of the legislature, 38.2 per cent of local government representatives, and 39 per cent of senior management positions in the civil service (Cold-Ravnkilde, 2019). In a 2018 survey, South Africa ranked tenth among the countries with the most women in parliament (World Economic Forum, 2019). Pretoria is thus well placed to champion the cause of women in the international arena despite the high levels of gender-based violence in the country. Indeed, South Africa has striven to promote this ideal in the international arena. For example, after the election of a South African woman, Nkosazana Dlamini-Zuma, as the AU Commission chairperson in 2012, Jacob Zuma then President of South Africa noted that:

the appointment of Dr Dlamini Zuma will build on the work of her predecessors, including Dr Jean Ping, and ensure a more efficient and effective AU Commission, particularly on the implementation of decisions pertaining to unity, peace stability, development and the upliftment of women and children.

(Chiroro, 2012: 6)

It is thus clear that South Africa seeks to ensure that women participate actively in Africa's political and socio-economic development. 


\section{Ubuntu, multilateral foreign policy, peacemaking-peacekeeping, and norm entrepreneurship}

\section{Ubuntu}

South African culture is arguably embedded in the philosophy of Ubuntu that stresses values such as harmony, caring, dignity, forgiveness, reciprocity, equality, and community. While many of these values are attributable to many African states, South Africa has gone a step further by ingraining them in its domestic and foreign policies. The TRC that attracted global admiration was embedded in Ubuntu principles, seen in granting amnesty to perpetrators of human rights abuses during apartheid. Qobo and Nyathi (2016) assert that while the significance of Ubuntu in an international system characterised by real politik is not obvious, in light of the challenges that confront this system, it seems critical. In view of globalisation and uncertainties that engender fear, mistrust, and humiliation, and put the weak at the mercy of the powerful, Ubuntu offers a paradigm that promotes common interests as opposed to the realist standpoint that underscores power and national interests (Qobo and Nyathi, 2016). Post-apartheid South Africa has often embraced multilateralism versus unilateralism in its engagement with other states in the international arena and has pursued a fair and just global order. This foreign policy posture underlines the philosophy of Ubuntu. The 2011 White Paper on South African foreign policy titled "Building a better world: The diplomacy of Ubuntu" highlights this quest. The preamble to the White Paper states that:

South Africa is a multifaceted, multicultural and multiracial country that embraces the concept of Ubuntu as a way of defining who we are and how we relate to others. The philosophy of Ubuntu means "humanity" and is reflected in the idea that we affirm our humanity when we affirm the humanity of others. It has played a major role in the forging of a South African national consciousness and in the process of its democratic transformation and nation-building.

(South African Government, 2011: 4)

The White Paper adds that "South Africa's unique approach to global issues has found expression in the concept of Ubuntu. These concepts inform our particular approach to diplomacy and shape our vision of a better world for all" (4) and highlights "common humanity, collaboration, cooperation, and building partnership over conflict" (4). Ubuntu presents an emancipatory philosophy that stresses non-racialism, non-sexism, democracy, and human dignity, essential values for a post-apartheid South Africa (Qobo and Nyathi, 2016). However, as le Pere rightly notes, this philosophy has not significantly shaped South Africa's foreign policy due to the Department of International Relations and Cooperation's (DIRCO) weak capacity, and the domestic challenges that confront the African National Congress (ANC)-led government (le Pere, 2017). In other 


\section{South Africa}

words, there is a gap between rhetoric and international behaviour and a disconnect between domestic and foreign policy (Qobo and Nyathi, 2016).

Nevertheless, beyond its relevance to African cultural systems, Ubuntu serves as an ideology that challenges the dominance of the West in the polarity of contemporary international politics in the areas of culture, knowledge, finance (Qobo and Nyathi, 2016), and influence. South Africa's quest to reform global governance that finds practical expression in its membership of BRICS and its bid to become a permanent member in a reformed UN Security Council fit this context. Ubuntu underlines common humanity and responsibility to one another, values that are increasingly important in the contemporary global order where there seems to be a moral vacuum. In another display of Ubuntu, South Africa invited other African states to participate in the BRICS summits the former hosted in 2013 and 2018, which led to the mooting of the idea of BRICS Plus, the BRICS and other African states (Madise and Isike, 2020). Beyond its relevance to South Africa's multilateral relations especially with regard to economic and security matters, Ubuntu would add more value if it were to make inroads in the socio-economic development of South Africans (Qobo and Nyathi, 2016). This prompted Nussbaum (2003: 2) to reflect:

I am convinced that ubuntu could enrich the range of new paradigms emerging worldwide that are currently inspiring business, political and civic leaders to transform organizations. Finally the spirit of ubuntu, if taken seriously, could influence and change relationships between nations.

\section{Peace diplomacy and democracy promotion}

An important contributor to South Africa's soft power is its peacemaking and peacekeeping in places like Burundi, the Central African Republic (CAR), Comoros, the DRC, Ethiopia/Eritrea, Guinea-Bissau, Côte d'Ivoire, Lesotho, Liberia, Madagascar, Mali, Rwanda, São Tomé and Príncipe, Somalia, Sudan, South Sudan, and Zimbabwe (Tella, 2017). South Africa is unmistakably a regional peacemaker on the continent. Exercising its belief in democratic peace, Pretoria has sought to promote democracy and guarantee peace in states such as Angola, the Comoros, the DRC, Lesotho, Nigeria, Sudan, and Eswatini through mediating between the conflicting parties, resulting in coalition governments as in Zimbabwe and Botswana, conflict resolution in Lesotho, and "quiet diplomacy" in Nigeria (Landsberg, 2000). South Africa's democracy promotion and peacemaking in many of these states seem inseparable as peacemaking often dovetails with democracy promotion.

Mabera (2018) states that South Africa's peace missions can be understood from four dimensions: political, economic, security, and normative. The political imperative highlights South Africa's role as a major peacemaker and its quintessential soft power on the continent; the economic standpoint illustrates the nexus between peacekeeping and South Africa's economic interests as evident in the missions in the DRC and South Sudan; the security perspective demonstrates the threat to South Africa's national security arising from the security challenges on 
the continent such as ethnic conflict, terrorism, piracy, and transnational organised crime; and the normative context projects South Africa's role as a norm entrepreneur seen in its promotion of values such as multilateralism and panAfricanism (Mabera, 2018). Pretoria's role in the establishment of the African Peace and Security Architecture (APSA), the main institutional framework for peacemaking, peacekeeping, and peacebuilding on the continent, is testimony to South Africa's image as a major peacemaker in Africa. However, the country is often accused of infusing a beggar thy neighbour policy in its peace diplomacy by promoting the interests of its multinational companies. Detractors cite South Africa's obstruction of the construction of a vehicle assembly plant and a cement factory in Botswana and Namibia, respectively, as examples.

In 1996, Thabo Mbeki played a crucial role in peacemaking in the DRG following the Banyamalengu rebellion that led to the ousting of Mobutu Sese Seko. In negotiating between Mobutu and rebel leader Laurent Kabila, Pretoria deployed smart power (a combination of soft and hard power) by providing military support to some Central African states (hard power) and brokering peace deals and providing assistance for post-conflict reconstruction (soft power) (Landsberg, 2000) leading to the emergence of Kabila as the President of the DRC in 1997. However, this did not halt the conflict, nor did the Lusaka Ceasefire Agreement in 1999 between the DRG and five key states, Angola, Rwanda, Uganda, Namibia, and Zimbabwe. It was only after the killing of Laurent Kabila and the emergence of his son Joseph Kabila as President that there were hopes for peace. Nonetheless, the situation deteriorated to the extent that the mandate of the UN Organisation Mission in the Democratic Republic of the Congo (MONUC) was expanded under Security Council Resolution 1856 in 2007 (renamed the UN Organisation Stabilisation Mission in the Democratic Republic of Congo (MONUSCO) in 2010) (Prinsloo, 2019).

In a similar vein, South Africa's intervention in the conflict in Burundi from 1999 resulted in a peace agreement among the belligerents and the eventual UN peace mission that culminated in the election that led to the emergence of Pierre Nkurunziza as President in 2005 (Khadiagala and Nganje, 2016). This conflict emerged as a result of tension between rebels that resulted in a humanitarian crisis with the attendant refugee problem. The Mandela-led rounds of negotiations eventually resulted in the Arusha Peace and Reconstruction Agreement that was signed in the year 2000, which proposed a transitional government that was boycotted and contested by some rebels, further escalating the conflict (Prinsloo, 2019). Continued conflict led to the deployment of South African troops under the auspices of UN Security Council Resolution 1375, which provided the legal cover for Pretoria to deploy 754 troops in 2001. This was followed by the establishment of the AU Mission in Burundi (AMIB) in April 2003. The mission drew its troops from South Africa, Ethiopia, and Mozambique and was renamed the South Africa-led UN Operation in Burundi (ONUB) in 2004. It withdrew in 2016 leaving South African troops behind for another three years before they eventually returned home, paving the way for the relatively peaceful 2010 presidential elections (Prinsloo, 2019). These are some of the few instances that 


\section{South Africa}

Pretoria has been able to successfully promote democracy in Africa in line with its foreign policy objectives.

Following the ousting of the democratically elected President Marc Ravalomanana by Andry Rajoelina in Madagascar in 2009, South Africa provided leadership in SADC to resolve the crisis. After Rajoelina's coup, SADC and the AU swiftly suspended Madagascar. SADC subsequently proposed a transitional government to oversee democratic elections, and in 2012 President Zuma mediated between Ravalomanana and Rajoelina. This resulted in the 2013 elections and the emergence of Hery Rajaonarimampianina as president (Khadiagala and Nganje, 2016). Given South Africa's struggle with democracy promotion in places like Zimbabwe and Eswatini, it scored valuable diplomatic points with regard to Madagascar. It is clear that Pretoria's peacemaking in these states dovetailed with democracy promotion redounding to the double soft power benefits.

\section{Multilateral foreign policy}

In his popular 1993 article published in Foreign Affairs, Nelson Mandela highlighted the guiding principles of South Africa's foreign policy:

- Human rights are central to international relations and they extend beyond the political, embracing the economic, social, and environmental;

- Just and lasting solutions to the problems of humankind can only come about through the promotion of democracy worldwide;

- Considerations of justice and respect for international law should guide the relations between nations;

- Peace is the goal for which all nations should strive, and where this breaks down, internationally agreed and nonviolent mechanisms, including effective arms-control regimes, must be employed;

- The concerns and interests of the continent of Africa should be reflected in our foreign-policy choices;

- Economic development depends on growing regional and international economic cooperation in an interdependent world.

These convictions stand in stark contrast to how, for nearly five decades, apartheid South Africa disastrously conducted its international relations (Mandela, 1993: 87).

As far back as 1993, Mandela recognised that the world was a dangerous place and therefore urged states to remain committed to human rights, and unambiguously noted that "consequently, South Africa will not be indifferent to the rights of others. Human rights will be the light that guides our foreign affairs" (Mandela, 1993: 88). He further highlighted the centrality of democracy in the guarantee of human rights (Mandela, 1993).

South Africa's foreign policy in the immediate post-apartheid period was guided by the principles set out in Mandela's article. In the first four years of 
democracy, the Mandela administration intervened in states such as Angola, Lesotho, Zaire (now the DRC), Israel-Palestine, Northern Ireland, East Timor, Sudan, UK-Libya, and US-Iraq to resolve issues ranging from constitutional crisis, to conflict mediation, brokering peace deals, refugee crises, terrorism, and nuclear disarmament (van der Westhuizen, 2016).

By the year 2000, South Africa was a signatory to 70 multilateral treaties and had joined over 40 intergovernmental organisations (van der Westhuizen, 2016). Pretoria is the continent's sole member of BRICS, IBSA, and the G20. It has actively participated in diverse multilateral platforms including the 1995 extension of the Nuclear Non-Proliferation Treaty, the 1997 Ottawa Process on the banning of land mines, and the 1998 adoption of the Rome Statute that led to the establishment of the International Criminal Court (ICG); and has hosted important international conferences including the 2000 UN AIDS conference, the 2001 UN World Conference against Racism, Xenophobia and Related Discrimination, the 2002 UN World Summit on Sustainable Development, the 2002 inaugural summit of the AU, the 2011 UN Climate Change Conference, and the 2013 (Tella, 2017) and 2018 BRICS summits.

Having shrugged off its status as a pariah state following the end of apartheid, South Africa joined many sub-regional, regional, and global organisations including SADC, the OAU (now the AU), and the UN, all in 1994, to further pursue its foreign policy objectives of democracy and human rights promotion, and peacemaking, and ultimately to "right the wrongs" of apartheid such as the destabilisation of Frontline States like Zambia, Zimbabwe, Angola, Tanzania, and Lesotho (Akokpari, 2018). In SADC, Pretoria has exercised its soft power by providing the leadership expected of a hegemon in the sub-region. Given that South Africa accounts for more than 60 per cent of Southern Africa's economy and that the sub-region is its primary market in Africa, Pretoria's economic diplomacy is critical in SADC. South Africa has mainly exhibited its role as a major peacemaker in Africa in the SADC sub-region, providing leadership for a tripartite force alongside Botswana and Zimbabwe to quell protests against Prime Minister Pakalitha Mosisili's government in 1998 in Lesotho, and SADC's role in resolving the political deadlock in the same country in 2015 (Akokpari, 2018). Similarly, South Africa led SADC's efforts to resolve the political crisis in Zimbabwe between the Robert Mugabe-led Zimbabwe African National Union Patriotic Front (ZANU-PF) and the Morgan Tsvangirai-led Movement for Democratic Change (MDC), which resulted in the 2008 Global Political Agreement (GPA) and the subsequent 2009 Government of National Unity.

It was the turn of the DRG between 2002 and 2004, and Madagascar in 2009 (Akokpari, 2018). Pretoria also played a prominent role in South Sudan's independence in 2011 (Akokpari, 2018). It has played a leading role towards reform of SADC including drafting and implementation of protocols ranging from free trade to security, and politics (Landsberg, 2012). In certain instances, South Africa's leadership in Southern Africa has been constrained by resistance from some states such as Angola and Laurent Kabila's DRC, and Pretoria has been reluctant to act in other cases. An example is its "quiet diplomacy" in Robert 
Mugabe's Zimbabwe in the face of human rights abuses (Alden and Le Pere, 2009).

South Africa's contribution to the AU can be subsumed within the idea of the African Renaissance, which contributed to Pretoria's zeal to transform the OAU to the AU in 2002. The African Renaissance rests on four key principles: AUcentred continental integration; democracy and good governance; economic development galvanised by NEPAD; and peacemaking (Khadiagala and Nganje, 2016). South Africa led the AU Mission in Burundi (AMIB) in 2003 and was also active in conflict areas like Côte d'Ivoire and the CAR.

NEPAD identifies five key pillars that have the potential to foster Africa's development:

1 Democracy, good governance, peace and security;

2 Responsible economic and corporate governance;

3 Infrastructure and information technology;

4 Human resource development (notably health and education);

5 Agriculture and market access.

(Landsberg, 2012: 443)

South Africa led the efforts to outline NEPAD's six key development programmes including science and technology, industrialisation, agriculture, environment, transport, and regional economic integration (Landsberg, 2012). Pretoria's development initiative, the Millennium Partnership for African Recovery (MAP) designed by Mbeki's administration to address African debt, alongside two other documents - former Senegal President Abdoulaye Wade's OMEGA plan and the Economic Commission for Africa's (ECA) Global Compact for Africa Recovery, resulted in NEPAD and the APRM (Akokpari, 2018). Similarly, South Africa played a leading role in the drafting of the APRM's base documents and other key instruments. South Africa is of the firm view that the APRM should establish a link between governance, democracy, peace and security, and development and that all member states should adopt and comply with the APRM's provisions. Pretoria is thus a norm entrepreneur.

South Africa has served three terms on the UN Security Council: 2007-2008, 2011-2012, and 2019-2020. During its first stint, South Africa was involved in conflict resolution in states such as the DRG, Burundi, Côte d'Ivoire, Sudan, and Zimbabwe and endeavoured to strengthen African organisations including the $\mathrm{AU}$ and SADC and advocated for security sector reform. In its second term (2011-2012), South Africa pushed for strengthened cooperation between the UN Security Council and the AU Peace and Security Council resulting in annual meetings between the two on African security (Tella, 2019). Given that the permanent members of the UN Security Council do not reflect the realities of the structure of power in contemporary international relations, Pretoria advocated for permanent members of the Security Council to include states such as South Africa, Nigeria, India, Germany, Brazil, and Japan, as opposed to the current structure that has five members - the United States, China, Russia, Britain, and 
France. In 2019, during its last term, South Africa argued for the need to be cautious and await the official result of the DRC's presidential elections as it was an internal issue that could be resolved by the Central African state. This was contrary to France and Belgium's position, and Pretoria's stance partly contributed to Félix Tshisekedi's emergence as the country's president (Tella, 2019). Similarly, Pretoria reiterated non-interference in the domestic affairs of Burundi and Venezuela following the internal security and US-led "regime change" agenda respectively, in these states.

Despite the obvious challenges that confront South Africa in its engagement with Africa - including a weak domestic base exemplified by its economic decline, a gap between Pretoria's power resources and actual influence, and weak influence on authoritarian regimes such as Mugabe's Zimbabwe and Eswatini Pretoria still commands respect in the international arena, seen in its "symbolic representivity" of Africa in organisations such as BRICS, the G20, and the UN Security Council (Alden and Schoeman, 2015). In other words, South Africa's leadership on the continent is derived from external actors' need to have an African representative in the international arena (Alden and Schoeman, 2015). South Africa is by far the most dominant player in its sub-regional organisations including SADC and the Southern African Customs Union (SACU), and is one of the most significant players in continental organisations including the AU, NEPAD, and the APRM. These activities reinforce South Africa's growing international status as a soft and emerging power in the international arena.

Nuclear diplomacy is an important area that South Africa has tapped from its soft power reservoir to demonstrate global leadership. Voluntarily relinquishing its nuclear arsenal bolstered Pretoria's norm entrepreneurship, which has redounded into soft power benefits, evident in its leading role in international regimes on nuclear armament. While nuclear armament was dismantled by the apartheid regime on the eve of black majority rule in 1994, it jelled with the postapartheid administration's resolve to embrace peaceful resolution of disputes, multilateralism, and democratic norms as opposed to the arrogant, unilateral, aggressive, and obnoxious international behaviour of the apartheid regime which culminated in the destabilisation of contiguous states. It is against this backdrop that Pretoria is an important player in international regimes on peaceful use of nuclear weapons as it is well placed to offer its experience and moral authority to act as the voice of Non-Nuclear Weapons States (NNWS) and the Non-Aligned Movement (NAM) in negotiations for Multilateral Nuclear Approaches (MNAs) (Ogunnubi, 2020). Pretoria's experience could well serve as a model for nuclear weapons states should they wish to relinquish their nuclear capacity and offers lessons on the dispensability of nuclear warheads to potential nuclear-weapon states (NWS). For example, South Africa's disarmament partly dissuaded its contemporaries on the continent such as Nigeria, Egypt, and Libya from acquiring a nuclear arsenal (Ogunnubi, 2020).

South Africa also played a critical role in the 2000 Nuclear Non-Proliferation Treaty Review Conference and the extension of the Non-Proliferation Treaty in 1995 (Ogunnubi, 2020). At the level of rhetoric, Pretoria has continued to 
challenge the dominance and double standards of NWS who are reluctant to destroy their nuclear warheads, but want to prevent the proliferation of nuclear capability among NNWS. Beyond being a signatory to the Non-Proliferation Treaty, South Africa has shown its commitment to nuclear disarmament and peaceful use of nuclear energy through its role in the African Nuclear Weapons Free Zone Treaty (ANWFZ), the African Uranium Alliance, the Humanitarian Initiative, and the New Agenda Coalition (NAG) (Ogunnubi, 2020). South Africa prides itself on being the only state to have voluntarily relinquished its nuclear arsenal. This instantly bolstered Pretoria's soft power, illustrated by South Africa's leading role in global nuclear disarmament, especially its election to the standing UN Conference on Disarmament (Tella, 2017). Pretoria has been called upon to offer its nuclear disarmament experience in states such as Iraq. Van Wyk (2014: 202) captures South Africa's influence in Iraq thus:

Once the South African delegation left Iraq, it became known that the Iraqi government had commenced with the dismantling and destruction of its missiles, an issue in respect of which the South African delegation "had tried to persuade the Iraqis". Thus, the South African delegation succeeded in at least one instance. South Africa was able to focus on a particular issue - disarming Iraq - by selecting a particular diplomatic approach.

Indeed, the then US Secretary of State, Colin Powell, suggested that South Africa's experience could well serve as a model for Iraq before the US invasion in 2003 (van der Westhuizen, 2016). South Africa has continued to advance a nuclear warhead-free international system and has been vocal in its call for the right to peaceful use of nuclear energy as is evident in its policy on Iran's nuclear capacity, with Pretoria calling for peaceful negotiation rather than sanctions imposed by the West and emphasising Iran's right to peaceful use of such energy (Tella, 2017). Accordingly, South Africa enjoys the status of a norm entrepreneur in the area of nuclear armament and disarmament in the international system.

In terms of environmental politics, South Africa has played a significant role in international negotiations on climate change and has made several commitments to reduce carbon emissions, including very ambitious ones such as those in the 2009 UNFGCG conference in Copenhagen in which the country pledged to significantly reduce its greenhouse gas emissions by 34 per cent by 2020 and 42 per cent by 2025 (Chiroro, 2012). While these goals do not seem to be achievable within the set date, what is germane is the fact that South Africa has shown its willingness to sacrifice its short-term interests for the longterm benefit of the world. In 2011, South Africa hosted COP 17 in Durban that led to the Durban Platform for Enhanced Action, which initiated a new round of negotiations targeted to be concluded and operationalised by 2015 and 2020 (Chiroro, 2012).

More specifically, Pretoria's norm entrepreneurship has been reflected in the following: the international treaty to ban landmines; the 1995 extension of the treaty on the Non-Proliferation of Nuclear Weapons; the 1996 formulation of 
the Pelindaba Treaty on a nuclear weapon-free Africa; and outlawing child soldiers (Ogunnubi and Okeke-Uzodike, 2015).

\section{Civil society organisations and multinational corporations}

Nye (2004) notes that soft power is mainly derived from civil society rather than the state. South Africa can lay claim to a robust civil society that has enhanced its soft power profile in the international arena. Civil society organisations (CSOs) that take up different international issues such as human rights, democracy, minority rights, and protection of the environment are crucial to the sustenance of South Africa's soft power. It is against this backdrop that Sidiropoulos (2014: 199) argues that "many (South African) civil society actors, building on their experience in the transition to democracy, have taken part in diplomatic initiatives in Africa". Examples include the role of the Congress of South African Trade Unions (COSATU) in sensitising the international audience to human rights abuses in Eswatini; the Southern African Litigation Centre's (SALC) promotion of human rights and the rule of law in Southern Africa; and the African Centre for the Constructive Resolution of Disputes' (ACCORD) promotion of peace and conflict resolution across Africa (Ogunnubi and Tella, 2017). Many South African CSOs have been involved in monitoring elections and thereby promoting democracy in states such as the DRG and Zimbabwe and strengthening diplomatic relations between South Africa and China (April, 2009). Civil society actors have been vocal in critical issues such as the Nkandla saga, the Dalai Lama debacle, the 2011 Libyan conflict, and the situation in Zimbabwe during and post Robert Mugabe's administration (Ogunnubi and Tella, 2017). In recognition of the role of the civil society actors, DIRCO invited various CSOs to a workshop to review the country's foreign policy in Pretoria in October 2019.

There is no gainsaying that MNGs are one of the most important non-state actors in today's world. This is reflected in the resources they have at their disposal. While the economic strength of the largest African MNGs lags far behind the most powerful global ones such as Apple, China Mobile, Toyota, and BP plc (formerly British Petroleum), the influence of African companies like MTN and the Dangote Group cannot be ignored. South African companies have established their footprint across Africa and have accrued remarkable economic gains.

More than 120 South African companies have established a foothold in Nigeria alone, while Tanzania is home to 228 (IOL, 2019). These range from banks such as Standard Bank, Nedbank, the Absa Group, and First National Bank (FNB); to retailers including Mr Price, Shoprite, and Woolworths; and service organisations such as Multichoice (DStv), South African Airways (SAA), and MTN. However, South African MNCs have been accused of practicing a beggarthy-neighbour policy in the region. Detractors often highlight Botswana's car assembly plant and Namibia's cement industry. Some South African firms, especially MTN, have also been involved in controversies. These include MTN's disregard for the Nigerian government's directive to disconnect unregistered subscribers, which culminated in: Nigeria imposing a $\$ 5.2$ billion fine on the 
company; its cordial relationship with authoritarian regimes including Paul Kagame of Rwanda and King Mswati III of Eswatini; and the licence bribery scandal in Iran. In addition, many South African companies have been accused of exporting apartheid-era racism reflected in the working conditions of locals in the host countries and the establishment of exclusive schools and clubs in places like Tanzania (Tella, 2018b). These realities undermine the liberal ideas that these companies ostensibly promote across Africa. It is thus no surprise that there have been protests against South African companies and that indigenisation policies have been adopted in states such as Tanzania and Zimbabwe (Ogunnubi and Tella, 2017). Nonetheless, these companies are fundamental in the promotion of South Africa's soft power. The data from Brand South Africa below reveals the dominance of South African (alongside Nigerian) companies in terms of most admirable companies in Africa. As noted earlier, through its soap operas, Multichoice (DStv) has made inroads in challenging African tradition that celebrates patriarchy and homophobia. For its part, MTN has transformed the telecommunications sector in Africa. Hardy (2015) captures the soft power capacity of some of these MNGs:

M-Net and DStv certainly know how to move with the times. They have conveniently tapped into, and benefit from, South Africa's new-found hegemony on the continent. They are as much a part of what's represented by that Nando's burger you eat in Dakar, that Vodacom cellphone contract in Lagos, or the Shoprite you visit in a gated community in Dar-es-Salam or Maputo. In effect, they are part and parcel of South African soft power.

Beyond the entertainment and national pride that these companies provide, they are instrumental to South Africa's economic strength on the continent; MNGs'

Table 4.5 Top ten most admired African brands in 2020

\begin{tabular}{clll}
\hline Rank & Brand & Industry group & Country of domicile \\
\hline 1 & Dangote & Consumer, & Nigeria \\
& & Non-Cyclical & \\
2 & MTN & Telecom Provider & South Africa \\
3 & DStv & Media & South Africa \\
4 & Anbessa & Apparel & Ethiopia \\
5 & Azam & Consumer, & Tanzania \\
& & Non-Cyclical & \\
6 & Glo & Telecom Provider & Nigeria \\
7 & Ethiopian Airlines & Aviation & Ethiopia \\
8 & Vodacom & Telecom Provider & South Africa \\
9 & Shoprite & Retail & South Africa \\
10 & Innoson & Auto Manufacturers & Nigeria \\
\hline
\end{tabular}

Source: author's adaptation from Brand Africa, 2020. 
tentacles on the continent are crucial for South Africa's economic interests and hegemonic posture in Africa.

Table 4.5 lists the top ten most admired African brands. It is clear that South Africa and Nigeria dominate the list. The full list, which has 25 brands, includes seven South African, six Nigerian, five Kenyan, and two Ethiopian companies. Togo, Tanzania, Uganda, Zambia, and Zimbabwe each have one company on this list. The top 100 most admired brands in Africa feature only three African countries with six Nigerian companies, five South African firms, and one Kenyan company (Brand Africa, 2020). South African companies that range from telecommunications to media and retail are critical in projecting the country's soft power. Beyond their value in terms of promoting the economic interests of their home country, the telecommunications companies provide an avenue for people in their host countries to be able to communicate with others far and wide. The media serves as a veritable platform for South Africa's cultural exports. It is thanks to DStv that other African states are able to view South African entertainment, especially soap operas, music, and other cultural outputs, while the retail companies have introduced other African states to South African groceries. This all redounds to South Africa's soft power in the realms of economic and cultural diplomacy.

South African companies have invested in diverse industries across Africa ranging from telecommunications, to financial services, mining, manufacturing, construction, and leisure (Alden and Le Pere, 2009). The country's MNGs, such as MTN, Vodacom, DStv (Multichoice), Standard Bank, Absa Group Limited, the Protea Hotel Group, Shoprite, Woolworths, and Mr Price, have become ubiquitous in African markets. The significance of these firms to South Africa's economy dictates that the South African government has been involved in generating deals and ensuring an enabling environment for these companies in their host countries. For example, Pretoria's peacemaking partly contributed to the treaty between South Africa and the DRG in 2013 that commits South Africa to obtain 2,500 megawatts worth of energy from the Inga Dam project on the Congo River (Turpin, 2019). This will clearly benefit Eskom (South African electricity public utility) not only in generating electricity for local consumption but potentially also further afield, particularly in some parts of North Africa, and in West Africa (Alden and le Pere, 2009) that suffers from chronic shortages. A more recent example was then President Zuma's shuttle diplomacy to Nigeria in 2016 following the dispute between the Nigerian government and MTN that resulted in the former imposing a fine of $\$ 5.2$ billion due to the latter's disregard for the government's directive to disconnect unregistered subscribers. In view of the growing tension and the fact that MTN has more than 61.5 million subscribers (MTN, 2019) - more than the population of South Africa - in Nigeria, this shuttle diplomacy to resolve the crisis, among other issues, was a smart move.

\section{Challenges to South Africa's soft power}

Despite its record of impressive soft power, enormous challenges constrain South Africa in effectively exercising this power. This stems from its domestic 
circumstances including the triple challenge of poverty, unemployment, and inequality that have frustrated South Africa's foreign policy objectives. This is principally as a result of the fact that resources required to exercise its role as a regional power are diverted to domestic needs (Schoeman, 2015). This has been complicated by increasingly weak investor confidence, a weak Rand, and a consistently low growth rate. Other challenges include political brouhaha, double standards on human rights, and xenophobia.

\section{Economic constraints: poverty, inequality, and unemployment}

South Africa has the reputation of being one of the most unequal states in the world. Inequality particularly manifests along racial lines. Schoeman (2015) notes that from 1996 to 2012, the ratio of white per capita income to that of other races increased from 3.9:1 to 4.5:1. This implies that despite more than two-anda-half decades of majority rule, a large proportion of the black majority remains poor and is over-reliant on social grants, with more than 17 million (more than 30 per cent of the population) beneficiaries. The World Bank (2018: 23) notes that "South Africa remains trapped in the cycle of high inequality and slow job creation ... inequalities remain extremely high despite effective redistributive policies". However, the effectiveness of these policies including those on affirmative action and black economic empowerment remains doubtful in light of the plight of the majority of the black population. Unemployment in the last quarter of 2019 stood at 29.1 per cent (The Brenthurst Foundation, 2020). Against this background, South Africa is significantly constrained in deploying resources to achieve its foreign policy objectives in Africa and beyond as a large portion of its wealth is channelled to tackling domestic imperatives. This clearly has an enormous impact on its soft power. For instance, as noted earlier, South Africa's soft power has been enriched through its peacemaking, peacebuilding, and aid in Africa. However, there have been significant cuts in South Africa's peacemaking role in the post-Mbeki era.

The Zuma administration clearly prioritised its rapport with the BRIC countries to the detriment of pursuing South Africa's foreign policy objectives in Africa (Sidiropoulos, 2014), evident in declining funding to DIRCO and the South African National Defence Force (SANDF). For example, South Africa spent 1.1 per cent of its GDP on military expenditure between 2007 and 2016 (Mabera, 2018). Smaller states in the Southern African sub-region, including Angola, Zimbabwe, Botswana, and Namibia, spent more than two per cent in 2016 (Mabera, 2018). Pretoria is also not one of the major contributors to the UN's peacemaking efforts. Addressing parliament in 2016, then Minister of DIRCO, Maite Nkoana-Mashabane, signalled that South Africa would have to close some of its missions abroad as the department's budget in the 2016/2017 financial year was cut by R153 million and would be further reduced by R1.8 billion in years to come (Nkoana-Mashabane, 2016). This implies that, in the face of domestic imperatives, South Africa is increasingly struggling to effectively pursue its foreign policy objectives. It is thus no surprise that Pretoria has 
struggled to meet its financial commitments to regional organisations in Africa, particularly the SACU and SADC, prompting states such as Eswatini to seek IMF and World Bank loans (Tella, 2018b). This has significantly impacted on the status South Africa built over the years as a significant aid donor and a major peacemaker on the continent and challenges its claim to regional hegemony as states within its primary sphere of influence continue to seek external assistance in the face of South Africa's domestic circumstances. Indeed, many citizens are critical of South Africa's involvement and contributions to sub-regional and regional organisations and groupings like BRICS (Chiroro, 2012).

Domestic realities in South Africa have led to violent protests in the country, reinforcing its image as a violent state. Indeed, protests (violent and non-violent) have become an integral part of South Africa's body politic to the extent that it has been dubbed "the protest capital of the world". The 2012 Marikana massacre, which claimed the lives of 34 people with 78 injuries, symbolises the violent character of post-apartheid South Africa. The country does not fare well in various indices that measure peace and the level of state violence. Table 4.6 shows how South Africa currently fares.

South Africa ranks 123rd out of the 163 countries included in the survey. While states such as Mauritius, Botswana, Ghana, Zambia, Liberia, and Malawi feature in the top ten most peaceful African states, South Africa is ranked 32nd. This has punctured South Africa's soft power such that some African states do not perceive Pretoria as having the moral authority to intervene in other states' conflicts. For example, following South Africa's comments on the levels of violence in Egypt, the Egyptian foreign ministry responded:

Rather than describing protests involving firearms and Molotov cocktails against security forces as well as road blocking and threats against vital installations as legitimate protests, the South African government should

Table 4.6 2020 Global Peace Index

\begin{tabular}{lcll}
\hline African rank & World rank & Country & Score \\
\hline 1 & 23 & Mauritius & 1.544 \\
2 & 33 & Botswana & 1.693 \\
3 & 43 & Ghana & 1.776 \\
4 & 44 & Zambia & 1.794 \\
5 & 46 & Sierra Leone & 1.82 \\
6 & 47 & Senegal & 1.824 \\
7 & 52 & Tanzania & 1.85 \\
8 & 53 & Namibia & 1.861 \\
9 & 57 & Liberia & 1.877 \\
10 & 59 & Malawi & 1.885 \\
32 & 123 & South Africa & 2.317 \\
\hline
\end{tabular}

Source: author's adaptation from Institute for Economics and Peace, 2020. 
concentrate on restoring the rights of its protesting miners against whom the most brutal force was used rather than interfering in the internal affairs of an African country of the size and standing of Egypt.

(Mada Masr, 2013: para. 8)

It is clear that South Africa's domestic situation has undermined its capacity to effectively exercise its soft power to pursue its foreign policy objectives.

Given the ongoing coronavirus pandemic (COVID-19), the South African Reserve Bank predicted that the country's GDP would contract by 6.1 per cent in 2020, and would grow by 2.2 per cent and 2.7 per cent in 2021, and 2022, respectively (South African Government, 2020). Focusing on three possible scenarios: (i) Quick (quick containment of the pandemic, and economy recovery), (ii) Slow (longer containment, and slower economic recovery), and (iii) Long (much longer containment, and much longer economic recovery), a 2020 report prepared by the Southern Africa - Towards Inclusive Economic Development (SA-TIED) programme suggests that the post-COVID-19 growth rate would be -3 per cent in the Quick scenario, -10 per cent in the Slow scenario, and -14 per cent in the Long scenario in 2020 (SA-TIED, 2020). However, the economy was in bad shape prior to the emergence of COVID-19, illustrated by the official unemployment rate of 29.1 per cent in the final quarter of 2019, and effective under- and unemployment that stood at 40 per cent, with the youth accounting for more than 50 per cent (The Brenthurst Foundation, 2020).

In his Freedom Day address on 27 April 2020, President Ramaphosa noted that COVID-19 had not only revealed deep levels of inequality, but also provided an opportunity to "re-imagine equality in South Africa". This is informed by the fact that while many skilled and semi-skilled workers continued to work (mostly remotely) in the lockdown period, many (if not most) unskilled workers were not paid their salaries, and in extreme cases lost their jobs. While inequality was a major challenge prior to COVID-19, the pandemic will further widen the gap between the rich and the poor. The most recent Poverty Trends report prepared by Statistics South Africa (Stats SA) in 2017 revealed that 55.5 per cent of South Africans fell below the Upper Bound Poverty Line (Stats SA, 2017). It is thus a herculean task to tackle poverty and inequality during and post-COVID-19.

\section{Political quagmire}

In line with successive post-apartheid administrations' preference for soft power in lieu of hard power, South Africa's parliament has climbed on the bandwagon to enhance the country's soft power profile. In 2008, South Africa chaired the Inter-Parliamentary Union's (IPU) 118th Assembly, tagged "Pushing back the frontiers of Poverty", and it has also played important roles in other multilateral frameworks such as the Commonwealth Parliamentary Association (CPA), PanAfrican Parliament (PAP), SADC Parliamentary Forum, and African, Caribbean, and Pacific Group of States-European Union Forum (ACP-EU) (Masters, 2015). The South African parliament's soft power stance is reflected in the 2006 Policy 
Perspectives and Operational Guidelines for Parliament's Engagement and Involvement in International Relations. The document emphasises engagement and communication with other countries' parliaments with the ultimate objective of promoting South Africa's culture, and enhancing Parliament's, and by extension the state's, international profile (Masters, 2015). However, the parliamentary brouhaha that occurred, particularly during the annual State of the Nation addresses by President Zuma between 2015 and 2017, significantly tarnished the image of the South African parliament (Tella, 2018b). The chaos resulted from opposition parties' (especially the Economic Freedom Fighters' [EFF]) demand for the President to inform parliament and the public how he would repay taxpayers' money spent on his private residence in Nkandla, KwaZulu-Natal.

A 2014 report by Public Protector Thuli Madonsela estimated the cost of the upgrades to the homestead at R246 million (Public Protector, 2014). The incidents that followed included Members of Parliaments' (MPs) disregard for parliamentary rules, Speaker Baleka Mbete's loss of control of parliament, logjams, walk-outs by opposition MPs, and security officials' forceful eviction of MPs. This drama was shown by many television channels, exposing the decay in South African politics to the outside world. When South Africa's parliament raised concerns regarding the state of democracy in Eswatini, Percy Simelane, spokesperson for Eswatini's government, remarked, "Had we not known better, we would be asking the South African electorate to correct the mistakes they made during the last election" (Mail \& Guardian, 2013a: para. 11). The parliamentary fracas between 2015 and 2017 further damaged parliament's credibility. Calland and Recht (2015: 315) argue that "the EFF's disruptions arguably weaken parliament's reputation as a space of dignity and order, one that hosts respectful proceedings and conducts serious business - and in principle this can have wide reaching negative effects on democracy itself".

In the past decade, corruption has littered South African politics. The highprofile cases of Nkandla, and Guptagate, and scandals associated with parastatals such as South African Airways (SAA), Eskom (the power utility), the Passenger Rail Agency of South Africa (PRASA), and the South Africa Social Security Agency (SASSA) led to public outrage. However, it was the Nkandla saga and Guptagate that mainly attracted international attention.

The Nkandla Report stated that R246 million in public funds had been used illegally to renovate then President Zuma's private residence. This scandal reveals the endemic nature of corruption in the country. Officially, the renovation was supposed to have been meant to upgrade the security fixtures of the residence. However, non-security features including an amphitheatre, a swimming pool, a chicken run, and a visitor's centre were built (Public Protector, 2014). Dominic Heil, the managing director of Reputation Institute South Africa, notes that a state's image is worth billions of dollars and critical to its tourism, trade, and investments inflows. He further states that:

We should actually not see Nkandla as a 200 million rand problem, it's a multi-billion rand problem for the country. [The president] would know 
that, and that makes it even worse. In any normal democracy, if you have this multi-institutional meltdown that we're seeing, there would be no question that this government would no longer be in place today.

(CNBC Africa, 2014: para. 9)

Guptagate is used in South Africa to describe an Indian family's (the Guptas) orchestrated state capture, which manifested in its enormous influence on cabinet appointments and on Jacob Zuma to promote its business interests in the country. The Gupta family - three brothers, Ajay, Atul, and Rajesh - migrated from India in the 1990s. As early as 2010, they were among a business delegation that accompanied Zuma on a state visit to India (February, 2019). Other delegates were noted to have complained about the Gupta brothers' overwhelming influence on Zuma's itinerary (February, 2019). Around the same period, various media outlets and COSATU began to scrutinise the relationship between the Guptas and the Zuma administration. The government debunked speculation of corruption with then ANG Secretary-General, Gwede Mantashe, going as far as describing the Guptas' critics as racist, noting that they were being targeted because of their Indian origins (February, 2019). As it turned out, the family became embroiled in a number of controversies including the landing of a plane carrying Gupta family's wedding guests at the Waterkloof Airforce Base in Pretoria, the removal of Minister of Finance Nhlanhla Nene, and the subsequent claim by his Deputy Mcebisi Jonas that the Guptas offered him his boss's position (which he rejected) in return for him to lay off some senior officials at Treasury, and the allegation by former ANC Member of Parliament Vytjie Mentor in 2016 that at a meeting at their residence in 2010, the Guptas offered her the Cabinet public enterprises portfolio in exchange for her cancelling the SAA flight route to India to pave the way for them to operate it (February, 2019). In 2018, the Judicial Commission of Inquiry into Allegations of State Capture (The Zondo Commission) was established to investigate allegations of state capture.

Like other states across the globe, the ongoing COVID-19 pandemic has had a significant impact on South Africa's health care and education systems and the country's economy. The government has put in place various measures including stimulus packages to assist companies and the most vulnerable. While one would have imagined that this moment would call for sober reflection, some unscrupulous individuals have taken advantage of the situation to carry out corrupt practices particularly in the supply chain of Personal Protective Equipment (PPE), which has manifested in overpricing, substandard products, and awarding tenders to the cronies of government officials and ANC loyalists (DW, 2020). More than 90 companies that were issued purchase orders by the Department of Health and President Cyril Ramaphosa's spokesperson, Khusela Diko, and Gauteng MEC for Health, Bandile Masuku, are currently under investigation (DW, 2020). The pervasive corruption in the country has undermined South Africa's image and moral authority to promote good governance in states such as Zimbabwe and Eswatini. For example, when South Africa attached conditionalities on good governance to R2.4 billion in aid it offered Eswatini, the 
latter rejected the offer, prompting the former to later provide unconditional aid (Tella, 2018b).

\section{Double standards on human rights and the democracy promotion shortfall}

Pretoria's soft power has also been punctured by its inconsistencies on human rights issues. While this has been exacerbated in recent years due to the state's cosy relations with China, it has been a feature of South Africa's post-apartheid foreign policy even during Mandela's years. For example, despite its poor human rights record, South Africa had friendly relations with the autocratic Suharto regime in Indonesia with Mandela visiting Indonesia in 1997 and Suharto undertaking a state visit to South Africa in the same year. In addition, Pretoria supplied weapons to the regime, notwithstanding the possibility of Indonesia using them in the occupied East Timor (Tella, 2018b). While serving as a nonpermanent member of the UN Security Council between 2007 and 2008, the African regional power voted against resolutions that condemned human rights violations in Sudan, Zimbabwe, Iran, and Myanmar on the basis that the West was selectively targeting these states or bypassing UN structures and rules (Habib, 2009). Thus, South Africa departed from the ideals of human rights it claims to represent, which runs contrary to its historical struggle against apartheid, to the chagrin of the international community.

Pretoria's voting behaviour while serving as a non-permanent member of the UN Security Council and its activities at the United Nations Human Rights Council (UNHRC) have further revealed the gap between its rhetoric and action on human rights issues (Hengari, 2018). In the UNHRG, Pretoria abstained from voting on a resolution to set up an international tribunal to prosecute the suspects responsible for the killing of former Prime Minister of Lebanon, Rafiq Hariri, and in 2016 Pretoria voted against a resolution to protect human rights on the Internet (Hengari, 2018). As Hengari notes: "The crisis in its human rights diplomacies undermines its real and perceived normative leadership in Africa and the Global South, as well as its role as a bridge-builder" (2018: 5).

In its ostensible claim for African solutions to African challenges, South Africa turned a blind eye to human rights abuses in states such as Zimbabwe and Sudan. Despite Zimbabwe's notoriety for human rights abuses under Mugabe, South Africa opposed the country's suspension from the Commonwealth in 2002. In the case of Sudan, Pretoria did not fulfil its international obligation as a signatory to the ICC when it failed to arrest Al-Bashir during the AU summit in 2015 in South Africa. Indeed, after the summit, South Africa went on to solidify its relations with Sudan by signing 16 bilateral agreements to the consternation of the ICG (Tella, 2018b). Due to the fact that South Africa was the first African state to adopt the ICC statute in its domestic law in 1998 and its image as a beacon of human rights and the defender of international law, the decision not to arrest Al-Bashir shattered these images, at least in Western eyes. South Africa's commitment to African solutions to African challenges at the expense of human 
rights was challenged by its support of UN Resolution 1973 that symbolised the responsibility to protect Libyan civilians and provided the platform for the North Atlantic Treaty Organization (NATO) to invade Libya in 2011.

Pretoria's relations with Beijing have also dampened its promotion of human rights. An example is South Africa's denial of a visa to Tibetan leader the Dalai Lama to visit the country three times within the space of five years between 2009 and 2014. The proposed visits were to attend a peace conference, Desmond Tutu's eightieth birthday, and the fourteenth World Peace Summit. Afraid of China's wrath, Pretoria denied the Tibetan leader entry and has avoided condemning China's human rights abuses, including in Tibet (Tella, 2018b). It is against this backdrop that Landsberg (2016: 1) notes that, "South Africa's foreign policy is entrapped: it is trapped between Afro-Southern (or Africa-South-South) solidarism, on the one hand, and lofty liberal cosmopolitan values, including human rights, on the other".

South Africa has also sometimes not walked the talk in terms of its foreign policy of democracy promotion as the ANG-led government has had cordial relations with authoritarian regimes such as Libya's Muammar Qadhafi and Cuba's Fidel Castro that supported the fight against apartheid (Landsberg, 2000), Indonesia's Suharto, Iran, and North Korea. The Mbeki administration turned a blind eye to authoritarian regimes in Southern Africa, including Angola, Eswatini, and Zimbabwe. Amidst the human rights abuses and political instability that characterised Mugabe's Zimbabwe, evident in successive flawed elections and forcible seizure of land from White farmers that angered the Western world, resulting in international condemnation and economic sanctions, South Africa, adopted "quiet diplomacy" by not condemning the regime and offering it one billion rand in aid (Khadiagala and Nganje, 2016). With regard to the 2010 Ivorian crisis, incumbent President Laurent Gbabo's rejection of the electoral commission result that declared Alassane Ouattara president was condemned by the Economic Community of West African States (ECOWAS) that resolved to ensure Gbagbo's exit. South Africa's call for a political settlement was viewed as anti-democratic (Tella, 2018b). This undermined Pretoria's moral authority to preach good governance and democratic values across Africa, particularly to states such as Algeria, Libya, and Egypt during the Arab Spring. Khadiagala and Nganje (2016: 1570) observe:

Despite sustained multilateralism, there were few converts to democratic governance and the rule of law at the end of the Mbeki era, signalling the weaknesses in South Africa's power. Although war had been brought to an end in states like Burundi and the DRC, moving towards multiparty democracy remained a serious challenge. At the end of his term, Mbeki's African policy was defined more by Zimbabwe than by the other lofty goals that he had tried to articulate.

The situation is complicated by the fact that South Africa's apartheid past has frustrated its promotion of democracy on the continent as African states often feel 
that it lacks moral authority and experience to preach good governance to the rest of Africa that enjoyed decades of self/majority rule prior to the end of apartheid. This also manifests in the description of South Africa's action as a "Western" project (Landsberg, 2000). Its promotion of democracy has thus been frustrated by fellow African states. For example, Mandela's call to suspend Nigeria from the Commonwealth following the military government of Sani Abacha's human rights abuses, which reached a climax when popular environmentalist Ken Saro-Wiwa and eight fellow activists were executed, fell on deaf ears as other African states did not seem to be prepared to soil their relations with Nigeria, a state that championed decolonisation, the end of minority rule, and African integration, while South Africa was still in the grips of apartheid. African states perceived South Africa as acting as the West's proxy, further puncturing the country's democracy promotion efforts.

A similar dimension is striking a balance between democracy and human rights promotion and the pursuit of economic interests. This has manifested in South Africa's engagement in economic relations with democratic and nondemocratic states alike and sales of arms to states involved in conflicts and noted for human rights abuses (Landsberg, 2000). While it was involved in conflict resolution in the DRC, Pretoria was supplying arms to Burundi and Rwanda who were involved in the conflict (Khadiagala and Nganje, 2016).

In light of South Africa's domestic challenges, there has been internal pressure from both citizens and radical politicians in the ANC-led government to abandon its idealistic and messianic foreign policy that focuses on Africa's renewal, development, security, and integration, and embrace a pragmatic foreign policy that addresses the country's economic interests with a view to addressing domestic constraints, particularly poverty and unemployment (Khadiagala and Nganje, 2016). While this started during the Mandela administration, it became evident in the Zuma years, seen in the administration's neglect of African issues, including democracy and human rights, and its embrace of narrow economic and strategic interests evident in the rapprochement with the BRIC countries and support for President Laurent Gbagbo after he was defeated in the Ivorian presidential elections to the chagrin of Nigeria, ECOWAS, and the international community.

Following former President Zuma's chief mediator Lindiwe Zulu's criticism of Zimbabwe's electoral process, Mugabe described her as "some stupid, idiotic woman". Zuma quickly intervened, reprimanding Zulu for expressing her personal views rather than the official South African position (News 24, 2013: para. 4). Zuma further congratulated Mugabe on his victory at the polls despite the fact that the election was marred by intimidation and irregularities (Tella, 2018b). Rather than South Africa, it was Botswana that criticised the electoral results and called for an independent audit. In the face of South African-led SADC opposition, Botswana soon realised that it was a lone voice and eventually had to toe the line (Khadiagala and Nganje, 2016). There is no doubt that the Zimbabwean situation has had serious consequences for South Africa's soft power derived from its foreign policy of democracy promotion. In a similar vein, Pretoria's promotion 


\section{South Africa}

of democracy in the DRG leaves much to be desired. The Zuma administration prioritised stability and cordial relations with the Kabila administration in pursuit of economic and strategic interests rather than genuine democracy promotion. This is evident in South Africa's approval of the 2011 general elections that were characterised by irregularities and returned Kabila to power (Khadiagala and Nganje, 2016). In 2019, at a media briefing on the Ministerial Panel Report set up by DIRCO, it was noted that in order for Pretoria to remain a force to be reckoned with in African and global affairs, "South Africa must reposition itself as a consistent moral compass and a principled voice of reason in a changing world that is increasingly characterised by selfish and narrow interests" (DIRCO, 2019: 2). It was also highlighted that diplomatic errors had eroded the gains of the past and ultimately resulted in the country's sub-regional, regional, and global decline.

\section{Incessant xenophobia}

The effect of xenophobia on Pretoria's power of attraction cannot be overemphasised. For a state that prides itself on the values of human rights and constitutionalism, persistent xenophobia presents a contradiction. As I have argued elsewhere, while apartheid South Africa's potential soft power was undermined by racism, the democratic South Africa's soft power has been significantly punctured by xenophobia (Tella, 2018b). The attitudinal and violent xenophobia that has characterised the South African landscape has repelled academics, students, tourists, and business owners, undermining the country's image and its economy. Foreigners residing in South Africa have shown little sense of belonging. As the Citizenship Rights in Africa Initiative (CRAI, 2009) noted, although South Africa still attracts a large number of asylum seekers, very few feel that they belong, and the majority have a sense of temporariness and nationhood. For example, in response to the antagonism they experience in South Africa, Nigerian, Congolese, and Zimbabwean nationals have forged social bonds among themselves and have refused to assimilate South African culture. The implication is that these foreigners, who could make a significant contribution, often display ambivalence to the development of the country, have negative sentiments towards South Africa, and do not promote positive narratives about it, all of which damages Pretoria's soft power.

Xenophobia is arguably the single issue that has had the most impact on South Africa's normative depreciation and the deterioration of its nation brand ... The effects of xenophobia signal the most egregious loss of the country's "moral goodness" and the political erosion of its cosmopolitan covenant as articulated through the use of its soft power attributes.

(le Pere, 2017: 108)

Recurrent anti-immigrant sentiments and attacks are a direct consequence of the pervasiveness of xenophobia in the country as politicians, various government 
departments, the media, and the police have all expressed anti-immigrant sentiments. Former President Mbeki's xenophobia denialism, former President Zuma's subtle approval, and former Mayor of Johannesburg Herman Mashaba's explicit comments all reinforce xenophobia (Tella, 2016). The South African media is also culpable. As far back as the 1990s, some media outlets started associating certain nationalities with particular crimes: Nigerians with drugs, Congolese with passport fraud and diamond smuggling, Mozambicans as car hijackers, and Zimbabweans as prostitutes (Tella, 2016). In contemporary South Africa, these immigrants are still perceived in terms of these negative labels. The South African Police and the Department of Home Affairs are notorious for their abuse of African immigrants. Table 4.7 shows South Africa's position in the migrant acceptance index.

Table 4.7 reveals that South Africa is not among the top countries friendly to migrants. While countries such as Rwanda, Sierra Leone, Mali, Nigeria, and Burkina Faso not only fare well in the African context, but are among the most migrant-friendly countries in the world, South Africa ranks 88th globally and 36th in Africa, revealing the high levels of anti-immigrant sentiment. Notwithstanding the fact that the 2008 xenophobic attacks that resulted in the deaths of more than 60 people led to global condemnation, violence against foreigners has continued unabated, exemplified by the 2015, 2017, and 2019 attacks. Aside from this violent manifestation, foreigners are subjected to xenophobic attitudes and policies in their daily lives. South Africa prides itself as a beacon of human rights, yet xenophobic sentiments are often expressed by South African citizens. It is even more worrying that policymakers reinforce anti-immigrant sentiments. In providing justification for the implementation of the e-Toll system on some roads, particularly in Pretoria and Johannesburg, former President Zuma noted that, "We cannot think like Africans in Africa. This is Johannesburg. It is not some national road in Malawi" (Mail \& Guardian, 2013b: para. 1). This is an

Table 4.7 Migrant acceptance index

\begin{tabular}{llll}
\hline African rank & World rank & Country & Migrant acceptance index \\
\hline 1 & 3 & Rwanda & 8.16 \\
2 & 4 & Sierra Leone & 8.05 \\
3 & 5 & Mali & 8.03 \\
4 & 8 & Nigeria & 7.76 \\
5 & 9 & Burkina Faso & 7.74 \\
6 & 12 & Ivory Coast & 7.71 \\
7 & 13 & Benin & 7.67 \\
8 & 19 & Chad & 7.26 \\
9 & 22 & Senegal & 7.17 \\
10 & 25 & Congo & 7.05 \\
36 & 88 & South Africa & 4.98 \\
\hline
\end{tabular}

Source: author's adaptation from Gallup, 2017. 


\section{South Africa}

arrogant display of exceptionalism, which seems to be all too common among South African policymakers and citizens. It is not well received across the continent and damages South Africa's ability to count on Africa's support in promoting its foreign policy objectives, including its quest for a permanent seat on the proposed reformed UN Security Council. It is against this backdrop that le Pere argues that:

South Africa's noble goals in Africa and further afield as well as the celebratory legacy of its transition have been severely compromised and undermined by the treatment of the many foreigners, migrants, and refugees from Africa and other developing countries such as Pakistan and Bangladesh who have come to the country in search of a better life and improved economic prospects.

(le Pere, 2014: 48)

At the launch of Human Rights Watch's 2014 World Report in Johannesburg, its Southern Africa director, Tiseke Kasambala, noted that, "South Africa remains a beacon of hope on the continent, but its human rights legacy is gradually being eroded" (Tella and Ogunnubi, 2014: 159). Article 9 of the United Nations Universal Declaration of Human Rights states that "No one shall be subjected to arbitrary arrest, detention or exile" (United Nations, 2015: 20). The experiences of foreigners who are subjected to inhumane conditions in the Lindela Repatriation Centre near Johannesburg highlight that South Africa does not take this instrument seriously.

Reacting to the 2019 xenophobic attacks, Nigerian Foreign Minister, Geoffrey Onyeama, noted on Twitter: "Received sickening and depressing news of continued burning and looting of Nigerian shops and premises in South Africa by mindless criminals with ineffective police protection. ... Enough is enough" (Krippahl, 2019: para. 2). This incident resulted in the Nigerian and Zimbabwean governments' decision to repatriate around 600 and 170, respectively, of their citizens (Human Rights Watch, 2019). The AU's Peace and Security Council (PSG) organised an impromptu meeting in Addis Ababa to engage the anti-immigrant violence at which South African Ambassador, Ndumiso Ntshinga, condemned the attacks and reiterated the Ramaphosa administration's resolve to address the problem. He called on other African states to assist (Louw-Vaudran and Diatta, 2019). The PSC condemned the attacks, emphasised the need for the South African government to protect immigrants and their property, and offered its support to the government (Louw-Vaudran and Diatta, 2019). In view of the widespread criticism across Africa, Pretoria sent envoys to some African states including Nigeria, Senegal, Ghana, Tanzania, the DRC, and Zambia to try to repair its battered image and apologise to the affected states (Khumalo, 2019). President Ramaphosa stated that the envoys would:

go and explain what has happened and also ... offer our apologies. And for those who have been killed, our condolences, and for those who have been 
injured as well. We have got to do it because our standing on the continent has always been high and this has lowered it quite considerably.

(Khumalo, 2019: para. 3)

It is thus clear that xenophobia has undermined South Africa's credibility in Africa and punctured the country's Pan-African credentials and leadership capacity with a significant impact on the state's soft power. In light of ubiquitous and perpetual xenophobia in South Africa, it is doubtful that the country will be committed to the African Continental Free Trade Agreement (AfCFTA) that seeks to expand intra-African trade and ultimately establish a single continental market and African Customs Union (Lalbahadur, 2019). Pretoria's initial reluctance to sign the treaty is symptomatic of its potential attitude to the agreement. The incessant spate of xenophobic attacks has called into question the Afrocentricity of South Africa's foreign policy and rubbished its African Renaissance, African agenda, and Ubuntu rhetoric and posture. Indeed, "the guiding light of Ubuntu philosophy has come up against the ascendancy of territoriality and privileging of sovereign rights over and above universal human rights" (Mabera, 2017: 32).

Incessant anti-immigrant violence has also led other African countries to call for a boycott of South African companies on the continent (Mabera, 2017) and retaliatory attacks against these companies in states such as Nigeria, Zambia, and the DRG in 2019. Xenophobia has dented South Africa's posture as a Rainbow Nation and damaged its reputation as an immigration state, ultimately undermining its capacity to act as a regional hegemon (le Pere, 2017). While the country still positions itself as a regional power with the wherewithal to champion the African cause in international affairs, incessant xenophobia has undermined Pretoria's ambitions.

\section{The Janus-faced nature of South Africa's relations with Africa versus its relations with the West}

It is important to highlight South Africa's actions and inactions in the international arena that are commended in the West but condemned in Africa and vice versa. Pretoria's stance on gay rights provides an apt example. While Western countries support South Africa's pro-gay rights position, African states rebuff the Southern African country for promoting what they see as acultural to African realities. It is worth noting that many African countries' laws and policies, including those of Nigeria and Uganda, prohibit homosexuality. In 2011, former Zimbabwean President Robert Mugabe asserted that homosexuals are "worse than pigs and dogs .... It becomes worse and satanic when you get a prime minister like Cameron saying countries that want British aid should accept homosexuality" (Onapajo and Isike, 2016: 22). This position matches the stance of most African leaders and from Nigeria to Togo, Uganda, Rwanda, and Zambia, homosexuality is frowned upon, with Africa accounting for 32 of the 72 countries globally that criminalise it (Hairsine, 2019). Given this reality, it is 
difficult for South Africa to defend homosexuality in Africa despite its constitution, which guarantees the rights of minority groups including homosexuals. Indeed, Pretoria's hands are often tied when it comes to condemning anti-gay legislation across the continent, to the chagrin of the West, particularly the United States and its allies. This prompted then President Zuma to assert that, "South Africa respects the sovereign rights of other countries to adopt their own legislation" (Onapajo and Isike, 2016: 34).

In light of the contradictions between its African identity and advocacy for human rights and non-discrimination, South Africa's commitment to international instruments on sexual orientation has oscillated between support and ambivalence. At the 1995 UN World Conference on Women in China, Pretoria advocated for sexual orientation rights, to the consternation of other African delegates. By 2003, South Africa had ceased to offer its support for UN statements on sexual orientation. In 2011, the world witnessed a reverse in South Africa's position, illustrated by its leadership role in the adoption of the Human Rights Council's (HRG) resolution on sexual orientation (Resolution 17/19). In 2016, the African regional power abstained from voting for a UN HRC resolution on the establishment of a watchdog for discrimination and violence against LGBT people. In a nutshell, while South Africa seeks to fight discrimination on the basis of sexual orientation in the international arena in line with its constitutional order, paradoxically Pretoria attempts to avoid the anger of other African states, including Nigeria and Uganda and its BRICS partners with the exception of Brazil (van der Westhuizen, 2016). South Africa's opposition to the UN resolution to decriminalise homosexuality and its inaction regarding the UN HRC's appointment of an independent monitor in 2016 to address violence against gay people (le Pere, 2017) shocked the international community as the African power has one of the most liberal constitutions in the world (le Pere, 2017) and remains one of the few states that have legalised gay marriage. In realisation of the fact that its support - particularly from the early 1990s - for LGBTQ rights offends the sensibilities of the majority of African states, Pretoria has had to soft-pedal. Thus, while the West had hoped that South Africa would lead the campaign to support gay rights, given its liberalism, they have been disappointed by Pretoria's actions and inactions.

South Africa's stance on the ICG is also notable. Pretoria's decision to withdraw from the ICC in 2016 (which was successfully challenged by the South African High Court) followed the court's disappointment and criticism of the country's failure to fulfil its obligations and arrest former Sudan President Omar al-Bashir during his visit to South Africa in 2015. Al-Bashir was wanted by the ICG for crimes against humanity. Pretoria's action in this regard runs contrary to what it stands for. Needless to say, this reaction came as a surprise given South Africa's initial support for the court. It also resulted in many African states rethinking the relevance of the ICG to Africa in light of criticisms levelled against it of targeting African leaders. This is well-founded given the arrest warrants issued for high-profile individuals and serving presidents, including Sudan's alBashir, Kenyan Uhuru Kenyatta, and Libyan Muammar Gaddafi. States such as 
Burundi and the Gambia also attempted to withdraw. South Africa's stance does not run contrary to the AU's position as the fallout between the AU and ICC began in 2009 at the organisation's summit in Libya where the regional body decided not to cooperate with the ICG to arrest Omar al-Bashir. The AU reiterated its position in 2011 when it backed Kenya's request to the UN Security Council to defer the ICC's investigation and prosecution of Uhuru Kenyatta and William Ruto (Khadiagala and Nganje, 2016). Given its racial past, South Africa was among the first countries to join the ICG. Its call for African states' withdrawal seems to contradict the values Pretoria identifies with in the international arena. Although the argument that Africa is the only target has some merit, as van der Westhuizen noted, South Africa could have advanced the establishment of an alternative organisation that deals with human rights abuses in Africa. This would have prevented the U-turn on its commitment to human rights and possible violation of its constitution (van der Westhuizen, 2016).

Another example is South Africa's vote for UN Resolution 1973 that eventually gave NATO the legal basis to invade Libya in 2011. Pretoria and Abuja were heavily criticised by their African counterparts for their position as they were seen as taking the line of the West rather than African solidarity. The challenge posed by the lack of acceptance of South Africa's leadership on the continent also deserves attention. There has been resistance from both democratic and authoritarian regimes, including Nigeria, Angola, Zambia, and Zimbabwe (Ogunnubi and Amao, 2016). This stems from among other things, South Africa's apartheid history, the fact that it is a relatively new player in the international arena and its domestic contradictions of the values it seeks to promote in international affairs including democracy and human rights, and its perception as a stooge of the West.

\section{References}

Akokpari, J. (2018). "Consistency in Inconsistency: South Africa's Foreign Policies in International Organizations." In: Warner, J. and Shaw, T. (eds), African Foreign Policies in International Institutions. New York: Palgrave Macmillan.

Alden, C. and le Pere, G. (2009). "South Africa in Africa: Bound to Lead?" Politikon 36 (1): 145-169.

Alden, C. and Schoeman, M. (2015). "South Africa's Symbolic Hegemony in Africa." International Politics 52 (2): 239-254.

Allison, S. (2016). "Imposing, Aggressive and Unwilling to Listen: How South Africans Are Perceived in Africa." Daily Maverick, March 17. http://www.dailymaverick.co.za/ar ticle/2016-2003-17-imposing-aggressive-and-unwilling-to-listen-how-south-africans-are -perceived-in-africa/\#.VxiD_01DGUk.

April, Y. (2009). "Assessing South Africa's strategic options of soft power application through civic interest groups." African Fournal of Conflict Resolution 9 (1): 123-144.

Barnard, I. (2006). "The Language of Multiculturalism in South African Soaps and Sitcoms." Fournal of Multicultural Discourses 1 (1): 39-59.

Brand Africa (2020). "Brand Africa 100." https://www.brandafrica.net/Rankings.aspx.

Brand South Africa (2010). "Zuma: SA's Most Important Year." http://www.brandsoutha frica.com/governance/developmentnews/zuma-new-year-message. 


\section{South Africa}

Calland, R. and Recht, S. (2015). "Institutional Renaissance or Populist Fandango? The Impact of the Economic Freedom Fighters on South Africa's Parliament." Übersee VRÜ 48 (3): 304-328.

Chiroro, B. (2012). South Africa: Optimising the Currency of Soft Power in the International Arena. Africa Institute for South Africa. Policy Brief no. 79.

Cloete, N., Sheppard, C., and Bailey, T. (2015). "South Africa as a PhD Hub in Africa?" In: Cloete, N., Sheppard, C., and Bailey, T. (eds), Knowledge Production and Contradictory Functions African Higher Education. Cape Town: African Minds, pp. 75-108.

CNBC Africa (2014). "The Changing Global Perception of S. Africa." CNBC Africa, 20 March. www.cnbcafrica.com/news/southern-africa/2014/03/20/the-changing-globa l-perception-of-safrica/.

Cold-Ravnkilde, S. (2019). "Contested Norms in Fragmented Institutions: Gender Equality in South Africa's Development Cooperation." Progress in Development Studies 19 (3): 211-231.

CRAI (Citizenship Rights in Africa Initiative) (2009). "Tolerating Intolerance: Xenophobic Violence in South Africa." http://citizenshiprightsinafrica.org/docs/CRAI SAReportFINAL.pdf

Cybermetrics (2020). "Ranking Web of Universities." https://www.webometrics.info/en/ Ranking_africa.

Department of International Relations and Cooperation (DIRCO) (2019). "Media Briefing on the Ministerial Panel Report 17 April." Pretoria: DIRCO.

Dowse, S. (2011). Power Play: International Politics, Germany, South Africa and the FIFA World Cup. Johannesburg: South African Institute of International Affairs (SAIIA) Occasional Paper No. 82.

DW (2020). "South Africa's Double Blow: Corruption and the Coronavirus." http s://www.dw.com/en/south-africas-double-blow-corruption-and-the-coronavirus/a-544 23065.

February, J. (2019). State Capture: An Entirely New Type of Corruption. Pretoria: ISS.

Freeman, K. (2012). "Sport as Swaggering: Utilizing Sport as Soft Power." Sport in Society 15 (9): 1260-1274.

Gallup (2017). "New Index Shows Least-, Most-Accepting Countries for Migrants." http s://news.gallup.com/poll/216377/new-index-shows-least-accepting-countries-migrants. aspx.

Grix, J. and Lee, D. (2013). "Soft Power, Sports Mega-Events and Emerging States: The Lure of the Politics of Attraction." Global Society 27 (4): 521-536.

Habib, A. (2009). "South Africa's Foreign Policy: Hegemonic Aspirations, Neoliberal Orientations and Global Transformation." South African Fournal of International Affairs 16 (2): $143-159$.

Hairsine, K. (2019). "Why Is Homosexuality Still Taboo in Many African Countries?"4 December. https://www.dw.com/en/why-is-homosexuality-still-taboo-in-many-africa n-countries/a-51528737.

Hardy, S. (2015). "Soft Power South African Style." http://chimurengachronic.co.za/ soft-powersouth-african-style/.

Hengari, A. (2018). South Africa's Hazardous Ballet with Human Rights Diplomacy. South African Institute of International Affairs. Policy Insights 53.

Human Rights Watch (2019). "South Africa: Punish Xenophobic Violence." 13 September. https://www.hrw.org/news/2019/09/13/south-africa-punish-xenophobic-violence.

Institute for Economics and Peace (2020). Global Peace Index 2020: Measuring Peace in a Complex World. Sydney: Institute for Economics and Peace. 
IOL (2019). "Tanzania Urges South Africa to Increase Investments: Presidency." 16 August. https://www.iol.co.za/business-report/international/tanzania-urges-south-a frica-to-increase-investments-presidency-30866672.

Ives, S. (2007). "Mediating the Neoliberal Nation: Television in Post-Apartheid South Africa." ACME: An International E-fournal for Critical Geographies 6 (1): 153-173.

Khadiagala, G. and Nganje, F. (2016). "The Evolution of South Africa's Democracy Promotion in Africa: From Idealism to Pragmatism." Cambridge Review of International Affairs 29 (4): 1561-1581.

Khumalo, T. (2019). "South Africa Deploys Envoys in Wake of Xenophobic Attacks." 16 September. https://www.voanews.com/africa/south-africa-deploys-envoys-wake-xenop hobic-attacks.

Krippahl, C. (2019). "Xenophobia in South Africa Strains International Relations." DW 3 September. https://www.dw.com/en/xenophobia-in-south-africa-strains-internationa 1-relations/a-50275526.

Lalbahadur, A. (2019). "Xenophobia Erodes South Africa's Leadership Potential." 27 May. https://saiia.org.za/research/xenophobia-erodes-south-africas-leadership-poten tial/.

Landsberg, C. (2000). "Promoting Democracy: The Mandela-Mbeki Doctrine." Fournal of Democracy 11 (3): 107-121.

Landsberg, C. (2012). "Afro-Continentalism: Pan-Africanism in Post-Settlement South Africa's Foreign Policy." Journal of Asian and African Studies 47 (4): 436-448.

Landsberg, C. (2016). Caught between Afro-Southern Solidarism and Liberal Cosmopolitan Values: Four Turning points in South Africa's Human Rights Foreign Policy. Occasional Paper Series. Johannesburg: Friedrich Ebert Stiftung, South Africa.

le Pere, G. (2014). Critical Themes in South Africa's Foreign Policy: An Overview. Strategic Review for Southern Africa 36 (2): 31-56.

le Pere, G. (2017). "Ubuntu as Foreign Policy: The Ambiguities of South Africa's Brand Image and Identity." Strategic Review for Southern Africa 39 (1): 93-115.

Louw-Vaudran, L. and Diatta, M. (2019). "Can South Africa Repair Its Image Damaged by Xenophobia?"16 September. https://issafrica.org/iss-today/can-south-africa-repa ir-its-image-damaged-by-xenophobia.

Mabera, F. (2017). "The Impact of Xenophobia and Xenophobic Violence on South Africa's Developmental Partnership Agenda." Africa Review 9 (1): 28-42.

Mabera, F. (2018). "South Africa's Profile as Peacekeeper: In Keeping with the Times?" African Security 11 (3): 223-251.

Mada Masr (2013). "Egypt Reacts Angrily to South African Criticism." Mada Masr, 31 July. Available at https://www.madamasr.com/en/2013/07/31/news/u/egypt-rea cts-angrily-to-south-african-criticism/.

Madise, D. and Isike, C. (2020). "Ubuntu Diplomacy: Broadening Soft Power in an African Context." Fournal of Public Affairs. doi:10.1002/pa.2097.

Mail \& Guardian (2013a). "South Africa Is 'Immature', Says Swaziland." Mail \& Guardian, 31 July. http://mg.co.za/article/2013-07-31-south-africa-is-immature-says-swazila nd-spokersperson.

Mail \& Guardian (2013b). "Zuma: Don’t Think Like an African - Pay Up for E-tolls.” 22 October. https://mg.co.za/article/2013-10-22-zuma-dont-think-like-an-african-pay-up -for-e-tolls/.

Mandela, N. (1993). "South Africa's Future Foreign Policy." Foreign Affairs 72 (5): 86-97.

Masters, L. (2015). "South Africa's Emerging Parliamentary Diplomacy and Soft Power." Strategic Review of Southern Africa 37 (2): 74-93. 
Masters, L. (2017). "South Africa's Post-Apartheid Foreign Policy Making and the Role of the President." Politeia 36 (1): 1-21.

Moore, C. (2014). "What Mbeki Did Next: Continuities in the Presidential and Post-presidential Diplomacy of Thabo Mbeki." South African Fournal of International Affairs 21 (2): $161-175$.

MTN (2019). "Summary of MTN Nigeria Unaudited Results for the Six Months Ended 30 June 2019." 26 July. https://www.mtn.com/summary-of-mtn-nigeria-unaudite d-results-for-the-six-months-ended-30-june-2019/.

MTV Africa (2015). "MAMA 2015 Awards." http://mama.mtv.com/news/2015-mtv-a frica-music-awards-winners/.

National Planning Commission (2011). National Development Plan 2030: Our Future - Make It Work. Pretoria: South Africa's National Planning Commission.

Ncube, G. (2019). "Gender and Naming Practices, and the Creation of a Taxonomy of Masculinities in the South African Soap Opera The Queen." Nomina Africana 33 (1): $1-8$.

Ndlovu, S. (2010). "Sports as Cultural Diplomacy: The 2010 FIFA World Cup in South Africa's Foreign Policy.” Soccer \& Society 11 (1/2): 144-153.

News24 (2013). "Robert Mugabe cannot be blamed for name-calling." 13 December. www.news24.com/Archives/City-Press/Robert-Mugabe-cannot-be-blamed-for-name-c alling-20150429.

News24 (2017). "Xenophobia Fears: Fewer African Students Enrolling at SA Universities." 9 June. http://m.news24.com/news24/Africa/News/xenophobiafears-fe wer-african-students-enrolling-at-sa-universities-20170608.

Nkoana-Mashabane, M. (2016). "Budget Vote Speech. Cape Town, 3 May." Available at: www.dfa.gov.za/docs/speeches/2016/mash0503.htm.

Nussbaum, B. (2003). "African Culture and Ubuntu: Reflections of a South African in America." Perspectives 17 (1): 1-12.

Nye, J. (2004). Soft Power: The Means to Success in World Politics. New York: Public Affairs.

Nye, J. (2012). "What's wrong with transformational leadership?." China Daily. 9 March. http://www.chinadaily.com.cn/opinion/project/2012-03/09/content_147997 54.htm.

Ogunnubi, O. (2020). "South Africa's Soft Power and the Diplomacy of Nuclear Geopolitics." Geofournal. doi:10.1007/s10708-020-10252-x.

Ogunnubi, O. and Amao, O. (2016). "South Africa's Emerging 'Soft Power' Influence in Africa and its Impending Limitations: Will the Giant be able to Weather the Storm?" African Security 9 (4): 299-319.

Ogunnubi, O. and Okeke-Uzodike, U. (2015). "South Africa's Foreign Policy and the Strategy of Soft Power." South African Fournal of International Affairs 22 (1): 23-41.

Ogunnubi, O. and Tella, O. (2017). "Framing South Africa's Soft Power through Non-State Sources." Strategic Analysis 41 (5): 478-495.

Okayafrica (2016). "The Full List of MTV Africa Music Awards 2016 Winners." https:// www.okayafrica.com/mtv-africa-music-awards-2016-winners-mtvmama2016/.

Olivier, G. (2003). "Is Thabo Mbeki Africa's Saviour?” International Affairs 79 (4): 815-828.

Onapajo, H. and Isike, C. (2016). "The Global Politics of Gay Rights: The Straining Relations between the West and Africa." The Fournal of Global Analysis 6 (1): 21-45.

Prinsloo, B. (2019). "South Africa's Efforts to Project Influence and Power in Africa: 2000 to 2017." Strategic Review for Southern Africa 41 (1): 23-53.

Public Protector (2014). Secure in Comfort: Report on an Investigation into Allegations of Impropriety and Unethical Conduct Relating to the Installation and Implementation of Security Measures by the 
Department of Public Works at and in Respect of the Private Residence of President Facob Zuma at Nkandla in the KwaZulu-Natal Province. Report No. 25. Pretoria: Public Protector.

Qobo, M. and Nyathi, N. (2016). "Ubuntu, Public Policy ethics and Tensions in South Africa's Foreign Policy." South African Fournal of International Affairs 23 (4): 421-436.

Schoeman, M. (2015). "South Africa as an Emerging Power: From Label to 'Status Consistency?" South African Fournal of International Affairs 22 (4): 429-445.

Sehoole, C. (2015). "International Students Love South Africa, but Xenophobia Could Ce a Heartbreaker." The Conversation, 21 May. Available online at: https://theconversation. com/international-students-love-south-africa-but-xenophobia-could-be-a-heartbreaker41707.

Sidiropoulos, E. (2014). "South Africa's Emerging Soft Power" Current History 113 (763): $197-202$.

Singh, R. (2013). "Examining Xenophobic practices amongst University Students - A case study from Limpopo Province." Alternation Special Edition (7): 88-108.

South African Government (2011). "Building a Better World: The Diplomacy of Ubuntu: White Paper on South Africa's Foreign Policy." https://www.gov.za/sites/default/ files/gcis_document/201409/foreignpolicy0.pdf.

South African Government (2020). "Minister Tito Mboweni: Media Briefing on Economy and Coronavirus Covid-19." 14 April. https://www.gov.za/speeches/minister-tito-m boweni-media-briefing-economy-and-coronavirus-covid-19-14-apr-2020-0000.

Southern Africa - Towards Inclusive Economic Development (SA-TIED). (2020). "Impact of Covid-19 on the South African Economy: An Initial Analysis." Working Paper 111. http s://sa-tied.wider.unu.edu/article/impact-covid-19-south-african-economy-initial-analysis.

Spooner, S. (2014). "South Africa Universities Winning Race for Africa's Students: Here Are Their Secrets and Deals You Need to Know About." Mail \& Guardian, 15 September. http://mgafrica.com/article/2014-09-11-why-south-africas-universities-offer-a fricas-studentsthe-best-options-and-the-tricks-they-need-to-know.

Statistics South Africa (Stats SA). (2017). Poverty Trends in South Africa: An Examination of Absolute Poverty between 2006 and 2015. Pretoria: Statistics South Africa.

Tella, O. (2016). "Understanding Xenophobia in South Africa: The Individual, the State and the International System." Insight on Africa 8 (2): 142-158.

Tella, O. (2017). "South Africa in BRICS: The Regional Power's Soft Power and Soft Balancing." Politikon 44 (3): 387-403.

Tella, O. (2018a). "South African Higher Education: The Paradox of Soft Power and Xenophobia." In: Akinola, A. (ed.), The Political Economy of Xenophobia in Africa. Cham: Springer.

Tella, O. (2018b). "Currencies, Constraints and Contradictions of South Africa's Soft Power." Journal of Asian and African Studies 53 (3): 420-436.

Tella, O. (2019). Revisiting the Georgetown Agreement: Comparative Region-building in Africa, the Caribbean, and the Pacific. Policy Brief 4. Johannesburg: Institute for Pan-African Thought and Conversation.

Tella, O. (2020). "Soft Power Individuals in Nigeria and South Africa: An Appraisal of Olusegun Obasanjo's and Thabo Mbeki's Power of Attraction." The Round Table 109 (5): 574-585.

Tella, O. and Ogunnubi, O. (2014). "Hegemony or Survival: South Africa's Soft Power and the Challenge of Xenophobia." Africa Insight 44 (3): 145-163.

The Brenthurst Foundation (2020). How to Turn Crisis into Opportunity After Covid-19: Choices for a Better South African Future. Discussion Paper 3. Johannesburg: The Brenthurst Foundation. 


\section{South Africa}

Times Higher Education (2020). "Best Universities in Africa 2020." https://www.timeshigh ereducation.com/student/best-universities/best-universities-africa.

Turpin, A. (2019). "The Grand Inga Dam Project Poses Fiscal Risks Similar to the Controversial Arms Deal." Daily Maverick, 13 December. https://www.dailymaverick.co. za/article/2019-12-13-the-grand-inga-dam-project-poses-fiscal-risks-similar-to-the-contr oversial-arms-deal/.

United Nations (2015). Universal Declaration of Human Rights. New York: United Nations. van der Westhuizen, J. (2016). "South Africa's Soft Power Conundrum: How to Win Friends and Influence People in Africa." Journal of Political Power 9 (3): 449-465.

van Wyk, J. (2014). "Playing in the Orchestra of Peace: South Africa's Relations with Iraq (1998-2003)." South African Fournal of International Affairs 21 (2): 193-211.

The World Bank (2018). South Africa Economic Update: Fobs and Inequality. Washington, DC: World Bank.

World Economic Forum (2019). "These Countries Have the Most Women in Parliament." https://www.weforum.org/agenda/2019/02/chart-of-the-day-these-countries-have-themost-women-in-parliament/. 


\section{Egypt \\ The resilient pharaoh}

\section{Introduction}

There is no gainsaying that Egypt is a pivotal state in the Middle East. This manifests on many levels. It is an important ally of the West, serving as a major market for Western countries' exports and a source of energy to its Western partners. More importantly, Egypt is critical in guaranteeing stability in the Middle East, given its important role in the region's peace process. Cairo's status in this regard emanates from both its hard and soft power. In terms of hard power, it has a huge population (around 100 million, the third largest in Africa and the largest in the Middle East) (ElSebaie and Mouawad, 2014); is the third largest economy in Africa (behind Nigeria and South Africa); and ranks as the number one military power on the continent (World Bank, 2019a; Global Fire Power, 2020). With regard to its soft power, Egypt's philosophy of Pharaonism, its culture promoted by its skilled workers and the Mohammed Salah effect, its brand of Pan-Arabism and diplomatic engagement are noteworthy.

However, post the 2011 Arab Spring, Egypt declined in both dimensions of power. This has been complicated by the country's domestic challenges including political instability and human rights abuses, thanks to the role of the military and Muslim Brotherhood; and economic challenges that have manifested in high levels of poverty and unemployment. The effect of these domestic bottlenecks is seen in Cairo's declining geo-political influence.

\section{The rise of Egypt's soft power}

\section{Pharaonism, Nasser's Pan-Arabism, and contemporary Pan-Arabism}

\section{Pharaonism}

Pharaonism attracts many tourists to Egypt each year to view the antiquities in the country's museums, especially in Cairo and Alexandria, whose depictions of the pharaonic past leave visitors in awe. Its history, cultural significance, and symbolic structures like the pyramids, mummies, and hieroglyphs place ancient Egypt in universalist narratives (Riggs, 2013). This has had a significant impact

DOI: $10.4324 / 9781003176022-5$ 


\section{Egypt}

on Egypt's economy as tourism contributes a significant share of the country's GDP and labour force. For example, in 2019 Egypt earned $\$ 29.5$ billion from travel and tourism, the highest pickings in Africa, followed by South Africa at $\$ 24.6$ billion and Nigeria at $\$ 18.1$ billion (World Travel and Tourism Council, 2020). Table 5.1 shows the top ten countries in the world in relation to job creation resulting from the travel and tourism sector.

In recent times, Pharaonism has declined in Egypt, partly due to the rise of the Salafi movement that portrays pharaonic statutes as idolatrous and some in the West that perceive ancient Egypt as a myth (Riggs, 2013). However, Pharaonism has challenged the narrative of Western knowledge of ancient Egypt as boring classification and mythological fantasy (Lietzelman, 2014-2015). Beyond its intellectual value, Pharaonism provided a political and legal framework for Egypt's decolonisation (Lietzelman, 2014-2015) and in the face of neo-colonialism, it remains significant in contemporary nationalism, identity, decolonisation, and decoloniality projects. In other words:

Pharaonism reclaimed the iconography that the West had used to reduce Egypt to a Neolithic wonder overrun by backward Ottomans incapable of admiring their own history, and then it employed this iconography to demonstrate the ancient indigeneity and rightfulness of Egyptian independence.

(Lietzelman, 2014-2015: 51)

While Egypt has always been known for its rich history, the discovery of King Tutankhamen's tomb ignited significant interest in its pharaonic past and its artifacts among academics and observers (Colla, 2007). Beyond Africa, this discovery sparked a desire for pharaonic themes, styles, cinema, and literature (Colla, 2007). As Colla (2007: 177-178) asserts:

Table 5.1 The ten countries with the highest number of jobs created in the travel and tourism sector

\begin{tabular}{cll}
\hline Rank & Country & Total jobs in millions \\
\hline 1 & India & 6.36 \\
2 & China & 5.47 \\
3 & Philippines & 2.53 \\
4 & Indonesia & 1.95 \\
5 & Japan & 1.37 \\
6 & Thailand & 1.21 \\
7 & Mexico & 1.18 \\
8 & UK & 0.99 \\
9 & Egypt & 0,69 \\
10 & Vietnam & 0.66 \\
\hline
\end{tabular}

Source: World Travel and Tourism Council, 2020. 
Thus the significance of the discovery of Tutankhamen - Tut - goes well beyond the science of Egyptology to reach the entire range of political and expressive cultures in Egypt, from architecture to literature, from nationalist politics in the new Parliament to how Egyptian elites negotiated issues of sovereignty under British occupation.

Pharoanism also celebrates Egyptian national identity, which distinguishes it from other Arab countries (Miccoli, 2012) and reinforces the country's role as a cradle of civilisation while other nations were in barbarism. In light of the negativity that characterises the portrayal of Africa in the global media, Pharaonism promotes an understanding that Egypt once civilised the world, served as the cynosure of global eyes and, most importantly, was superior to other nations. This is a significant exercise of soft power.

While the use of Pharaonism has evolved and diversified over the years from anti-colonialism to nationalism, and Pan-Arabism (Aboul-Ela, 2010), the bottom line is that it challenges narratives of Egypt as a backward nation and showcases the achievements of ancient Egypt. Against this backdrop, while one would have expected that the pharaonic past characterised by its monuments, artifacts, pyramids, temples, hieroglyphs, tombs, and gold would have a dominant influence on contemporary Egypt in the process of nation-building, modern Egypt draws more from its Islamic past and Pan-Arabism. This has prompted scholars such as Colla (2007) and Wood (1998) to engage the place of Pharaonism in Egypt today in the realms of art, literature, education, and politics. For example, as a symbol of Egyptian nationalism, Pharaonism has manifested in art, literature, education, and most importantly as political action (Wood, 1998).

\section{Nasser's Pan-Arabism}

Although the post-independence Arab states were weak, Egypt began to thrive during the $1950 \mathrm{~s}$, a period in which it stood tall among its contemporaries due to its large population, Gross National Product and army, and the fact that it accounted for the highest military expenditure in the Arab world (Hinnebusch, 2013). In addition, it had a sophisticated bureaucracy, and was the most stable and coherent Arab state. This positioned Cairo as a potential hegemon in the region. This remarkable domestic base propelled then Egyptian President, Gamal Abdel Nasser, to challenge Western hegemony in the Middle East and North Africa (MENA) region and to provide an alternative Egyptian hegemony rooted in a Pan-Arab order (Bahgat, 2007). It should be noted that, while Egypt's hard power dwarfed that of its contemporaries, its influence was not significantly derived from this source as it failed to project its power through military and economic threats or sanctions. In other words, rather than its coercive capability, Egypt's influence in this period was largely derived from its attractive capacity. El Rehim (2017) notes that Egypt's status as a regional power stems from its soft power that is encompassed by its renowned ancient civilisation. Hinnebusch (2013: 78-79) observes that: 


\section{Egypt}

Rather, its hegemony was based on Nasser's asymmetrical ability to project trans state ideological influence, using Radio Cairo to politically mobilise the emerging middle classes; especially as his foreign policy victories against the West - notably the Czech arms deal, his successful stand against the Baghdad Pact, and the Western failure at Suez - transformed him into a Pan-Arab hero.

Nasser effectively used the media, especially radio, to project Egypt's soft power. Sawt al-Arab (The Voice of the Arabs) broadcasted to 18 Arab countries. Radio not only enhanced Egypt's image but also promoted Pan-Arabism in these countries. It was also instrumental in exposing Arab governments that were not fully committed to Pan-Arab ideas to the Arab public, thereby, instigating public dissidence. For instance, Sawt al-Arab's criticism of then Prime Minister of Iraq, Nuri al-Said, over his negotiation of the 1955 Baghdad Pact - a military and political agreement with the West - contributed to the execution of the Prime Minister and the overthrow of his government by military officers (Rubin, 2010). Nasser was noted for his powerful speeches that were widely aired across the Middle East and resonated with many Arab citizens. Indeed, his speeches were so powerful that they caused riots in the region (El Rehim, 2017). "In short, Egypt not only became the beating heart of the Arabs but also the maker of their conscience and their modern soul" (Nafi, 2017: para. 21).

Nasser was successful in his advocacy of Pan-Arabism that calls for Arab states to rally round Egypt to challenge Israel and the Western powers. In simple terms, Egypt set the agenda of Pan-Arabism. It provided the model for other Arab states by acting as a norm entrepreneur of Pan-Arabism and determining the regional order, particularly in relation to Israel and Palestine on the one hand, and the West on the other (Rubin, 2010). It is in light of this that El Rehim (2017) argues that the late 1950s and early 1960s marked the golden age of Egypt's soft power. Rubin (2010: 9) observes that "Egypt's soft power, both past and present, draws upon its rich cultural, intellectual, and political legacy as the birthplace and launching pad for Arab nationalism, political Islam, liberal Islamic political thought and Islamic extremism." This engendered the rise of movements against and the overthrow of Western-backed regimes in the region, culminating in the fall of Hashemite Iraq (Hinnebusch, 2013). Egypt's influence during this period prompted Nasser to note that:

For some reason it seems to me that within the Arab circle there is a role, wandering aimlessly in search of a hero. And I do not know why it seems to me that this role, exhausted by its wanderings, has at last settled down, tired and weary, near the borders of our country and is beckoning to us to move, to take up its lines, to put on its costume, since no one else is qualified to play it. We alone, by virtue of our place, can perform the role.

(Bahgat, 2007: 414)

While Nasser's Pan-Arab ideas reverberated across the Middle East, there were instances where Arab states, particularly conservative regimes (monarchies), 
disagreed on what should constitute Pan-Arab norms and the nature of the relationship with the West and Israel, no doubt due to the apparent threat the ideas posed to the survival of their regimes. For instance, King Faisal of Saudi Arabia was convinced that Nasser's Pan-Arabism was detrimental to the survival of the ruling class (Tsourapas, 2018a). This disagreement between the Arab republics and the Arab monarchies culminated in what was tagged the Arab Cold War, which was evident in Egypt's and Saudi Arabia's support for opposing sides during the 1962-1970 civil war in Yemen (Tsourapas, 2018a). In the Yemeni conflict, alongside its soldiers and military armaments, Egypt mobilised hundreds of teachers, advisers, and doctors to offer development aid. Egyptian newspapers that were distributed across the Middle East aimed at winning the hearts and minds of their audience, particularly at the height of the Arab Cold War, and the Egyptian state offered university scholarships to Arab students in a bid to encourage them to embrace Pan-Arabism (Tsourapas, 2018a). The salience of Egypt's soft power in Yemen is perhaps best captured by New Tork Times' correspondent Dana Adams Schmidt, who observed:

I was impressed also by the extent of the Egyptians' "hearts and minds" campaign among the Yemenis [such as] installing water pumps, schoolteaching and providing all kinds of professional services and advice - agricultural, engineering and medical. These were all ways of introducing the Yemenis to modern life, ways in which the Egyptians could do things for the Yemeni people which their traditional leaders could not. The Egyptians had also brought 100 Egyptian ulema [Islamic scholars] into the country, in the hopes of persuading the Yemenis that there were really no important differences between the Sunnis and the Shia in general, and the Shaffei and Zeidi sects in particular. They may even have tried to persuade the Zeidis that they did not really need an Imam.

(Tsourapas, 2018a: 411)

Nasser's Pan-Arabism came to an end when Egypt was defeated in the Arab-Israeli war in 1967. The war not only decimated Egypt economically but also ideologically, and it became increasingly dependent on the emerging powers in the Middle East (Hinnebusch, 2013). By the 1970s, Egypt's edge had dwindled as states such as Saudi Arabia and Iraq rose to become important actors in the Middle East due to the oil boom amidst challenges such as deficient military capacity and a small population in the case of Saudi Arabia, and a weak domestic base that hinged on identity in the case of Iraq (Hinnebusch, 2013). However, Egypt's 1979 peace treaty with Israel is arguably one of the most important agreements in the efforts to guarantee Arab-Israeli peace.

\section{Contemporary Pan-Arabism}

There is a lack of consensus on the hegemony of Arabism in contemporary Middle East politics. While some scholars note the decline of Arabism in the 
region, others continue to underline its significance in Middle East politics (Monier, 2014). Before the Arab Spring, Egypt's relative decline and the seeming rise of Turkey's and Iran's soft power led to the assumption that a new regional order championed by non-Arab states would emerge. However, the Arab Spring shattered that assumption as the uprising rekindled Pan-Arabism (Monier, 2014). This gives Egypt an edge because, although Iran and Turkey have a Muslim majority, they are not Arab countries. Up until today, Egypt's narrative of PanArabism has held sway in the Middle East, despite its decline in material terms and the rise of states like Turkey and Iran. Monier (2014) notes that "non-Arab powers face an ethnic barrier, and in the case of Iran a sectarian barrier too in relation to the arguably hegemonic Arab discourse of the regional order". Thus, Egypt continues to play a leadership role in the Arab world, albeit to a lesser extent than prior to the Arab Spring.

Turkey and Iran have attempted to adopt regional discursive hegemony Islam and a democracy model (in the case of Turkey) - to boost their leadership status in the region. While this occurred before the uprising, they sought to take advantage of the opportunity provided by the Arab Spring to achieve this objective. However, Egypt's narrative discourse as the leader of Pan-African unity and stability in the Middle East undermined Turkey and Iran's narrative (Monier, 2014).

\section{Skilled workers}

During Nasser's administration, the influx of Egyptians across Arab and African states was enhanced by a deliberate state emigration policy that subsidised shortterm emigration of highly skilled workers, including doctors, nurses, and teachers, who were loyal supporters of the state to promote the government's foreign policy objectives (Tsourapas, 2018a). This served as a platform for cultural diplomacy aimed at spreading Pan-Arab ideas and promoting bilateral aid, especially in Africa (Tsourapas, 2018a). In Africa, Egypt sought to achieve two objectives, namely, to garner African states' support at the UN, and to counter Israel's influence on the continent (Tsourapas, 2018a). In the Arab world, the influx of Egyptian professionals was facilitated by the region's dire need for skilled workers to develop the newly independent states, particularly the bureaucracy and education, following the end of British colonial rule. Egypt was well positioned to take maximum advantage of the situation and by extension augment its soft power (Tsourapas, 2018b). This is not to suggest that there was no domestic skills shortage in Egypt. However, the country was prepared to sacrifice its domestic needs to assist the region. The fact that emigration to this region ran contrary to the Nasser's administration's restricted and regulated migration is noteworthy. Prior to their departure, these professionals were trained and indoctrinated by the Egyptian government in order to ensure that they painted their country in a positive light and promoted its foreign policy objectives in their host countries. Many of these workers' salaries were paid by the Egyptian government, easing the financial burden on the host countries. 
The impact of Egyptian professionals is illustrated by the fact that the British were concerned about the potential of Egyptian teachers soiling the reputation and interests of the Great Power in Libyan schools, which were using Egyptian textbooks (Tsourapas, 2018a). A chapter in a seventh-grade textbook titled "I am an Arab" is illustrative. It states, "I am an Arab. Yes, I say it with all pride and happiness. I am not alone. Every Arab is my brother in language, religion, feeling and nationhood .... Yes, I am an Arab from Libya" (Tsourapas, 2018a: 406). Indeed, Libya's first university - the Libyan University - was run by Egyptians when it was established.

Thanks to Egyptian professionals, especially teachers, Nasser's Pan-Arabism was visible in places such as Bahrain, Dubai, and Iraq, where these professionals ignited the political and cultural consciousness of the people of these countries, displaying Nasser's photographs and speeches in many classrooms. Egyptian professionals were equally visible in major government sectors across the Arab world (Tsourapas, 2018a).

Egyptians began to migrate from the 1960s for economic and to a lesser extent political reasons, mainly to the Gulf States (Zohry, 2014). While emigration was critical to ease pressure on the domestic labour market during this period, since the 1980s it has become an instrument for development, including remittances which are one of the largest sources - larger than Foreign Direct Investment (FDI) or official aid - of Egypt's foreign exchange (Zohry, 2014). As far back as 1979 , remittances accounted for $\$ 2$ billion, which was equal to the receipts from cotton exports, Suez Canal transit fees, and tourism, and averaged 6 per cent of the country's GDP between 1990 and 2011 (Zohry, 2014). This makes Egypt one of the top recipients of remittances in the world and has contributed to the country's economic diplomacy. Table 5.2 shows the top ten recipients of remittances in 2018.

Before the 2010-2011 Arab Spring, Saudi Arabia accounted for 50 per cent of Egyptian migrants, while Kuwait, Libya, and Jordan accounted for 40 per cent,

Table 5.2 Top ten remittance recipients in 2018

\begin{tabular}{cll}
\hline Rank & Country & Amount (\$ billion) \\
\hline 1 & India & 78.6 \\
2 & China & 67.4 \\
3 & Mexico & 35.7 \\
4 & Philippines & 33.8 \\
5 & Egypt & 28.9 \\
6 & Nigeria & 24.3 \\
7 & Pakistan & 21.0 \\
8 & Vietnam & 15.9 \\
9 & Bangladesh & 15.5 \\
10 & Ukraine & 14.4 \\
\hline
\end{tabular}

Source: author's adaptation from World Bank, 2019b. 
with Egypt having an estimated 6.5 million people in the diaspora (International Organisation for Migration, 2010; Zohry, 2013). Beyond the Arab countries, the United States, Canada, Italy, Australia, and Greece, and to a lesser extent the UK, the Netherlands, France, Germany, and Spain account for a large number of Egyptian migrants (International Organisation for Migration, 2010).

In recent times, Cairo's emigration policy has focused on bilateral collaboration, especially with the oil producing Arab states (Adamson and Tsourapas, 2019). While Egyptian workers in countries such as Libya and Jordan work in construction, agriculture, and services, those in the Gulf States are employed in diverse fields including accountancy, marketing, agriculture, and animal husbandry (De Bel-Air, 2016). These migrants, particularly the highly skilled, serve as a veritable source of symbolic nation-building and public diplomacy as the Egyptian government often uses rhetoric and symbols to communicate the achievements of Egyptians abroad, one of which is "Sons of Egypt Abroad" (Dawood, 2012). Egypt also honours highly skilled Egyptians abroad such as Hany Azir, the engineer who constructed the Berlin Hauptbahnhof in Germany (Dawood, 2012). In 2016 there were more than six million Egyptians across the MENA region, especially in Saudi Arabia, Jordan, and the UAE, and three million in Europe, North America, and Australia (Tsourapas, 2018b). Egypt is also perceived as a veritable destination for thousands of African and Arab migrants and serves as a transit country for sub-Saharan Africans crossing to Europe via the Mediterranean (Tsourapas, 2018b). The country's migration policy thus serves the dual purpose of economic and cultural diplomacy.

\section{The Mo Salah effect and sport diplomacy}

Egypt prides itself on its achievements in sporting activities. The influence of some of its sportsmen and women radiates beyond the field of play. In 2019, Egypt achieved a remarkable feat. Mohammed (Mo) Salah was the top scorer in the English Premier League and won the Union of European Football Associations (UEFA) Champions League with his team (Liverpool), and Egypt accounted for the top four men and women in the Professional Squash Association (PSA) world rankings. The country won the men's Youth World Handball Championship and achieved 254 medals in the African Games in Morocco, an all-time record (American Chamber of Commerce in Egypt, 2019). Among its sportsmen and women, Mohammed Salah is by far the most influential, seen in his recognition by Time Magazine as one of the 100 Most Influential People in 2019 (Time Magazine, 2019).

Recognition of Salah's global influence in his home country is illustrated by the description of the soccer player as "a source of national pride and happiness. You are a true inspiration to the youth of Egypt and Africa, an icon of Egypt's soft power" by foreign ministry spokesperson Ahmed Abu Zeid (Egypt Today, 2018: para. 2). Sisi weighed in, noting that "What he has accomplished calls for pride and affirms Egyptians' capabilities in all fields ... Proud of him every Egyptian who holds Egypt's name high” (Super Sport, 2018: para. 7). 
Salah's achievements are remarkable. At just 29, he won: the CAF African Footballer of the Year award in 2017 and 2018; the English Premier League Professional Footballers' Association (PFA) Player of the Year award in 2018; and the UEFA Champion's League trophy in 2019. He was the top goal scorer in the English Premiership in 2018, and joint top scorer (alongside Senegal's Saido Mane and Gabon's Pierre-Emerick Aubameyang) in 2019, and won the English Premiership trophy in 2020. His role was critical in qualifying Egypt for the country's first FIFA World Cup in 28 years in Russia in 2018. However, he, and by extension the Egyptian team, could not make any significant impact during the tournament due to the injury he sustained while playing for Liverpool in the UEFA Champions League prior to the World Cup. A comprehensive study by Alrababa'h et al. (2019) shows that, due to Mo Salah's influence, there was an 18.9 per cent drop in hate crimes in Merseyside County where Liverpool Football Club is located. The research further revealed that the rate at which Liverpool fans post Islamophobic tweets has dropped by half since the arrival of Mohammed Salah in Liverpool in 2017. Following Liverpool's victory over FG Porto in the UEFA Champion's League in February 2018, the former's fans chanted:

If he scores another few
Then I'll be Muslim, too
If he's good enough for you
He's good enough for me
Sitting in a mosque ...
That's where I wanna be.
(Alrababa'h et al.,
2019: 1)

During the same season, Liverpool fans chanted:
Mohamed Salah
A gift from Allah ...
He's always scoring
It's almost boring
So please don't take
Mohammed away.
(Alrababa'h et al., 2019: 1)

It is clear that Mohammed Salah is identified with Islam in a country where 90 per cent of the population identify themselves as Christian or non-religious and where there is a high level of discrimination against Muslims, particularly following the September 11, 2001 terrorist attacks in the United States. Clearly, Salah has influenced some of these individuals to convert to Islam. One such 
person is Ben Bird, a Nottingham Forest season-ticket holder. He noted that "I can be myself but because I made the declaration of faith I'm a Muslim. I'm still me and that's what I took from Mohamed Salah" (Bird, 2019: para. 1). Bird added that:

I'm embarrassed to say this but my opinions on Islam used to be that the religion, the culture and the people were backward; that they didn't integrate and wanted to take over. I always looked at Muslims like the elephant in the room. I had a hatred of Muslims .... When Salah scores I think he's scoring for the faith. When he won the Champions League I said to my friend that was a victory for Islam. After each of his goals Salah practises the sujood (prostration) and exposes a very Islamic symbol to the world. How many people watch the Premier League every week? Millions globally.

(Bird, 2019: para. 3 and 14)

Salah's Islamic practice during Liverpool's matches, such as prostrating to say Muslim prayers after scoring, has highlighted Muslim practices in the hearts and minds of his fans. The Salah effect is also seen in the inclusion of this practice in the FIFA 2019 video game, which is played by millions of youth across the globe (Alrababa'h et al., 2019). Salah's Islamic practice on the global stage of international soccer is arguably unprecedented, resulting in a positive portrayal of Islam and consequently reducing Islamophobia in England (Alrababa'h et al., 2019) and possibly beyond. Aside from his goal scoring ability, Salah's technique, astuteness, charisma, and humility on the field are equally important. It is against this backdrop that he has been compared to football's arguably greatest players, Lionel Messi and Christiano Ronaldo. Salah's image as a friendly celebrity, responsible father, and amiable teammate, and his aura on and off the field, challenge negative perceptions of Muslims as terrorists and violent people across Europe. As Alrababa'h et al. (2019: 31-32) assert, "the public image of Salah as a hero of sorts, and the resulting normalization of some Muslim identities practices, may have dampened the appetite for harassment and violence toward the city's Muslims". It is therefore not surprising that Salah featured in Time Magazine's 100 Most Influential People in 2019. The magazine described him as "a better human being than he is a football player. And he's one of the best football players in the world" (Time, 2019). In light of such admiration, Salah's influence seems to be more powerful than the Egyptian government's official rhetoric, speeches, and ideological slogans (al-Dosary, 2018). He is thus well placed to promote Egypt's Pan-Arabism and the country's foreign policy objectives. However, it remains to be seen if Cairo will effectively use Salah to deploy celebrity diplomacy to promote the country's national interests in the international arena.

\section{Culture and entertainment}

Many artists from the MENA region migrate to Egypt to make a name for themselves in the entertainment industry as Cairo has been the main hub of 
entertainment since the late 1930s. Thus, Egypt offers a Pan-Arab cinema that is embraced in the region. It also serves as a melting pot as migrants feel at home in the country. In the realm of culture, Egypt enjoys impressive soft power, exemplified by the spread of its films, music, and media across the Middle East. It accounts for a significant Arab audience in terms of TV time and more than three-quarters of Arab countries' films, resulting in Cairo and Alexandria hosting international film festivals and enhancing the profile of Egyptian artists as the most followed in the region (Youssef, 2017). Egypt's film industry emerged in the 1920 s through the works of the pioneer of Egyptian cinema, Mohammed Bayoumi, who studied cinema in Germany and returned to Egypt in 1923 to shoot the first Egyptian movie, In the Land of Tutankhamun. The industry has since grown to dominate the MENA region. The 1940s and 1950s are often referred to as the golden age of Egyptian cinema as the industry produced more than 100 movies annually that were well received across the Arab World (Fanack, 2012). Indeed, Egyptian films dominate the Arab world, with Arabs glued to their screens to watch Egyptian soap operas, comedy, music, and talk shows (Youssef, 2017). It is against this backdrop that the Egyptian film industry is often dubbed the Hollywood of the Arab World. Thanks to the country's entertainment industry, many Arabs understand the Egyptian dialect and colloquialisms and often mimic what they hear in Egyptian movies, music, and programmes (Mason, 2016). Egyptian film artists' success has been critical in counteracting negative stereotypes of the country, the Arab world, and Africa.

Los Angeles-born Egyptian actor Rami Malek has used his role in Hollywood movies and series such as Mr. Robot, Night at the Museum, The Pacific, and Bohemian Rhapsody, and his various awards including a Golden Globe, Bafta, Emmy, and Oscar, to put the Arab world on the global map in terms of entertainment. He was the first Arab actor to win an Academy Award (Sharma, 2020). Like Mohammed Salah, Malek featured in Time Magazine's 100 Most Influential People in 2019. The publication noted: "He developed the skill without which his many attributes as an artist might have been squelched - principled leadership. He's understated and kind, complicated and relatable; he's downright mercurial. Crucially, he's a good man evolving alongside his potential" (Time, 2019). Another Egyptian-American actor, Ramy Youssef, started his acceptance speech with "Allahu Akbar" after winning the 2020 Golden Globe award for best actor in a TV musical or comedy, defeating heavyweights such as Michael Douglas, Paul Rudd, Bill Hader, and Ben Platt (Sharma, 2020). His popular series titled Ramy depicts an Egyptian Muslim family in New Jersey confronted by a myriad of social issues that resonate with Arabs across the world including family life, religious prejudice, and identity in the United States.

Rami Malek and Ramy Youssef are thus also well placed to reduce levels of Islamophobia and anti-Arab sentiment across the globe. In the words of Cairoborn Hollywood actor Mena Massoud, who is probably best known for his role in the 2019 film Aladdin, "I'm trying to be a voice for the North African Arab community. We've got to continue to fight for our place in the industry" (Sharma, 2020: para. 4). 


\section{Egypt}

Returning to the local scene, the Egyptian film industry has popularised many movie stars, including veterans such as Nabila Ebeid, Nadia al-Gondi, Adel Imam Ahmed Zaki, Mahmoud Abdel Aziz, and Yousra (Fanack, 2012). However, the Egyptian government's crackdown on production companies, film makers, and artists such as Hossam Eddin el-Meneai has been a major impediment. A documentary filmmaker, el-Meneai, was arrested in 2014, ostensibly for spreading rumours about the military government, and Aalam Wassef was arrested for similar reasons (Aljazeera, 2016). Despite continuous dominance in the Arab world, the Egyptian film industry has declined, which is evident in the list of the top 100 Arabic films put together by the Dubai International Film Festival (DIFF) in 2013. While Egyptian movies scooped 35 places from the 1940 s to the $1960 \mathrm{~s}$, dominating the list, only three made the list from the $1990 \mathrm{~s}$ onwards (Aly, 2016). This is partly due to the emergence of other film centres in countries such as Syria, Algeria, Kuwait, and, more recently, Lebanon.

The tendency of many producers to be solely driven by the profit motive versus the industry's and, by extension, Egypt's image, and excessive representation of Egyptian men as thugs and women as sex objects pose another challenge (Aly, 2016). Government censorship of movie content and smaller production budgets have also contributed to the decline of the Egyptian film industry. In the words of Aly Mourad, CEO of Al Shorouk for Media Productions, "I don't think we've heard of this level of censorship since the time of [former President] Nasser; it's like we are going back 60 years in time" (El Banhawy, 2019: para. 4). This has significantly reduced film production and inhibited producers' freedom to make movies that highlight social ills and project Egypt's soft power in the Arab world.

In 2017, the Egyptian government established institutions to ostensibly reform the media industry. However, this seems to be another form of censorship as content published or broadcast that is deemed "harmful to national security" is punishable under the law including fines, travel bans, and possible imprisonment (El Banhawy, 2019: para. 8). A 2018 film titled Karma was banned (although the decision was subsequently revoked) and several film makers have been fined and banned from travelling, prompting Human Rights Watch to describe this as a "campaign to crush artistic freedom" (Human Rights Watch, 2018). This has resulted in films as propaganda, as producers produce content against their will such as portraying the military and police in a positive light in order to avoid the risk of their films being banned.

It is worth noting that the works of Egyptian literary icons such as Tawfik El Hakim, Taha Hussein, and Naguib Mahfouz are extremely popular in other Arab states (Tadros, 2017). Egypt prides itself on being home to the only Arab writer - Naguib Mahfouz - to have won the Nobel Prize in Literature (Sayed, 2017). These writers' influence radiates across the Arab world. They have taken advantage of the common Arabic language to spread their ideas and by extension Egypt's culture. On many levels, Egypt has acted as a trailblazer, demonstrated by its many firsts in its region: the first modern army, the first modern universities, the first school of medicine, and the first school of engineering. 
However, while Cairo has long been the hub of Arab culture, in recent times it has been increasingly challenged by Turkey and Iran.

\section{Membership of international organisations and diplomatic engagements}

Egypt is a major contributor to UN peacekeeping operations, prompting UN Secretary General António Guterres to assert in 2017 that it is a "pillar of multilateralism in today's world" (Leijenaar, 2017: para. 1). Egypt has shown its commitment to the promotion of peace in Africa, the Middle East, Asia, and Latin America. This positions Cairo as a global peacemaker, reinforcing its soft power. Egypt made its first contribution to the UN peacekeeping mission in the Congo in 1960; and by 2015 Cairo had deployed more than 30,000 troops to 37 UN peacekeeping missions in 24 countries in Africa, Asia, Europe, and Latin America (Leijenaar, 2017) and contributed to peace missions such as the AU-UN Hybrid Operation in Darfur (UNAMID), the United Nations Organization Stabilization Mission in the Democratic Republic of the Congo (MONUSCO), the United Nations Mission in South Sudan (UNMISS), the United Nations Multidimensional Integrated Stabilization Mission in Mali (MINUSMA), the United Nations Mission in Liberia (UNMIL), the United Nations Assistance Mission for Iraq (UNAMI), the United Nations Operation in Côte d'Ivoire (UNOCI), the United Nations Mission for the Referendum in Western Sahara (MINURSO), and the United Nations Stabilization Mission in Haiti (MINUSTAH). This is intertwined with the North African country's peacebuilding efforts across these conflict zones. Table 5.3 lists the top ten troop contributors to the UN.

As Table 5.3 reveals, Cairo is the third largest troop contributor to UN peacekeeping operations. It is against this backdrop that Egypt became a non-permanent member of the UN Security Council between 2016 and 2017, having previously

Table 5.3 Top ten troop contributors to the United Nations

\begin{tabular}{cll}
\hline Rank & Country & Number of troops \\
\hline 1 & Rwanda & 1,115 \\
2 & Senegal & 1,102 \\
3 & Egypt & 975 \\
4 & Bangladesh & 793 \\
5 & Nepal & 699 \\
6 & Togo & 522 \\
7 & Ghana & 472 \\
8 & Jordan & 426 \\
9 & Burkina Faso & 382 \\
10 & Indonesia & 381 \\
\hline
\end{tabular}

Source: author's adaptation from the UN website. https://peacekeeping.un.org/en/troop-and-p olice-contributors. 
served in 1946, 1949-1950, 1961-1962, 1984-1985, and 1996-1997, presenting an opportunity for the country to represent the interests of African and Arab states. This provides a soft power reservoir and a launch pad for Cairo to compete for a permanent seat on the UN Security Council, should the Council be reformed. During its presidency of the Council in May 2016, Egypt pushed for effective collaboration between the UN and the AU, particularly in the areas of conflict prevention, peacemaking, peacekeeping, and peacebuilding; and engaged the question of sustainable financing to enable the implementation of the objectives of the African Peace and Security Architecture (APSA) and Post-Conflict Reconstruction and Development (PCRD) (Leijenaar, 2017). Egypt further urged the UN to fight terrorism in Africa, the Middle East, and globally (Leijenaar, 2017).

During its chairpersonship of the AU Peace and Security Council (PSG) in September 2016, Cairo led the discussion between the UNSC and the AU PSC and has also been instrumental in bringing sub-Saharan Africa and North Africa together (Leijenaar, 2017). In 2018, during a plenary session of the UN General Assembly on equitable representation in the Security Council, Egypt argued for the allocation of two permanent seats and five non-permanent seats to Africa in a reformed Security Council (Al-Youm, 2018) as envisaged by the African position reflected in the Ezulwini Consensus and the Sirte Declaration. When the mandate of the mission in the Central African Republic (MINUSCA) was up for renewal in 2017, Egypt ensured that the phrase "lack of effective command and control, refusal to obey orders, failure to or respond to attacks on civilians", which the North African country felt would be unfair to states contributing troops, was removed from the text (Riveria, 2018: para. 15). In addition, alongside states such as China and Russia, Egypt opposed a US-supported arms embargo on South Sudan (Rivera, 2018). This multilateral diplomacy illustrates Egypt's capacity (derived from its power of attraction) to determine issues of regional and global consequence.

Cairo has worked vigorously to combat international terrorism and played a leading role in the adoption of 11 counter-terrorism resolutions that address issues such as judicial cooperation, human trafficking, and financing terrorism (Rivera, 2018). Many UN regional offices such as the Office for the Coordination of Humanitarian Affairs (OCHA), UN Women, UN Development Programme (UNDP), World Health Organisation (WHO), the United Nations Educational, Scientific and Cultural Organisation (UNESCO), World Food Programme (WFP), UN High Commission for Refugees (UNHCR), UN Office on Drugs and Crime (UNODC), and UN Population Fund (UNFPA) are located in Egypt. Cairo's embrace of multilateralism as opposed to unilateralism is further captured by its role as a founding member of a number of international organisations such as the Organisation of African Unity $(\mathrm{OAU})$, now the AU, the League of Arab States, the Organisation of the Islamic Conference (OIC), now Organisation of Islamic Cooperation, and the Non-Aligned Movement.

Egypt has thrown its weight behind the implementation of the African Solidarity Initiative (ASI) that aims to enhance Africa's capacity to foster development in post-conflict states, and proposed the establishment of the African Center 
for Post Conflict, Reconstruction and Development (AUCPCRD) to the AU. The country also hosts the Cairo Centre for Conflict Resolution and Peacekeeping in Africa (CCCPA), an AU training centre that offers courses to troops including the North Africa Brigade of the African Standby Force (ASF), and the African Union Mission in Somalia (AMISOM). The Centre also conducts peacekeeping training for civilians in Africa, the only centre with such responsibility in the Arab world, and the Egyptian Agency of Partnership for Development has been instrumental in the country's peacebuilding and sustainable development efforts (Leijenaar, 2017). In the aftermath of Abdel-Fattah el-Sisi's military coup in 2013, which removed the democratically elected government of Mohammed Morsi, Egypt was suspended from the AU. However, the ban was lifted a year later and el-Sisi chaired the AU in 2019. During his time in office the African Continental Free Trade Area (AfCFTA) came into force after it was ratified by 22 states (DW, 2020). The chairpersonship also helped Egypt to strengthen its relations with other African states that suffered after the 2013 coup d'état. It is thus clear that Egypt has augmented its soft power through its engagement in different multilateral platforms.

Since his emergence as President in 2014, el-Sisi has established and maintained cordial relations with key world leaders including US President Donald Trump, Chinese President Xi Jinping, and Russian leader Vladimir Putin. The benefits of these personal relationships have translated to Egypt's emergence as the third largest importer of weapons (France 24, 2020). Egypt has also broadened its relations with key states in the Gulf, Israel, France, and Italy. In this period of COVID-19, el-Sisi's administration has engaged in health diplomacy by sending medical aid to some of the most affected countries including China, the United States, Italy, and the UK, including offering the United States 200,000 masks, 48,000 shoe covers, and 20,000 surgical caps (France 24, 2020). Although Egypt is a major recipient of US aid, to the tune of around $\$ 1.3$ billion annually (France 24, 2020), this gesture is questionable in light of its fragile health system which has struggled to fight the pandemic at home.

Cairo's diplomacy has clearly taken a knock in light of its apparent bystander role in major incidents in the Middle East including the occupation of Iraq, the rise of Turkey and Iran, the Israel-Lebanon war, and the Palestinian-Israeli conflict, among others (Hamzawy, 2010). This has punctured Egypt's voice and influence in regional affairs. The influence Egypt enjoyed in Africa from the time of the Nasser administration to the 1980s has declined significantly given the fact that Cairo has prioritised its relations with the Arab countries and the West rather than Africa (Hamzawy, 2010). This is complicated by perceptions of Egypt as an Arab state rather than an African country in sub-Saharan Africa.

While Egypt's influence has declined in the international arena, as noted earlier, el-Sisi's administration has managed to ignite relations with key states and become assertive in some important issues. Like Moscow, Paris, and Abu Dhabi, in Libya, Cairo has thrown its weight behind Khalifa Haftar and the Libyan National Army (LNA) movement (as opposed to the UN-backed Government of National Accord), which until recently controlled most of eastern Libya and aims 
to control the entire country (Sharp, 2020). Cairo's interests in Libya are twofold. The first is political stability in a state in its sub-region, while the second is the return of thousands of Egyptian workers working in Libya's energy sector prior to the Arab Spring (Sharp, 2020). In light of Turkey's apparent increased influence in the conflict, President el-Sisi noted: "we will not allow anyone to control Libya ... it is a matter of Egyptian national security" (Sharp, 2020: 15). Egypt has thus participated actively in international efforts, such as the 2020 Berlin Conference, to bring the conflict to an end and unify the country.

Given Cairo's remarkable person power, the Arab League, a forum of Egypt and the Gulf Cooperation Council (GCG) states, now has a joint military force to tackle common threats. The success of the Arab League prompted President elSisi to note that there is a direct link between Egypt's national security and the security of these states (Mason, 2016). Egypt's relations with them have swung from largely Egypt-Saudi Arabia relations to an Egypt-Qatar alliance during Morsi's administration, and Egypt-Saudi Arabia/Kuwait/UAE relations during el-Sisi's regime (Mason, 2016). While Qatar accounts for a significant number of Egyptians working in the GCC states, conflicts exist between these countries around Qatar's support for the Egyptian Muslim Brotherhood and the Al Fazeera news channel (Mason, 2016). The GCC states provide aid to Egypt to finance various projects and the latter's central bank; however, FDI that could create jobs and enhance knowledge transfer remains relatively low (Mason, 2016).

Since 2014, Cairo has strengthened its relations with Moscow, mainly in the area of arms deals that include the purchase of 46 standard Ka-52 Russian attack helicopters, and S-300VM surface to air missile defence systems, among others (Sharp, 2020). In 2015, Egypt reached a deal with Russian firm Rosatom to construct a 4,800-megawatt nuclear power plant in the North African country (Sharp, 2020). Russia has since offered to lend Egypt $\$ 25$ billion (85 per cent of the project's total costs) over 35 years for the construction of the plant (Sharp, 2020).

Following the emergence of el-Sisi as President, relations between Cairo and Washington soured as then US President Barack Obama could not turn a blind eye to human rights abuses in Egypt. The emergence of President Donald Trump heralded renewed relations between the two countries and Cairo has been commended for its fight against terrorism, economic reforms, and religious tolerance (Sharp, 2020). Beyond military relations, Egypt has sought to boost its trade relations with the United States. It currently exports apparel, natural gas, oil, and agricultural products to the United States and imports wheat, corn, machinery, aircraft, and iron and steel from it (Sharp, 2020). It is clear that, beyond its role in multilateral institutions, Egypt values its bilateral relations with key states that recognise Cairo's relevance to their economic and strategic interests.

\section{The decline of Egypt's soft power}

In the post-Arab Spring era, Egypt has witnessed a significant decline in its soft power and overall capacity to determine the behaviour of its neighbours. Its 
status has waned both in Africa and at the global level. This stems from political instability and the economic challenges confronting the country. It is complicated by the fact that, in many respects, sub-Saharan African countries tend to believe that their North African brothers often perceive themselves as more Arab than African, with corresponding effects on their interests. Economic challenges have resulted in many Egyptians seeking greener pastures in other countries. If this situation persists, Egypt might lose its best minds to other countries causing brain drain, and the loss of such individuals' potential contributions to its soft power.

\section{Political instability and human rights abuses}

The overthrow of Hosni Mubarak following the 2011 Arab Spring promised to put Egypt on the path of democracy and good governance. However, Cairo experienced political instability after this period, undermining its soft power profile and the state's ability to determine issues of regional consequence. The ousting of Mubarak ushered in the first (and only) democratically elected administration of President Mohamed Morsi in 2012. However, it had barely settled in when the President was overthrown by a military coup in 2013. Among other factors, Morsi's policy of Ikhwanization (imposition of the ideology of the Muslim Brotherhood) of the state and lack of popularity among Egyptians following disappointment at the absence of the expected dividends of democracy, contributed to the fall of his regime (Hove and Ndawana, 2017). Furthermore, the military hegemony in Egyptian politics dictates that a sustainable regime has to be amenable to the positions of the military, which Morsi was not completely open to. The military coup that toppled Morsi was wrapped in the garb of legitimacy with the election of Abdel Fattah el-Sisi as president in 2014, after winning 97 per cent of the votes (Blaydes, 2019). The 2019 protests in Egypt, ignited by allegations of political corruption and economic austerity under the auspices of the International Monetary Fund (IMF) that granted the country a $\$ 12$ billion loan, underscored the political and economic challenges confronting the current administration and the potential of political instability (Reuters, 2019). Hundreds of Egyptians took to the streets highlighting government corruption and demanding that el-Sisi step down.

Mohamed Morsi's sudden death during his trial in June 2019, military supremacy, el-Sisi's strongman politics, and the attendant repression have all contributed to Egypt's fragile stability (Melcangi and Dentice, 2019). While the 2019 constitutional referendum granted el-Sisi the opportunity to remain in office until 2030, it remains to be seen if these seeds of instability, especially police, military, and legislative repression, will disrupt his tenure. Since his election in 2014, el-Sisi has crushed all opposition, created a cabal of loyalists in the military, and appointed same to strategic positions in government (Melcangi and Dentice, 2019). He also appointed his sons to key positions in state security agencies, and by 2019 around 60,000 political opponents, critics, and members of the Muslim Brotherhood were in jail awaiting hearings, with close to 2,000 individuals sentenced to death between 2014 and 2019 (Melcangi and Dentice, 2019). In 
justifying his repressive approach, el-Sisi often emphasises the imperative to guarantee political stability, prevent the crisis that characterised the postMubarak era, and avoid the realities of other Arab states in conflicts such as Libya, Yemen, and Syria (Blaydes, 2019). Autocratic rule is a critical soft power deficit as the country has no moral basis to preach for democracy and good governance in the region. This is arguably an edge enjoyed by Ankara over Cairo in the MENA region.

Wilayat Sinai, which mainly operates in the Sinai Peninsula, emerged as a militant group in 2011 following the overthrow of Hosni Mubarak and pledged allegiance to the Islamic State in Iraq and Syria (ISIS) in 2014. This group poses a significant challenge to Egypt's stability. Wilayat Sinai has claimed responsibility for attacks on churches, mosques, the Egyptian military, and government sites, as well as the Russian airplane in 2015 that resulted in the death of all 224 people on board (Council on Foreign Relations, 2020). The bombing of a cathedral in 2018 resulted in the cancellation of around 40 per cent of hotel reservations for tourists from Arab, East Asian, and European countries (Fanack, 2020). In response to this campaign of terror, in February 2018, el-Sisi ordered the country's military to crush the group. By February 2019, the military stated that it had killed more than 550 members; however, the group remains potent.

Egypt's record on human rights and democratisation has been subject to criticism even among its closest allies such as the United States. However, Cairo has often argued that these are domestic issues that do not justify external interference. For example, the Mubarak administration often told the United States - each time the latter suggested reforms - that democratisation would result in the Muslim Brotherhood ascending to power (Chomsky and Achcar, 2007). Among other things, Egyptians' access to the Internet is restricted and their private online communications are monitored by the government (Sharp, 2020). el-Sisi implemented a media regulatory framework that established government-controlled supervisory bodies that can determine the content and licences of the media (Ghafar, 2018). Following the 2018 amendments to the Media and Press Law, the Supreme Media Council was granted the authority to suspend a social media account with 5,000 and more followers, if such account promotes false news or violence (Sharp, 2020). In 2019, 34,000 websites were blocked prior to a referendum on amendments to the country's 2014 constitution that could extend el-Sisi's term to 2030 (El Banhawy, 2019). Similarly, in 2019, the government required public transport companies such as Uber to submit customers' data in the previous six months to the Ministry of Transportation (Sharp, 2020) and President Abdel Fattah el-Sisi has often embarked on crackdowns against political opponents and vocal critics of his administration, labelling opponents as terrorists and agents of foreign governments and using this as an ideological cover to detain and jail former President Morsi and some Muslim Brotherhood leaders. Other local critics of the regime such as Mohamed ElBaradei, former Director General of the International Atomic Energy Agency, have also been targeted (Nakhleh, 2013). These are but a few examples of how Egyptians' rights and privacy are being violated, redounding to negative perceptions of Egypt in the international system. 


\section{Economic challenges}

Egypt has also been bedevilled by a growing population, high levels of unemployment, and energy shortfalls. The levels of unemployment are perhaps best demonstrated by the role played by the youth during the Arab Spring (Hove and Ndawana, 2017). With a population of around 100 million, Egypt has struggled to provide social services for its teeming population. The UN forecasts that it will be home to 150 million people by 2050, and 200 million by 2100 (Ghafar, 2018). In a country where 32.5 per cent of citizens were living below the poverty line in the 2017/2018 financial year (Reuters, 2019), there is bound to be discontent. The Egyptian government has put some measures in place to stabilise the economy including fiscal consolidation, liberalisation of the exchange rate, and energy sector reforms, which have enhanced growth, reduced the debt-to-GDP ratio, and boosted foreign reserves (World Bank, 2020). Real GDP growth was 5.6 per cent in the 2019 fiscal year, up from 4.6 per cent from the previous three years; however, at 39 per cent (World Bank, 2020), unemployment remains very high, generating anger, especially among the youth. This is complicated by the increasing poverty rate, which jumped from 27.8 per cent in 2015 to 32.5 per cent in the 2017/2018 fiscal year (World Bank, 2020). To mitigate the levels of unemployment, the el-Sisi administration has embarked on reforms to remove impediments to economic transformation in the private sector (World Bank, 2020). However, given the anger and frustration among the youth and the fact that 61 per cent of the population under the age of 30 are job seekers (Melcangi and Dentice, 2019), if this time bomb is not properly addressed, there could be serious casualties and instability.

Various indices that measure economic performance confirm the challenges confronting Egypt's economy. The country does not fare well in: the World Bank's Governance or Ease of Doing Business indices; Transparency International's Corruption Perception Index; the Bertelsmann Foundation's Transformation Index; The Economist Intelligence Unit's Business Environment Ranking; and the Arab Reform Initiative's Democracy Index (Springborg, 2017). Given that state-market relations are determined by rent seeking, the viability of the various economic sectors is determined by their capacity to generate rent as in tourism (land activity), which generates significant rent for the military (the largest owners of land) through land transactions (Springborg, 2017).

Foreign direct investment remains weak, despite a rise of 6.5 per cent in inflows in the 2016/2017 financial year. This equated to $\$ 7.92$ billion, less than the government's target of $\$ 10$ billion (Meighan, 2017). The situation is compounded by the country's debt crisis. Aside from local debt, Egypt owes international organisations like the World Bank and IMF and the government spends more than 58 per cent of its budget to service its debt (Hamed, 2019). While Egypt has impressive foreign reserves of over $\$ 40$ billion, this is largely made up of external debt (Hamed, 2019). This has undoubtedly had a significant impact on government's domestic responsibilities (such as health, education, infrastructure, and other social amenities) let alone its international engagement. It 
undermines Egypt's capacity to exercise soft power as the limited government funds are mainly spent on domestic imperatives at the expense of the country's international activities.

Following the 2011 revolution in Egypt, the tourism industry suffered until 2017. For example, the number of tourists declined by 34.7 per cent and there was a 47.9 per cent decline in tourism revenue in the 2014/2015 financial year (Fanack, 2020). In June 2016, the number of tourists dropped by 41.9 per cent in comparison with the 2015 figure, and in 2017 the number of Russian, British, and German tourists dropped by 60 per cent, 17.5 per cent, and 10.4 per cent, respectively, prompting tourist sites and hotels to lay off 720,000 of 800,000 workers (Fanack, 2020). However, in 2018 Egypt recorded 11.3 million tourists, the largest number since 2012 (Melcangi and Dentice, 2019). Given that the country earned $\$ 11.6$ billion from tourism in the 2009/2010 financial year, it remains to be seen if it will be able to maintain this momentum and achieve the figures recorded prior to the 2011 revolution.

In an attempt to address economic underperformance, in 2016 the Egyptian government implemented a three-year economic reform programme supported by the IMF Extended Fund Facility to the tune of $\$ 12$ billion. Among others, it aimed to make interventions in: fiscal, monetary, and exchange rate policies; energy subsidies; government finances; the energy sector; privatisation; infrastructure; and the investment climate with the ultimate objective of restoring macroeconomic stability, reducing the budget deficit and public debt, promoting inclusive growth, creating jobs, correcting external imbalances, and restoring competitiveness (El Safty, 2020). While the programme, which ended in 2019 , yielded positive results in the areas of domestic absorption and macroeconomic indicators such as GDP growth, a number of challenges remain, especially as regards sustainable and inclusive economic growth, domestic investment, and FDI (El Safty, 2020). The government thus needs to do more in tackling the challenges that have undermined Egypt's economic performance, undercut its soft power, and constrained the country from acting as an effective hegemon in Africa and the Middle East.

The government also needs to tackle poverty as around 60 per cent of the population is either poor or vulnerable, resulting in high levels of inequality (World Bank, 2019c). In 2019, the national statistics agency noted that 33 per cent of the population was poor and the el-Sisi administration has fixed the official poverty line at just 736 pounds $(\$ 45)$, an amount which is considered low by many economic experts (The Economist, 2019). High levels of inflation between 2015 and 2017 resulted in a decline in household purchasing power (Fanack, 2020). Clearly, a poor country is incapable of effectively leading a region as the resources required to do so are lacking.

\section{Declining geo-political influence}

El-Menawy (2018: para. 15) notes: "Soft power is the most important tool of the Egyptian state in carrying out its domestic and foreign policies to defeat the 
discourse of hatred, violence and extremism, and promoting peaceful coexistence between the various fabrics of society." This is important as Egypt's decline in Middle East politics seems to have created a vacuum that is difficult to fill. Many Arabs are of the view that the challenges confronting the Arab world are amplified by Egypt's current weaknesses and believe that the success of this world is directly linked to the rise of Egypt (Nafi, 2017). However, the rise of Turkey and Iran, and Egypt's decline, have shifted the geo-political calculus of the region in favour of the former. In the face of political instability and economic challenges, Cairo has been forced to focus on domestic imperatives, thereby playing a less assertive role in international affairs. Turkey and Iran have benefitted from this void. While Cairo has long been the hub of Arab culture, in recent times Turkey and Iran seem to have been playing this role (Sayed, 2017). For example, Turkish TV series are now the second largest - behind American ones - in terms of exports, as 102 countries (especially the Arab markets) are consuming these entertaining programmes (Abdel-Wahed, 2019). While Egypt's soft power has dominated the Arab world in the past, in recent times other Arab soft power states have emerged, challenging and perhaps exercising more soft power than Cairo. For example, the United Arab Emirates (UAE) hosts satellite campuses of heavyweight universities, including New York University, Institut Européen d'Administration des Affaires (INSEAD), and the Paris-Sorbonne University, and has many tourist attractions including the Burj Khalifa (the world's tallest building) and Dubai Mall (one of the world's largest), both in Dubai; and Ferrari World, the Guggenheim Museum, and the Louvre Museum in Abu Dhabi (Mason, 2016).

Qatar has satellite campuses of Georgetown University, Cornell University, HEC Paris, and Texas A\&M; and Doha's Al Fazeera rather than Egypt's Al Ahram has undoubtedly become the most important news channel in the Arab world with influence comparable to that of CNN and the BBC (Mason, 2016). Unlike Egypt, these countries have benefitted significantly from their oil revenues. This prompted Tadros (2017: para. 9) to note that:

From Syria to Yemen and even in neighboring Libya, Egypt has lost its ability to impact its surroundings. Even regional allies are growing frustrated with Egypt and its president. Those in the Gulf dreaming of Egypt becoming a counterbalance to Iran are realizing the futility of their investments. In all cases Egypt is increasingly deteriorating under the weight of its own troubles.

Egypt has also lost its status as the region's stabiliser, evident in its lesser role in the crises in Palestine, Libya, and Syria. For example, the country was not invited to a 2018 meeting in Paris on the Libyan crisis that brought the conflicting political parties to the negotiation table. Furthermore, rather than an Egyptian, a Lebanese - Ghassan Salamé - was appointed as the UN envoy to Libya. While, in the past, Egypt was able to tap its soft power resources including its well-trained diplomats to mediate, persuade, and offer solutions to conflicts in the region, it has forfeited that capacity in recent years due to its domestic circumstances. 
Cairo previously exercised significant soft power laced with hard power in the Nile, declaring upstream dam-building a legitimate reason to embark on war, if it reduces the inflow into Egypt (Grafton et al., 2014). Among other possible factors, this arguably prevented Ethiopia from building dams in the Nile. However, it has squandered its dominance in this realm thanks to Cairo's declining regional position and China's offer of assistance to states such as Sudan and Ethiopia. Following the failed round of negotiations in Sharm El-Sheikh, Egypt, five upstream states signed an agreement in 2010, disregarding Egypt's authority on the Nile and its threats (Hamzawy, 2010). After the initial threats failed, Cairo decided to downplay the significance of the agreement by noting that it is not binding. Following the adoption of the agreement by most of the countries in the Nile, Egypt had no other option but to appeal to these states to return to the negotiation table (Hamzawy, 2010). Similarly, while Egypt was wallowing in the Arab Spring in 2011, Ethiopia launched its $\$ 4.2$ billion Grand Ethiopian Renaissance Dam (GERD), a hydroelectric project, which is now near completion on the Blue Nile. This has created ongoing tension between the two countries. It is thus clear that in light of its domestic imperatives, Egypt is increasingly becoming just another state in the region.

It should be noted that President Abdel Fattah el-Sisi's administration has made conscious efforts to boost Egypt's soft power, especially in the cultural realm. For instance, the President has focused on enhancing the profile of its arts and media personalities, and writers. He has held many meetings with individuals in this sector and embarked on foreign trips with some (El-Menawy, 2018). The administration has also facilitated an annual 20 per cent increase in cultural exports, a rise in the number of cinemas and theatres, and measures of Egypt's cultural output and influence through annual indicators that include indices of cultural freedom and creative empowerment (El-Menawy, 2018). These are significant steps that could enhance the country's cultural soft power and win the hearts and minds of its wider audience, potentially strengthening its influence in the international arena.

\section{References}

Abdel-Wahed, M. (2019). "Egypt: The Importance of 'Soft Power'."22 March. http://english. ahram.org.eg/NewsContentP/44/328683/Analysis/Egypt-The-importance-of-\%E2\%80\% 98soft-power\%E2\%80\%99.aspx.

Aboul-Ela, H. (2010). "Is There an Arab (Yet) in This Field? Postcolonialism, Comparative Literature, and the Middle Eastern Horizon of Said's Discourse Analysis." Modern Fiction Studies 56 (4): 729-750.

Adamson, F. and Tsourapas, G. (2019). "Migration Diplomacy in World Politics." International Studies Perspectives 20 (2) 113-128.

Agence France-Presse. (2019). "Repression Risks Fueling Egypt Instability, Analysts Warn.” 29 September. https://www.voanews.com/africa/repression-risks-fueling-egyp t-instability-analysts-warn.

al-Dosary, S. (2018). "The Soft Power of Mohammed Salah.” Al Arabiya, 27 April. https:// english.alarabiya.net/en/views/news/middle-east/2018/04/27/The-soft-power-of-Mo hamed-Salah.html. 
Aljazeera (2016). "The Power of Egyptian Cinema - Online.” Aljazeera, 24 June. https:// www.aljazeera.com/news/2016/06/power-egyptian-cinema-online-160612084145507. html.

Alrababa'h, A., Marble, W., Mousa, S., and Siegel, A. (2019). "Can Exposure to Celebrities Reduce Prejudice? The Effect of Mohamed Salah on Islamophobic Behaviors and Attitudes." Immigration Policy Lab Working Paper No. 19-04.

Al-Youm, A. (2018). "Egypt Calls for Allocating 2 African Seats in UN Security Council." Egypt Independent, 22 November. https://egyptindependent.com/egypt-calls-for-alloca ting-2-african-seats-in-un-security-council/.

Aly, E. (2016). "Is Egypt Still the 'Hollywood of the Middle East'?" The Caravan, 25 March. https://www.auccaravan.com/?p=3571.

American Chamber of Commerce in Egypt (2019). "Egypt's Soft Power: A Force to Be Reckoned With." https://www.amcham.org.eg/publications/business-monthly/issues/ 287/November-2019/3902/egypts-soft-power-a-force-to-be-reckoned-with.

Bahgat, G. (2007). "Nuclear Proliferation: Egypt." Middle Eastern Studies 43 (3): 409-421.

Bel-Air, F. (2016). Migration Profile: Egypt. Migration Policy Centre. Florence: European University Institute.

Bird, B. (2019). "How Mohamed Salah Inspired Me to Become a Muslim." The Guardian, 3 October. https://www.theguardian.com/football/2019/oct/03/mohamed-salah-insp ired-me-become-muslim-liverpool-islam.

Blaydes, L. (2019). "Challenges to Stability in Egypt." 22 April. https://www.hoover.org/ research/challenges-stability-egypt.

Chomsky, N. and Achcar, G. (2007). Perilous Power: The Middle East and US Foreign Policy. Oxon: Routledge.

Colla, E. 2007. Egyptology, Egyptomania, Egyptian Modernity. Durham and London: Duke University Press.

Council on Foreign Relations (2020). "Instability in Egypt." https://www.cfr.org/globa l-conflict-tracker/conflict/instability-egypt.

Dawood, I. (2012). "The Engagement of Highly Skilled Egyptian Migrants in OECD Countries." The Center for Migration and Refugee Studies, American University in Cairo.

De Bel-Air, F. (2016). Migration Profile: Egypt. Florence: European University Institute.

de Haas, H. (2007). North African Migration Systems: Evolution, Transformations and Development Linkages. Oxford: International Migration Institute, University of Oxford.

DW (2020). "Egypt's President El-Sissi's One Year as Head of The African Union." 7 February. https://www.dw.com/en/egypts-president-el-sissis-one-year-as-head-of-the-a frican-union/a-52296736.

Egypt Today (2018). "Foreign Ministry Spokesman Congratulates Mohamed Salah." Egypt Today, 23 April. https://www.egypttoday.com/Article/8/48460/Foreign-Ministry-sp okesman-congratulates-Mohamed-Salah.

El Banhawy, Y. (2019). "Why Is the Egyptian State Monopolizing the Entertainment Industry?"24 June. https://www.opendemocracy.net/en/north-africa-west-asia/why-e gyptian-state-monopolizing-entertainment-industry/.

El-Mahdi, R. (2009). "Enough! Egypt's Quest for Democracy." Comparative Political Studies 42 (8): 1011-1039.

El-Menawy, A. (2018). "Egypt Determined to Use Culture to Restore Its Soft Power." The Daily Observer. 5 July. http://www.observerbd.com/details.php?id=146213.

El Rehim, A. (2017). "The Potential of Egypt's Soft Power Post Arab Spring." Geopolitics under Globalization 1 (1): 12-16. 
El Safty, A. (2020). "Egypt Beyond Economic Stabilization: The Road to Sustainable Growth." 10 March. http://trendsresearch.org/insight/chep-framework-and-the-cha llenges-facing-egyptian-economy/.

ElSebaie, R. and Mouawad, A. (2014). EU and Egypt 30th of June Revolts: A Normative Power Lens. Final Search Academic Conference: "How to Strengthen EU-NGs Relationships." Barcelona, 10-11 February 2014.

Fanack (2012). "Egyptian Films." 12 November. https://fanack.com/egypt/society-media -culture/culture/film/.

Fanack (2020). "Economy of Egypt." https://fanack.com/egypt/economy/.

France 24 (2020). "Egypt Leverages 'Soft Power' Through Medical Aid in Pandemic." 14 May. https://www.france24.com/en/20200514-egypt-leverages-soft-power-through-m edical-aid-in-pandemic.

Ghafar, A. (2018). "Egypt's Long-term Stability and the Role of the European Union." 1 March. https://www.brookings.edu/blog/order-from-chaos/2018/03/01/egypts-longterm-stability-and-the-role-of-the-european-union/.

Global Fire Power (2020). "2020 Military Strength Ranking." https://www.globalfirep ower.com/.

Grafton, R., Wyrwoll, P., White, G., and Allendes, D. (2014). Global Water: Issues and Insights. Canberra: ANU Press, The Australian National University.

Hamed, Y. (2019). "Egypt's Economy Isn’t Booming. It's Collapsing." Foreign Policy 7 June. https://foreignpolicy.com/2019/06/07/egypts-economy-isnt-booming-its-collapsing-im f-abdel-fattah-sisi-poverty/.

Hamzawy, A. (2010). "The Nile in Crisis: The End of Egypt's Soft Power." Carnegie Endowment for International Peace 28 May. https://carnegieendowment.org/2010/05/28/ nile-in-crisis-end-of-egypt-s-soft-power-pub-40938.

Hinnebusch, R. (2013). "Failed Regional Hegemons: The Case of the Middle East's Regional Powers." Fournal of Diplomacy \& International Relations 14 (11): 75-88.

Hove, M. and Ndawana, E. (2017). "Regime-Change Agenda: The Egyptian Experience from 2011 to 2015." Contemporary Arab Affairs 10 (1): 32-50.

Human Rights Watch (2018). "Egypt: Campaign to Crush Artistic Freedom.” 16 August. https://www.hrw.org/news/2018/08/16/egypt-campaign-crush-artistic-freedom.

International Organisation for Migration (2010). A Study on the Dynamics of the Egyptian Diaspora: Strengthening Development Linkages. Cairo: International Organization for Migration.

Lietzelman, H. (2014-2015). "Pharaonism: Decolonizing Historical Identity." Prized Writing 2014-2015: 46-51.

Leijenaar, A. (2017). "Egypt Renews Its Commitment to Africa: Egypt's Stake in Africa's Peace, Security and Development Is Often Overlooked." 20 March. ISS Today.

Mason, R. (2016). "Egypt's Future: Status Quo, Incremental Growth or Regional Leadership?" Middle East Policy XXIII (2): 76-94.

Meighan, B. (2017). "Egypt's Foreign Reserves Have Begun to Recover, But Weak Foreign Direct Investment and Accumulating Debt Could Hinder Reforms Down the Line." 5 December. https://carnegieendowment.org/sada/74920.

Melcangi, A. and Dentice, G. (2019). "Challenges for Egypt's Fragile Stability." https:// www.atlanticcouncil.org/blogs/menasource/challenges-for-egypt-s-fragile-stability/.

Miccoli, D. (2012). "Moses and Faruq. The Jews and the Study of History in Interwar Egypt 1920s-1940s." Quest: Issues in Contemporary Fewish History 4.

Mohamed, H. (2019). "Egypt's Sisi Takes Over as New Head of African Union." Aljazeer 10 February. https://www.aljazeera.com/news/2019/02/egypt-sisi-takes-head-africa n-union-190210140131428.html. 
Monier, E. (2014). "The Arabness of Middle East Regionalism: The Arab Spring and Competition for Discursive Hegemony between Egypt, Iran and Turkey." Contemporary Politics 20 (4): 421-434.

Nafi, B. (2017). "Middle East Eye." 16 May. http://www.middleeasteye.net/columns/ egypt-no-longer-heart-arab-world-1843971737.

Nakhleh, E. (2013). "Propaganda and Power in the Middle East." Current History 122 (758): $356-363$.

News24 (2013). "Egypt: Understanding the Political Instability." https://www.news24. com/news24/mynews24/Egypt-Understanding-the-political-instability-20130816.

Nosseir, M. (2018). "Why Egypt's Soft Power has Dwindled Away." Arab News. July 24. http://www.arabnews.com/node/1156951.

Reuters (2019). "Egypt on Edge after First anti-Sisi Protest for Years." 25 September. http s://www.reuters.com/article/us-egypt-protests/egypt-on-edge-after-first-anti-sisi-protest -for-years-idUSKBN1WA1Y3.

Riggs, C. (2013). "Colonial Visions: Egyptian Antiquities and Contested Histories in the Cairo Museum." Museum Worlds: Advances in Research 1: 65-84.

Rivera, J. (2018). "An Inside View of African Diplomacy in the UN Security Council." 14 February. https://www.africaportal.org/features/inside-view-african-diplomacy-un-se curity-council/.

Rubin, L. (2010). A Typology of Soft Powers in Middle East Politics. Dubai Initiative Working Paper No. 5.

Sayed, N. (2017). "Egypt Must Reclaim Soft Power Keys in the Region: Analysis." Egypt Today July 24. https://www.egypttoday.com/Article/2/13562/Egypt-must-reclaim -soft-power-keys-in-the-region-analysis.

Sharma, K. (2020). "The Egyptian Actors Shattering Hollywood's Stereotypes of the Arab World." Vogue, 12 May. https://man.vogue.me/entertainment/egyptian-actors-hollywood/.

Sharp, J. (2020). Egypt: Background and U.S. Relations. Washington, DC: Congressional Research Service.

Springborg, R. (2017). "Egypt's Economic Transition: Challenges and Prospects." International Development Policy 7.

Super Sport (2018). "Everyone Wants Piece of Salah.” 1 May. https://supersport.com/ football/news/180501_Everyone_wants_piece_of_Salah.

Tadros, S. (2017). "Does Egypt Still Matter?"15 March. https://www.hoover.org/resea rch/does-egypt-still-matter.

The Economist (2019). "Egypt Is Reforming Its Economy, But Poverty Is Rising." 8 August. https://www.economist.com/middle-east-and-africa/2019/08/08/egypt-is-reforming-it s-economy-but-poverty-is-rising.

Time (2019). "Time 100: Mohammed Salah." https://time.com/collection/100-most-in fluential-people-2019/5567841/mohamed-salah/.

Time Magazine (2019). “Time 100 Most Influential People 2019.” https://time.com/col lection/100-most-influential-people-2019/.

Tsourapas, G. (2018a). "Authoritarian Emigration States: Soft Power and Cross-border Mobility in the Middle East." International Political Science Review 39 (3): 400-416.

Tsourapas, G. (2018b). "Egypt: Migration and Diaspora Politics in an Emerging Transit Country." https://www.migrationpolicy.org/article/egypt-migration-and-diaspora-poli tics-emerging-transit-country.

Whiting, K. (2019). "How Mo Salah May Have Reduced Islamophobia in Liverpool." 12 June. https://www.weforum.org/agenda/2019/06/how-mo-salah-might-have-reducedislamophobia-in-liverpool/. 
Wood, M. (1998). "The Use of the Pharaonic Past in Modern Egyptian Nationalism." Journal of the American Research Center in Egypt 35: 179-196.

World Bank (2019a). World Development Indicators. Washington DC: World Bank.

World Bank (2019b). Migration and Remittances: Recent Developments and Outlook. New York: World Bank.

World Bank (2019c). "World Bank Group to Extend Current Strategy in Egypt to Maintain Momentum on Reforms." 30 April. https://www.worldbank.org/en/news/p ress-release/2019/04/30/world-bank-group-to-extend-current-strategy-in-egypt-to-ma intain-momentum-on-reforms.

World Bank (2020). "The World Bank in Egypt." https://www.worldbank.org/en/coun try/egypt/overview.

World Travel and Tourism Council (2020). Travel and Tourism: Global Economic Impact and Trend 2020. London: World Travel Tourism Council.

Youssef, D. (2017). "Egypt's Soft Power in the Arab World." Washington Examiner, 12 April. https://www.washingtonexaminer.com/egypts-soft-power-in-the-arab-world.

Zohry, A. (2013). "Egypt's International Migration after the Revolution: Is There Any Change?" Confluences Méditerranéen 87: 47-54.

Zohry, A. (2014). "Migration and Development in Egypt." In: Bommes, M., Fassmann, H., and Sievers, W. (eds), Migration from the Middle East and North Africa to Europe: Past Developments, Current Status and Future Potentials. Amsterdam: Amsterdam University Press. 


\section{Kenya \\ Harambee attraction}

\section{Introduction}

When measured by Gross Domestic Product (GDP) and military capacity, Kenya seems to lack the hard power capacity to compete with regional powers such as Nigeria, South Africa, Egypt, Algeria, Angola, and Morocco. The East African state is the seventh largest economy in Africa (World Bank, 2019), one place above its East African counterpart, Ethiopia, and ranks twelfth with respect to military power (Global Fire Power, 2020). Furthermore, Kenya has often avoided military confrontation in its sub-region, leading observers to describe the state as a reluctant power. Nonetheless, alongside Ethiopia and Tanzania, Kenya remains one of the contenders to become a hegemon in East Africa and wields considerable influence on the continent at large. This begs the question of where Kenya's sources of power can be located, given that its weak material base does not correspond with its influence in Africa. The gravitas to Nairobi's regional influence is located in its soft power, which includes: its cultural exports exemplified by its fashion industry, success in athletics, and tourism; its Harambee philosophy; and its peace diplomacy, multilateralism, and non-aggressive foreign policy.

Despite these resources, Kenya has not been able to fully realise its potential on the continent as a result of a number of challenges, including the tussle between the state and the International Criminal Court (ICG), pervasive electoral violence, and ethnic politics, as well as the endemic corruption that has damaged Kenya's image in the international arena. Nevertheless, Nairobi remains a significant actor in East Africa and regionally and could become more powerful if the impediments to its capacity to act as an effective as opposed to a reluctant power are confronted.

\section{Kenya's soft power currencies}

\section{Fashion industry, sport diplomacy, and tourism}

\section{Fashion industry}

Kenya strives to project itself in the international arena through its popular cultural items such as: Kiondo, a handwoven handbag; Kanga, a fabric that women

DOI: $10.4324 / 9781003176022-6$ 
wrap around their skirts; and a fabric for men called kiko (Njiru, 2016). Some of these cultural prints have Kenyan proverbs inscribed on them. Thus, Kenya not only accrues economic gains from the sale of these products but also promotes its culture among the international admirers of the items. The country engages in all the facets of the cotton-textile chain including cotton and lint production, yarn and textiles, and clothing production. Cotton, textiles, and apparel is the second largest industry in Kenya, pooling the skills of researchers, farmers, ginners, spinners, and other service providers (International Trade Centre, 2016). While the industry declined following trade liberalisation in the 1990s as it could not compete with cheap products imported from Asia, the launch of the African Growth and Opportunity Act (AGOA) in 2000 - a trade agreement between the United States and sub-Saharan Africa, which guarantees duty-free access to US markets - has provided the needed fillip, resulting in Kenya usurping Lesotho as the largest supplier of garments to the United States. The value of its apparel exports to the United States increased from $\$ 195$ million in 2010 to $\$ 379$ million in 2014 (International Trade Centre, 2016). The European Union is also becoming an important destination for Kenyan apparel.

"Made in Kenya" goods are now visible in key US chain stores and boutiques and to a lesser extent in places like Canada and the Netherlands (The Kenyan Textile and Fashion Industry Report, 2016). The appeal of these fabrics has led to the emergence of popular Kenyan fashion designers that appear to have taken full advantage of what the fabric represents to establish regional and possibly global brands. These include designers such as Sally Karago, Ann McCreath, Patricia Mbela, Vaishali Morjaria, John Kaveke, and Jamil Walji as well as their brands including Mcensal Fashion House, KikoRomeo, Poisa, Vaishali Creations, Kaveke, and JW Couture, respectively. Some of these designers have exhibited their brands at New York Fashion Week, cementing their place in the global fashion industry.

\section{Athletes and sport diplomacy}

The impact of Kenyan athletes in global tournaments is also worthy of note. This success story has undoubtedly drawn global attention to the East African power. It is a truism that the most successful states in sporting activities are also the most powerful states in the international arena, evident in how states such as the United States, China, the UK, and Germany have dominated global sporting events and consequently enhanced their global visibility. Kenyan athletes' success and the attendant waving of the country's flag and singing of its anthem in world tournaments draw instant global attention to the African state. The instant soft power advantage stems from the fact that Kenya is seen in another light, as an exemplary state for success in athletics other than the negative perceptions including terrorism, electoral violence, and ethnic conflicts associated with the state. It is against this backdrop that Wamanji (2016: para. 5) notes that:

As a cultural product, sports diplomacy has managed to put a sheen on the lapel of this country in the most effective way, perhaps at par with, if not 
better than, state diplomacy. Athletics has done Kenya proud in the most priceless manner.

Since the 1960s, Kenyan athletics has grown exponentially to the extent that the country has now produced more world-class athletes, Olympic medallists, and world record holders in distance running events than any other country (Singleton, 2012). Prominent Kenyan athletes include Kipchoge Keino, Tegla Laroupe, Samuel Wanjiru, Catherine Ndereba, and Paul Tergat. Tucker et al. (2015) capture Kenya's dominance thus: between 1986 and 2003, Kenyan men accounted for 13.3 per cent and 55.8 per cent, respectively, of the top 20 all-time performances in distance running events. The authors add that Kenyan men have won 43 out of 108 medals in distance running at the Olympic Games since 1990. "Today the Kenyan dominance in middle- and long-distance running is so profound that it has no equivalence to any other sport in the world" (Larsen and Sheel, 2015: 110). Table 6.1 shows the top ten medallists at the International Association of Athletics Federations (IAAF) World Athletics Championship in Doha in 2019.

With five golds, two silvers, and four bronzes, Kenya emerged second to the United States in the IAAF World Athletics Championship in 2019. In the tournament held in London in 2017, it maintained the same position with the same number of medals. In Beijing in 2015, Kenya rose to first place with seven golds, six silvers, and three bronzes. The country has indeed established itself as a formidable force, which has translated to global visibility in the arena of sport and beyond as its athletes emerged as national symbols of diplomacy in Africa and further afield. The Kenyan government has taken advantage of the success and fame of these athletes by deploying them in sports diplomacy. For instance, Tegla Leroupe was deployed as a peace envoy in the conflicts in Darfur and Northern Uganda, culminating in her appointment as the UN Ambassador of Sport in

Table 6.1 2019 IAAF top 10 medallists

\begin{tabular}{llllll}
\hline Rank & Country & Gold & Silver & Bronze & Total \\
\hline 1 & United States & 14 & 11 & 4 & 29 \\
2 & Kenya & 5 & 2 & 4 & 11 \\
3 & Jamaica & 3 & 5 & 4 & 12 \\
4 & China & 3 & 3 & 3 & 9 \\
5 & Ethiopia & 2 & 5 & 1 & 8 \\
6 & United Kingdom & 2 & 3 & 0 & 5 \\
7 & Germany & 2 & 0 & 4 & 6 \\
8 & Japan & 2 & 0 & 1 & 3 \\
9 & Uganda & 2 & 0 & 0 & 2 \\
9 & Netherlands & 2 & 0 & 0 & 2 \\
\hline
\end{tabular}

Source: World Athletics, 2019. 
2006 by then UN Secretary General, Kofi Annan (Busolo, 2016). Allison and Monnington (2005: 19) observe that:

The success of the great Kenyan athletes of the late 1960s and early 1970s certainly brought their nation a high profile that was fully exploited by their political leaders. Yet subsequent international boycotts through the 1970s and early 1980s along with the luring away to the USA of many of the outstanding Kenyan athletes on university scholarships certainly contributed to the loss of Kenyan status both in sport as well as in broader realms of international diplomacy.

The use of sports diplomacy in Kenya dates back to the colonial period. Britain encouraged Kenyan athletes to participate in the first Indian Ocean Games in Madagascar in 1952 and in the 1954 Commonwealth Games in Canada, and established the Kenyan Olympic Association in 1954, all to boost its international legitimacy and to distract local attention away from calls for independence (Byron and Chepyator-Thomson, 2015). Following independence, sports, especially athletics were critical in the process of decolonising Kenyan citizens' minds from a colonial mentality and promotion of nationalism (Byron and Chepyator-Thomson, 2015).

\section{Tourism: wildlife and landscapes}

Kenya's abundant wildlife and rich landscapes have made it one of the top tourist destinations in Africa. The country's 60 national parks and reserves offer tourists valuable cultural and historical attractions (Oxford Business Group, 2018). Many international tourists derive aesthetic pleasure from these environmental features which endear them to the African state. The Nairobi National Park, Malindi (a coastal attraction), Mount Kenya (the second highest mountain in Africa), Lamu Island (a coastal attraction), Hell's Gate National Park, Lake Nakuru, and the Masai Mara National Reserve draw thousands of tourists to Kenya each year. Kenyan cultural activities such as the Rusinga Cultural Festival, Maralal Camel Derby, Lake Turkana Cultural Festival, Mombasa International Cultural Festival, International Camel Derby Festival, Safari Rally, and Lamu Cultural Festival are also major tourist attractions.

The soft power benefits of these attractions are derived from two major factors - economic and cultural diplomacy. Travel and tourism contribute a significant share of Kenya's GDP and remain the second largest foreign exchange earner for the state. For instance, in 2017, the sector accounted for 9.7 per cent of the country's GDP and directly generated 429,500 jobs (World Travel and Tourism Council, 2018). Including jobs created indirectly the total figure stood at around 1.1 million (World Travel and Tourism Council, 2018). The tourism sector expanded by 4.9 per cent in 2019, partly due to conscious governments efforts to attract private investment and improved connectivity in the country (World Travel and Tourism Council, 2020). In 2019, Kenya welcomed 
2,048,334 tourists with 1,423,971 in Nairobi and 128,222 in Mombasa (Global Tourism Forum, 2020). Table 6.2 shows the top ten countries of origin of tourists visiting Kenya.

Table 6.2 illustrates that Kenya has been able to attract tourists from across the world from Africa to Europe, Asia, and North America with the United States topping the list. Its natural attractions as well as its unique cultural features make a meaningful contribution to the state's soft power. For instance, the Turkana cultural festival, which aims to build cultural bridges and promote national cohesion in an ethnically diversified state (Chatterjee, 2018), provides a template for international observers on how ethnic and possibly racial divides could be managed to promote national cohesion and peace, particularly in an age of populism. It is in the light of this, that the Kenyan government formulated a recovery programme that emphasises marketing, infrastructure development, and private sector investment following the slump in tourist visits consequent upon the 2011 terrorist attacks and the 2014 Ebola crisis (Oxford Business Group, 2018).

The emergence of the Ministry of Tourism in 2015 as an autonomous entity from the Ministry for East African Affairs, Commerce and Tourism also fits the context. In 1966, then Minister for Commerce and Industry, Mwai Kibaki, told the House of Representatives that "Political stability, efficient administration and progress made in building a harmonious human society in Kenya have all earned us the reputation of being one of the soundest investment prospects in independent Africa" (Howell, 1968: 45). Such confident assertions were based on the fact that Kenya accounted for significant levels of industrialisation and had emerged as the most important tourist destination in the East African sub-region, resulting in the exponential rise of its key states including Mombasa and Nairobi (Howell, 1968). Recognising the impact of Kenyan culture in Africa and beyond, the Ministry of Foreign Affairs and International Trade (2014: 19) notes that:

Table 6.2 Top ten countries of origin of tourists visiting Kenya

\begin{tabular}{cll}
\hline Rank & Country & Number \\
\hline 1 & United States & 245,437 \\
2 & Uganda & 223,010 \\
3 & Tanzania & 193,740 \\
4 & UK & 181,484 \\
5 & India & 122,649 \\
6 & China & 84,208 \\
7 & Germany & 73,1509 \\
8 & France & 54,979 \\
9 & Italy & 54,607 \\
10 & South Africa & 46,926 \\
\hline
\end{tabular}

Source: Global Tourism Forum, 2020. 
In pursuing its national interests in the international arena, Kenya continues to enjoy a favorable international profile arising from its strategic location, sustained stability, strong political institutions, sound economic policies, dynamic environmental strategies and highly educated and skilled human resources. Other positive attributes are outstanding performance by Kenya's sports persons and the increasing involvement of Kenyans abroad in national development.

\section{Harambee, cautious foreign policy, and economic diplomacy}

\section{Harambee}

Kenya's national motto, Harambee, refers to collective participation of individuals in a community to achieve set goals through pooling the community's resources (Orora and Spiegel, 1980). Harambee thus underscores community self-help and self-reliance. The Kenyan Ministry of Foreign Affairs and International Trade (2014) notes that the philosophy of Harambee is one of the key values that guides Nairobi's foreign policy. Kenya deploys Harambee philosophy in its diplomatic relations in Africa and beyond. This is evident in its economic and strategic relations, seen in the importance it places on its membership and the relevance of regional organisations such as the East African Community (EAC) in promoting collective goals. It also manifests in the state's reluctance to take a unilateral stance in its international engagements.

Nairobi plays an important role in peace processes in conflict areas like South Sudan and the Great Lakes, and Kenya is an active player in the AU Peace and Security Council (Africa Policy Institute, 2018). Arguably, the most visible area where Nairobi has deployed the Harambee philosophy is in humanitarian diplomacy. As a member of the Intergovernmental Authority on Development (IGAD), Kenya is a key player in efforts to craft and implement an African resilience framework. To this end, Kenya hosts more than 565,000 refugees including in Dadaab and Kakuma, two of the largest refugee camps in the world (Africa Policy Institute, 2018). Nairobi has participated actively in international instruments on humanitarian affairs including the 2015 Sendai Framework for Disaster Risk Reduction 2015-2030 and World Humanitarian Summit. In recognition of Kenya's role in this regard, the UN and key regional organisations often appoint Kenyan diplomats as Special Envoys in places in need of humanitarian assistance as a result of phenomena such as El Niño.

Kenya is thus well placed to promote the principle of Harambee in Africa and beyond as an alternative to the unilateral posture that characterises the realist paradigm. Ongoing efforts to combat the Coronavirus disease (COVID-19) have laid bare the critical role of Harambee community self-help systems. One of the reasons that Kenya and other African states have managed the pandemic better than other regions is that the continent understands the fragility of its health care systems and has therefore relied on community self-help systems to combat the 
virus. This reduced the spread of the disease and eased the burden on hospitals and health centres. It is testimony that the world can benefit from Kenya's philosophy of Harambee.

\section{Cautious and dovish foreign policy}

Howell (1968) observed that Kenya's international behaviour varied in accordance with the level of analysis. In its East African sub-region, Kenya adopted a cautious, conservative, and legitimist posture. On the African continent, the country assumed the role of a neutral player between the then radical and moderate states. At the global level, its foreign policy was shaped by morality and idealism, seen in its emphasis on a peaceful and just international order. Postindependence, Kenyan foreign policy was centred around three main pillars: "non-alignment, the promotion of African unity, and the eradication of colonialism" (Howell, 1968: 34). Support for the UN and its principles was also considered germane. Like most African regional powers, in contemporary times, Kenya has eschewed an aggressive and unilateral posture and favoured state sovereignty, non-interference in the internal affairs of other states, and peaceful co-existence. For instance, Kenya was not a member of the groupings of what were termed "radical", "moderate", or "conservative" states in post-independent Africa (Howell, 1968). This neutrality accorded the East African state a measure of respect and trust in its rare involvement in African diplomacy. Unlike its East African neighbours, Kenya has been immune to external aggression. The only notable exceptions in contemporary times are the activities of Somalian based alShabaab that claimed responsibility for the 2013 attacks on the Westgate shopping mall in Nairobi, the 2015 attacks on Garissa University in Garissa, and the 2019 attacks on the DusitD2 hotel and office complex in Nairobi.

Kenya's reluctance to assert itself in its sphere of influence seems bewildering, given the status it enjoys in the sub-region. It is for this reason that it is often perceived as punching below its weight in East Africa or as a reluctant regional actor (Emmanuel, 2016). It should be noted, however, that Kenya's regional powerhood is not significantly derived from hard power. In the Global Fire Power ranking, Kenya is ranked outside the top ten in Africa (Global Fire Power, 2020). Aside from the usual suspects such as Egypt, Nigeria, and South Africa, states like the DRC, Sudan, Tunisia, Ethiopia, and Morocco fare better than Kenya. In a similar vein, Kenya barely made it into the top ten in the World Bank's largest economies rankings (World Bank, 2019) with states such as Sudan and Ethiopia above it in those rankings. In this light, Kenya's influence in Africa is largely derived from its soft power gambit. Nevertheless, its capacity does not match its activities in the international arena, explaining why it is often labelled a reluctant power.

Evoy (2013) notes that Kenya's embrace of economic diplomacy during former President Mwai Kibaki's administration and the country's military intervention in Somalia in 2011 explain its foreign policy direction of non-assertiveness and reluctance to become embroiled in regional issues. The state's 2015 foreign policy and diaspora policy document (the first of its kind) that provides for a 
radical departure from erstwhile Kenyan foreign policy is also notable. The spill over effects, such as migration crises and terrorism, of conflicts in states such as Burundi, the DRC, South Sudan, and Somalia, and piracy in the region that has impacted on shipping and tourism, imply that Kenya had to abandon its erstwhile policy of non-interference.

The Ministry of Foreign Affairs and International Trade (2014: 19) outlines the objectives of Kenya's foreign policy as:

- Protect Kenya's sovereignty and territorial integrity;

- Promote sub-regional and regional integration and co-operation;

- Enhance regional and global peace and security;

- Advance the economic prosperity of Kenya and her people;

- Project Kenya's image and prestige;

- Promote international cooperation and multilateralism;

- Promote and protect the interests of Kenyans abroad; and

- Enhance partnerships with the Kenya Diaspora and descendants.

Kenya's foreign policy is also guided by the following principles:

- Sanctity of sovereignty and territorial integrity of the Republic of Kenya;

- Peaceful co-existence with neighbours and other nations;

- Resolution of conflicts by peaceful means;

- Promotion of regional integration;

- Respect for the equality, sovereignty and territorial integrity of states; and

- Respect for international norms, customs and laws.

(Ministry of Foreign Affairs and International Trade, 2014: 19)

These principles have guided successive administrations' foreign policies, with the only difference being the extent of adherence to such. It is thus clear that soft power has formed the fulcrum of Kenya's foreign policy since independence. Respect for the sovereignty of other states, peaceful co-existence, non-interference in the internal affairs of other states, and adherence to the principles of international organisations including the $\mathrm{UN}$ and $\mathrm{AU}$, are the language of soft power that redound to Kenya's positive image in the hearts and minds of its regional audience.

Kenya's foreign policy is ingrained in the country's national values and aspirations including unity in diversity, honour and patriotism, peace and liberty, justice and equity, the quest for prosperity and Harambee spirit (pulling together) (Ministry of Foreign Affairs and International Trade, 2014). It is also worth noting the five pillars of Kenya's foreign policy which exemplify the salience of soft power in Nairobi's external affairs. These include peace diplomacy, economic diplomacy, diaspora diplomacy, environmental diplomacy, and cultural diplomacy. Peace diplomacy aims to adopt peaceful means towards conflict resolution; economic diplomacy seeks to increase capital flows to Kenya; diaspora diplomacy aims to harness the diverse skills of Kenyans abroad towards national development; environmental diplomacy promotes compliance with national, regional, and 
international environmental legislation; and cultural diplomacy emphasises the promotion of cultural exchanges and partnerships. It also notes the role of Kenyan artists, athletes, and other sports persons in sports and art diplomacy.

Kenya's preference for a soft power stratagem versus a hard power approach is exemplified by the fact that, despite its mutual defence pact with Ethiopia in reaction to a possible irredentist threat for Somalia, Nairobi did not get involved in the 1977-78 war over the Ogaden region (a territory in eastern Ethiopia) between Ethiopia and Somalia, irrespective of its sympathy for Ethiopia (Emmanuel, 2016). The same scenario played out in the 1979 Uganda-Tanzania war that arose as a result of Amin's accusation that Julius Nyerere was offering support to the former's enemies (Emmanuel, 2016).

Nonetheless, like any other state, Kenya does not hesitate to deploy its hard power when its primary interests are trampled on. A case in point was former Ugandan dictator Idi Amin's irredentist posture regarding parts of Kenya's territory. Kenya responded by deploying troops on the Kenya-Uganda border and also offered covert support to Israel's popular mission to rescue its citizens held by hijackers at Entebbe Airport, Uganda in 1976 (Mabera, 2016). In contemporary times, Kenya's deployment of thousands of troops in Somalia to fight the Al-Shabaab terrorist group in 2011 marks a significant U-turn in the state's pacifist foreign policy since independence (International Crisis Group, 2012). Indeed, it is Kenya's largest military intervention since independence. While the official justification for the intervention was to halt Al-Shabaab's kidnappings of tourists in Kenya's territory, which jeopardise the country's trade and tourism that contribute significantly to its economy (Miyandazi, 2012), other likely motivations include the desire to enhance Kenya's military image and be in the good books of the West (Olsen, 2018). Given Nairobi's dovish foreign policy, the Kenya Defence Force seemed eager to prove that it could successfully wage a war against external aggression (Olsen, 2018). It is thus a matter of economic, security, and strategic interests. Almost a decade later, Kenyan troops remain in Somalia; it has, however, began negotiations to withdraw them by 2021 (Hansen, 2020). Despite Kenya's success, seen in the terrorist group's loss of control of major cities in Somalia, Al-Shabaab remains potent, as was evident in its three major attacks in Kenya between 2013 and 2019.

Indeed, Kenya's cautious foreign policy posture, as opposed to its counterparts' including Ethiopia, Uganda, and to a lesser extent Tanzania's assertive foreign policy, has caused keen observers to refer to the state as a reluctant power. To be sure, Uganda and Ethiopia have contributed substantial numbers of troops to states such as the DRC, South Sudan, and Somalia; and Tanzania's contributions to liberation struggles in Southern Africa are recognised (Emmanuel, 2016).

\section{Economic diplomacy}

The Kibaki administration's foreign policy of economic diplomacy dictated that regional economic integration be prioritised. Thus, Kenya is a very active player in the EAC. The fact that it has the largest seaport in East Africa (Mombasa) and 
is strategically located, controlling access to neighbouring states such as Burundi, the DRC, Rwanda, South Sudan, and Uganda, has fast-tracked Kenya's quest for regional integration (Evoy, 2013). Nevertheless, Kibaki's economic diplomacy is not an entirely novel idea. Post-independence, while Kenya was sceptical of Uganda's and Tanzania's enthusiasm for political integration, it vigorously advocated for economic integration of the region (Howell, 1968). Kenya prides itself on having one of the most diversified economies in Africa. The EAC provides a veritable platform for it to derive maximum export earnings. During his tenure as the chair of the organisation in 2013, Uhuru Kenyatta advocated for an EAC single currency, which is now expected to come into being in the near future (Emmanuel, 2016). This signifies Kenya's capacity to use its soft power through international institutions to champion ideas that significantly benefit the East African power. The single currency is expected to benefit, among others, the Kenyan service sector such as banking, telecommunications, and supermarkets (Emmanuel, 2016).

Mombasa is a significant soft power resource as it positions Kenya as a gateway to its neighbours. Landlocked states like Burundi, the DRC, Rwanda, South Sudan, and Uganda rely heavily on Kenya for shipment of their imported and exported goods and services. Its strategic location also makes it a pivotal state, a bridge, and an important route for the economies of East (including the Horn of Africa) and Central African states. Its role in the Common Market for East and Southern Africa (COMESA) that remains the leading destination for its exports cannot be overemphasised. It is no wonder that Kenya "is the key manufacturing, communication, commercial, and financial centre in Eastern and Central Africa and remains the region's hub and entry point for air transport" (Emmanuel, 2016: 15). Kenya's Vision 2030 takes cognisance of this reality and therefore aims to position the country as a middle-income one. In many respects, Kenya is already showing signs of leadership. It is regarded as the foremost East African state in the manufacturing, communications, and services sectors (Evoy, 2013). Kenyatta's economic diplomacy has yielded concrete benefits such as China's funding of the Standard Gauge Railway to the tune of around $\$ 3.8$ billion in 2014, and Japan's Toyota and Honda opening assembly plants in the country in 2013 (Kagwanja, 2016). The booming economy and tourist attractions have prompted tourism companies such as the Dusit Thani Group, Kempinski, Hilton International, the Marriot Group, Movenpick Hotels and Resorts, Radisson Group, Sheraton, and Tune Inn Hotels to invest in Kenya (Kagwanja, 2016).

Against the backdrop of the successful implementation of its Economic Recovery Strategy for Wealth and Employment Creation (ERS), which resulted in impressive economic growth from 0.6 per cent in 2002 to 6.1 per cent in 2006, the Kenyan government adopted Vision 2030, a long-term development strategy to enable the East African state to become an industrialising and middle-income country (Kenyan Government, 2007). The vision is based on three pillars: economic (to enhance economic development and promote prosperity); social (to build a just and cohesive society); and political (to enhance democracy, the rule of law, and individual rights). The ten-year progress report (2008-2018) highlights 
that Kenya made significant progress across the three pillars in the vision's first medium-term plan (2008-2012) and second medium-term plan (2013-2017) (Kenyan Government, 2018).

Other African states have recognised Kenya's growing economic strength on the continent. South Africa's National Planning Commission notes that South Africa's "long-term policies should ... take into account and promote the growth trajectories of both Nigeria and Kenya as economic powerhouses on the continent and join these countries in shaping the political economy of the continent and its international relations" over the next 20 to 30 years (Evoy, 2013; South African National Planning Commission, 2011: 240). Key African multinational corporations such as Nigeria's Dangote Group and South Africa's MTN are investing in Kenya.

In terms of its intervention in Somalia, al-Shabaab's activities not only threaten the survival and territorial integrity of Somalia but the entire sub-region. The possible significant impact on Kenya's economic and strategic interests informed Nairobi's decision to intervene in the conflict. This war marked the largest Kenyan military intervention in a foreign land since its independence (Emmanuel, 2016). Thus, the state seems to have acknowledged the need for an assertive foreign policy to promote its economic and strategic interests in its sub-region.

\section{Peace Diplomacy, multilateralism, and Pan-Africanism}

Kenya has exercised its soft power in peacemaking and peacebuilding and has benefitted from its status as a major regional peacemaker. While the Jomo Kenyatta administration might be considered as the honeymoon period in Kenya's foreign policy, Daniel arap Moi's regime injected the required dynamism, with this era being classified as the golden age of Kenya's foreign policy. This is perhaps best illustrated by the Moi administration's mediation role in domestic and regional conflicts in East Africa such as in Burundi, Eritrea/Ethiopia, Rwanda, Uganda, Somalia, and Zaire (now the DRC), the unprecedented number of trips he embarked on as Kenyan President, and reciprocal gestures on the part of world leaders including Pope John Paul II and Queen Elizabeth II visits in 1985 (Mabera, 2016; Emmanuel, 2016). While Kenya's interventions in these states were successful to a certain degree, some turned out to be palliative, such as the 1985 peace agreement in Uganda between then Ugandan President Tito Okello and rebel leader Yoweri Museveni. Despite the fact that Moi played a pivotal role in bringing these parties to the negotiating table to ensure that an agreement was signed that paved the way for peace, Yoweri reneged on the agreement and ousted Okello from power (Emmanuel, 2016). However, it cannot be argued that this incident substantially circumscribed Kenya's role in the sub-region. The fact that the states in East Africa accept Kenya as a capable mediator is a significant soft power booster.

It is perhaps in recognition of Moi's contribution to the cause of peace and development in Africa that he was offered the chairpersonship of the OAU, now the $\mathrm{AU}$ for an unprecedented two-year term at the expense of then Libyan ruler 
Muammar Gaddafi who showed interest in it (Emmanuel, 2016). During this period, Kenya was actively involved in peacekeeping in states such as Chad, the DRC, Liberia, Sierra Leone, Uganda, Angola, Mozambique, Namibia, and Morocco. Moi's contribution to African development was also rewarded in multilateral forums such as the Presidential Trade Area and COMESA where he served as chairperson.

Indeed, Moi's charismatic leadership accrued him significant soft power that rubbed off on Kenya and made the state a meaningful actor in African affairs. However, this dynamism dimmed during the regime of Mwai Kibaki that prioritised economic imperatives over mediation and peacemaking in its foreign policy. Kenya's regional influence declined, while Uganda's and Ethiopia's increased (Emmanuel, 2016). As noted earlier, Kenya's intervention in Somalia and Kibaki's call on the international community to pay close attention to the conflicts in Somalia and South Sudan marked a change in his foreign policy direction (Emmanuel, 2016). However, this only occurred towards the end of his tenure.

Given the West's seeming disapproval of his presidential candidacy and the ICC's charges against him, Uhuru Kenyatta took cover under the protective shield of Pan-Africanism captured by his state visits to many African states, including Ethiopia, Tanzania, Nigeria, and South Africa after his election as Kenyan president. His campaign against the ICG at the AU was instrumental in the organisation reaching consensus in 2013 for the deferral of the cases against sitting presidents (Emmanuel, 2014) and its unsuccessful consideration of all member states withdrawing from the ICC. Kenya garnered the support of 53 of the 54 African states for this deferral (Mabera, 2016). While it can be argued that his motive was personal and perhaps selfish, it cannot be denied that the Uhuru Kenyatta administration has raised the profile of Kenya's contribution to PanAfricanism. It is this ability to build consensus at local and international level that earned him the title of Africa's President of the Year in 2015 in the prestigious Africa Education and Leadership Awards. In the same year, Kenya hosted individuals such as then US president Barack Obama and Pope Francis (Mabera, 2016). This was followed by Indian Prime Minister Narendra Modi's visit in 2016 to hold talks on medical, agricultural, and energy issues, as well as Israeli Prime Minister Benjamin Netanyahu who focused on counter-terrorism and business deals (Kagwanja, 2016). In less than three years in office, Kenyatta made 69 foreign trips to promote Kenya's economic interests, facilitate peace, and work for an equitable global order, among others (Kenya Today, 2016). These are clear indications of the growing soft power appeal of the East African power.

It should be noted that Kenya has historically played this role. African unity has been a fulcrum of its foreign policy since independence. The state's first President, Jomo Kenyatta, together with Pan-Africanists such as Kwame Nkrumah, W.E.B. Du Bois, George Padmore and Hastings Banda, was a delegate to the Pan-African conference in Manchester in 1945 (Mabera, 2016). Nairobi's commitment to Pan-Africanism is also evident in its central role in expediting the 
implementation of the Tripartite Free Trade Area (TFTA), which seeks to form a commercial bloc of the 26 states of COMESA, the EAC, and SADC with the ultimate objective of enhancing economic integration, continental trade, and infrastructural and industrial development (Mabera, 2016). The TFTA provided a template for the Continental Free Trade Area, which was signed by $44 \mathrm{AU}$ member states in Rwanda in 2018. The singing of the EAC's anthem alongside the Kenyan national anthem during the twin celebration of the inauguration of Uhuru Kenyatta and the fiftieth anniversary of independence (Mabera, 2016) bear testimony to the fact that regional integration is taken seriously in the state. To demonstrate its commitment, the East African power has devised a draft regional integration policy that is aimed at, among other things, aligning domestic and regional economic policies, and taking advantage of Regional Economic Communities (REGs) in the quest to integrate into the global economy (Mabera, 2016).

In recognition of its peacemaking and peacekeeping efforts, in 2010 then UN Secretary-General Ban Ki-moon commended President Kibaki for Kenya's peace diplomacy in the region, particularly in Somalia and Sudan (Evoy, 2013). Nairobi has also emerged as the most important ally of the West in the fight against terrorism in the sub-region, evident in the fact that it is among the top five recipients of US State Department Anti-Terrorism Assistance (ATA) aid (Mabera, 2016). In pursuing peace in its sub-region through multilateral diplomacy, Kenya has benefitted from its membership of international organisations and multilateral platforms such as the IGAD, the International Conference on the Great Lakes Region, the multidimensional Eastern Africa Standby Force (EASF), the AU, the UN, the Commonwealth, the World Trade Organisation (WTO), the African, Caribbean and Pacific Group of States, the Forum on China-Africa Cooperation, the Group of 77, and the New Asia-Africa Strategic Partnership. Alongside Ethiopia, Kenya has deployed the platform of the IGAD to address the conflicts in South Sudan and Somalia. Kenya is the premier host country for regional and even global peace and security summits and conferences. Examples include the 2012 and 2013 talks on the political future of Somalia's Jubbaland region, and the 2012 international anti-piracy conference (co-hosted with the UN) (Evoy, 2013). Nairobi hosted the sixth Tokyo International Conference on African Development (TICAD), drawing 36 heads of state to Kenya and an 80-member delegation from Japan (Kagwanja, 2016). It is the only country outside Japan to have hosted this event. Kenya has also supported $\mathrm{UN}$ and $\mathrm{AU}$ peacekeeping efforts.

At the level of the AU, Kenya has actively participated in the stabilisation process in states such as the CAR, the DRC, Guinea Bissau, and Mali (Ministry of Foreign Affairs and Trade, 2016). Nairobi lobbied for the integration of its defence force into the African Union Mission in Somalia (AMISOM), culminating in the expansion of the AMISOM mandate from peace keeping to peace enforcement. It also played a major role in brokering the peace deal that resulted in the independence of South Sudan and peaceful elections in 2011. Peacemaking and multilateralism are thus important means by which Kenya has 


\section{Kenya}

exhibited its soft power. Nye (2004) notes that some states' hard power resources do not equate to significant influence in international affairs. This is because such states depend on the attractiveness of their soft power in the realms of multilateral foreign policy and peacemaking. It is within this context that one can locate Kenya's peacemaking and multilateral foreign policy in African affairs.

At the level of the UN, Kenya advocates for South-South cooperation towards reforming the organisation to achieve representative and equitable global governance. While acting as a co-chair of the open working group on the post-2015 development agenda, Kenya played a significant role in inter-governmental negotiations that resulted in the adoption of the 2030 Agenda for Sustainable Development. Its multilateral posture paid off when it won the bid to host the tenth WTO Ministerial Conference in 2015 (Mabera, 2016), the first African state to achieve this. The country also played an important role in the negotiation of Rhodesia's (now Zimbabwe) independence in 1980 and provided military support for the UN transitional Assistance Group that resulted in Namibia's independence in 1990 (Mabera, 2016). Kenya's commitment to the work of the $\mathrm{UN}$ is captured by its remarkable contribution to the organisation. For instance, in 2015 Forbes included Kenya in the list of ten states that make the highest contributions to the UN. With a contribution of $\$ 445$ million, it was the only African state on the list that included great powers such as the United States, France, the UK, and India (Kagwanja, 2016). Again, this is testimony to Nairobi's preference for soft power in international affairs.

\section{Kenya's soft power constraints}

\section{Kenya and the international criminal court: David versus Goliath}

Cases before the ICG relating to Kenya have significantly shaped Nairobi's foreign policy. The violence associated with the 2007 general elections led to more than 1,000 deaths and over 650,000 internally displaced persons. The report of the Commission of Inquiry on Post-Election Violence (CIPEV) identified the perpetrators of the violence and recommended the establishment of a special tribunal (Mabera, 2016). Following the Kenyan government's dragging of its feet to set up the tribunal, the commission referred the alleged six perpetrators including current President Uhuru Kenyatta; current Deputy President William Ruto; Francis Muthaura, then Head of the Civil Service; Hussein Ali, then Police Commissioner; Henry Kosgey, then Minister for Industrialisation; and Joshua arap Sang, a journalist - to the ICC in 2009 (Lugano, 2017).

Deliberations on the adoption of the Rome Statute in Kenya started in 1998 during the autocratic rule of Daniel arap Moi. Nevertheless, due to domestic pressure from various human rights groups, Nairobi signed the statute in 1998 with a principle on non-retroactivity, implying that Moi and his supporters could not be prosecuted for their human rights violations (Lugano, 2017). Kenya ultimately ratified the statute in 2005 . 
In 2010, the ICG announced that it was summoning six people from Kenya, accusing them of committing crimes against humanity including murder, deportation or forcible transfer, rape, and other forms of sexual violence (Human Rights Watch, 2011). The ICC quagmire was a crucial topic in these individuals' campaigns in the run-up to the 2013 presidential elections, when they rejected the court as a Western imperial machine to control Africa. Kenyatta and Ruto, who formed an alliance of different parties to contest the presidential elections, seem to have used their ticket to ignite anti-ICG sentiments in Kenya. In one of Kenyatta's public statements, he noted that "A vote for us is a vote of no confidence in the ICC" while, for his part, Ruto stated that "Presidential victory for the Jubilee Alliance may indicate there is something wrong with the charges its two leaders are facing at The Hague" (Kendall, 2014: 411).

It is important to stress that Kenya ratified the Rome Statute - which established the ICG - in 2005 and thus non-compliance with international law seemingly dilutes Nairobi's soft power. However, the Kenya-ICG relationship and its implications for the former's soft power is somewhat complicated. What seems to be clear is that while the ICG imbroglio punctured Kenya's image in the international arena, it did not have a significant effect on its power of attraction in Africa. Indeed, it perhaps reinforced admiration for Nairobi. This is best captured by the tussle between the AU and the UN on the matter. At the AU summit in 2013, a resolution was adopted calling on the UN Security Council to consider deferring the cases against the two Kenyan politicians - Kenyatta and Ruto - for a year, pointing out that these cases posed a distraction to the capacity of these individuals to discharge their domestic and regional responsibilities (Mabera, 2016). However, the UN Security Council declined to accede to the request, reinforcing the dilemma of wielding soft power at regional and global level. Thus, while the ICG seemed to have the support of many great powers and key NGOs like Human Rights Watch, Kenya had overwhelming backing across Africa.

In 2009, the AU had suggested the establishment of an African court to try crimes against humanity and called on African states not to cooperate with the ICG in terms of its arrest and surrender orders. In 2017, the AU adopted a "withdrawal strategy" calling for African solutions to African challenges, preservation of the dignity and sovereignty of African states, and reform of the ICC, among other things (Mills and Bloomfield, 2017). While this did not literally request African states to withdraw, it assessed the potential of withdrawal. This notion has received significant support because of perceptions that the ICC is targeting African leaders. Table 6.3 shows the cases investigated by the ICG.

The impasse between Kenya and the ICC ended in the termination of the case against Kenyatta in 2014 due to inadequate evidence and against Ruto in 2016 in a mistrial ruling (Lugano, 2017). While there are claims and counter-claims on the part of both parties over Kenya's cooperation with the ICG in its investigations, the bottom line is that rather than Kenya, it was the ICC that lost face. The court's legitimacy in Africa declined due to the fact that all the cases before it concerned Africa, creating the impression that Africans were being targeted. 
Table 6.3 International Criminal Court cases

\begin{tabular}{ll}
\hline Status & Cases \\
\hline Pre-trial & Ali Muhammad Ali Abd-Al-Rahman (Sudan); Omar Al \\
& Bashir (Sudan); Mahmoud Al-Werfalli (Libya); Walter \\
& Barasa (Sudan); Saif Al-Islam Gaddafi (Libya); Paul Gicheru \\
& and Philip Kipkoech Bett (Kenya); Ahmad Harun (Sudan); \\
& Abdel Raheem Muhammad Hussein (Sudan); Al-Tuhamy \\
& Mohamed Khaled (Libya); Joseph Kony et al (Uganda); \\
& Sylvestre Mudacumura (Rwanda); Simone Gbagbo (Côte \\
& d'Ivoire) \\
& Al Hassan Ag Abdoul Aziz (Mali); Abdallah Banda (Sudan); \\
& Bosco Ntaganda (DRC); Dominic Ongwen (Uganda); Alfred \\
& Yekatom and Patrice-Edouard Ngaïssona (CAR) \\
& Jean-Pierre Bemba Gombo et al (DRC); Laurent Gbagbo \\
Trial & and Blé Goudé (Côte d'Ivoire) \\
& Ahmad al-Mahdi (Mali); Germain Katanga (DRC); Thomas \\
& Lubanga Dyilo (DRC) \\
Appeal & Abu Garda (Sudan); Jean-Pierre Bemba Gombo (DRC); \\
Reparation/ & Uhuru Kenyatta (Kenya); Callixte Mbarushimana \\
Compensation & (Rwanda); Mathieu Ngudjolo Chui (DRC); William Ruto \\
Closed & and Joshua Arap Sang (Kenya) \\
\hline
\end{tabular}

Source: author's adaptation from the ICC's website.

Coupled with the ICG's 2009 decision to arrest Sudan's President Omar alBashir, by 2016 three African states had declared their intention to leave the court (Mills and Bloomfield, 2017) and there was an unsuccessful call for African states to do so en masse. Since 2013, when the Kenyan parliament voted to withdraw (which President Kenyatta did not act upon), several African states have indicated their resolve to do so, including Burundi, South Africa, Namibia, and the Gambia, all in 2016 (Mills and Bloomfield, 2017). Against this backdrop, save for the West, Kenya's tussle with the ICG has at worst not undermined the East African country's power of attraction, and at best enhanced its soft power at regional level.

\section{Electoral violence}

The announcement of Kenya's presidential election results in December 2007 resulted in electoral violence that the country had not witnessed since the start of multiparty politics in 1992. There were more than 1,000 deaths and 650,000 displaced persons (Elder et al., 2014). Although Kenya had witnessed postelection violence since 1992, the 2007 elections presented a unique case due to the tensions associated with constitutional reform and the 2005 referendum in the immediate period before the 2007 elections, coupled with a flawed electoral process (Department for International Development, 2010). Problems associated with the electoral process resulted in the deepening of already complicated ethnic divisions and post-election violence until 2008 (Department for International 
Development, 2010). Despite calls for a recount of the votes by many Kenyan citizens, opposition parties, and international observers, Kibaki was hurriedly sworn in (in the presence of a few guests) for his second term immediately after the announcement of his victory. This reinforced widespread perception that the election was massively rigged in favour of the incumbent (Kagwanja and Southall, 2009). Despite the relative violence that accompanied previous elections, Kenya was still widely perceived as a peaceful and stable state in the midst of a continent that has many theatres of conflict. The 2007 elections and the attendant violence shattered these positive perceptions. Kagwanja and Southall (2009: 260) assert:

Customarily hailed as a relatively peaceful and stable haven in the turbulent continent, in the post violence period the country has come to signify the tragic slide from the optimism that greeted the global "third wave" of democracy as it swept Africa in the early 1990s to pessimism and despair.

This led the international community to move swiftly to assist the East African state. Then UN Secretary General Kofi Annan provided the mediation required for the formation of the coalition government of Mwai Kibaki (President) and Raila Odinga (Prime Minister) and a peace agenda was formulated, including the adoption of a new constitution, setting up an electoral commission, and reform of the judiciary, all aimed at preventing the recurrence of violence in the future (Elder et al., 2014). Other important steps included early warning systems and capacity-building initiatives. However, the fact that many of these initiatives were not completed before the 2013 elections, coupled with high levels of unemployment, inequality, and ethnicity, led many commentators to predict the post-election violence witnessed in 2007-2008 (Elder et al., 2014).

Following the relatively peaceful elections in 2013, international observers and actors commended Kenya for what were described as successful, peaceful, and credible elections. However, Elder et al.'s (2014) study shows that Kenyan citizens disagreed with these assessments, with respondents pointing to high levels of tension and political violence that varied from county to county. This was complicated by a series of blunders by the Independent Electoral and Boundaries Commission (IEBC) such as the failure of the biometric system which resulted in only two-thirds of eligible voters being registered and the eventual use of manual vote tallies (Long et al., 2013). With 50.07 per cent of the electoral votes, then deputy Prime Minister Uhuru Kenyatta won the 2013 elections, and then Prime Minister Raila Odinga obtained 43.31 per cent of the electoral votes (Long et al., 2013).

Its weak institutions and flawed electoral process have resulted in Kenya being regarded as one of Africa's failed democracies (Kagwanja and Southall, 2009). It is now viewed as a state characterised by electoral violence, with international observers no longer shocked by recurrent violence given the persistent triggers of conflict such as corruption, high levels of poverty and inequality, elite fragmentation, and ethnicity (Kagwanja and Southall, 2009). 
Clearly, the emergence of multiparty politics in the early 1990s was not accompanied by public trust in the electoral process, evident in the opposition's contestation of election results between 1992 and 2017, with the only notable exception being the 2002 elections. Given Kenya's regional position and influence, and its recurrent electoral violence, the East African power attracts many local and international observers. There were more than 10,000 observers from intergovernmental organisations in the 2017 elections, including: the AU, the Commonwealth Observer Group (COG), and the European Union (EU); subregional organisations like the EAC, International Conference of the Great Lakes Region, and the IGAD; NGOs such as the Carter Center (TCG) and National Democratic Institute (NDI); and local observers (Nginya, 2018). Tensions rose following the 2017 elections when opposition candidate Raila Odinga of the National Super Alliance (NASA), which gained 45 per cent of the votes, called a press conference to challenge the outcome that declared incumbent President Uhuru Kenyatta of Jubilee Party the winner (having accrued 54 per cent of the votes) on the basis of irregularities, despite the fact that international observers had contrary opinions. Odinga challenged the results in the Supreme Court, with the Court annulling the elections and calling for fresh presidential elections, which were held in October.

In the run-up to the elections, many residents of key areas like Huruma, Mathare, Naivasha, Nakuru, and Kibera moved from their homes to places where their ethnic groups were in the majority as citizens feared the elections would ignite ethnic violence (Mutahi and Ruteere, 2019). As it turned out, instead, Kenya witnessed high levels of police violence (Fjelde and Höglund, 2018). Among other things, two major factors explain the low levels of interethnic violence. The first was the devolution of power from the president to 47 new county governments guaranteed by the 2010 constitution (Cheeseman et al., 2019) and the second was the fact that the President and Deputy President, Kikuyu and Kalenjin, were from different major ethnic groups, promoting unity in the run-up to the elections.

Following the declaration of Kenyatta as the winner, there were protests in Raila Odinga's strongholds such as Kisumu, Homa Bay, Mathare, Kibera, and Kisii. In response, the police used lethal force, including live ammunition, with many people beaten to death and several women raped (Mutahi and Ruteere, 2019). The police already had a heavy presence in NASA strongholds in anticipation of protests, and around 100 people died (mostly from the Luo, Odinga's ethnic group) following both elections (Chege, 2018). This punctured Kenya's image in the eyes of international observers that witnessed the police's high handedness and human rights abuses, creating the impression that Kenya is just another illiberal democracy.

Electoral violence in Kenya has also had a significant impact on FDI as investors seek a stable political environment and favourable economic policies. For example, due to expectations of violence in the 2017 elections, industries reduced production and withheld their capital, while contiguous states used Tanzanian ports in lieu of Kenya's (Matilda, 2018). The annulment of the 
August elections had instant and dire economic consequences, with the Nairobi Stock Exchange (NSE) - the largest in East and Central Africa - losing \$920 million a day after the nullification (Matilda, 2018). The private sector lost $\$ 7,000$ million and foreign investors' interest in the NSE declined from 72.4 per cent in April to 49.1 per cent in July (Matilda, 2018). This clearly shows that a stable political system and strong macro-economic environment is an important source of a state's attractiveness to other states and MNCs.

\section{The constraint of ethnicity}

Closely related to electoral violence is the hegemony of ethnicity in Kenya's governance deficit. This was demonstrated in the violence in the 1992, 1997, and 2007 elections, which was bound up in ethnicity as politicians played the ethnic card to achieve their selfish interests. Politicians rely heavily on their ethnic groups for mobilisation. Ethnicity is one of the legacies of colonialism that not only manifests in group identity but also in pursuing economic interests (Kwatemba, 2008) and political power. The notion of nationalism that guided Kenya's founding fathers', such as Jomo Kenyatta and Oginga Odinga, approach to independence from the British, has quickly given way to ethnic considerations in the post-independence period as the major political parties, the Kenya African National Union (KANU) and the Kenya African Democratic Union (KADU), are ethnic political groups. Immediately after independence, Jomo Kenyatta played the ethnic card to consolidate his power and form a one-party government, allocating key positions to his group (the Kikuyu); marginalised other nationalists including Odinga, and created a blurred line between party and ethnic group (Kwatemba, 2008). The same scenario manifested during Moi's administration (although he ostensibly fought against ethnicity). The main difference was that Moi's Kalenjin community was the beneficiary of the government's neopatrimonialism (Kwatemba, 2008). Kibaki also placed members of his ethnic group (Kikuyu) in strategic positions in the cabinet, key government parastatals, and the civil service in order to consolidate his power. Successive Kenyan administrations have fallen into the selfsame trap of ethnic chauvinism.

In the run-up to the 1992 elections, conflict between supporters of the Kalenjin majority ruling party KANU and the ethnic groups supporting the opposition resulted in 779 deaths and over 56, 000 displaced persons (Cho et al., 2015). After the 1997 elections, conflict erupted between KANU supporters and other ethnic groups, leaving more than 200 dead and displacing over 100,000 people (Cho et al., 2015). The 2002 polls that recorded negligible ethno-political violence were the exception partly due to the fact that the two main presidential candidates were from the same ethnic group - Kikuyu. In the lead-up to the 2007 elections, hate speech and inflammatory remarks about individuals, political parties, and other ethnic groups punctuated the campaign (Cho et al., 2015). It therefore came as no surprise that clashes occurred following the elections, especially in Nairobi and the Rift Valley. While this was initially thought to have been violence between the winning and opposition parties, it turned out that it 
was largely organised along ethnic lines. For example, in the Rift Valley, the Kalenjin ethnic group that supported the ODM carried out attacks on the Kikuyu, Kamba, and Kisii that favoured Kibaki's Party of National Unity (PNU) (Cho et al., 2015). Retaliatory Kikuyu attacks targeted the majority ethnic groups in the ODM including the Kalenjin, Luo, and Luhya including the burning of a family of eight in Naiyasha (Chege, 2008). The violence resulted in 1,200 deaths, with 650,000 people displaced (Cho et al., 2015). This significantly damaged Kenya's attraction across the world and reinforced perceptions of Africa as a theatre of ethnic conflict. It prompted the New York Times to describe the electoral violence as "tapped into an atavistic vein of tribal tension that always lay beneath the surface in Kenya but until now had not produced widespread mayhem" (Chege, 2008: 125). Rather than promoting national consciousness, Kenyan political elites have mobilised their ethnic constituencies to advance their narrow interests, thereby creating divisions which manifest in the in-group and outgroup. The in-group is the group in power that benefits from patron-client relationships while the out-group is marginalised. This situation redounds in violence and has dire consequence for Kenya's international image.

It should, however, be noted that, despite the high level of ethnic tension in Kenya, the East African state has not witnessed a full blown civil war or a coup d'état as experienced in many African states. It thus seems that much of Kenya's ethnic clashes are triggered by electoral violence.

\section{Political corruption}

Although Kenya has made progress in democratisation since the 1990s, seen in the relative checks and balances that exist between the three arms of government, political corruption has undermined this. Corruption and abuse of power is pervasive across all levels of government, begging the question of how the legislature and judiciary are able to hold the executive arm accountable.

The legislature is regarded as an institution that has been captured by powerful elites and citizens have lost faith in the judiciary. For example, the violence that erupted after the 2007 elections is partly attributed to the judiciary's inability to play its part in dispute resolution due to its lack of independence (Migai, 2011). Presidents, ministers, and civil servants in the top echelons often use their positions to influence junior colleagues to engage in corrupt practices, sometimes against their wishes (Migai, 2011). Civil servants that are uncooperative risk being suspended, redeployed, and, in extreme cases, dismissed. This was seen in the case of Jacinta Mwatela, former Deputy Governor of the Central Bank. Mwatela was transferred to the Ministry of Development as she was regarded as an obstacle because she declined to approve a tender for the printing of new currency on the basis that this would be in violation of the Public Procurement and Disposal Act of 2005 (Migai, 2011). Corruption has had a negative impact on Kenya's image as foreign donors and international financial institutions such as the IMF and World Bank are increasingly concerned about how grants and loans are managed and have therefore prescribed 
conditionalities (Harrington and Manji, 2012). The quest for democratisation has thus been championed by civil society actors with the support of foreign donors including the United States and European states (Harrington and Manji, 2012). Due to corrupt practices, in 2010, the UK suspended its funding for free elementary education in the country as it had discovered that $\mathcal{E}_{880,000}$ of the initial budget of $£ 20$ million had been diverted for another purpose (Harrington and Manji, 2012). This is one of the major corruption scandals in Kenya that have cost the country hundreds of millions of dollars (Harrington and Manji, 2012) and undermined Nairobi's image in the international arena. Other highprofile cases of corruption include: the Turkwel Hydroelectric Power Station scandal (1986-1990); the Goldenberg scandal (1990-1993); the Anglo-Leasing Procurement scandal (2005); the Grand Regency Hotel scandal (2008); the Triton Oil Corruption scandal (2009); the Chicken Gate scandal (2014); and the CMC di Ravenna corruption scandal (2019). In the Grand Regency Hotel scandal, it was alleged that the Central Bank of Kenya fraudulently sold the hotel to the Libya Arab Investment Company (LAICO). It was revealed that the hotel was sold at 2.7 billion Kenyan shillings below its value of 7 billion shillings (Kenya Human Rights Commission, 2018). The allegation that the Kibaki government proposed the sale further aggravated the situation. With regard to CMC di Ravenna, two hydropower and irrigation dams were supposed to be constructed in the Rift Valley Region. An Italian company, CMC di Ravenna, was awarded the contract but construction was not forthcoming despite a payment of $\$ 180$ million that was made for projects to 28 people (including Henry Rotich, the finance minister) (Mpungu, 2019). As it turned out, the original contract that stated that the Italian company would finance the projects was revised to enable the Kenyan government to borrow the funds totalling \$609 million from European banks (Mpungu, 2019).

Despite several attempts by donors and international financial institutions to place Kenya on the path of public sector reform and to tackle graft through support for anti-corruption initiatives, corruption remains endemic in the country. The United States and Germany allocated $\$ 9$ million to the establishment of an Anti-Corruption Commission in Kenya. However, the amount was subsequently reduced following mismanagement of the commission (Harrington and Manji, 2012). The ubiquity of corruption in Kenya prompted Edward Clay, then British High Commissioner to Kenya, to deliver scathing speeches to British business owners and Kenyan journalists, in 2014 and 2015 respectively, in Nairobi (Harrington and Manji, 2012), further undermining Kenya's image. A survey conducted in 2016 by the Kenyan Ethics and Anti-Corruption Commission (EACG) revealed that 79.3 per cent of Kenyans felt that the levels of corruption in the country were very high and perceived corruption as the third major challenge confronting the country after poverty and unemployment (Kenya Human Rights Commission, 2018).

The high levels of political corruption in Kenya have clearly dented its international image. As international NGO, the Open Society Foundations (2015: 43), noted: 
Table 6.4 Kenya's ranking in the Corruption Perception Index

\begin{tabular}{lllllll}
\hline Year & 2015 & 2016 & 2017 & 2018 & 2019 & 2020 \\
\hline $\begin{array}{l}\text { Score/Scale } \\
\text { Rank/Number }\end{array}$ & $25 / 100$ & $26 / 100$ & $28 / 100$ & $27 / 100$ & $28 / 100$ & $31 / 100$ \\
$\begin{array}{l}\text { of countries } \\
\text { surveyed }\end{array}$ & $139 / 168$ & $145 / 176$ & $143 / 180$ & $144 / 180$ & $137 / 180$ & $124 / 180$ \\
\hline
\end{tabular}

Source: author's adaptation from Transparency International (2016-2021).

Kenya's peculiar problem is impunity. This explains why, despite bribery and corruption having been criminalised since 1956, with over a dozen major legislative amendments being enacted to better codify the offences, increase penalties and create new anti-corruption institutions, Kenyans are hard pressed to name a single major corruption prosecution, let alone a conviction, for such notorious crimes. For all the civil-society investment in agitation against corruption, and despite the obviously enlightened Kenyan public seeing the economically deleterious effects of corruption, the menace is not a political issue that wins votes.

Table 6.4 reflects Kenya's poor ranking in the Corruption Perception Index. This has dire consequences for the country's capacity to attract FDI and tourists.

\section{References}

Africa Policy Institute (2018). "Humanitarian Diplomacy." https://www.africapi.org/ humanitarian-diplomacy/.

Allison, L. and Monnington, T. (2005). "Sport, Prestige and International Relations." In: Allison, L. (ed.), The Global Politics of Sport: The Role of Global Institutions in Sport. London: Routledge, pp. 5-23.

Busolo, M. (2016). The Role of Sports Diplomacy in African International Relations: The Case of Kenya. Nairobi: University of Nairobi.

Byron, K. and Chepyator-Thomson, J. (2015). "Sports Policy in Kenya: Deconstruction of Colonial and Post-colonial Conditions." International Fournal of Sport Policy and Politics 7 (2): 301-313.

Chatterjee, S. (2018). "Kenya - Overcoming Rivalry \& Conflict through Cultural Diplomacy." Inter Press Service Newes Agency. April 27. http://www.ipsnews.net/2018/04/kenya -overcoming-rivalry-conflict-cultural-diplomacy/.

Cheeseman, N., Kanyinga, K., Lynch, G., Ruteere, M., and Willis, J. (2019). "Kenya's 2017 Elections: Winner-takes-all Politics as Usual?” Gournal of Eastern African Studies 13 (2): 215-234.

Chege, M. (2008). "Kenya: Back from the Brink?” Gournal of Democracy 19 (4): 125-139.

Chege, M. (2018). "Kenya's Electoral Misfire.” Journal of Democracy 29 (2): 158-172.

Cho, S., Connors, E., Fatima, F., and Yalim, U. (2015). Preventing Post-Election Violence Based on the Kenyan Experience. California: Stanford University Press.

Department for International Development (2010). Elections in Kenya in 2007. London: Department for International Development. 
Elder, C., Stigant, S., and Claes, J. (2014). Elections and Violent Conflict in Kenya: Making Prevention Stick. Washington, DC: United States Institute of Peace.

Emmanuel, K. (2014). Kenya's Regional Relations: Between Principle and Practice. South African Institute of African Affairs. South African Foreign Policy and African Drivers Programme. Policy Briefing 113.

Emmanuel, K. (2016). Kenya's Regional Diplomacy: Peripheral or Adaptive Pragmatism? South African Institute of International Affairs Occasional Paper 248.

Evoy, C. (2013). Shifting Priorities: Kenya's Changing Approaches to Peacebuilding and Peacemaking. Norwegian Peacebuilding Resource Centre.

Fjelde, H. and Höglund, K. (2018). "Ethnic Politics and Elites Competition: The Roots of Electoral Violence in Africa." In: Kovacs, M. and Bjarnesen, J. (eds), Violence in African Elections: Between Democracy and Big Man Politics. London: Zed Books, pp. 27-46.

Global Fire Power (2020). "2020 Military Strength Ranking." https://www.globalfirep ower.com/countries-listing-africa.asp.

Global Tourism Forum (2020). "Kenya Tourism Sector Performance in 2019." 16 January. https://www.globaltourismforum.org/blog/2020/01/16/kenya-tourism-sector-p erformance-in-2019/.

Hansen, S. (2020). "What Kenya Stands to Lose and Gain By Withdrawing From Somalia." The Conversation, 30 April. https://theconversation.com/what-kenya-stands-to-lo se-and-gain-by-withdrawing-from-somalia-133640.

Harrington, J. and Manji, A. (2012). "Satire and the Politics of Corruption in Kenya." Social \& Legal Studies 22 (1): 3-23.

Howell, J. (1968). "An Analysis of Kenyan Foreign Policy." The Zournal of Modern African Studies 6 (1): 29-48.

Human Rights Watch (2011). Kenya and the International Criminal Court Questions and Answers. New York: Human Rights Watch.

International Crisis Group (2012). The Kenyan Military Intervention in Somalia. Africa Report no. 184. Brussels: International Crisis Group.

International Trade Centre (2016). Cotton, Textile and Apparel Sector Investment Profile: Kenya. Geneva: International Trade Centre.

Kagwanja, P. (2016). "Economic Diplomacy Transforming Kenya into a Global Soft Power." Daily Nation, September 4. https://www.nation.co.ke/oped/opinion/Economic-diploma cy-transforming-Kenya-into-a-global-soft-power/440808-3368446-1407fhl/index.html.

Kagwanja, P. and Southall, R. (2009). "Introduction: Kenya - A Democracy in Retreat?" Journal of Contemporary African Studies 27 (3): 259-277.

Kendall, S. (2014). "'UhuRuto' and Other Leviathans: The International Criminal Court and the Kenyan Political Order." African Fournal of Legal Studies 7: 399-427.

Kenya Human Rights Commission (2018). Exposing the Governance Conundrum in Kenya: Deep State, Mega-Corruption and Stalled Electoral Reforms. Nairobi: Kenya Human Rights Commission.

Kenya Today (2016). "Breaking: President Kenyatta Makes 69 Foreign Trips in Less than 3 Years." 3 March 2016. https://www.kenya-today.com/politics/breaking-president-ke nyatta-makes-69-foreign-trips-less-3-years-2.

Kenyan Government (2007). Kenya Vision 2030: The Popular Version. Nairobi: Kenyan Government.

Kenyan Government (2018). Kenya Vision 2030: Marking Ten Years of Progress (2008-2018). Nairobi: Kenyan Government.

Kwatemba, S. (2008). "Ethnicity and Political Pluralism in Kenya." Journal of African Elections 7 (2): $77-112$. 


\section{Kenya}

Larsen, H. and Sheel, A. (2015). "The Kenyan Runners." Scandinavian Fournal of Medicine and Science in Sports 25 (4): 110-118.

Long, J., Kanyinga, K., Ferree, K., and Gibson, C. (2013). "Kenya's 2013 Elections: Choosing Peace over Democracy." Journal of Democracy 24 (3): 140-155.

Lugano, G. (2017). "Assessing the Acceptance of International Criminal Justice in Kenya." In: Buckley-Zistel, S., Mieth, F., and Papa, M. (eds), After Nuremberg. Exploring Multiple Dimensions of the Acceptance of International Criminal Fustice. Nuremberg: International Nuremberg Principles Academy.

Mabera, F. (2016). "Kenya's Foreign Policy in Context (1963-2015)." South African Fournal of International Affairs 23 (3): 365-384.

Matilda, O. (2018). "The Impact of Electoral Violence on Economic Development: A Case of Kenya." Fournal of Political Science and International Relations 1 (3): 55-71.

Migai, A. (2011). "Abuse of Power and Corruption in Kenya: Will the New Constitution Enhance Government Accountability." Indiana Fournal of Global Legal Studies 18 (1): 341-394.

Mills, K. and Bloomfield, A. (2017). "African Resistance to the International Criminal Court: Halting the Advance of the Anti-impunity Norm." Review of International Studies 44 (1): 101-127.

Ministry of Foreign Affairs and International Trade (2014). Kenya Foreign Policy. Nairobi: Ministry of Foreign Affairs and International Trade.

Ministry of Foreign Affairs and International Trade (2016). Strategic Plan 2013/14-2017/ 18. Nairobi: Ministry of Foreign Affairs and International Trade.

Miyandazi, L. (2012). Kenya's Military Intervention in Somalia: An Intricate Process. Policy \& Practice Brief Issue 19. Durban: The African Centre for the Constructive Resolution of Disputes.

Mpungu, P. (2019). “Kenya's Corruption Crackdown: New Era, or Political Theatre?” 27 July 2019. https://www.aljazeera.com/ajimpact/kenyas-corruption-crackdown-era-poli tical-theater-190726154554617.html.

Mutahi, P. and Ruteere, M. (2019). "Violence, Security and the Policing of Kenya's 2017 Elections." Fournal of Eastern African Studies 13 (2): 253-271.

Mwanika, P. (2013). Track-One Diplomacy and Post-Conflict Reconstruction: Kenya's Mediation of the Somali Conflict and Strategic Intervention Avenues. Submitted in fulfilment of the requirements for the degree of Doctor Philosophiae (D. Phil) in the Faculty of Business and Economic Sciences, Nelson Mandela Metropolitan University, Port Elizabeth, South Africa.

Nginya, M. (2018). "International Election Observers in Kenya's 2017 Elections: Impartial or Partisan?" Fournal of African Elections 17 (1): 49-71.

Njiru, J. (2016). The Role of Cultural Diplomacy as a Tool for Advancing African Foreign Relations: A Case Study of Kenya. Master's Thesis. University of Nairobi College of Humanities and Social Sciences Institute of Diplomacy and International Studies.

Nye, J. (2004). Soft Power: The Means to Success in World Politics. New York: Public Affairs.

Olsen, G. (2018). "What Kenya Has to Show for Sending Troops into Somalia Seven Years Ago." The Conversation, 18 February. https://theconversation.com/what-kenya-ha s-to-show-for-sending-troops-into-somalia-seven-years-ago-90965.

Open Society Foundations (2015). Effectiveness of Anti-Corruption Agencies in East Africa: Kenya, Tanzania and Uganda. New York: Open Society Foundations.

Orora, J. and Spiegel, H. (1980). "Harambee: Self-Help Development Projects in Kenya." International Fournal of Comparative Sociology 21 (3/4): 243-253.

Oxford Business Group (2018). "Tourism Rises in Kenya Once Again.” https://oxfordbusi nessgroup.com/overview/back-track-after-period-decline-tourism-sees-its-fortunes-rise. 
Singleton, J. (2012). “Athletics, Kenya.” In: Nauright, J. and Parrish, C. (eds), Sports Around the World: History, Culture, and Practice. Santa Barbara, CA: ABC-CLIO, LLC.

South African National Planning Commission (2011). National Development Plan 2030: Our Future - Make It Work. Pretoria: South Africa's National Planning Commission.

The Kenyan Textile and Fashion Industry Report (2016). The Kenyan Textile and Fashion Industry: The role of fashion designers and small tailors in the fibre to fashion value chain. Nairobi: Hivos East Africa Office.

Transparency International (2016-2021). "Corruption Perceptions Index." https://www. transparency.org/en/cpi.

Tucker, R., Onywera, V., and Santos-Concejero, J. (2015). "Analysis of the Kenyan Distance-Running Phenomenon." International Fournal of Sports Physiology and Performance 10: 285-291.

Wamanji, E. (2016). "Kenya Can Use Sports as Strategic Diplomatic Tool." People Daily. May 11. https://mediamaxnetwork.co.ke/people-daily/kenya-can-use-sports-as-stra tegic-diplomatic-tool-219379/amp/.

World Athletics (2019). "Medal Table." https://www.worldathletics.org/Competitions/world-a thletics-championships/iaaf-world-athletics-championships-doha-2019-7125365/medaltable.

World Bank (2019). World Development Indicators. Washington, DC: World Bank.

World Travel and Tourism Council (2018). The Economic Impact of Travel and Tourism: Kenya. London: WTTC.

World Travel and Tourism Council (2020). Travel and Tourism: Global Economic Impact and Trends 2020. London: WTTG. 


\title{
7 Conclusion
}

\author{
Africa as a model
}

Soft power is not often associated with Africa. This stems from the negative images, from diseases to war, terrorism, poverty, and crime that have characterised perceptions of the continent, creating the impression that Africa lacks agency. However, there are positive images coming out of Africa and the fact that these remarkable aspects of the continent are ignored or under-reported by global media does not imply that they do not exist. It is equally germane to note that the world is recognising this reality, as perceptions of Africa as a backward continent are increasingly being challenged. It is within this context that one can understand the notion of "Africa Rising", the successful 2010 FIFA World Cup hosted by South Africa, Pretoria's liberal constitution (considered as one of the most progressive in the world), Nigeria's Nollywood (the second largest movie industry in the world), Kenya's success in athletics, Egypt's status as the cradle of civilisation, and Rwanda's status as the world champion of gender equality.

The notion of "Africa Rising" was popularised by The Economist in 2011, 11 years after the same publication labelled Africa "the hopeless continent". This change of heart was largely due to high economic growth rates and remarkable economic performance across the continent. While doubt has been cast on this narrative recently (particularly since 2015) due to the poor economic performance of the regional powers, especially Nigeria and South Africa, it remains relevant as African countries dominated the top ten fastest growing economies prior to the emergence of COVID-19, with Rwanda being the fastest growing, achieving a 7.7 per cent growth rate. This dictates that Africa remains the future of the global economy and provides a model for economic growth. It is no wonder that the twenty-first century has been characterised by renewed interest in the continent, generating what some have described as a new or second "scramble for Africa".

Africa has indeed developed agency around the notion of African solutions to African challenges, which finds practical expression in the AU's Agenda 2063 - a normative and strategic framework that seeks to ignite Africa's growth and development and position the continent as a global force. Indeed, Africa has exercised soft power and provided models for the world on many levels. In terms of good governance, with more than 60 per cent female representation in parliament, Rwanda provides a model in the area of gender equality, while South Africa's constitution offers a template for constitutionalism.

DOI: $10.4324 / 9781003176022-7$ 
The global popularity of African cultural exports, including films, music, literature, and fashion, is increasing. African literary icons like Nigerian Wole Soyinka, Egyptian Naguib Mahfouz, and South African John Maxwell Coetzee have won the Nobel Prize for Literature. Popular African music artists in the diaspora, especially Senegalese Akon and Nigerian Jidenna, have identified with their ancestral roots in their lyrics and dress codes. Top African artists such as Davido, Wizkid, DJ Maphorisa, AKA, and Diamond have collaborated with top American artists including Drake, Nicki Minaj, Chris Brown, Beyoncé, Ne-Yo, Meek Mill, and Rick Ross. African fashion has also taken the world by storm, with Western designers like Louis Vuitton, Yves Saint Laurent, and Paul Smith drawing inspiration from African designs and prints; and top celebrities and influential figures such as Michelle Obama, Beyoncé Knowles, Rihanna, Alicia Keys, Kim Kardashian, Gwen Stefani, and Nicki Minaj wearing them.

It is against this backdrop that this book assessed Africa's soft power capacity by drawing attention to how the regional powers on the continent - Nigeria, South Africa, Kenya, and Egypt - have exercised their soft power to achieve their set goals. Like other states around the world, these countries confront several challenges in the exercise of their soft power. However, they all wield their soft power derived from diverse sources to varying degrees.

Given that the concept of soft power was developed by an American Political Scientist, Joseph Nye, it is no surprise that his conceptualisation of the term is biased toward the United States' political system, domestic politics, and foreign policy. Hence, the immediate task of this book was to de-Americanise and Africanise the concept. In de-Americanising the term, the book drew attention to the soft power resources of non-Western states, specifically the BRIC countries. As I argued, the media has been a fundamental instrument in showcasing the narratives of these states. Media outlets including Qatar's Al Jazeera, Russia's Russia Today, China's CGTN, and India's NDTV have been critical in challenging the stances taken by the Western media, especially CNN's, the BBC's, and France 24's positions on global issues. Non-Western media organisations have also been vocal in representing the voice of the South and being critical of the Western media's often un-analytical portrayal of the global South. This has improved the image of the Southern countries and provided the fillip for states like Russia, China, and India to exercise their soft power.

Beyond the major sources of soft power identified by Nye, China's power of attraction includes trade, the state's role in international organisations, and aid and investment, as well as an alternative development model (the Beijing Consensus). Russia draws its soft power from its sovereign democracy (as an alternative to liberal democracy), natural resources, especially oil and gas, and language (Russian is the dominant language in the CIS states). India's soft power is derived from its large diaspora, historical links with states such as Iran, South Africa, and South East Asian states, Buddhism, and yoga. Brazil's pacifist tradition, success in football tournaments, and the influence of its soccer players are germane in this regard. It is thus clear that these states, whose domestic contexts differ from those of the West, derive some of their soft power from sources that 
are not identified by Nye. In the African context, which is the focus of this book, African philosophies exemplified by Nigeria's Omolúwàbi, South Africa's Ubuntu, Kenya's Harambee, and Egypt's Pharaonism fit this context.

The Omolúwàbi (the epitome of good character) philosophy presents a potential soft power resource for Nigeria. Were it to be imbibed across the globe, it could transform domestic socio-economic circumstances and political behaviour, as well as international relations in such a way that individuals and states let go of individual, narrow interests in favour of collective goods. Coupled with its strong emphasis on morality, Omolúwàbi contrasts the realist paradigm that emphasises narrow interests and disregards morality. Nigeria's most obvious soft power is arguably Nollywood, which has taken the world by storm, evident in its outstripping Hollywood as the second largest producer of movies, its displacement of Hollywood, Bollywood, and producers across Africa in terms of local content, and its reach in Africa, the Caribbean, the Americas and to a lesser extent some parts of Europe. Nollywood has thus made inroads in challenging the negative stereotypes that Nigerians are associated with including corruption, terrorism, Internet scams, and human and drug trafficking; and has made many Nigerian celebrities famous across the globe. Beyond its entertainment value, it serves as a veritable tool to promote Nigeria's foreign policy of economic, cultural, and citizen diplomacy. However, it still needs to do more in providing a counter narrative to anti-Nigerian sentiment across the globe that has resulted in the imprisonment, deportation, and killing of Nigerians.

Abuja has also exercised soft power in the area of democracy promotion in states such as Sierra Leone, São Tomé and Príncipe, the Gambia, Togo, and Liberia. Although the country was successful in these cases, it lacks moral authority to promote democracy in light of its domestic democracy deficit. Nigeria projects the image of a peacemaker on the continent due to peacemaking and peacekeeping efforts such as in Liberia and Sierra Leone. However, its struggle against a domestic uprising in the form of Boko Haram has challenged its military capacity and its image as a peacemaker in Africa. Other sources of Nigeria's soft power include its aid and multilateralism. Despite this soft power reservoir, Nigeria remains a potential soft power state as there is a wide gap between its soft power resources and actual influence.

South Africa is arguably the quintessential soft power state on the continent. Its philosophy of Ubuntu encapsulates community as opposed to individualism, as well as humanness, dignity, harmony, caring, and forgiveness. These are clearly important attributes in a "post-truth" world order increasingly characterised by immorality. In its engagement with the world, South Africa has sought to promote the philosophy and principles of Ubuntu that characterised its celebrated political transition. Its liberal constitution is another important source of Pretoria's soft power as it has received global accolades and provides an important template for other states in relation to constitutionalism. South Africa also boasts of charismatic political leaders. The larger than life character of Nelson Mandela was a significant soft power booster, evident in his global influence and recognition as a symbol of emancipation and reconciliation. Others influences, such as 
those of Steve Biko and Thabo Mbeki, are also notable. While Biko was and remains associated with Black Consciousness, Mbeki symbolises African Renaissance.

Like Nigeria, South Africa is a major peacemaker on the continent, evident in its missions in conflict zones such as Burundi, the DRC, the CAR, and Zimbabwe. Its identity as an African representative finds practical expression in its role as Africa's sole member of BRICS, IBSA, and the G20. South Africa is the most important player in its sub-regional organisations including SADC and the SACU. Pretoria is the pathfinder of APRM and NEPAD and a major player in the AU. Beyond the continent, South Africa has played important roles in the UN, the 1995 extension of the Nuclear Non-Proliferation Treaty, the 1997 Ottawa Process on the banning of land mines, and the 1998 adoption of the Rome Statute. However, its soft power has declined, particularly since the Zuma administration. This is the result of domestic constraints including: high levels of inequality, poverty, and unemployment; incessant service delivery protests, and political corruption. The contradictions of xenophobia and double standards on human rights are equally germane in this regard.

Egypt's Pharaonism presents a philosophy that challenges false Western descriptions of the country's past by highlighting the success of Egypt's ancient civilisation and the state's exceptionalism vis-à-vis other Middle Eastern and Arab states. This philosophy is critical in portraying Egypt in a positive light, thereby reinforcing its soft power. Egypt's Pan-Arabism was and remains the dominant version in the region despite Cairo's decline and the rise of states such as Turkey and Iran to regional powerhood. Until the Arab Spring, which led to the removal of Hosni Mubarak from power in 2011, Egypt was the most significant state in relation to the stability of the Middle East particularly with regard to the Israeli-Palestinian conflict. Mohammed Salah and other key Egyptian entertainment artists continue to display celebrity diplomacy by promoting Islam abroad. Cairo and Alexandria are entertainment hubs, and Egyptian movies and music are the dominant entertainment in the region. This enhances Egypt's cultural and economic diplomacy. Egypt's soft power has, however, been undermined by political instability and the economic challenges that the country has witnessed in the post-Arab Spring period, resulting in the decline of the state's geo-political influence.

Kenya's Harambee, which encourages communal mobilisation of resources through self-help systems to achieve common goals, serves as a potential soft power resource. In an era characterised by increasing over-reliance on government for the provision of public goods, the Harambee philosophy provides an alternative method, particularly given declining government revenue across the globe and the incapacity of many states to provide essential services. The success of Kenyan athletes and the tourist attractions across the country that draw tourists from around the world each year are two key sources of Nairobi's soft power. The display of the country's flag and singing of its national anthem each time an athlete wins a medal in international tournaments provide instant global visibility for the country. Tourist sites such as the Nairobi National Park and Mount 
Kenya, and cultural festivals like the Rusinga Cultural Festival and Maralal Camel Derby enhance the country's cultural and economic diplomacy and contribute significantly to national income.

Kenya's efforts towards regional organisation in its sub-region are born out of the fact that it has the largest seaport in East Africa (Mombasa) and is strategically located as a point of access to contiguous neighbours like Burundi, the DRC, Rwanda, South Sudan, and Uganda. Nairobi therefore takes the EAC seriously as it provides an avenue to promote its economic diplomacy in the subregion where it is the largest economy. This translates to exercising soft power. Nevertheless, there are several obstacles to Kenya's soft power including political corruption, ethnicity, perpetual electoral violence, and the tussle with the ICC.

Despite ubiquitous anti-African sentiment, this book has shown that African states have impressive soft power sources. While some are well developed, others remain potential resources. The extent to which Africa will be able to counteract global Afrophobia will depend on the degree to which the regional powers of Nigeria, South Africa, Kenya, and Egypt and other key states like Angola, Ethiopia, Morocco, and Algeria, are able to harness their soft power capabilities to shape global perceptions of the continent. 


\section{Bibliography}

Abdel-Wahed, M. (2019). "Egypt: The Importance of 'Soft Power'." 22 March. http://en glish.ahram.org.eg/NewsContentP/44/328683/Analysis/Egypt-The-importance-of-\%E 2\%80\%98soft-power\%E2\%80\%99.aspx.

Aboul-Ela, H. (2010). "Is There an Arab (Yet) in This Field? Postcolonialism, Comparative Literature, and the Middle Eastern Horizon of Said's Discourse Analysis." Modern Fiction Studies 56 (4): 729-750.

Adamson, F. and Tsourapas, G. (2019). "Migration Diplomacy in World Politics." International Studies Perspectives 20 (2) 113-128.

Adebajo, A. (2013). "A Chance for Nigeria and SA to Upstage PaxGallica." Business Day October 15. https://www.businesslive.co.za/bd/opinion/columnists/2013-10-15-a-cha nce-for-nigeria-and-sa-to-upstage-pax-gallica/.

Adebajo, A. (2017). "Nollywood: One of the Few True Representations of 'Global Africa'." 25 May. https://www.iol.co.za/news/opinion/nollywood-one-of-the-fewtrue-representations-of-global-africa-9342934.

Adebanwi, W. (2011). Globally Oriented Citizenship and International Voluntary Service: Interrogating Nigeria's Technical Aid Corps Scheme. Discussion Paper 71. Uppsala: Nordiska Uppsala, Afrikainstitutet.

Adebanwi, W. and Obadare, E. (2011). "When Corruption Fights Back: Democracy and Elite Interests in Nigeria's Anti-Corruption War." The Fournal of Modern African Studies 49 (2): 185-213.

Adesina, O. (2017). "Projecting Nigeria's Soft Power through Culinary Diplomacy." African Fournal for the Psychological Study of Social Issues 20 (1): 140-149.

Africa Policy Institute (2018). "Humanitarian Diplomacy." https://www.africapi.org/ humanitarian-diplomacy/.

Agbaje, A. and Adejumobi, S. (2006). "Do Votes Count? The Travails of Electoral Politics in Nigeria." Africa Development XXXI (3): 25-44.

Agence France-Presse (2019). "Repression Risks Fueling Egypt Instability, Analysts Warn.” 29 September. https://www.voanews.com/africa/repression-risks-fueling-egyp t-instability-analysts-warn.

Akinola, A. (2019). "Nigeria and South Africa in Sub-Regional Peace and Security Agenda: A Comparison." In: Tella, O. (ed.), Nigeria-South Africa Relations and Regional Hegemonic Competence. Cham: Springer, pp. 163-182.

Akinola, A. and Ogunnubi, O. (2020). "Soft Power or Wasteful Entertainment? Interrogating the Prospect of 'Big Brother Naija'." The Round Table, doi:10.1080/ 00358533.2020 .1717088$. 
Akinola, A. and Okeke-Uzodike, U. (2018). "Ubuntu and the Quest for Conflict Resolution in Africa." Journal of Black Studies 49 (2): 91-113.

Akokpari, J. (2018). "Consistency in Inconsistency: South Africa's Foreign Policies in International Organizations." In: Warner, J. and Shaw, T. (eds), African Foreign Policies in International Institutions. New York: Palgrave Macmillan.

Alden, C. and le Pere, G. (2009). "South Africa in Africa: Bound to Lead?" Politikon 36 (1): $145-169$.

Alden, C. and Schoeman, M. (2015). "South Africa's Symbolic Hegemony in Africa." International Politics 52 (2): 239-254.

al-Dosary, S. (2018). "The Soft Power of Mohammed Salah.” Al Arabiya, 27 April. https:// english.alarabiya.net/en/views/news/middle-east/2018/04/27/The-soft-power-of-Mo hamed-Salah.html.

Aljazeera (2016). "The Power of Egyptian Cinema - Online." Aljazeera, 24 June. https://www. aljazeera.com/news/2016/06/power-egyptian-cinema-online-160612084145507.html.

Alli, W. (2012). The Role of Nigeria in Regional Security Policy. Abuja: Friedrich-Ebert-Stiftung, Regional Office.

Allison, L. and Monnington, T. (2005). "Sport, Prestige and International Relations." In: Allison, L. (ed.), The Global Politics of Sport: The Role of Global Institutions in Sport. London: Routledge, pp. 5-23.

Allison, S. (2016). "Imposing, Aggressive and Unwilling to Listen: How South Africans Are Perceived in Africa." Daily Maverick, March 17. http://www.dailymaverick.co.za/a rticle/2016-2003-17-imposing-aggressive-and-unwilling-to-listen-how-south-africans-ar e-perceived-in-africa/\#.VxiD_01DGUk.

Alrababa'h, A., Marble, W., Mousa, S., and Siegel, A. (2019). "Can Exposure to Celebrities Reduce Prejudice? The Effect of Mohamed Salah on Islamophobic Behaviors and Attitudes." Immigration Policy Lab Working Paper No. 19-04.

Aluko, O. and Ogunnubi, O. (2018). "Nigeria's Soft Power and Economic Diplomacy in Africa." Fournal of African Foreign Affairs 5 (2): 189-206.

Aly, E. (2016). "Is Egypt Still the 'Hollywood of the Middle East'?" The Caravan, 25 March. https://www.auccaravan.com/?p=3571.

Al-Youm, A. (2018). "Egypt Calls for Allocating 2 African Seats in UN Security Council." Egypt Independent, 22 November. https://egyptindependent.com/egypt-calls-for-alloca ting-2-african-seats-in-un-security-council/.

Amao, O. and Maiangwa, B. (2017). "Has the Giant gone to sleep? Re-assessing Nigeria's response to the Liberian Civil War (1990-1997) and the Boko Haram insurgency (2009-2015)." African Studies 76 (1): 22-43.

American Chamber of Commerce in Egypt (2019). "Egypt's Soft Power: A Force to Be Reckoned With." https://www.amcham.org.eg/publications/business-monthly/issues/ 287/November-2019/3902/egypts-soft-power-a-force-to-be-reckoned-with.

April, Y. (2009). "Assessing South Africa's Strategic Options of Soft Power Application through Civic Interest Groups." African Fournal of Conflict Resolution 9 (1): 123-144.

Bach, D. (2007). "Nigeria's 'Manifest Destiny' in West Africa: Dominance without Power." Africa Spectrum 42 (2): 301-321.

Bahgat, G. (2007). "Nuclear Proliferation: Egypt." Middle Eastern Studies 43 (3): 409-421.

Bakare, O. and Read, R. (2019). "The Nigerian-Commonwealth and UN relations: Nigeria, from Pariah state to exporter of democracy since 1999." Cogent Social Sciences 5 (1): 1-13.

Ballerini, F. (2020). Is Brazil's Soft Power Under Threat? Fair Observer, 21 February. https: //www.fairobserver.com/region/latin_america/brazil-football-carnival-culture-soft-pow er-jair-bolsonaro-news-15521/. 
Bamidele, O. (2015). "Nigeria: A Quest for a Permanent Seat in the United Nations Security Council." Conflict Studies Quarterly 13: 41-57.

Barnard, I. (2006). "The Language of Multiculturalism in South African Soaps and Sitcoms." Journal of Multicultural Discourses 1 (1): 39-59.

BBC News (2010). "How Nigeria Has Affected the Rest of Africa.” September 30. http:// www.bbc.co.uk/news/world-africa-11429067.

BBC News (2016). "David Cameron calls Nigeria and Afghanistan 'Fantastically Corrupt'." May 10. https://www.bbc.com/news/uk-politics-36260193.

BBC News (2017). “Cameroon Forces 'Kill 97 Nigerian Fishermen' in Bakassi." July 14. http://www.bbc.com/news/world-africa-40607306.

BBC News (2019). "Letter from Africa: Why Nigeria's Internet Scammers are 'role models"." https://www.bbc.com/news/world-africa-49759392.

Bel-Air, F. (2016). Migration Profile: Egypt. Migration Policy Centre. Florence: European University Institute.

Bertonha, J. (2010). "Brazil: An Emerging Military Power? The Problem of the Use of Force in Brazilian International Relations in the 21st Century." Rev. Bras. Polit. Int. 53 (2): 107-124.

Bhagawati, J. (2018). China's Growing Influence in Africa: Lessons for India. New Delhi: National Maritime Foundation.

Bird, B. (2019). "How Mohamed Salah Inspired Me to Become a Muslim." The Guardian, 3 October. https://www.theguardian.com/football/2019/oct/03/mohamed-salah-insp ired-me-become-muslim-liverpool-islam.

Blarel, N. (2012). India: The Next Superpower? India's Soft Power: From Potential to Reality? IDEAS reports - special reports LSE IDEAS. London: London School of Economics and Political Science.

Blaydes, L. (2019). "Challenges to Stability in Egypt." 22 April. https://www.hoover.org/ research/challenges-stability-egypt.

Bloomberg (2015). "Bloomberg Markets 50 Most Influential." http://www.bloomberg. com/features/2015-markets-most-influential/\#intro. Accessed 15 February 2016.

Bodomo, A. (2009). "Africa-China Relations: Symmetry, Soft Power and South Africa." The China Review 9 (2): 169-178.

Brand Africa (2015). Brand Africa 100: Africa's Best Brands. Gauteng: Brand Africa.

Brand Africa (2020). "Brand Africa 100." https://www.brandafrica.net/Rankings.aspx.

Brand Finance (2020). Global Soft Power Index 2020. London: Brand Finance.

Brand South Africa (2010). "Zuma: SA's Most Important Year." http://www.brandsoutha frica.com/governance/developmentnews/zuma-new-year-message.

The Brenthurst Foundation (2020). How to Turn Crisis into Opportunity After Covid-19: Choices for a Better South African Future. Discussion Paper 3. Johannesburg: The Brenthurst Foundation.

Burgess, S. (2020). "The Foreign Policies of Large Democratizing African States: South Africa and Nigeria." Journal of European, Middle Eastern, E African Affairs 2 (1): 98-129.

Busolo, M. (2016). The Role of Sports Diplomacy in African International Relations: The Case of Kenya. Nairobi: University of Nairobi.

Byron, K. and Chepyator-Thomson, J. (2015). "Sports Policy in Kenya: Deconstruction of Colonial and Post-colonial Conditions." International Fournal of Sport Policy and Politics 7 (2): 301-313.

Calland, R. and Recht, S. (2015). "Institutional Renaissance or Populist Fandango? The Impact of the Economic Freedom Fighters on South Africa's Parliament." Übersee VR $\ddot{U}$ 48 (3): 304-328. 
Campbell, H. (2017). "The United States and Security in Africa: The Impact of the Military Management of the International System.” Africa Development XLII (3): 45-71.

Campbell, J. (2018). "Nigerians' Growing Cultural Influence Around the World." 7 November. https://www.cfr.org/blog/nigerians-growing-cultural-influence-around-world.

Campbell, J. (2019). "U.S. Arrests Celebrated Nigerian Entrepreneur for Fraud. Council on Foreign Relations." https://www.cfr.org/blog/us-arrests-celebrated-nigerian-entrep reneur-fraud.

Campbell, J. (2020). "Borno Governor Survives Boko Haram Attack in Nigeria." Council on Foreign Relations, 5 August. https://www.cfr.org/blog/borno-governor-survives-boko-ha ram-attack-nigeria.

Carr, H. E. (1946). The Twenty Years' Crisis, 1919-1939: An Introduction to the Study of International Relations. New York: Harper and Row.

Chatterjee, S. (2018). "Kenya - Overcoming Rivalry \& Conflict through Cultural Diplomacy." Inter Press Service Newes Agency. April 27. http://www.ipsnews.net/2018/04/kenya -overcoming-rivalry-conflict-cultural-diplomacy/.

Cheeseman, N., Kanyinga, K., Lynch, G., Ruteere, M., and Willis, J. (2019). "Kenya's 2017 Elections: Winner-takes-all Politics as Usual?" Gournal of Eastern African Studies 13 (2): 215-234.

Chege, M. (2008). "Kenya: Back from the Brink?” Fournal of Democracy 19 (4): 125-139.

Chege, M. (2018). "Kenya's Electoral Misfire.” Journal of Democracy 29 (2): 158-172.

Chepkwony, K. (2008). The Role of Harambee in Socio-Economic Development in Kenya: A Case of the Education Sector. Investment Glimate and Business Environment Research Fund. Report No. 16/12.

Chetty, D. (2009). "An Harambee Theory of Rhetoric in Social Action: Persuasion, Religious Identity \& Recognition in Sudan." Alternation 16 (Special Edition): 301-330.

Chieni, S. (1998). The Harambee Movement in Kenya: The Role Played by Kenyans and the Government in the Provision of Education and other Social Services. Moi University.

China Power (2017). "Is China Both a Source and Hub for International Students?" China Power. 26 September. https://chinapower.csis.org/china-international-students/.

Chiroro, B. (2012). South Africa: Optimising the Currency of Soft Power in the International Arena. Briefing No. 79. Pretoria: Africa Institute of South Africa.

Cho, S., Connors, E., Fatima, F., and Yalim, U. (2015). Preventing Post-Election Violence Based on the Kenyan Experience. California: Stanford University Press.

Cho, Y. and Jeong, J. (2008). "China's Soft Power: Discussions, Resources, and Prospects." Asian Survey 48 (3): 453-472.

Chomsky, N. and Achcar, G. (2007). Perilous Power: The Middle East and US Foreign Policy. Oxon: Routledge.

Cloete, N., Sheppard, C., and Bailey, T. (2015). "South Africa as a PhD Hub in Africa?" In: Cloete, N., Sheppard, C., and Bailey, T. (eds), Knowledge Production and Contradictory Functions African Higher Education. Cape Town: African Minds, pp. 75-108.

CNBC (2019). "The US-China Trade Rivalry is Underway in Africa, and Washington Is Playing Catch-up." https://www.cnbc.com/2019/10/09/the-us-china-trade-rivalry-i s-underway-in-africa.html.

CNBC Africa (2014). "The Changing Global Perception of S. Africa." CNBC Africa, 20 March. www.cnbcafrica.com/news/southern-africa/2014/03/20/the-changing-globa l-perception-of-safrica/.

Coaston, J. and O’Donnell, B. (2016). "Africa Specific: Jidenna, Turning up the Volume on Afrobeats." MTV newes 10 May. http://www.mtv.com/news/2940072/african-speci fic-jidenna-turning-up-the-volume-on-afrobeats/. 
Cold-Ravnkilde, S. (2019). "Contested Norms in Fragmented Institutions: Gender Equality in South Africa's Development Cooperation." Progress in Development Studies 19 (3): 211-231.

Colla, E. (2007). Egyptology, Egyptomania, Egyptian Modernity. Durham and London: Duke University Press.

Council on Foreign Relations (2018). "China's Big Bet on Soft Power.” https://www.cfr. org/backgrounder/chinas-big-bet-soft-power.

Council on Foreign Relations (2020). "Instability in Egypt." https://www.cfr.org/globa l-conflict-tracker/conflict/instability-egypt.

CRAI (Citizenship Rights in Africa Initiative) (2009). "Tolerating Intolerance: Xenophobic Violence in South Africa." http://citizenshiprightsinafrica.org/docs/CRAI SAReportFINAL.pdf

Ćwiek-Karpowicz, J. (2012). "Limits to Russian Soft Power in the Post-Soviet Area." DGA Panalyse 8.

Cybermetrics (2020). "Ranking Web of Universities." https://www.webometrics.info/en/ Ranking_africa.

Da Cruz, J. and Stephens, L. (2010). "The U.S. Africa Command (AFRICOM): Building Partnership or Neo-colonialism." Fournal of Third World Studies 27 (2): 193-213.

Dauda, B. (2017). "African Humanism and Ethics: The Cases of Ubuntu and Omolúwàbí." In: Afolaya, A., and Falola, T. (eds), The Palgrave Handbook of African Philosophy. London: Palgrave, pp. 475-492.

Dawood, I. (2012). "The Engagement of Highly Skilled Egyptian Migrants in OECD Countries." The Center for Migration and Refugee Studies, American University in Cairo.

De Bel-Air, F. (2016). Migration Profile: Egypt. Florence: European University Institute.

de Haas, H. (2007). North African Migration Systems: Evolution, Transformations and Development Linkages. Oxford: International Migration Institute, University of Oxford.

Department for International Development (2010). Elections in Kenya in 2007. London: Department for International Development.

Department of International Relations and Cooperation (DIRCO) (2019). "Media Briefing on the Ministerial Panel Report 17 April." Pretoria: DIRCO.

De Lima, M. and Hirst, M. (2006). "Brazil as an Intermediate State and Regional Power: Action, Choice and Responsibilities." International Affairs 82 (1): 21-40.

Ding, S. (2010). "Analyzing Rising Power from the Perspective of Soft Power: a new look at China's rise to the status quo power." Journal of Contemporary China 19 (64): 255-272.

Diop, C. (1970). "The Birth of the 'Negro Myth" In: Markovitz, I., and Markovitz, R. (eds), African Politics and Society: Basic Issues and Problems of Government and Development. New York: Free Press.

Directorate of Technical Aid Corps (2020). "Goals and Objectives of the Technical Aid Corps Scheme." http://www.dtac.gov.ng/DTAC/dtac/aboutDTAC\#first.

Dowse, S. (2011). Power Play: International Politics, Germany, South Africa and the FIFA World Cup. Occasional Paper No. 82. Johannesburg: South African Institute of International Affairs.

DW (2020). "South Africa's Double Blow: Corruption and the Coronavirus." https://www. dw.com/en/south-africas-double-blow-corruption-and-the-coronavirus/a-54423065.

DW (2020). "Egypt's President El-Sissi's One Year as Head of The African Union." 7 February. https://www.dw.com/en/egypts-president-el-sissis-one-year-as-head-of-the-a frican-union/a-52296736.

Ebegbulem, J. (2011). "Nigeria and Conflict Resolution in Africa: The Darfur Experience." Civilizar 11 (21): 69-76. 
The Economist (2019). "Egypt Is Reforming Its Economy, But Poverty Is Rising." 8 August. https://www.economist.com/middle-east-and-africa/2019/08/08/egypt-is-reforming-it s-economy-but-poverty-is-rising.

The Economist Intelligent Unit (2020). Democracy Index 2019: A Year of Democratic Setbacks and Popular Protest. London: The Economist Intelligent Unit.

Egwemi, V. (2010). "Managing Nigeria's Image Crisis: Akunyili's Rebranding Programme to the Rescue (?)" Current Research Fournal of Economic Theory 2 (3): 131-135.

Egypt Today (2018). "Foreign Ministry Spokesman Congratulates Mohamed Salah." Egypt Today, 23 April. https://www.egypttoday.com/Article/8/48460/Foreign-Ministry-sp okesman-congratulates-Mohamed-Salah.

El Banhawy, Y. (2019). "Why Is the Egyptian State Monopolizing the Entertainment Industry?"24 June. https://www.opendemocracy.net/en/north-africa-west-asia/why-e gyptian-state-monopolizing-entertainment-industry/.

Elder, C., Stigant, S., and Claes, J. (2014). Elections and Violent Conflict in Kenya: Making Prevention Stick. Washington, DC: United States Institute of Peace.

El-Mahdi, R. (2009). "Enough! Egypt's Quest for Democracy." Comparative Political Studies 42 (8): 1011-1039.

El-Menawy, A. (2018). "Egypt Determined to Use Culture to Restore Its Soft Power." The Daily Observer. 5 July. http://www.observerbd.com/details.php?id=146213.

El Rehim, A. (2017). "The Potential of Egypt's Soft Power Post Arab Spring." Geopolitics under Globalization 1 (1): 12-16.

El Safty, A. (2020). "Egypt Beyond Economic Stabilization: The Road to Sustainable Growth." 10 March. http://trendsresearch.org/insight/chep-framework-and-the-cha llenges-facing-egyptian-economy/.

El Sebaie, R. and Mouawad, A. (2014). EU and Egypt 30 th of June Revolts: A Normative Power Lens. Final Search Academic Conference: "How to Strengthen EU-NGs Relationships." Barcelona, 10-11 February 2014.

Emmanuel, K. (2014). Kenya's Regional Relations: Between Principle and Practice. South African Institute of African Affairs. South African Foreign Policy and African Drivers Programme. Policy Briefing 113.

Emmanuel, K. (2016). Kenya's Regional Diplomacy: Peripheral or Adaptive Pragmatism? South African Institute of International Affairs Occasional Paper 248.

Ernst and Young (2015). Cultural Times: The First Global Map of Cultural and Creative Industries. London: Ernst and Young.

Ettang, D. and Leeke, N. (2019). "Africa's Emerging Giants and the Drug Scourge: Exploring a Nigeria-South African Bilateral Partnership." In: Tella, O. (ed.), Nigeria-South Africa Relations and Regional Hegemonic Competence. Cham: Springer.

Evoy, C. (2013). Shifting Priorities: Kenya's Changing Approaches to Peacebuilding and Peacemaking. Norwegian Peacebuilding Resource Centre.

Ezenagu, N. and Enohuean, E. (2017). "Public Perception of Boko Haram Insurgency on Destination Image and Tourist Flow in Northern Nigeria." African Fournal of Hospitality, Tourism and Leisure 6 (4): 1-14.

Fanack (2012). "Egyptian Films." 12 November. https://fanack.com/egypt/society-media -culture/culture/film/.

Fanack (2020). "Economy of Egypt." https://fanack.com/egypt/economy/.

Fawole, A. (2003). Nigeria's External Relations and Foreign Policy under Military Rule, 1966-1999. Ile-Ife: Obafemi Awolowo University Press.

February, J. (2019). State Capture: An Entirely New Type of Corruption. Pretoria: ISS. 
Ferguson, N. (2009). "Think Again: Power.” Foreign Policy, 3 November. https://foreignp olicy.com/2009/11/03/think-again-power/.

Fjelde, H. and Höglund, K. (2018). "Ethnic Politics and Elites Competition: The Roots of Electoral Violence in Africa." In: Kovacs, M. and Bjarnesen, J. (eds), Violence in African Elections: Between Democracy and Big Man Politics. London: Zed Books, pp. 27-46.

Forbes (2020). "World's Billionaires List: The Richest in 2020." https://www.forbes.com/ billionaires/.

France 24 (2017). "Nigerian Artists Davido, Wizkid Taking Afrobeats to Next Level." 9 November. https://www.france24.com/en/20171109-nigerian-artists-davido-wizkid-ta king-afrobeats-next-level.

France 24 (2020). "Boko Haram Kills Almost 100 Soldiers in Seven-Hour Attack in Chad." https://www.france24.com/en/20200325-boko-haram-kills-almost-100-soldier s-in-a-seven-hour-attack-in-chad.

France 24 (2020). "Egypt Leverages 'Soft Power' Through Medical Aid in Pandemic.” 14 May. https://www.france24.com/en/20200514-egypt-leverages-soft-power-through-m edical-aid-in-pandemic.

Frazer, G. (2018). "America's Petty Policy on Used Clothes for Africa." 17 April. The Conversation. https://theconversation.com/americas-petty-policy-on-used-clothes-for-a frica-95132.

Freedom House (2020). "Freedom in the World 2020." https://freedomhouse.org/coun tries/freedom-world/scores.

Freeman, K. (2012). "Sport as Swaggering: Utilizing Sport as Soft Power." Sport in Society 15 (9): 1260-1274.

The Fund for Peace (2020). Fragile States Index Annual Report 2020. Washington, DC: The Fund for Peace.

Gallup (2010). “Americans See Slight Improvement in U.S. Global Image.” https://news. gallup.com/poll/125858/americans-slight-improvement-global-image.aspx.

Gallup (2017). "New Index Shows Least-, Most-Accepting Countries for Migrants." http s://news.gallup.com/poll/216377/new-index-shows-least-accepting-countries-migrants. aspx.

Geldenhuys, D. (2008). "The Idea-Driven Foreign Policy of a Regional Power: The Case of South Africa." In: Regional Powers Network (RPN) conference, German Institute of Global and Area Studies (GIGA), Hamburg, Germany, 15-16 September.

Ghafar, A. (2018). "Egypt's Long-term Stability and the Role of the European Union." 1 March. https://www.brookings.edu/blog/order-from-chaos/2018/03/01/egypts-longterm-stability-and-the-role-of-the-european-union/.

Gill, B. and Huang, Y. (2006). "Sources and Limits of Chinese Soft Power." Survival: Global Politics and Strategy 48 (2): 17-36.

Giorgis, H. (2019). "The 'African Giant' Challenging Musical Boundaries." The Atlantic. https://www.theatlantic.com/entertainment/archive/2019/07/burna-boy-african-gian t-bombastic-nigerian-pop/594610/.

Global Fire Power (2020). "2020 Military Strength Ranking." https://www.globalfirep ower.com/.

Global Tourism Forum (2020). "Kenya Tourism Sector Performance in 2019." 16 January. https://www.globaltourismforum.org/blog/2020/01/16/kenya-tourism-sector-p erformance-in-2019/.

Godfrey, M. and Mutiso, G. (1975). "Economics, Politics and Education: Kenya's Harambee Institutes of Technology." Institute of Development Studies Bulletin 6 (3): 85-94. 
Grafton, R., Wyrwoll, P., White, G., and Allendes, D. (2014). Global Water: Issues and Insights. Canberra: ANU Press, The Australian National University.

Graham, S. (2008). "Gold Star or Bottom of the Class: Is South Africa a Good International Citizen?" South African Fournal of International Affairs 15 (1): 87-97.

Gramsci, A. (1971). Selections from the Prison Notebooks. London: Lawrence and Wishart.

Grix, J. and Lee, D. (2013). "Soft Power, Sports Mega-Events and Emerging States: The Lure of The Politics Of Attraction." Global Society 27 (4): 521-536.

Habib, A. (2009). "South Africa's Foreign Policy: Hegemonic Aspirations, Neoliberal Orientations and Global Transformation." South African Fournal of International Affairs 16 (2): 143-159.

Hairsine, K. (2019). "Why Is Homosexuality Still Taboo in Many African Countries?”4 December. https://www.dw.com/en/why-is-homosexuality-still-taboo-in-many-africa n-countries/a-51528737.

Hamed, Y. (2019). “Egypt’s Economy Isn’t Booming. It's Collapsing.” Foreign Policy 7 June. https://foreignpolicy.com/2019/06/07/egypts-economy-isnt-booming-its-collapsing-im f-abdel-fattah-sisi-poverty/.

Hamman, S. and Omojuwa, K. (2013). "The Role of Nigeria in Peacekeeping Operations from 1960 to 2013." Mediterranean Fournal of Social Sciences 4 (16): 27-32.

Hamzawy, A. (2010). "The Nile in Crisis: The End of Egypt's Soft Power." Carnegie Endowment for International Peace 28 May. https://carnegieendowment.org/2010/05/28/ nile-in-crisis-end-of-egypt-s-soft-power-pub-40938.

Hanauer, L. and Morris, L. (2014). Chinese Engagement in Africa Drivers, Reactions, and Implications for U.S. Policy. Washington, DC: Rand Corporation.

Hansen, S. (2020). "What Kenya Stands to Lose and Gain By Withdrawing From Somalia." The Conversation, 30 April. https://theconversation.com/what-kenya-stands-to-lo se-and-gain-by-withdrawing-from-somalia-133640.

Hardy, S. (2015). "Soft Power South African Style." http://chimurengachronic.co.za/ soft-powersouth-african-style/.

Harrington, J. and Manji, A. (2012). "Satire and the Politics of Corruption in Kenya." Social \& Legal Studies 22 (1): 3-23.

Hartmann, C. (2017). "ECOWAS and the Restoration of Democracy in The Gambia." Africa Spectrum 52 (1) 85-99.

Hengari, A. (2018). South Africa's Hazardous Ballet with Human Rights Diplomacy. South African Institute of International Affairs. Policy Insights 53.

Heungoup, H. (2016). "Q\&A: Boko Haram in Cameroon." International Crisis Group, 6 April. https://www.crisisgroup.org/africa/central-africa/cameroon/q-boko-haram-cam eroon.

Hill, F. (2006). "Moscow Discovers Soft Power." Current History 105 (693): 341-347.

Hinnebusch, R. (2013). "Failed Regional Hegemons: The Case of the Middle East's Regional Powers." Fournal of Diplomacy \& International Relations 14 (11): 75-88.

Hove, M. and Ndawana, E. (2017). "Regime-Change Agenda: The Egyptian Experience from 2011 to 2015." Contemporary Arab Affairs 10 (1): 32-50.

Howell, J. (1968). "An Analysis of Kenyan Foreign Policy." The Fournal of Modern African Studies 6 (1): 29-48.

Huang, Y. and Ding, S. (2006). "Dragon's Underbelly: An Analysis of China's Soft Power." East Asia 23 (4): 22-44.

Hulse, M. (2016). Regional Powers and Leadership in Regional Institutions: Nigeria in ECOWAS and South Africa in SADC. Kolleg-Forschergruppe (KFG) Working Paper Series. Berlin: Kolleg-Forschergruppe. 
Human Rights Watch (2011). Kenya and the International Criminal Court Questions and Answers. New York: Human Rights Watch.

Human Rights Watch (2015). World Report: Events of 2014. New York: Human Rights Watch.

Human Rights Watch (2018). "Egypt: Campaign to Crush Artistic Freedom.” 16 August. https://www.hrw.org/news/2018/08/16/egypt-campaign-crush-artistic-freedom.

Human Rights Watch (2019). "South Africa: Punish Xenophobic Violence.” 13 September. https://www.hrw.org/news/2019/09/13/south-africa-punish-xenophobic-violence.

Idowu, A. and Ogunnubi, O. (2018). "Nigeria's Soft Power and Economic Diplomacy in Africa." Fournal of African Foreign Affairs 5 (2): 189-206.

Independent (2020). "Instagram Influencer 'Hushpuppi' Arrested Amid Claims of $\AA^{350 m i l-}$ lion Global Cyberscam." 29 June. https://www.independent.co.uk/news/world/m iddle-east/hushpuppi-instagram-news-arrested-cyberscam-350-million-a9590826.html.

Indian Council for Cultural Relations (2019). "List of ICGR Operational Chairs." http s://www.iccr.gov.in/online-form/chairs/introduction.

Institute for Economics and Peace (2019). "Global Terrorism Index 2019: Measuring the Impact of Terrorism." http://visionofhumanity.org/reports.

Institute for Economics and Peace (2020). Global Peace Index 2020: Measuring Peace in a Complex World. Sydney: Institute for Economics and Peace.

International Crisis Group (2012). The Kenyan Military Intervention in Somalia. Africa Report no. 184. Brussels: International Crisis Group.

International Crisis Group (2017). "Fighting Boko Haram in Chad: Beyond Military Measures." 8 March. Report No. 246. https://www.crisisgroup.org/africa/central-a frica/chad/246-fighting-boko-haram-chad-beyond-military-measures.

International Narcotics Control Board (INCB) (2017). Report of the International Narcotics Control Board for 2017. Vienna: International Narcotics Control Board.

International Narcotics Control Board (INCB) (2019). Report of the International Narcotics Control Board for 2019. Vienna: International Narcotics Control Board.

International Organisation for Migration (2010). A Study on the Dynamics of the Egyptian Diaspora: Strengthening Development Linkages. Cairo: International Organization for Migration.

International Trade Centre (2016). Cotton, Textile and Apparel Sector Investment Profile: Kenya. Geneva: International Trade Centre.

IOL (2019). "Tanzania Urges South Africa to Increase Investments: Presidency." 16 August. https://www.iol.co.za/business-report/international/tanzania-urges-south-a frica-to-increase-investments-presidency-30866672.

Ives, S. (2007). "Mediating the Neoliberal Nation: Television in Post-Apartheid South Africa." ACME: An International E-fournal for Critical Geographies 6 (1): 153-173.

Jaishankar, D. (2018). "India Rising: Soft Power and the World's Largest Democracy." https://www.brookings.edu/opinions/india-rising-soft-power-and-the-worlds-largest-de mocracy/.

Jewell, G. (2019). "iROKOtv: Delivering Nollywood Content to the World." WIPO Magazine. https://www.wipo.int/wipo_magazine/en/2017/05/article_0002.html.

Jinadu, A. (2016). "South-South Cooperation in the African Region: Case Study of Nigeria's Technical Aid Corps (TAC)." Fournal of International Politics and Development $14(1): 1-39$.

Johnson, I. (2016). "Beyond Orthodox Strategies: Managing Conflicts and Sustaining Peace Through Communal Ethics, Traditional Values and Methods in Africa." Studies in Sociology of Science 7 (4): 26-33. 
Kagwanja, P. (2016). "Economic Diplomacy Transforming Kenya into a Global Soft Power." Daily Nation, September 4. https://www.nation.co.ke/oped/opinion/Economic -diplomacy-transforming-Kenya-into-a-global-soft-power/440808-3368446-1407fhl/ind ex.html.

Kagwanja, P. and Southall, R. (2009). "Introduction: Kenya - A Democracy in Retreat?" Fournal of Contemporary African Studies 27 (3): 259-277.

Kazeem, Y. (2018). "The Global Rise of Nigeria's Afrobeats Music Could Help Fix the Local Industry's Problems.” Quartz Newes, 4 October. https://qz.com/africa/1411996/ the-global-rise-of-nigerias-afrobeats-music-could-help-fix-the-local-industrys-problems/ .

Kendall, S. (2014). "UhuRuto' and Other Leviathans: The International Criminal Court and the Kenyan Political Order." African Fournal of Legal Studies 7: 399-427.

Kenya Human Rights Commission (2018). Exposing the Governance Conundrum in Kenya: Deep State, Mega-Corruption and Stalled Electoral Reforms. Nairobi: Kenya Human Rights Commission.

Kenya Today (2016). "Breaking: President Kenyatta Makes 69 Foreign Trips in Less than 3 Years." 3 March 2016. https://www.kenya-today.com/politics/breaking-president-ke nyatta-makes-69-foreign-trips-less-3-years-2.

Kenyan Government (2007). Kenya Vision 2030: The Popular Version. Nairobi: Kenyan Government.

Kenyan Government (2018). Kenya Vision 2030: Marking Ten Years of Progress (2008-2018). Nairobi: Kenyan Government.

The Kenyan Textile and Fashion Industry Report (2016). The Kenyan Textile and Fashion Industry: The role of fashion designers and small tailors in the fibre to fashion value chain. Nairobi: Hivos East Africa Office.

Khadiagala, G. and Nganje, F. (2016). "The Evolution of South Africa's Democracy Promotion in Africa: From Idealism to Pragmatism." Cambridge Review of International Affairs 29 (4): 1561-1581.

Khumalo, T. (2019). "South Africa Deploys Envoys in Wake of Xenophobic Attacks." 16 September. https://www.voanews.com/africa/south-africa-deploys-envoys-wake-xenop hobic-attacks.

Krings, M. and Simmert, T. (2020). "African Popular Culture Enters the Global Mainstream." Current History 119 (817): 182-187.

Krippahl, C. (2019). "Xenophobia in South Africa Strains International Relations." DW 3 September. https://www.dw.com/en/xenophobia-in-south-africa-strains-internationa 1-relations/a-50275526.

Kuna, M. (2005). "The Role of Nigeria in Peace Building, Conflict Resolution, and Peacekeeping since 1960." A Paper Presented at the Workshop on Nigeria and the Reform of the United Nations, Organised by the Centre for Democratic Development, Research and Training, Hanwa, Ahmadu Bello University, Zaria.

Kurlantzick, J. (2007). Charm Offensive: How China's Soft Power is Transforming the World. New Haven and London: Yale University Press.

Kwatemba, S. (2008). "Ethnicity and Political Pluralism in Kenya." Journal of African Elections 7 (2): $77-112$.

Lalbahadur, A. (2019). "Xenophobia Erodes South Africa's Leadership Potential.” 27 May. https://saiia.org.za/research/xenophobia-erodes-south-africas-leadership-potential/.

Landsberg, C. (2000). "Promoting Democracy: The Mandela-Mbeki Doctrine." Fournal of Democracy 11 (3): 107-121.

Landsberg, C. (2012). "Afro-Continentalism: Pan-Africanism in Post-Settlement South Africa's Foreign Policy." Journal of Asian and African Studies 47 (4) 436-448. 
Landsberg, C. (2016). Caught between Afro-Southern Solidarism and Liberal Cosmopolitan Values: Four Turning points in South Africa's Human Rights Foreign Policy. Occasional Paper Series. Johannesburg: Friedrich Ebert Stiftung, South Africa.

Langer, C. (2017). "The Informal Colonialism of Egyptology: From the French Expedition to the Security State." In: Woons, M. and Weier, S. (eds), Critical Epistemologies of Global Politics. Bristol: E-International Relations Publishing, pp. 182-202.

Larsen, H. and Sheel, A. (2015). "The Kenyan Runners." Scandinavian Fournal of Medicine and Science in Sports 25 (4): 110-118.

Laruelle, M. (2015). The "Russian World" Russia's Soft Power and Geopolitical Imagination. Washington, DC: Centre on Global Interests.

Leijenaar, A. (2017). "Egypt Renews Its Commitment to Africa: Egypt's Stake in Africa's Peace, Security and Development Is Often Overlooked." 20 March. ISS Today.

le Pere, G. (2017). "Ubuntu as Foreign Policy: The Ambiguities of South Africa's Brand Image and Identity." Strategic Review for Southern Africa 39 (1): 93-115.

le Pere, G. (2014). Critical Themes in South Africa's Foreign Policy: An Overview. Strategic Review for Southern Africa 36 (2): 31-56.

Lietzelman, H. (2014-2015). "Pharaonism: Decolonizing Historical Identity." Prized Writing (46-51).

Long, J., Kanyinga, K., Ferree, K., and Gibson, C. (2013). "Kenya's 2013 Elections: Choosing Peace over Democracy." Journal of Democracy 24 (3): 140-155.

Louw-Vaudran, L. and Diatta, M. (2019). "Can South Africa Repair Its Image Damaged by Xenophobia?"16 September. https://issafrica.org/iss-today/can-south-africa-repa ir-its-image-damaged-by-xenophobia.

Lugano, G. (2017). "Assessing the Acceptance of International Criminal Justice in Kenya." In: Buckley-Zistel, S., Mieth, F., and Papa, M. (eds), After Nuremberg. Exploring Multiple Dimensions of the Acceptance of International Criminal Fustice. Nuremberg: International Nuremberg Principles Academy.

Mabera, F. (2016). "Kenya's Foreign Policy in Context (1963-2015)." South African Fournal of International Affairs 23 (3): 365-384.

Mabera, F. (2017). "The Impact of Xenophobia and Xenophobic Violence on South Africa's Developmental Partnership Agenda." Africa Review 9 (1): 28-42.

Mabera, F. (2018). "South Africa's Profile as Peacekeeper: In Keeping with the Times?" African Security 11 (3): 223-251.

Matilda, O. (2018). "The Impact of Electoral Violence on Economic Development: A Case of Kenya." Journal of Political Science and International Relations 1 (3): 55-71.

Mada Masr (2013). "Egypt Reacts Angrily to South African Criticism." Mada Masr, 31 July. Available at https://www.madamasr.com/en/2013/07/31/news/u/egypt-rea cts-angrily-to-south-african-criticism/.

Madise, D. and Isike, C. (2020). "Ubuntu Diplomacy: Broadening Soft Power in an African Context." Journal of Public Affairs. doi:10.1002/pa.2097.

Mail \& Guardian (2013). "South Africa Is 'Immature', Says Swaziland." Mail \& Guardian, 31 July. http://mg.co.za/article/2013-07-31-south-africa-is-immature-says-swaziland-s pokersperson.

Mail \& Guardian (2013). "Zuma: Don’t Think Like an African - Pay Up for E-tolls." 22 October. https://mg.co.za/article/2013-10-22-zuma-dont-think-like-an-african-pay-up -for-e-tolls/.

Mail \& Guardian (2019). "What Netflix's Involvement in Nigeria's Massive Film Industry Really Means." 3 January. https://mg.co.za/article/2019-01-03-what-netflixs-involvem ent-in-nigerias-massive-film-industry-really-means/. 
Mandela, N. (1993). "South Africa's Future Foreign Policy." Foreign Affairs 72 (5): 86-97.

Mason, R. (2016). "Egypt's Future: Status Quo, Incremental Growth or Regional Leadership?" Middle East Policy XXIII (2): 76-94.

Masters, L. (2015). "South Africa's Emerging Parliamentary Diplomacy and Soft Power." Strategic Review of Southern Africa 37 (2): 74-93.

Masters, L. (2017). "South Africa's Post-Apartheid Foreign Policy Making and the Role of the President." Politeia 36 (1): 1-21.

Mbithi, P. (1972). "Harambee' Self-Help: The Kenyan Approach.” African Review 2 (1): 147-166.

McBain, W. (2019). "Canal+ and Netflix Eye Nollywood Opportunities." African Business 24 October. https://africanbusinessmagazine.com/region/canal-and-netflix-eye-nollyw ood-opportunities/.

Meighan, B. (2017). "Egypt's Foreign Reserves Have Begun to Recover, But Weak Foreign Direct Investment and Accumulating Debt Could Hinder Reforms Down the Line.” 5 December. https://carnegieendowment.org/sada/74920.

Melcangi, A. and Dentice, G. (2019). "Challenges for Egypt's Fragile Stability." https:// www.atlanticcouncil.org/blogs/menasource/challenges-for-egypt-s-fragile-stability/.

Miccoli, D. (2012). "Moses and Faruq. The Jews and the Study of History in Interwar Egypt 1920s-1940s." Quest: Issues in Contemporary Jewish History 4.

Miccoli, D. (2016). "A Fragile Cradle: Writing Jewishness, Nationhood, and Modernity in Cairo, 1920-1940.” Jewish Social Studies: History, Culture, Society 21 (3): 1-30.

Migai, A. (2011). "Abuse of Power and Corruption in Kenya: Will the New Constitution Enhance Government Accountability." Indiana Journal of Global Legal Studies 18 (1): 341-394.

Miller, J. (2012). "Global Nollywood: The Nigerian Movie Industry and Alternative Global Networks in Production and Distribution." Global Media and Communication 8 (2): $117-133$.

Mills, K. and Bloomfield, A. (2017). "African Resistance to the International Criminal Court: Halting the Advance of the Anti-impunity Norm." Review of International Studies 44 (1): 101-127.

Mimiko, N. O. (2017). "The Omoluabi Essence: An Interrogation of the History, Culture, and Identity of the Yoruba in Transitory Contexts." African and Asian Studies 16 (3): 243-258.

Ministry of Foreign Affairs and International Trade (2014). Kenya Foreign Policy. Nairobi: Ministry of Foreign Affairs and International Trade.

Ministry of Foreign Affairs and International Trade (2016). Strategic Plan 2013/14-2017/18. Nairobi: Ministry of Foreign Affairs and International Trade.

Miyandazi, L. (2012). Kenya's Military Intervention in Somalia: An Intricate Process. Policy \& Practice Brief Issue 19. Durban: The African Centre for the Constructive Resolution of Disputes.

Mohamed, H. (2019). "Egypt's Sisi Takes Over as New Head of African Union.” Aljazeer 10 February. https://www.aljazeera.com/news/2019/02/egypt-sisi-takes-head-africa n-union-190210140131428.html.

Monier, E. (2014). "The Arabness of Middle East regionalism: The Arab Spring and competition for discursive hegemony between Egypt, Iran and Turkey." Contemporary Politics 20 (4): 421-434.

Moore, C. (2014). "What Mbeki did next: Continuities in the presidential and postpresidential diplomacy of Thabo Mbeki." South African Fournal of International Affairs 21 (2): $161-175$. 
The Moscow Times (2019). "Russia's FSB Publishes Foreign Worker Statistics for First Time in 20 Years." 16 August. https://www.themoscowtimes.com/2019/08/16/russias-fsb-p ublishes-foreign-worker-statistics-for-first-time-in-20-years-a66895.

Mpungu, P. (2019). "Kenya's Corruption Crackdown: New Era, or Political Theatre?”27 July 2019. https://www.aljazeera.com/ajimpact/kenyas-corruption-crackdown-era-poli tical-theater-190726154554617.html.

MTN (2019). "Summary of MTN Nigeria Unaudited Results for the Six Months Ended 30 June 2019." 26 July. https://www.mtn.com/summary-of-mtn-nigeria-unaudite d-results-for-the-six-months-ended-30-june-2019/.

MTV Africa (2015). MAMA 2015 Awards. http://mama.mtv.com/news/2015-mtv-africa -music-awards-winners/.

Muhammad, A and Salawu, I. (2020). "Corruption and Nigeria's External Image in the Fourth Republic.” Journal of Management and Social Sciences 9 (1): 784-801.

Murage, J. (2007). "Harambee as an Indigenous Lived Philosophy: Empowering the Poor in the Kenyan Anglican Church." Submitted in partial fulfilment of Masters of Theology (Theology and Development), in the School of Theology and Religion, Faculty of Human Sciences and Management at the University of KwaZulu-Natal, Pietermaritzburg, South Africa.

Mutahi, P. and Ruteere, M. (2019). "Violence, Security and the Policing of Kenya's 2017 Elections." Fournal of Eastern African Studies 13 (2): 253-271.

Mwanika, P. (2013). Track-One Diplomacy and Post-Conflict Reconstruction: Kenya's Mediation of the Somali Conflict and Strategic Intervention Avenues. Submitted in fulfilment of the requirements for the degree of Doctor Philosophiae (D. Phil) in the Faculty of Business and Economic Sciences, Nelson Mandela Metropolitan University, Port Elizabeth, South Africa.

Mwanika, P. (2014). Kenya's Diplomacy on the Somali Conflict and Strategic Intervention: Soft-Power Diplomacy and Stabilization Dynamics. Scholar's Press.

Nafi, B. (2017). "Middle East Eye." 16 May. http://www.middleeasteye.net/columns/ egypt-no-longer-heart-arab-world-1843971737.

Nakhleh, E. (2013). "Propaganda and Power in the Middle East." Current History 122 (758): 356-363.

National Planning Commission (2011). National Development Plan 2030: Our Future - Make It Work. Pretoria: South Africa's National Planning Commission.

Ncube, G. (2019). "Gender and Naming Practices, and the Creation of a Taxonomy of Masculinities in the South African Soap Opera The Queen." Nomina Africana 33 (1): 1-8.

Ndlovu, S. (2010). "Sports as Cultural Diplomacy: The 2010 FIFA World Cup in South Africa's Foreign Policy." Soccer \& Society 11 (1/2): 144-153.

News24 (2013). "Egypt: Understanding the Political Instability." https://www.news24. com/news24/mynews24/Egypt-Understanding-the-political-instability-20130816.

News24 (2013). "Robert Mugabe cannot be blamed for name-calling." 13 December. www.news24.com/Archives/City-Press/Robert-Mugabe-cannot-be-blamed-for-name-c alling-20150429.

News24 (2017). "Xenophobia Fears: Fewer African Students Enrolling at SA Universities." 9 June. http://m.news24.com/news24/Africa/News/xenophobiafears-fe wer-african-students-enrolling-at-sa-universities-20170608.

Nginya, M. (2018). "International Election Observers in Kenya's 2017 Elections: Impartial or Partisan?" Fournal of African Elections 17 (1): 49-71.

Njiru, J. (2016). The Role of Cultural Diplomacy as a Tool for Advancing African Foreign Relations: A Case Study of Kenya. Master's Thesis. University of Nairobi College of Humanities and Social Sciences Institute of Diplomacy and International Studies. 
Nkoana-Mashabane, M. (2016). "Budget Vote Speech. Cape Town, 3 May.” Available at: www.dfa.gov.za/docs/speeches/2016/mash0503.htm.

Norbrook, N. (2020). "Nigeria's Musical Moment." The Africa Report, 6 January. https:// www.theafricareport.com/21775/nigerias-musical-moment/.

Nosseir, M. (2018). "Why Egypt's Soft Power has Dwindled Away." Arab Newes. July 24. http://www.arabnews.com/node/1156951.

Nussbaum, B. (2003). "African Culture and Ubuntu: Reflections of a South African in America." Perspectives 17 (1): 1-12.

Nwannennaya, C. and Abiodun T. (2017). "Illicit Drug Trafficking in Nigeria: Obstacle to National Development and Security." Fournal of Political Science and Public Affairs 5 (1): $1-6$.

Nye, J. (1990). Bound to Lead: The Changing Nature of American Power. New York: Basic Books.

Nye, J. (2004). Soft Power: The Means to Success in World Politics. New York: Public Affairs.

Nye, J. (2009). "Get Smart: Combining Hard and Soft Power." Foreign Affairs 88 (4): $160-163$.

Nye, J. (2011). The Future of Power. New York: Public Affairs.

Nye, J. (2012). "What's wrong with transformational leadership?." China Daily. 9 March. http://www.chinadaily.com.cn/opinion/project/2012-03/09/content_14799754.htm.

Obi, C. (2009). "Economic Community of West African States on the Ground: Comparing Peacekeeping in Liberia, Sierra Leone, Guinea Bissau, and Côte d'Ivoire." African Security 2 (2/3): 119-135.

Offiah, C. (2017). "Globalization and the Culture/Creative Industries: An Assessment of Nigeria's Position in The Global Space." IOSR Journal of Humanities and Social Science 22 (1): 11-23.

Ogbonna, C. and Ogunnubi, O. (2018). "Rethinking the Role of Nigeria's Technical Aid Corps as Soft Power: Rough Diamond or Fools' Gold." Ubuntu: Journal of Conflict and Social Transformation 7 (2): 121-141.

Ogunbadejo, O. (1980). "Nigeria’s Foreign Policy under Military Rule 1966-79." International Fournal 35 (4): 748-765.

Ogunnubi, O. (2020). "South Africa's Soft Power and the Diplomacy of Nuclear Geopolitics." Geofournal. doi:10.1007/s10708-020-10252-x.

Ogunnubi, O. and Amao, O. (2016). "South Africa's Emerging 'Soft Power' Influence in Africa and its Impending Limitations: Will the Giant Be Able to Weather the Storm?" African Security 9 (4): 299-319.

Ogunnubi, O. and Isike, C. (2015). "Regional Hegemonic Contention and the Asymmetry of Soft Power: A Comparative Analysis of South Africa and Nigeria." Strategic Review for Southern Africa 37 (1): 152-177.

Ogunnubi, O. and Isike, C. (2018). “Nigeria's Soft Power Sources: Between Potential and Illusion?" International Fournal of Politics, Culture and Society 31 (1): 49-67.

Ogunnubi, O. and Okeke-Uzodike, U. (2015). "South Africa's Foreign Policy and the Strategy of Soft Power." South African Fournal of International Affairs 22 (1): 23-41.

Ogunnubi, O. and Tella, O. (2017). "Framing South Africa's Soft Power through Non-State Sources." Strategic Analysis 41 (5): 478-495.

Ogunnubi, O., Onapajo, H. and Isike, C. (2017). "A Failing Regional Power? Nigeria's International Status in the Age of Boko Haram." Politikon 44 (3): 446-465.

Oh, E. (2014). "Nigeria's Film Industry: Nollywood Looks to Expand Globally." Executive Briefings on Trade, United States International Trade Commission.

Ojo, G. and Aghedo, I. (2013). "Image Re-branding in a Fragile State: The Case of Nigeria." The Korean Journal of Policy Studies 28 (2): 81-107. 
Ojo, O. (1980). "Nigeria and the Formation of ECOWAS." International Organization 34 (4): 571-604.

Ojo, O. (2019). "Cultural Renaissance and the Quest for Peace and Development in Nigeria." Fournal of International and Global Studies 10 (2): 86-102.

Okayafrica (2016). "The Full List of MTV Africa Music Awards 2016 Winners.” https:// www.okayafrica.com/mtv-africa-music-awards-2016-winners-mtvmama2016/.

Olanipekun, O. (2017). "Omoluabi: Re-thinking the Concept of Virtue in Yoruba Culture and Moral System.” Africology: The Fournal of Pan African Studies 10 (9): 217-231.

Olivier, G. (2003). "Is Thabo Mbeki Africa's Saviour?" International Affairs 79 (4): 815-828.

Olsen, G. (2018). "What Kenya Has to Show for Sending Troops into Somalia Seven Years Ago." The Conversation, 18 February. https://theconversation.com/what-kenya-ha s-to-show-for-sending-troops-into-somalia-seven-years-ago-90965.

Omo-Ogbebor, D. (2017). "Nigerian Foreign Policy Approach towards ECOWAS." International Fournal of Human Sciences 14 (4): 4015-4022.

Omotola, S. (2008). "From Importer to Exporter: The Changing Role of Nigeria in Promoting Democratic Values in Africa." In: Pretorius, J. (ed.), African Politics: Beyond the Third Wave of Democratisation. Cape Town: Juta and Company, pp. 33-51.

Onapajo, H. (2017). "Has Nigeria Defeated Boko Haram? An Appraisal of the CounterTerrorism Approach under the Buhari Administration." Strategic Analysis 41 (1): 61-73.

Onapajo, H. and Isike, C. (2016). "The Global Politics of Gay Rights: The Straining Relations between the West and Africa." The Fournal of Global Analysis 6 (1): 21-45.

Onifade, Temitayo Abayomi (n.d.). "Omoluabi: Perspectives to Value and Character in Traditional Yoruba Societies." https://www.Academia.Edu/17302435/Omoluabi_ Perspectives_To_VAlue_And_Character_In_Traditional_Yoruba_Societies.

Onishi, N. (2016). "Nigeria's Booming Film Industry Redefines African Life." The New York Times, 18 February. https://www.nytimes.com/2016/02/19/world/africa/with-a -boom-before-the-cameras-nigeria-redefines-african-life.html.

Open Society Foundations (2015). Effectiveness of Anti-Corruption Agencies in East Africa: Kenya, Tanzania and Uganda. New York: Open Society Foundations.

Oripeloye, H. and Omigbule, M. (2019). "The Yoruba of Nigeria and the Ontology of Death and Burial." In: Selin, H. and Rakoff, R. (eds), Death Across Cultures, Science Across Cultures: The History of Non-Western Science. Cham: Springer, pp. 193-205.

Orora, J. and Spiegel, H. (1980). "Harambee: Self-Help Development Projects in Kenya." International Journal of Comparative Sociology 21 (3/4): 243-253.

Oshewolo, S. (2019). "Rhetoric and Praxis: Nigeria's Africa Diplomacy and the Shaping of the African Union" The Round Table 108 (1): 49-65.

Oshewolo, S. (2019). "A Reconsideration of the Afrocentric Principle in Nigeria's Foreign Policy Framework." Geofournal, https://doi.org/10.1007/s10708-019-10114-1.

Osondu, M. (2015). "Membership in the Militalaterial Economic Organizations: An Evaluation of Nigeria's Participation in ECOWAS (1985-2014)." International Fournal of Development and Management Review 10 (1): 95-109.

Osuntokun, A. (2008). "Gulliver and the Lilliputians: Nigeria and Its Neighbours." In: Adebajo, A. and Mustapha, A. (eds), Gulliver's Troubles: Nigeria's Foreign Policy after the Cold War. KwaZulu-Natal: University of KwaZulu-Natal Press, pp. 141-159.

Owoyemi, M. Din, A. and Ahmad, Z. (2015). "The Diaspora Nigerians' Image Problem of Drug and Fraud: A Case Study of the Malaysian-Indonesian Experience through Newspaper Reports." Journal of Social Sciences 11 (2): 55-71.

Oxford Business Group (2018). "Tourism Rises in Kenya Once Again.” https://oxfordbusi nessgroup.com/overview/back-track-after-period-decline-tourism-sees-its-fortunes-rise. 
Pew Research Centre (2008). "Global Public Opinion in the Bush Years (2001-2008): America's Image; Muslims and Westerners; Global Economy; Rise of China." https://www.pewresea rch.org/global/2008/12/18/global-public-opinion-in-the-bush-years-2001-2008/.

Popescu, N. (2006). Russia's Soft Power Ambitions. CEPS Policy Briefs issue, 112. London: Centre for European Studies.

Portland (2019). Soft Power 30. London: Portland.

Premium Times (2015). "How Nigerian Govt. is Abandoning Its Citizens on Death Row Abroad." June 27. Accessed 10 November 2017. https://www.premiumtimesng.com/ features-and-interviews/185721-how-nigerian-govt-is-abandoning-its-citizens-on-death-r ow-abroad.html.

PricewaterhouseCoopers (2016). Impact of Corruption on Nigeria's Economy. PricewaterhouseCoopers.

PricewaterhouseCoopers (2017). The Business of Entertainment Harnessing growth opportunities in Entertainment, Media, Arts and Lifestyle. PricewaterhouseCoopers.

PricewaterhouseCoopers (2017). Spotlight: The Nigerian Film Industry. PricewaterhouseCoopers.

Prinsloo, B. (2019). "South Africa's Efforts to Project Influence and Power in Africa: 2000 to 2017." Strategic Review for Southern Africa 41 (1): 23-53.

Public Protector (2014). Secure in Comfort: Report on an Investigation into Allegations of Impropriety and Unethical Conduct Relating to the Installation and Implementation of Security Measures by the Department of Public Works at and in Respect of the Private Residence of President Facob Zuma at Nkandla in the KwaZulu-Natal Province. Report No. 25. Pretoria: Public Protector.

Purushothaman, U. (2010). "Shifting Perceptions of Power: Soft Power and India's Foreign Policy." Journal of Peace Studies 17 (2/3).

Qobo, M. and Nyathi, N. (2016). "Ubuntu, Public Policy Ethics and Tensions in South Africa's Foreign Policy." South African Fournal of International Affairs 23 (4): 421-436.

Ramo, J. (2004). The Beïing Consensus. London: The Foreign Policy Centre.

Recchia, S. (2020). "A Legitimate Sphere of Influence: Understanding France's Turn to Multilateralism in Africa." Fournal of Strategic Studies 43 (4): 508-533.

Reuters (2019). "Egypt on Edge after First anti-Sisi Protest for Years." 25 September. http s://www.reuters.com/article/us-egypt-protests/egypt-on-edge-after-first-anti-sisi-protest -for-years-idUSKBN1WA1Y3.

Riggs, C. (2013). "Colonial Visions: Egyptian Antiquities and Contested Histories in the Cairo Museum." Museum Worlds: Advances in Research 1 (1): 65-84.

The Rio Times (2017). "Brazil Reports Surge in 2017 Carnival Tourism Attendance." http s://riotimesonline.com/brazil-news/rio-business/brazil-registers-surge-in-2017-carnival -attendance/.

The Rio Times (2018). "Carnival 2018 to Inject $\mathrm{R} \$ 11.14$ Billion into Brazil’s Economy." 16 January. https://riotimesonline.com/brazil-news/rio-business/brazils-carnival-to-in ject-r1 1-14-billion-into-economy/.

Rivera, J. (2018). "An Inside View of African Diplomacy in the UN Security Council." 14 February. https://www.africaportal.org/features/inside-view-african-diplomacy-un-se curity-council/.

Rombo, D. and Lutomia, A. (2016). “This Is America': Narratives of Parenting Experiences by African Immigrant Parents from Cameroon, Kenya, and Somalia Living in the United States". Transnational Social Reviewe, 6 (1/2): 141-159.

Rubin, L. (2010). A Typology of Soft Powers in Middle East Politics. Dubai Initiative Working Paper No. 5. 
Saliu, H. and Omotola, S. (2008). "Can Nigeria Get a UN Security Council Seat?" South African Fournal of International Affairs 15 (1): 71-85.

Sanda, J. (2012). "Nigeria's Global Role in Peacekeeping: From the Congo through Lebanon to Bosnia Herzegovina." In: Jega, A. and Farris, J. (eds), Nigeria at Fifty: Contributions to Peace, Democracy, and Development. Abuja: Shehu Musa Yar'Adua Foundation, pp. 79-98.

Sayed, N. (2017). "Egypt Must Reclaim Soft Power Keys in the Region: Analysis." Egypt Today July 24. https://www.egypttoday.com/Article/2/13562/Egypt-must-reclaim -soft-power-keys-in-the-region-analysis.

Schoeman, M. (2015). "South Africa as an Emerging Power: From Label to 'Status Consistency?" South African Fournal of International Affairs 22 (4): 429-445.

Sehoole, C. (2015). "International Students Love South Africa, but Xenophobia Could Ce a Heartbreaker." The Conversation, 21 May. Available online at: https://theconversation. $\mathrm{com} /$ international-students-love-south-africa-but-xenophobia-could-be-a-heartbreaker41707.

Seymour, M. (2020). "The Problem with Soft Power." 14 November. Foreign Policy Research Institute. https://www.fpri.org/article/2020/09/the-problem-with-soft-power/.

Shambaugh, D. (2015). "China's Soft-Power Push: The Search for Respect." Foreign Affairs 94 (4): 99-107.

Sharma, K. (2020). "The Egyptian Actors Shattering Hollywood's Stereotypes of the Arab World." Vogue, 12 May. https://man.vogue.me/entertainment/egyptian-actors-holly wood/.

Sharp, J. (2020). Egypt: Background and U.S. Relations. Washington, DC: Congressional Research Service.

Sidiropoulos, E. (2014). "South Africa's Emerging Soft Power." Current History 113 (763): 197-202.

Singh, R. (2013). "Examining Xenophobic practices amongst University Students - A case study from Limpopo Province." Alternation Special Edition (7): 88-108.

Singleton, J. (2012). "Athletics, Kenya." In: Nauright, J. and Parrish, C. (eds), Sports Around the World: History, Culture, and Practice. Santa Barbara, CA: ABC-CLIO, LLC.

Smith, K. (2011). "South Africa and India as Regional Leaders: Gaining Acceptance and Legitimacy Through the Use of Soft Power." In: Modi, R. (ed.), South-South Cooperation: Africa on the Centre Stage. Basingstoke: Palgrave Macmillan.

Smith, K. (2012). "Soft Power: The Essence of South Africa's Foreign Policy." In: Landsberg, C. and van Wyk, J. (eds), South African Foreign Policy Review. Pretoria: Africa Institute of South Africa, pp. 68-83.

South African Government (2011). "White Paper on South African Foreign Policy Building a Better World: The Diplomacy of Ubuntu." https://www.gov.za/docum ents/white-paper-south-african-foreign-policy-building-better-world-diplomacy-ubuntu.

South African Government (2020). "Minister Tito Mboweni: Media Briefing on Economy and Coronavirus Covid-19." 14 April. https://www.gov.za/speeches/minister-tito-m boweni-media-briefing-economy-and-coronavirus-covid-19-14-apr-2020-0000.

South African National Planning Commission (2011). National Development Plan 2030: Our Future - Make It Work. Pretoria: South Africa's National Planning Commission.

Southern Africa -Towards Inclusive Economic Development (SA-TIED). (2020). "Impact of Covid-19 on the South African Economy: An Initial Analysis." Working Paper 111. http s://sa-tied.wider.unu.edu/article/impact-covid-19-south-african-economy-initial-analysis.

Spooner, S. (2014). "South Africa Universities Winning Race for Africa's Students: Here Are Their Secrets and Deals You Need to Know About." Mail \& Guardian, 15 
September. http://mgafrica.com/article/2014-09-11-why-south-africas-universities-offe r-africas-studentsthe-best-options-and-the-tricks-they-need-to-know.

Springborg, R. (2017). "Egypt's Economic Transition: Challenges and Prospects." International Development Policy 7.

Statistics South Africa (Stats SA). (2017). Poverty Trends in South Africa: An Examination of Absolute Poverty between 2006 and 2015. Pretoria: Statistics South Africa.

Sun, Y. (2014). Africa in China's Foreign Policy. John L. Thornton China Center and the Africa Growth Initiative at Brookings.

Sundberg, A. (2019). France - A Continuing Military Presence in Francophone Africa. Stockholm: Swedish Defence Research Institute.

Super Sport (2018). "Everyone Wants Piece of Salah.” 1 May. https://supersport.com/ football/news/180501_Everyone_wants_piece_of_Salah.

Tadros, S. (2017). "Does Egypt Still Matter?"15 March. https://www.hoover.org/resea rch/does-egypt-still-matter.

Tella, O. (2016). "A Declining or Stable Image? An Assessment of the United States' Soft Power in Africa." South African Fournal of International Affairs 23 (2): 151-166.

Tella, O. (2016). "Wielding Soft Power in Strategic Regions: An Analysis of China's Power of Attraction in Africa and the Middle East." Africa Review 8(2): 133-144.

Tella, O. (2016). "Understanding Xenophobia in South Africa: The Individual, the State and the International System." Insight on Africa 8 (2): 142-158.

Tella, O. (2017). "South Africa in BRICS: The Regional Power's Soft Power and Soft Balancing." Politikon 44 (3): 387-403.

Tella, O. (2017). "Attractions and Limitations of Nigeria's Soft Power." Journal of Global Analysis 7 (2): 109-128.

Tella, O. (2018). "Currencies, Constraints and Contradictions of South Africa's Soft Power." Fournal of Asian and African Studies 53 (3): 420-436.

Tella, O. (2018). “Is Nigeria a Soft Power State?” Social Dynamics 44 (2): 376-394.

Tella, O. (2018). "Boko Haram Terrorism and Counter-Terrorism: The Soft Power Context." Journal of Asian and African Studies 53 (6): 815-829.

Tella, O. (2018). "Agenda 2063 and Its Implications for Africa's Soft Power." Fournal of Black Studies 49 (7): 714-730.

Tella, O. (2018). "South African Higher Education: The Paradox of Soft Power and Xenophobia". In: Akinola, A. (ed.) The Political Economy of Xenophobia in Africa. Cham: Springer.

Tella, O. (2018). Nigeria-South Africa Relations: A Roller Coaster Ride. Daily Maverick 19 June. https://www.dailymaverick.co.za/opinionista/2018-06-19-nigeria-south-africa -relations-a-roller-coaster-ride/.

Tella, O. (2018). "Boko Haram Terrorism and Counter-Terrorism: The Soft Power Context." Fournal of Asian and African Studies 53 (6): 815-829.

Tella, O. (2019). Revisiting the Georgetown Agreement: Comparative Region-building in Africa, the Caribbean, and the Pacific. Policy Brief 4. Johannesburg: Institute for Pan-African Thought and Conversation.

Tella, O. (2019). "Internal, Regional and External Impediments to Nigeria and South Africa's Hegemonic Competence in Africa." In: Tella, O. (ed.). Nigeria-South Africa Relations and Regional Hegemonic Competence. Cham: Springer.

Tella, O. (2019). South Africa and the Great Powers on the United Nations Security Council. Johannesburg: Institute for Pan-African Thought and Conversation, University of Johannesburg.

Tella, O. (2020). "Soft Power Individuals in Nigeria and South Africa: An Appraisal of Olusegun Obasanjo's and Thabo Mbeki's Power of Attraction." Round Table 109 (5): 574-585. 
Tella, O. and Ogunnubi, O. (2014). "Hegemony or Survival: South Africa's Soft Power and the Challenge of Xenophobia." Africa Insight 44 (3): 145-163.

The Equal Rights Trust (2012). In the Spirit of Harambee: Addressing Discrimination and Inequality in Kenya. ERT Country Report Series: London. https://www.equalrightstrust.org/sp irit-harambee-addressing-discrimination-and-inequality-kenya.

This Day (2017). "4,281 Nigerians Deported from Europe, US, African Countries Mid 2017." October 9. https://www.thisdaylive.com/index.php/2017/10/09/4281-nigeria ns-deported-from-europe-us-african-countries-mid-2017/.

Thussu, D. (2014). De-Americanizing Soft Power Discourse?Los Angeles: Figueroa Press.

Tieku, T. (2004). "Explaining the Clash and Accommodation of Interests of Major Actors in the Creation of the African Union." African Affairs 103 (411): 249-267.

Time (2019). "Time 100: Mohammed Salah." https://time.com/collection/100-most-in fluential-people-2019/5567841/mohamed-salah/.

Time Magazine (2019). "Time 100 Most Influential People 2019.” https://time.com/col lection/100-most-influential-people-2019/.

Times Higher Education (2020). "Best Universities in Africa 2020." https://www.timeshigh ereducation.com/student/best-universities/best-universities-africa.

Tourangbam, M. (2020). "India's Rise and Why Soft Power Matters." https://diplomatist. com/2020/08/25/indias-rise-and-why-soft-power-matters/.

Transparency International (2016-2021). "Corruption Perceptions Index.” https://www. transparency.org/en/cpi.

Trinkunas, H. (2014). Brazil's Rise: Seeking Influence on Global Governance. Brookings: Latin America Initiative Foreign Policy.

Tsourapas, G. (2018a). "Authoritarian Emigration States: Soft Power and Cross-border Mobility in the Middle East." International Political Science Review 39 (3): 400-416.

Tsourapas, G. (2018b). "Egypt: Migration and Diaspora Politics in an Emerging Transit Country." https://www.migrationpolicy.org/article/egypt-migration-and-diaspora-poli tics-emerging-transit-country.

Tsygankov, A. (2006). "If not by Tanks, Then by Banks? The Role of Soft Power in Putin's Foreign Policy.” Europe-Asia Studies 58 (7): 1079-1099.

Tucker, R., Onywera, V., and Santos-Concejero, J. (2015). "Analysis of the Kenyan DistanceRunning Phenomenon." International Fournal of Sports Physiology and Performance 10: 285-291.

Turpin, A. (2019). "The Grand Inga Dam Project Poses Fiscal Risks Similar to the Controversial Arms Deal." Daily Maverick, 13 December. https://www.dailymaverick.co. za/article/2019-12-13-the-grand-inga-dam-project-poses-fiscal-risks-similar-to-the-contr oversial-arms-deal/.

Ujara, E. and Ibietan, J. (2014). "Citizen Diplomacy and Nigeria's International Image: The Social Constructivist Explanation." Covenant Fournal of Business and Social Sciences 6 (2): $40-57$.

Umezurike, S. Iwu, C. Asuelime, L., and Umezurike, C. (2017). "Re-examining Nigeria's Contributions to the African Union and the Domestic Socio-Economic Ramifications." Fournal of Economics and Behavioral Studies 9 (1): 17-26.

UNHCR (2020). "UNHCR Outraged by Attack on Camp Hosting Displaced People in Cameroon, at Least 18 People Killed." 4 August. https://www.unhcr.org/news/brief ing/2020/8/5f291a704/unhcr-outraged-attack-camp-hosting-displaced-people-cameroo n-18-people.html.

United Nations (2015). Universal Declaration of Human Rights. New York: United Nations.

United Nations Office on Drugs and Crime (2005). Transnational Organized Crime in the West African Region. New York: The United Nations. 
United Nations Office on Drugs and Crime (2019). Corruption in Nigeria: Patterns and Trends: Second Survey on Corruption as Experienced by the Population. New York: United Nations.

van der Westhuizen, J. (2008). "Popular Culture, Discourse and Divergent Identities:

Reconstructing South Africa as an African State." African Identities 6 (1): 45-61.

van der Westhuizen, J. (2016). "South Africa's Soft Power Conundrum: How to Win

Friends and Influence People in Africa." Fournal of Political Power 9 (3): 449-465.

van Wyk, J. (2014). "Playing in the Orchestra of Peace: South Africa's Relations with Iraq (1998-2003)." South African Fournal of International Affairs 21 (2): 193-211.

VOA (2020). "69 People Killed in Nigerian Village by Suspected Boko Haram Militants."

10 June. https://www.voanews.com/africa/69-people-killed-nigerian-village-suspectedboko-haram-militants.

Wagner, C. (2012). Emerging Powers in Regional Architecture. Asia Division German Institute for International and Security Affairs Working Paper FG 7. Berlin: German Institute for International and Security Affairs.

Wamanji, E. (2016). "Kenya Can Use Sports as Strategic Diplomatic Tool." People Daily. May 11. https://mediamaxnetwork.co.ke/people-daily/kenya-can-use-sports-as-stra tegic-diplomatic-tool-219379/amp/.

Whiting, K. (2019). "How Mo Salah May Have Reduced Islamophobia in Liverpool." 12 June. https://www.weforum.org/agenda/2019/06/how-mo-salah-might-have-reducedislamophobia-in-liverpool/.

Wood, M. (1998). "The Use of the Pharaonic Past in Modern Egyptian Nationalism." Fournal of the American Research Center in Egypt 35: 179-196.

World Athletics (2019). "Medal Table." https://www.worldathletics.org/Competitions/ world-athletics-championships/iaaf-world-athletics-championships-doha-2019-7 125365/ medaltable.

World Bank (2018). South Africa Economic Update: Fobs and Inequality. Washington, DC: World Bank.

World Bank (2019). World Development Indicators. Washington DC: World Bank.

World Bank (2019). Migration and Remittances: Recent Developments and Outlook. New York: World Bank.

World Bank (2019). "World Bank Group to Extend Current Strategy in Egypt to Maintain Momentum on Reforms." 30 April. https://www.worldbank.org/en/news/press-releas e/2019/04/30/world-bank-group-to-extend-current-strategy-in-egypt-to-maintain-mom entum-on-reforms.

World Bank (2020). "The World Bank in Egypt." https://www.worldbank.org/en/coun try/egypt/overview.

World Economic Forum (2019). "These Countries Have the Most Women in Parliament." https://www.weforum.org/agenda/2019/02/chart-of-the-day-these-countries-have-the -most-women-in-parliament/.

World Travel and Tourism Council (2018). The Economic Impact of Travel and Tourism: Kenya. London: WTTC.

World Travel and Tourism Council (2020). Travel and Tourism: Global Economic Impact and Trend 2020. London: WTTC.

Xinbo, W. (2010). "Understanding the Geopolitical Implications of the Global Financial Crisis." The Washington Quarterly 33 (4): 155-163.

Yadav, N. (2020). "These Are the 10 Most-affected Countries with the Highest Number of COVID-19 Cases." Business Insider, 27 October. https://www.businessinsider.in/poli tics/india/news/check-out-the-10-most-affected-countries-with-the-highest-number-of-c oronavirus-cases/slidelist/76275918.cms. 
Youssef, D. (2017). "Egypt's Soft Power in the Arab World." Washington Examiner, 12 April. https://www.washingtonexaminer.com/egypts-soft-power-in-the-arab-world.

Zhao, S. (2010). "The China Model: Can it replace the Western Model of Modernization?" Fournal of Contemporary China 19 (65): 419-436.

Zohry, A. (2014). "Migration and Development in Egypt." In: Bommes, M., Fassmann, H., and Sievers, W. (eds), Migration from the Middle East and North Africa to Europe: Past Developments, Current Status and Future Potentials. Amsterdam: Amsterdam University Press.

Zohry, A. (2013). "Egypt's International Migration after the Revolution: Is There Any Change?" Confluences Méditerranéen 87: 47-54.

Zondi, S. (2015). "Africanity, Pan-Africanism and African renaissance: South Africa's Africa agenda under Mbeki and Zuma." In Masters, L., Zondi, S., and van Wyk, J. (eds), South African Foreign Policy Review (Vol. 2, pp. 97-118). Pretoria: Africa Institute of South Africa. 


\section{Index}

102 Paradise Complex (TV show) 84

Abacha, Sani 50, 111

Abbas, Raymond ('Hushpuppi') 67

Abdel-Wahed, M. 143

Aboul-Ela, H. 125

Achebe, Chinua 45, 50

Adamson, F. and Tsourapas, G. 130

Adebajo, A. 43, 45

Adebanwi, W. 57

Adebanwi, W. and Obadare, E. 64

Adeboye, Enoch 50

Adedibu, Lamidi 65

Adesanya, Israel 50

Adesina, Akinwumi 63

Adesina, O. 7

Adichie, Chimamanda 45, 50

Adjaye, David 50

Adu, Sade 48

AfCFTA (African Continental Free Trade Area): Egypt and 137; South Africa and 115

AFCON (Africa Cup of Nations) 86-7

Afolayan, Kunle 43

Africa: Abuja, exercise of soft power by 176; admired brands from 102-3; Africa as model, notion of 174-8; Africa Policy Institute, Kenya and 154; 'Africa Rising' 174; African Development Bank (ADB), TAC in Nigeria and 59; African Renaissance, pursuit of 90-91; agency in African solutions to African challenges 174; CAF (Confederation of African Football) 86, 131; cultural exports, popularity of 175; Egypt, cradle of civilization 174; Egypt, Pharaonism in $1,8,9,123-5,176,177$; freedom in 66 ; humanism of, lessons from 31 ; Janus-faced nature of relationship with
South Africa 115-17; Kenya, athletics success in 174; Kenya, obstacles to soft power in 178; Kenya, self-help systems in 177-8; Nigeria, Nollywood in 4, 6, 7, 8, 41, 42-6, 174; philosophies of 1, 176; Rwanda, gender equality in 174;

Rwanda, growth rate in 174; soft power, capacity for 1, 174, 175; soft power, definition of 1 ; soft power, relevance in international politics 1-3; soft power, scholarship on 4-7; soft power, sources of 175-6; South Africa, FIFA World Cup (2010) in 8, 174; South Africa, peacemaking by 177; South Africa, quintessential soft power state 176-7

African Union (AU) 5, 8, 177; inaugural summit (2002) in South Africa 97;

Nigeria and 50-51, 60-62; Peace and Security Council (PSG) 61, 114; TAC in Nigeria and 59

AFRICOM (US African Command) 72-3

Afrobeats of Nigeria 4, 8, 41, 46-9

Afrophobia 178

AGA (African Governance Architecture) 62

Agbaje, A. and Adejumobi, S. 66-7

AGOA (African Growth and Opportunity Act, US 2000) 150

AKA 83, 84, 175

Akindele, Funke 45

Akinnuoye-Agbaje, Adewale 48

Akinola, A. 59

Akinola, A. and Ogunnubi, O. 7

Akinola, A. and Okeke-Uzodike, U. 29, 31

Akinyemi, Bolaji 57

Akokpari, J. 97, 98

Akon 175

Akunyili, Dora 69

Al Ahram 143 
Al Fazeera 16, 134, 143, 175

Alao-Akala, Christopher 65

Alden, C. and Le Pere, G. 98, 103

Alden, G. and Schoeman, M. 82

Alexander of Macedonia 35

Algeria 3, 51, 61, 66, 110, 134, 149, 178; African Renaissance, pursuit of 90-91; economic power of 4; Global Soft Power Index for 3

Ali, Hussein 162

Ali-Moufouri, Françoise-Agnès 70

Alicia Keys 175

Alison, L. and Monnington, T. 152

Alrababa'h, A., Marble, W., Mousa, S., and Siegel, A. 131-2

Aly, E. 134

Amadi, Elechi 45

Amao, O. and Maiangwa, B. 70

American Chamber of Commerce in Egypt 130

AMIB (AU Mission to Burundi) 95, 98

Amin, Idi 157

AMSOM (African Union Mission in Somalia) 161-2

ANC (African National Congress): Nigeria and 58; South Africa and 29, 93, 108, 110,111

Anglo-Leasing Procurement scandal (2005) in Kenya 169

Angola 27, 149, 160, 178; economic power of 4; Nigeria and 53, 57, 58, 61, 62, 65, 66, 71, 73; South Africa and 86, 94, 95, 97, 104, 110, 117

Annan, Kofi 152, 165

Anozie, Nonso 48

Anti-Corruption Commission in Kenya, establishment of 169

ANWFZ (African Nuclear Weapons Free Zone Treaty) 100

April, Y. 6

APRM (African Peer Review Mechanism) 177; Nigeria and 59, 62; South Africa and $90,98-9$

APSA (African Peace and Security Architecture): Egypt and 136; Nigeria and 62; South Africa and 95

Arab Spring 177

Argumenty i Fakty 23

Arusha Peace and Reconstruction Agreement (2000) 95

Asher, Zain 50

ASI (African Solidarity Initiative) participation of Egypt in 136-7

Associated Press 17 athletes of Kenya, influence of 150-52

AUAMIL (UN Mission in Liberia) 135

Aubameyang, Pierre-Emerick 130

Australia, soft power score for 2

Austria, soft power score for 2

Ayoade, Richard 48

Azir, Hany 130

Aziz, Mahmoud Abdel 134

Bach, D. 53, 68

Bahgat, G. 125. 126

Bakare, Ade 49

Bakare, O. and Read, R. 63

Ballerini, F. 28

Balogun, Tafa 64

Bamidele, O. 62

Ban Ki-moon 161

Banda, Hastings 160

Bandele, Biyi 43

El-Banhawy, Y. 134, 140

Barkindo, Mohammad 63

Barnard, I. 84

Barrow, Adama 51-2

Al Bashir, Omar 109, 116, 117

Bayoumi, Mohammed 133

BBC (British Broadcasting Corporation)

175; BBC News in Nigeria 45, 65, 67, 69

Bédié, Henri Konan 51

De Bel-Air, F. 130

Belgium, soft power score for 2

Bertonha, J. 26, 27

BET (Black Entertainment TV) in South Africa 83

Beyoncé 47, 48, 175

Bhagawati, J. 74

Big Brother Africa (TV show) 49

Big Brother Naija (TV show) 7, 49

Biko, Steve 90, 177

Bird, Ben 132

Black Coffee 83

Black Consciousness 177

Blarel, N. 24

Blaydes, L. 139, 140

Bloomberg 17, 49

Boateng, Oswald 49

Bodomo, A. 6

Boko Haram terrorism 6, 7, 176; Nigeria and 41, 69-72

Bound to Lead (Nye, J.) 8, 12

Bouteflika, Abdelaziz 61

Boyega, John 48

Brand Africa 49, 102-3

Brand Finance 1, 3 


\section{Index}

Brand South Africa 86

Brazil: BRICS associations 28; Carnival in 27; pacific and conciliatory posture 27, 175; popular culture, appeal of 26-7; regional security environment 27-8; soft power score for (Soft Power 30) 2

Brenthurst Foundation 104, 106

BRICS countries 5, 6, 8, 25, 28, 30, 175, 177; South Africa 30, 82, 94, 97, 99, 104, 105, 111, 116

Buhari, Muhammadu (and administration of) 52, 63, 71

Burgess, S. 50, 52, 54, 59

Burna Boy 46, 47

Burundi 62, 66, 177, 178; conflict zone 177; Kenya and 156, 158, 159, 164; South Africa and 91, 94, 95, 98, 99, $110,111,117$

Bush, George W. 14

Busiswa 83

Busolo, M. 152

Byron, K. and Chepyator-Thomson, J. 152

CAF (Confederation of African Football) 86, 131

Calland, R. and Recht, S. 107

Cameron, David 65

Cameroon 3, 43, 45, 66, 69, 70, 71, 74-5; crisis over Bakassi Peninsula with Nigeria 53

Campbell, John 43-5, 68, 71, 73

Canada, soft power score for 2

Carr, H.E. 15

Caster Semenya 84

Castro, Fidel 110

Central African Republic (CAR) 54, 75, 94, 98, 161, 164; conflict zone 177

CGTN (China Global Television Network) in Kenya 9

Chaka Chaka, Yvonne 83

Chamillionaire 48

charismatic leaders, influence of 89-92

Chatterjee, S. 153

Cheeseman, N., Kanyinga, K., Lynch, G., Ruteere, M., and Willis, J. 166

Chege, M. 166, 168

Chepkwony, K. 33

Chetty, D. 32

Chicken Gate scandal (2014) in Kenya 169

Chieni, S. 34

Chikezie, Caroline 48

Childish Gambino 83

China: ASEAN Regional Forum (ARF) and 20-21; Asia-Pacific Dream 17; BJC
(Beijing Consensus) 18-19, 21; BRI (Belt and Road Initiative) 17; CGTN (China Global Television Network) 16, 17, 175; China-Association of Southeast Asian Nations (ASEAN) free trade area 20-21; 'China Model' 18-19; China Power 18; Chinese Dream 17; foreign policy of, soft power and 20; great power influence on Nigeria 73-4; HSK (Hanyu Shuiping Kaoshi) 18; multilateral institutions and 20-21; negative perceptions of, counteractions against 20; powers of attraction 175; SCO (Shanghai Cooperation Organisation) 21; Silk Road Economic Belt 17; soft power resources of 8; soft power score for (Soft Power 30) 2; Southeast Asia Treaty of Amity and Cooperation and 20-21; 21 st Century Maritime Silk Road 17; UN peacekeeping participation 21;

Xinhua News Agency 17

Chiroro, B. 4, 92, 100, 105

Cho, S., Connors, E., Fatima, F., and Yalim, U. 167-8

Cho, Y. and Jeong, J. 17-18, 20

Chomsky, N. and Achcar, G. 140

Chris Brown 47, 83, 175

CIS (Commonwealth of Independent States) 19, 21, 22

civil society organisations, influence of 101-3

Glinton, Bill (and administration of) 55

Cloete, N., Sheppard, C., and Bailey, T. 89

CMC di Ravenna corruption scandal (2019) in Kenya 169

CNBC Africa 73, 107-8

CNN (Cable News Network) 16, 50, 143, 175

Coaston, J. and O'Donnell, B. 48

Coetzee, John Maxwell 175

Cold-Ravnkilde, S. 92

Colla, E. 35, 36, 124-5

COMESA (Common Market for East and Southern Africa) 158, 160, 161

conflict resolution by Nigeria, significance of 32

Confucianism 17-18

Confucius Institutes 18

Congo Democratic Republic (DRC) 3, 21, 178; conflict zone 177, 178; Kenya and 156, 157-8, 159, 160, 161, 164; Nigeria and $43,54,65$; peace mission by Nigeria in 52-3; South Africa and 87, 
91, 94-5, 97-9, 101, 103, 110-12, 114, 115

Copyright Commission in Nigeria 43

Cormack, Allan 89

corporate influencers in Nigeria 49

Corruption Perception Index: Kenya on 170; Nigeria on 65

COSATU (Congress of South African Trade Unions) 101, 108

Council on Foreign Relations 18, 140

COVID-19 pandemic 83, 106, 108, 132, 154,174

CRAI (Citizenship Rights in Africa Initiative) 112; South Africa and 112

Cricket World Cup (2003) in South Africa 85

Da Cruz, J. and Stephens, L. 68

CSSDCA (Conference on Security, Stability, Development and Co-operation in Africa) 61

culture: cultural exports from Africa, popularity of 175; entertainment and culture from Egypt, influence of 132-5; Kenya, cultural symbolism of Harambee in 34-5; Lamu Cultural Festival 152; Mombasa International Cultural Festival 152; popular culture of Brazil, appeal of 26-7; Rusinga Cultural Festival in Kenya 178; soft power, culture as source of 14-15

Ćwiek-Karpowicz, J. 22, 23

Cybernetics Lab top African universities: South Africa 87-8

Czech Republic, soft power score for 2

Daily Telegraph 23

Dalai Lama 5, 101, 110

Dangote Group in Nigeria, influence of 49

Dauda, B. 29, 31, 32, 55-6

Davido 46, 47, 48, 175

Dawood, I. 130

D'Banj 46, 47

De Lima, M. and Hirst, M. 26

Déby, Idriss 53-4

democracy deficit in Nigeria 63-7

democracy promotion: by Nigeria $50-52$; shortfall of South Africa on 109-12; by South Africa 94-6

Denmark, soft power score for 2

Diamond 175

diaspora: of Egypt, influence of (and remittances from) 129-30; of Nigeria, influence of 50

Diko, Khusela 108
Ding, S. 16-17

Diop, C. 35,36

diplomacy of Ubuntu, White Paper on 30-31

diplomatic engagements by Egypt 135-8

DIRCO (Department of International

Relations and Cooperation) in South

Africa 93-4, 101, 104, 112

District 9 (film) 68

DJ Maphorisa 83, 84, 175

Dlamini-Zuma, Nkosazana 5

Al-Dosary, S. 132

Dowse, S. 6, 86

Drake 46, 47, 175

Dram ani Mahama, John 52

Du Bois, W.E.B. 160

Dubai International Film Festival (DIFF) 134

Dube, Lucky 83

DW News Africa 108, 137

EAC (East African Community) 154, 158, 161, 166, 169, 178

EACG (Ethics and Anti-Corruption

Commission) in Kenya 169

Ebegbulem, J. 53

Ebeid, Nabila 134

ECOMOG (Economic Community of West African States Monitoring Group) $51,59,61$

economics: challenges for Egypt 141-2; constraints on South Africa 104-6; diplomacy by Kenya 157-9; Economics and Peace, Institute for 70, 105; power of Egypt, Kenya, Nigeria and South Africa 4

The Economist 142, 174

ECOWAS (Economic Community of West African States) 8, 110, 111; Nigeria and 51-2, 53, 57-8, 59-60, 74, 75

Edo, Ini 45

Edochie, Pete 45

EFCG (Economic and Financial Crimes Commission) in Nigeria 64

Egwemi, V. 69

Egypt 3, 9; AfCFTA (African Continental Free Trade Area) 137; APSA (African Peace and Security Architecture) and 136; ASI (African Solidarity Initiative) participation 136-7; contemporary PanArabism and 127-8; cradle of civilization 174; diaspora of (and remittances from) 129-30; diplomatic engagements 135-8; economic challenges 141-2; economic power of 4; Egyptian 
Antiquities Museum 35-6; film industry, influence of 133-4; foreign interventions and economic decline 36; GCC (Gulf Cooperation Council) and 138; geopolitical influence, decline in 142-4; Global Soft Power Index for 3; human rights abuses in 139-40; international organisations, membership of 135-8; Islam, promotion abroad of 177; IsraeliPalestinian conflict and 9, 177; literary icons, influence of 134-5; MINURSO (UN Mission for Referendum in Western Sahara) and 135; MINUSMA (UN Multidimensional Integrated Stabilization Mission in Mali) 135; MINUSTAH (UN Stabilization Mission in Haiti) and 135; MONUSCO (UN Organization Stabilization Mission in Democratic Republic of Congo) 135; Museum of Islamic Art 35-6; Muslim Brotherhood in 123, 138, 139, 140; nationalism and Pharaonism in 36; OIC (Organisation of Islamic Conference) 136; Pan-Arabism in 9, 177; Pan-Arabism of Nasser and 125-7; PCRD (Post-Conflict Reconstruction and Development) and 136; pharaonic past, reinforcement of 36 ; Pharaonism in 1, 8, 9, 123-5, 176, 177; political instability in 139-40; professionals from, impact of 129; skilled workers, emigration of 128-30; soft power in, scholarship on 7; soft power in Yemen of, salience of 127; soft power of, decline of 138-44; soft power of, rise of 123-38; sport diplomacy, Mo Salah effect and 130-32; UNAMI (UN Assistance Mission for Iraq) 135; UNAMID (AU-UN Hybrid Operation in Darfur) and 135; United Nations (UN) peacekeeping missions, contributions to 135-6; United Nations (UN) regional office locations in 136; UNMIL (UN Mission in Liberia) 135; UNMISS (UN Mission in South Sudan) 135; UNOCI (UN Operation in Côte d'Ivoire) and 135; values of Pharaonism for 35-6

Egypt Today 130

EIU (Economist Intelligence Unit) 66 Ejiofor, Chiwetel 48

ElBaradei, Mohamed 140

Elder, C., Stigant, S., and Claes, J. 164, 165 electoral violence on Kenya 164-7

Queen Elizabeth II 65, 159

ElSebaie, R. and Mouawad, A. 123
Emmanuel, K. 155, 157, 158, 159, 160

Emtee 84

environmental politics, role of South Africa in $100-101$

Equal Rights Trust 33

Erivo, Cynthia 48

Ernst \& Young 47

ERS (Economic Recovery Strategy for Wealth and Employment Creation) in Kenya 158-9

Ethiopia 3, 4, 57, 61, 66, 94, 95, 102, 103, 144, 178; economic power of 4; Kenya and 149, 151, 155, 157, 159, 160, 161

Ettang, D. and Leeke, N. 68

Evoy, C. 155, 158, 159, 161

Eyadéma, Faure 52

Eyadéma, Gnassingbé 52

Ezenagu, N. and Enohuean, E. 71

Facebook 16

Faisal, King of Saudi Arabia 127

Fanack 133, 134, 140, 142

Fani-Kayode, Femi 52

fashion industry, influence of: Kenya and 149-50; Nigeria and 49

Fassie, Brenda 83

Fawole, A. 58, 74

FDI (Foreign Direct Investment) 63, 129, 138, 142, 166, 170

February, J. 108

Ferguson, Niall 13, 15

FIFA World Cup (2010) in South Africa 85-6, 90

Fifty (film by Biyi Bandele) 43

Le Figaro 23

film industry in Egypt, influence of 133-4; see also Nollywood in Nigeria

Finland, soft power score for 2

First Bank, influence in Nigeria of 49

Fjelde, H. and Höglund, K. 166

Flavour 46

Folarin-Coker, Folake 49

Folawiyo, Lisa 49

Forbes 49, 67

Foreign Affairs 96

France: great power influence on Nigeria 74-5; soft power score for 2

France 24 48, 70, 137, 175

Pope Francis 160

Frazer, G. 73

Freedom House 65-6

freedom in Africa, Nigeria and 66

Freeman, K. 85

Fund for Peace 71 
G20 8, 82, 97, 99, 177

Gallup 15, 113

The Gambia 117, 164; democracy promotion in 41, 176; Nigeria and 51, 52, 53, $58,62,66$

Gandhi, Mohandas K. 'Mahatma' 24-5, 90

Gbagbo, Laurent 51, 75, 110, 111

GCC (Gulf Cooperation Council) 138

Geldenhuys, D. 4

Generations (TV show) 83, 84

geo-political influence of Egypt, decline in $142-4$

George, Bode 64

Germany, soft power score for 2

Ghaddafi, Muammar 61, 73, 116, 160

Ghafar, A. 140, 141

Gill, B. and Huang, Y. 18, 19, 20

Giorgis, H. 47

Globacom Group, influence of 49

Global Fire Power 123, 149, 155

Global Fire Power Index (Global Fire Power) 4

global governance, UN and efforts at 62-3

Global Peace Index 105

Global Soft Power Index (Brand Finance) 1, 2-3

Global Tourism Forum 153

Godfrey, M. and Mutiso, G. 33

Goldenberg scandal (1990-93) in Kenya 169

Goldstone, Richard 91

Gomora (TV show) 84

Al-Gondi, Nadia 134

Google 16

Grafton, R., Wyrwoll, P., White, C., and Allendes, D. 144

Graham, S. 4

Gramsci, A. 14

Grand Regency Hotel scandal (2008) in Kenya 169

Greece, soft power score for 2

Grix, J. and Lee, D. 6, 85, 86

Guci, General Robert 51

Gupta family (Guptagate and) 108

Guterres, António 135

Habib, A. 109

Haftar, Khalifa 137

Hairsine, K. 115

El Hakim, Tawfik 134

Hamed, Y. 141

Hamman, S. and Omojuwa, K. 53

Hamzawy, A. 137, 144

Hanauer, L. and Morris, I. 73
Hansen, S. 157

Harambee in Kenya 1, 3, 8, 9, 149, 154-5, $156,176,177-8$

Hardy, S. 102

Hariri, Rafiq 109

Harrington, J. and Manji, A. 169

Hartmann, C. 51-2

Heil, Dominic 107-8

Hell's Gate National Park in Kenya 152

Hengari, A. 109

Heungoup, H. 70

higher education in South Africa, influence of $87-9$

Hill, F. 21, 22

Hinnebusch, R. 125-6, 127

HIV/AIDS infections in South Africa 86

Hove, M. and Ndawana, E. 139, 141

Howell, J. 153, 155, 158

$\mathrm{Hu}$ Jintao 17

Huang, Y. and Ding, S. 18, 20

Hulse, M. 60

human rights: abuses in Egypt 139-40; double standards in South Africa on 109-12

Human Rights Commission in Kenya 169

Human Rights Council (Resolution 17/19) 116

Human Rights Watch 71, 134, 163; World Report (Johannesburg, 2014) 114

Hungary, soft power score for 2

Hussein, Taha 134

IAAF (International Association of Athletics Federations) 151

Ibori, James 64

IBSA (India-Brazil-South Africa Dialogue Forum) 82, 177

Ibu, Mr 45

ICC (International Criminal Court) 163-4; Kenya and 9, 149, 162-4, 178; stance of South Africa on 116-17

ICG (International Crisis Group) 70, 157

ICPC (Independent Corrupt Practices and Other Related Offences Commission) 63

Idowu, A. and Ogunnubi, O. 7

IEBC (Independent Electoral and Boundaries Commission) in Kenya 165

IGAD (Intergovernmental Authority on Development), Kenyan membership of 154, 161

Iheme, Osita 45

Ikedieze, Chinedu 45

INCB (International Narcotics Control Board) 68 


\section{Index}

India: BRICS associations 25; democratic politics, value of 25; diaspora of, power of 24; foreign policy approach 24-5; GATT (General Agreement on Tariffs and Trade) and 25; growth potential of 26; ICCR (Indian Council for Cultural Relations) 24; NDTV (New Delhi Television) 16,175 ; soft power of 175 ;

UNCTAD (UN Conference on Trade and Development) and 25

indigenous communities and Harambee in Kenya 33-4

industrial investments by South African companies 103

inequalities in South Africa 104-5

The Informant (film) 68

International Camel Derby Festival in Kenya 152

International Development Department (Kenya) 164-5

international organisations, Egyptian membership of 135-8

International Trade Centre in Kenya 150

IOL (Independent Online, South Africa) 101

IOM (International Organisation for Migration) 130

IPU (Inter-Parliamentary Union) 106

Ireland, soft power score for 2

Isidingo (TV show) 84

Islam, Egyptian promotion abroad of 177

Israeli-Palestinian conflict, Egypt and 9, 177

Italy, soft power score for 2

Ives, S. 84

Iyke, Jim 45

Jacobs, Olu 45

Jaishankar, D. 25-6

Jammeh, Yahya 51-2

Japan, soft power score for 2

Jewell, C. 42

Jidenna 48, 175

Jinadu, A. 56-7, 58

JME (Justice and Equality Movement) 53-4

Pope John Paul II 159

Johnson, I. 32

Johnson, Mercy 45

Johnson-Sirleaf, Ellen 52, 53

Jonas, Mcebisi 108

Jonathan, Goodluck 44, 62-3, 69, 71

Joshua, Anthony 50

Joshua, Temitope 50

Jubilee Party in Kenya 166

Julius Caesar 35
Ka-Ncube, Sello Maake 83

Kabbah, Ahmed 53

Kabbah, Tejan 50, 51

Kabila, Joseph 95

Kabila, Laurent 95, 97, 112

Kae-Kazim, Hakeem 48

Kagwanja, P. 158, 160, 161, 162

Kagwanja, P. and Southall, R. 165

Kanayo, Kanayo O. 45

KANU (Kenya African Democratic Union) 167

Karago, Sally 150

Kardashian, Kim 175

Karidjo, Mahamadou 70

Kasambala, Tiseke 114

Kaveke, John 150

Keino, Kipchoge 151

Kendall, S. 163

Kenya 3, 9; Africa Policy Institute 154; AGOA (African Growth and Opportunity Act, US 2000) 150; AMSOM

(African Union Mission in Somalia) participation 161-2; Anglo-Leasing Procurement scandal (2005) 169; AntiCorruption Commission, establishment of 169; athletes, influence of 150-52; athletics success in 174; CGTN (China Global Television Network) in 9; Chicken Gate scandal (2014) 169; CMC di Ravenna corruption scandal (2019) 169; COMESA (Common Market for East and Southern Africa) 158, 160, 161; Corruption Perception Index 170; countries of origin of tourists in 153; cultural symbolism of Harambee in 34-5; EAC (East African Community) and 154, 158, 161, 166, 169, 178; EACG (Ethics and Anti-Corruption Commission) 169; economic diplomacy 157-9; economic power of 4; electoral violence 164-7; ERS (Economic Recovery Strategy for Wealth and Employment Creation) 158-9; ethnicity, constraint of 167-8; fashion industry, influence of 149-50; Foreign Affairs and International Trade, Ministry of 153-4, 156; foreign policy objectives 156; foreign policy of, cautious and dovish nature of 155-7; Global Tourism Forum 153; Goldenberg scandal (1990-93) 169; Government of 158-9; Grand Regency Hotel scandal (2008) 169; Harambee in 1, 3, 8, 9, 149, 154-5, 156, 176, 177-8; Hell's Gate National Park 152; Human 
Rights Commission 169; IAAF (International Association of Athletics Federations) top medalists 151; ICG (International Criminal Court) and 9, 149, 162-4, 178; IEBC (Independent Electoral and Boundaries Commission) 165; IGAD (Intergovernmental Authority on Development), membership of 154, 161; indigenous communities and Harambee in 33-4; International Camel Derby Festival 152; International Development Department 164-5; International Trade Centre 150; Jubilee Party 166; KANU (Kenya African Democratic Union) 167; Lake Turkana Cultural Festival 152; Lamu Cultural Festival 152; Lamu Island 152; landscapes, influence of 152-4; Maralal Camel Derby in 152, 178; Masai Mara National Reserve 152; Mombasa International Cultural Festival 152; Mount Kenya 152, 177-8; multilateralism of 162; multiparty politics in, emergence of 166; Nairobi National Park 152, 177-8; NASA (National Super Alliance) 166; obstacles to soft power in 178; PanAfricanism of 160-61; peace diplomacy 159-62; political corruption 168-70; RECs (Regional Economic Communities) 161; Rusinga Cultural Festival in 178; Safari Rally 152; self-help systems in 177-8; Sendai Framework for Disaster Risk Reduction 154; soft power currencies of 149-62; soft power in, scholarship on 7; soft power of, constraints on 162-70; sports diplomacy 150-52; strategic location of 178; Textile and Fashion Industry Report 150; TFTA (Tripartite Free Trade Area) 161; TICAD (Tokyo International Conference on African Development) and 161; tourism in, economic contribution of 9; tourism in, influence of 152-4; Toyota in 9; Triton Oil Corruption scandal (2009) 169; Turkwel Hydroelectric Power Station scandal (1986-90) 169; values of Harambee in 33, 34; wildlife, influence of 152-4; World Humanitarian Summit 154; WTO (World Trade Organisation) and 161, 162

Kenya Today 160

Kenyatta, Jomo 32-3, 34, 159, 160, 164, 167
Kenyatta, Uhuru 116, 117, 160-63, 165, 166

Khadiagala, G. and Nganje, F. 91, 95, 96, 98, 110-12, 117

Khumalo, Leleti 83

Khumalo, T. 114-15

Kibaki, Mwai (and administration of) 33, 153, 155, 157-8, 160-61, 165, 167, 168

Kim Jong Il 13

King Jnr., Martin Luther 90

Komsokolskaya Pravda 23

Koroma, Ernest Bai 52

Koromah, Major Johnny P. 50, 51

Kosgey, Henry 162

Krings, M. and Simmert, T. 43, 45, 47-8

Krippahl, C. 114

Kuna, M. 53, 60

Kurlantzick, J. 16, 17

Kwatemba, S. 167

Kwesta 83

Kyle Deutsch 84

Ladoja, Rashidi 65

Lake Turkana Cultural Festival in Kenya 152

Lalbahadur, A. 115

Lamu Cultural Festival in Kenya 152

In the Land of Tutankhamun (film by

Mohammed Bayoumi) 133

Landsberg, C. 94, 95, 97, 98, 110, 111

landscapes of Kenya, influence of 152-4

Langa, Pius 91-2

Langer, C. 36

Laroupe, Tegla 151

Larsen, H. and Sheel, A. 151

Laruelle, M. 22

Le Pere, G. 93, 112, 114, 115, 116

Leijenaar, A. 135-6, 137

Lemar 48

liberal values in South Africa, influence of 89-92

Liberia 91, 94, 105, 135, 160; democracy promotion in 176; Nigerian influence in 45, 57, 58-9, 60, 62, 66, 69, 71, 74;

Nigerian peace mission in 52-3, 54; peace diplomacy in 41

Lietzelman, H. 35, 124

Lionheart (film by Genevieve Nnaji) 43

Lira 83

literary icons, influence of: Egyptian 134-5; Nigerian 50

Long, J., Kanyinga, K., Ferree, K., and Gibson, C. 165

Loops, Jeremy 84 


\section{Index}

Louis Vuitton 49, 175

Louw-Vaudran, I. and Diatta, M. 114

Lugano, G. 162, 163

Lula da Silva, Luis Inacio 19

Mabera, F.: Kenya 157, 159, 160-61, 162, 163; South Africa 94-5, 104, 115

McBain, W. 42, 43

McCreath, Ann 150

Mada Masr 105-6

Madise, D. and Isike, C. 29, 30, 94

Madueke, Alison 64

Maduekwe, Ojo 69

Magu, Ibrahim 64

Mahamat, Moussa Faki 70

Mahfouz, Naguib 134, 175

Mail \& Guardian 45, 88, 107, 113

Makeba, Miriam 83

Malek, Rami 133

Mali 21, 87, 94, 113, 135, 161, 164;

Nigerian influence in 57, 60, 62, 66, 70, 75; Nigerian peace mission in $52-3,54$

MAMA Awards (2015 and 2016) 46-7

Mandela, Nelson (and administration of 5, 29, 176; South Africa 82, 85, 90, 96-7, 109, 111

Mane, Saido 130

Mantashe, Gwede 108

Maralal Camel Derby in Kenya 152, 178

Maroud, Aly 134

Masai Mara National Reserve 152

Masekela, Hugh 83, 84

Mashaba, Herman 113

Mason, R. 133, 138, 143

Massoud, Mena 133

Masters, L. 6, 90, 91, 106-7

Masuku, Bandile 108

Matilda, O. 166-7

Mavins 46

Mbatha, Nomzamo 83

Mbeki, Thabo 7, 50, 61, 90-91, 95, 110 , 113, 177

Mbela, Patricia 150

Mbete, Baleka 107

Mbithi, P. 33

Meek Mill 175

Meighan, R. 141

Melcangi, A. and Dentice, G. 139, 141, 142

El-Menawy, A. 142-3, 144

El-Meneai, Hossam Eddin 134

De Menezes, Fradique 50, 51

Mentor, Vytjie 108

Merkel, Angela 49
Messi, Lionel 132

Miccoli, D. 36, 125

Migai, A. 168

Migrant Acceptance Index (2017) 113

Miller, J. 42

Mills, K. and Bloomfield, A. 163-4

Mimiko, N.O. 55

Minaj, Nicki 175

MINURSO (UN Mission for Referendum in Western Sahara) 135

MINUSMA (UN Multidimensional Stabilization Mission in Mali) 54, 135

MINUSTAH (UN Stabilization Mission in Haiti) 135

Miyandazi, L. 157

Mobutu Sese Seko 95

Modi, Narendra 160

Moi, Daniel arap 159-60, 162

Mombasa International Cultural Festival 152

Monier, E. 128

MONUSCO (UN Organization Stabilization Mission in DRC): Egypt and 135; Nigeria and 54; South Africa and 95

Moore, C. 90

Morjaria, Vaishali 150

Morocco 3, 24, 66, 68, 130, 149, 155, 160, 178; economic power of 4

Morsi, Mohammed 137, 138, 139, 140

Moscow Times 22

Mosisili, Pakalitha 97

Motshegwa, Moshidi 83

Mount Kenya 152, 177-8

MPLA (Popular Movement for the Liberation of Angola) 58-9

Mpungu, P. 169

Mr Eazi 47

MTN Group, Johannesburg 87, 101-3, 159

MTV Africa Music Awards (MAMA): Nigeria 46-7; South Africa 83-4

Mubarak, Hosni 139, 140, 177

Mugabe, Robert 97-8, 99, 101, 109, 110 , 111,115

Muhammad, A. and Salawu, I. 64

Muhammad-Bande, Tijjani 63

multilateralism of: Kenya 162; Nigeria 59-63; South Africa 96-101

multinational corporations in South Africa, influence of 101-3

multiparty politics in Kenya, emergence of 166

Murage, J. 33, 34 
Murtala, Muhammad (and administration of) 60

Museum of Islamic Art in Egypt 35-6

Museveni, Yoweri 159

music and entertainment, influence of 83-5

Muslim Brotherhood in Egypt 123, 138, 139,140

Mutahi, P. and Ruteere, M. 166

Muthaura, Francis 162

Mwanika, P. 7

Mwatela, Jacinta 168

NAC (New Agenda Coalition) in South Africa 100

Nafi, B. 126, 143

Naija swagger 48, 75n 1

Nairobi National Park 152, 177-8

Nakhleh, E. 140

NAM (Non-Aligned Movement) 99

Napoleon Buonaparte 35

NASA (National Super Alliance) in Kenya 166

Nasser, Gamal Abdel 36, 128; Pan-Arabism of 125-7, 129

NATAG (Sierra Leone Peacekeeping Mission) 62

National Planning Commission in South Africa 89, 159

Ncube, G. 85

Ndereba, Catherine 151

Ndlovu, S. 86-7

NDP (National Development Plan) in South Africa 88-9

Ne-Yo 175

Nehru, Jawaharlal 25

Nene, Nhlanhla 108

NEPAD (New Partnership for African Development) 177; Nigeria and 50-51, 57, 59, 62; South Africa and 90, 91, 98-9

Netanyahu, Benjamin 160

Netherlands, soft power score for 2

New York Times 127, 168

New Zealand, soft power score for 2

Newes 2489

Neymar 27

Ngige, Chris 65

Nginya, M. 166

Nicki Minaj 47

Nigeria 3, 8; African Development Bank (ADB), TAC and 59; African humanism, lessons of 31; African Union (AU) and 50-51, 60-62; African Union (AU) and, TAC and 59; AFRICOM (US

African Command) and 72-3; Afrobeats of 4, 8, 41, 46-9; AGA (African

Governance Architecture) 62; AGOA

(African Growth and Opportunity Act, US 2000) 150; ANG (African National

Congress) and 58; APRM (African Peer

Review Mechanism) and 59, 62; APSA

(African Peace and Security Architecture) 62; AU Peace and Security Council (PSC) 61; BBC News 45, 65, 67, 69; Boko Haram terrorism 41, 69-72; Cameroon, crisis over Bakassi Peninsula with 53; China, great power influence on 73-4; conflict resolution, significance of 32; Congo Democratic Republic (DRC), peace mission in 52-3; Copyright Commission 43; corporate influencers 49; Corruption Perception Index 65; CSSDCA (Conference on Security, Stability, Development and Co-operation in Africa) 61; Dangote Group, influence of 49; democracy deficit 63-7; democracy promotion 50-52; diaspora of, influence of 50; Drugs and Crime, UN Office on 63, 64, 67; ECOMOG (Economic Community of West African States Monitoring Group) and 51, 59, 61; economic power of 4; ECOWAS (Economic Community of West African States) mediation process and 51-2, 53, 57-8, 59-60; EFCC (Economic and Financial Crimes Commission) 64; fashion industry, influence of 49; FDI (Foreign Direct Investment) and 63; First Bank, influence of 49; France, great power influence on 74-5; freedom in Africa 66; The Gambia, democracy promotion in 41; Globacom Group, influence of 49; global governance, UN and efforts at 62-3; Global Soft Power Index for 3; Government grants for Nollywood 44; great powers, influence on 72-5; ICPC (Independent Corrupt Practices and Other Related Offences Commission) and 63; illicit drugs hub 68; image crisis 67-9; INCB (International Narcotics Control Board) 68; JME (Justice and Equality Movement) and 53-4; Liberia, peace diplomacy in 41; Liberia, peace mission in 52-3; literary icons, influence of 50; Mali, peace mission in 52-3; MPLA 
(Popular Movement for the Liberation of Angola) and 58-9; MTV Africa Music Awards (MAMA) 46-7; mutilateralism of 59-63; Naïa swagger 48, 75n 1; NATAG (Sierra Leone Peacekeeping Mission) and 62; NEPAD (New Partnership for Africa's Development) and 50-51, 57, 59, 62; Nollywood in 4, 6, 7, 8, 41, 42-6, 174; OAU (Organisation of African Unity) and 51, 59; Omolúwàbi in 1, 8, 41, 55-6, 176; ONUC (Congo Peacekeeping Mission, 1960-64) 62; Pan-African issues 41; peacekeeping operations, long tradition of 53; peacemaking and peacekeeping 52-5; political corruption 63-7; PricewaterhouseCoopers 42, 43, 46, 63; RCGG (Redeemed Christian Church of God) 50; São Tomé and Príncipe, democracy promotion in 41 ; Sierra Leone, peace diplomacy in 41 ; Sierra Leone, peace mission in 52-3; soft power currencies 42-50; soft power in, scholarship on 6-7; soft power of, constraints on 63-72; soft power resources, deployment of 41-2; SPLM (Sudan People's Liberation Movement) and 53-4; Sudan, peace mission in 52-4; TAC (Technical Aid Corps) 56-9; TAC (Technical Aid Corps), commendations for 57-8; TAC

(Technical Aid Corps), scheme in 7, 8; Textile and Garment Intervention Fund 49; Tiger Global Management and Kinnevik, Nollywood and 44; UNAMID (UN African Union Mission in Darfur) and 54; UNAVEM II (Angola Peacekeeping Mission, 1991-2) 62; UNAVEM III (Angola Peacekeeping Mission, 1992-5) 62; UNIFIL (Lebanon Peacekeeping Mission, 1978-83) 62; UNIIMOG (Iran-Iraq Peacekeeping Mission, 1988-91) 62; UNIKOM (Iraq-Kuwait Peacekeeping Mission,1991) 62; UNIPOM

(India-Pakistan Peacekeeping Mission, 1965-6) 62; United Nations (UN) peacekeeping missions, contributions to 54; United Nations (UN) Security Council non-permanent membership 62-3; United States, great power influence on 72-3; UNMSIL (Sierra Leone, UN Mission to, 1991-2000) 62; UNOSOM (Somalia Peacekeeping
Mission, 1992-4) 62; UNPROFOR (Yugoslavia Peacekeeping Mission, 1992) 62; UNSF (New Guinea

Peacekeeping Mission, 1992-3) 62; UNTAG (Namibia Peacekeeping Mission, 1989-90) 62; UNTSO (Israel Peacekeeping Mission, 1995) 62; values of Omolúwàbi in 31-2; WHO (World Health Organisation), TAC and 59; Winners Chapel International 50; World Bank and 43, 44; Yoruba community in 31 , 48, 55; Zenith, influence of 49

Niniola 47

Njiru, J. 150

Nkandla Report in South Africa 107-8

Nkoana-Mashabane, Maite 104

Nkrumah, Kwame 160

Nkurunziza, Pierre 95

Nnaji, Genevieve 43, 45

NNWS (Non-Nuclear Weapons State) 99

Noah, Trevor 84

Nollywood in Nigeria 4, 6, 7, 8, 41, 42-6, 174; government grants for 44

Norbrook, N. 46, 47, 48

Norway, soft power score for 2

Ntshinga, Ndumiso 114

Nuclear Non-Proliferation Treaty: extension of (1995) 177; Review Conference (2000) 99-100

Nujoma, Sam 57

Nussbaum, B. 28, 29, 30-31, 94

Nwannennaya, C. and Abiodun, T. 68

Nwude, Emmanuel 67

Nye, Joseph 1, 6, 8, 52, 57, 90, 101, 162; soft power, conceptualisation of 12-15, 175-6; soft power, de-Americanisation and Africanisation of 16, 17, 18, 21, 25, $26,27,35$

Nyerere, Julius 157

Nyovest, Cassper 83, 84

OAU (Organisation of African Unity) 136, 159-60; Nigeria and 51, 59, 60, 61; South Africa and 90, 91, 97, 98

Obama, Barack 14, 49, 138, 160

Obama, Michelle 49, 175

Obasanjo, Olusegun (and administration of) 7; Nigeria 50-51, 52, 53, 60, 61-2

Obi, C. 50, 53

October 1st (film by Kunle Afolayan) 43

Odinga, Oginga 167

Odinga, Raila 165-6 
Offiah, C. 49

Ogbonna, C. and Ogunnubi, O. 58

Ogunbadejo, O. 59, 61

Ogunnubi, O. and Amao, O. 5, 117

Ogunnubi, O. and Isike, C. 4, 6, 45, 50

Ogunnubi, O. and Okeke-Uzodike, U. 4, 83, 84, 85, 101

Ogunnubi, O. and Tella, O. 101, 102

Ogunnubi, O., Onapajo, H. and Isike, C. $70,71-2$

Ogunnubi, Olusola 5, 99-100

Oh, E. 42, 43, 44

OIC (Organisation of Islamic Conference) 136

Ojo, G. and Aghedo, I. 67, 68

Ojo, O. 31, 60

Okayafrica 84

Oke, Femi 50

Okeke, Obinwanne 67

Okello, Tito 159

Okonedo, Sophie 48

Okonjo-Iweala, Ngozi 63

Olamide 46

Olanipekun, O. 55

Olivier, G. 91

Olowu, Duro 49

Olsen, G. 157

Omo-Ogbebor, D. 60

Omolúwàbi in Nigeria 1, 8, 41, 55-6, 176

Omotola 51, 52

Onapajo, H. and Isike, C. 115-16

Onifade, T.A. 31-2

Onishi, Norimitsu 42, 43

ONUB (UN Operation in Burundi) 95

ONUC (Congo Peacekeeping Mission, 1960-64) 62

Onyeama, Geoffrey 114

Open Society Foundation 169-70

Oripeloye, H. and Omigbule, M. 31, 32

Orji, Yvonne 48

Orji, Zack 45

Orora, J. and Spiegel, H. 33, 154

Oshewolo, S. 58, 60, 61-2

Osondu, M. 59

Osuntokun, A. 58

Ottawa Process (1997) 177

Ouattara, Alassane 75, 110

Owoyemi, M.Din, A. and Ahmad, Z. 67, 68

Oxford Business Group 152, 153

Oyakhilome, Chris 50

Oyedepo, David 50

Oyelowo, David 48

Ozokwor, Patience 45
P Square 46

Padmore, George 160

Pan-Africanism: Kenya and 160-61;

Nigeria and 41

Pan-Arabism: contemporary Pan-Arabism in Egypt 127-8; Egyptian concept 9, 177; of Nasser in Egypt 125-7

Patoranking 46, 47

Paul Smith 49, 175

PCRD (Post-Conflict Reconstruction and Development) in Egypt 136

peace diplomacy: Kenya and 159-62;

South Africa and 94-6

peacekeeping (and making): Nigeria and 52-5; South Africa and 91

Pele 26

Pereira, Major Fernando 51

Pew Research Center 15

The Philanthropist (film) 68

Ping, Dr Jean 92

Poland, soft power score for 2

political corruption: in Kenya 168-70; in

Nigeria 63-7

political instability in Egypt 139-40

political quagmire in South Africa 106-9

Popescu, N. 23

Portland 1-3

Portugal, soft power score for 2

Poverty Trends report (2017) for South Africa 106

Powell, Colin 100

Premium Times 69

PricewaterhouseCoopers in Nigeria 42, 43, 46,63

Prinsloo, B. 95

professionals from Egypt, impact of 129

Public Protector in South Africa 107

Purushothaman, U. 24, 25

Putin, Vladimir 21, 137

Qobo, M. and Nyathi, N. 28, 29, 30, 93-4

The Queen (TV show) 84, 85

El Rahim, A. 7, 125, 126

Rajaonarimampianina, Hery 96

Rajoelina, Andry 96

Ramaphosa, Cyril 108, 114

Ramo, J. 19

Ravalomanana, Marc 96

RCGG (Redeemed Christian Church of God) in Nigeria 50

Recchia, S. 75

RECs (Regional Economic Communities) in Kenya 161 


\section{Index}

Reuters 17, 139, 141

Rhythm City (TV show) 83, 84

Rick Ross 175

Ricky Rick (Nafukwa) 84

Riggs, C. 35-6, 123-4

Rihanna 83, 175

Rio Times 27

The River (TV show) 83, 84

Rivera, J. 136

Rombo, D. and Lutomia, A. 31

Rome Statute (1998) 177

Ronaldinho 27

Ronaldo, Christiano 26-7, 132

Rotich, Henry 169

Rousseff, Dilma 28

Rubin, L. 126

Rugby World Cup (1995) in South Africa 85

Rusinga Cultural Festival in Kenya 178

Russia Today 16, 175

Russian Federation: American influence, counteraction against 23; attraction, limits on power of 23-4; language, pull-factor of 22; positive perceptions of, promotion of 23; Russiky Mir Foundation 23; soft power of, sources of 21-2; soft power resources of 8, 175; soft power score for 2; 'sovereign democracy' of 23

Ruto, William 117, 162, 163

Rwanda 53, 62, 66, 72, 135, 178; gender equality in 174; growth rate in 174 ; Kenya and 158, 159, 161, 164; South Africa and 91, 92, 94, 95, 102, 111, 113,115

SACU (South African Customs Union) 99, 105, 177; South Africa 99

SADC (South African Development Community) 74, 86, 87, 92, 96, 97, 98-9, 106, 111, 161, 177

Safari Rally in Kenya 152

El Safty, A. 142

Sagoe, Deola 49

Al-Said, Nuri 126

Sakaguch, Nelson 67

Salah, Mohammed ('Mo') 123; sport diplomacy and Mo Salah effect 130-32

Salako, Tokunbo 50

Salamé, Ghassan 143

SALC (Southern African Litigation Centre) 101

Saliu, H. and Omotola, S. 58

Sanda, J. 53
Sang, Joshua arap 162

Sanogo, Captain Amadou 52

São Tomé and Príncipe: democracy promotion in 176; Nigeria and 41, 50, $51,66,94$

Saro-Wiwa, Ken 111

Sawt al-Arab (Voice of the Arabs) 126

Sayed, N. 134, 143

Scandal (TV show) 83, 84

Schmidt, Dana Adams 127

Schmidt, Eric 45

Schoeman, Maxi 89, 104

Schoole, C. 87

Schuster, Leon 83

Seal 48

Sendai Framework for Disaster Risk

Reduction 154

Seymour, M. 15

Shambaugh, D. 17

Sharma, K. 133

Sharp, J. 138, 140

Shekau, Abubakar 70

Shekinah 84

Sho Madjozi 83

Shuttleworth, Mark 89

Sidiropoulos, E. 4, 91-2, 101, 104

Sierra Leone 105, 113, 160; democracy promotion in 176; Nigerian influence in 50-54, 57, 58-60, 62, 66, 69, 71, 74, 79; Nigerian peace mission in $52-3$; peace diplomacy in 41

Simelane, Percy 107

Simon Webbe (Blue) 48

Singapore, soft power score for 2

Singh, R. 89

Singleton, J. 151

El-Sisi, Abdel Fattah 137-8, 139-40, 142,144

Sisulu, Walter 90

Sjava 83

skilled workers from Egypt, emigration of 128-30

Slumdog Millionaire (film) 24

Smith, K. 4, 5, 6

Snoop Dog 47

soap operas from South Africa, influence of $83-5$

soft power: African capacity for 1, 174, 175; Africanisation and de-Americanisation of concept 8; Africanisation of 28-36; attraction, power of 13 ; $\mathrm{BBC}$

(British Broadcasting Corporation) 16; Brazil, samba and carnivals in 26-8; China, charm offensive of 16-21; CNN 
(Cable News Network) 16; constraints on Kenyan power 162-70; constraints on Nigerian power 63-72; constraints on South African power 5; culture as source of 14-15; de-Americanisation of 15-16; decline of Egyptian power 138-44; definition of 1; Discovery Network 16; Egypt, Pharaonism in 28, 35-6; of Egypt in Yemen, salience of 127; ESPN (Entertainment and Sports Programming Network) 16; Ferguson's criticism of 15; government policies and 13-14; Gramsci on 14; hard command power 12-13; India, pacifism and Bollywood in 24-6; Kenya, Harambee in 28, 32-5; Nigeria, Omolúwàbi in 28, 31-2; Nye's conceptualisation of 12-15; preference shaping 14; relevance in international politics 1-3, 13; resources of Nigeria, deployment of 41-2; rise of Egyptian power 123-38; Russian Federation, resurgence of 21-4; scholarship on 4-7; social media and 16; soft cooptive power 12-13; sources of 175-6; South Africa, Ubuntu in 28-31; in South Africa, challenges to 103-17; United States and 15-16

The Soft Power 30 (Portland) 1-3

soft power currencies: in Kenya 149-62; in Nigeria 42-50; in South Africa, dampening of 82

Soft Power (Nye, J.) 13

South Africa 3, 8-9; admired African brands 102-3; AFCON (Africa Cup of Nations) 86-7; AfCTA (African Continental Free Trade Agreement) 115; Africa, Janus-faced nature of relationship with 115-17; African Union (AU) inaugural summit (2002) 97; AMIB (AU Mission to Burundi) 95, 98; ANC (African National Congress) 29; ANWFZ (African Nuclear Weapons Free Zone Treaty) 100; APRM (African Peer Review Mechanism) and 90, 98-9; APSA (African Peace and Security Architecture) 95; Arusha Peace and Reconstruction Agreement (2000) 95; AU Peace and Security Council (PSG) 114; BET (Black Entertainment TV) 83; BRICS associations 30, 82, 94, 97, 104, 105; CAF (Confederation of African Football) 86; charismatic leaders, influence of 89-92; civil society organisations, influence of 101-3; COSATU
(Congress of South African Trade Unions) 101, 108; CRAI (Citizenship Rights in Africa Initiative) 112; Cricket World Cup (2003) in 85; Cybernetics Lab top African universities 88; democracy promotion 94-6; democracy promotion, shortfall on 109-12; diplomacy of Ubuntu, White Paper on 30-31;

DIRCO (Department of International Relations and Cooperation) 93-4, 101, 104, 112; economic constraints on 104-6; economic power of 4; environmental politics, role in 100-101; FIFA World Cup (2010) in 8, 85-6, 90, 174; Global Peace Index 105; Global Soft Power Index for 3; Government of 30, 93, 106; Gupta family (Guptagate and) 108; higher education, influence of 87-9; HIV/AIDS infections 86; human rights, double standards on 109-12; Human Rights Watch World Report (Johannesburg, 2014) 114; IBSA (IndiaBrazil-South Africa Dialogue Forum) 82; ICG (International Criminal Court), stance on 116-17; industrial investments by South African companies 103; inequalities in 104-5; liberal values, influence of 89-92; Migrant Acceptance Index (2017) 113; MONUSCO (UN Organization Stabilization Mission in Democratic Republic of Congo) 95; MTV Africa Music Awards (MAMA) 83-4; multilateral foreign policy 96-101; multinational corporations, influence of 101-3; music and entertainment, influence of 83-5; NAG (New Agenda Coalition) 100; NAM (NonAligned Movement) 99; National Planning Commission 89, 159; NDP (National Development Plan) 88-9; NEPAD (New Partnership for African Development) and 90, 91, 98-9; Nkandla Report 107-8; NNWS (NonNuclear Weapons State) 99; Nuclear Non-Proliferation Treaty Review Conference (2000), role in 99-100; OAU (Organisation of African Unity) and 90, 91, 97, 98; ONUB (UN Operation in Burundi) and 95; peace diplomacy 94-6; peacemaking by 91, 177; political quagmire in 106-9; Poverty Trends report (2017) 106; Public Protector 107; quintessential soft power state 176-7; Rugby World Cup (1995) in 85; SACU 


\section{Index}

(South African Customs Union) 99;

SALC (Southern African Litigation

Centre) 101; soap operas, influence of

83-5; soft power currencies of, dam-

pening of 82; soft power of, challenges

to 103-17; soft power of, constraints on

5; soft power of, scholarship on 6-7; soft power of, sources of 83-103; sporting events, influence of 85-7; Stats SA 106;

Times Higher Education top African universities 88; Towards Inclusive Economic Development (SATIED) programme 106; transition experience 91-2; TRC (Truth and Reconciliation Commission) 29, 82, 84, 91-2, 93; Ubuntu in 1, 8, 56, 82, 93-6, 115, 176-7; UN World Conference against Racism, Xenophobia and Related Discrimination (2001) 97; UN World Summit on Sustainable Development (2002) 97; United Nations (UN) Resolution 1973, vote on 117; United Nations (UN)

Security Council non-permanent membership 98-9; values of Ubuntu in 29-30; violent state, image as 105-6; Women, UN World Conference on (China, 1995) 116; World Economic Forum 92; xenophobia in, incessant nature of 112-15

South Korea, soft power score for 2

South Sudan 21, 54, 66, 94, 97, 135, 136, 178; Kenyan influence in 154, 156, 157, 158, 160, 161

Soyinka, Wole 45, 50, 175

Spain, soft power score for 2

SPLM (Sudan People's Liberation Movement) 53-4

Spooner, Samantha 88

sport diplomacy, Mo Salah effect and 130-32

sporting events in South Africa, influence of $85-7$

sports diplimacy of Kenya 150-52

Springborg, R. 141

Stats SA 106

Stefani, Gwen 175

strategic location of Kenya 178

Sudan, Nigerian peace mission in 52-4

Suharto of Indonesia 110

Sun, Y. 74

Sundberg, A. 75

Super Sport 130

Sweden, soft power score for 2

Switzerland, soft power score for 2
TAC (Technical Aid Corps) in Nigeria 56-9; commendations for 57-8; scheme of 7, 8; Technical Aid Corps

Directorate 57

Tadros, S. 134, 143

Taio Gruz 48

Talla, O. and Ogunnubi, O. 5

Tambo, Oliver 90

Tanzania 3, 43, 53, 66, 149, 153, 157-8, 160,166 ; South African influence on 92, 97, 101-3, 105, 114

Taylor, Charles 53

Tekno 46, 47, 48

Tella, O. 1, 4, 5, 6, 7; Nigeria 45, 49, 51-3, 57-8, 60, 62, 64, 65, 70-74; soft power, de-Americanisation and Africanisation of 13, 21, 29, 30; South Africa 86-7, 90-91, 94, 97-9, 100, 102, 105, $107,109-13$

Tella, O. and Ogunnubi, O. 114

Tergat, Paul 151

Textile and Fashion Industry Report in Kenya 150

Textile and Garment Intervention Fund in Nigeria 49

TFTA (Tripartite Free Trade Area) 161

Theron, Charlize 89

This Day 69

Three Idiots (film) 24

Thusi, Pearl 83

Thussu, D. 16, 24

TICAD (Tokyo International Conference on African Development) 161

Ticku, T. 61

Tiger Global Management and Kinnevik, Nollywood and 44

Time magazine 16, 130, 132, 133

Times Higher Education 87-8; top African universities 88

Tiwa Savage 46, 47

Tlale, David 49

Togo 103, 115, 135; democracy promotion in 176; Nigerian influence in $43,52,53$, $59,60,61,62,66,71,74$

Tourangham, M. 25

tourism in Kenya: economic contribution of 9; influence of 152-4

Toyota in Kenya 9

Transparency International 65, 71, 170

TRC (Truth and Reconciliation Commission) in South Africa 29, 82, 84, 91-2, 93

Trinkunas, H. 27-8

Triton Oil Corruption scandal (2009) in Kenya 169 
Trump, Donald 14, 137, 138

Tsourapas, G. 127, 128, 129, 130

Tsvangirai, Morgan 97

Tsygankov, A. 22

Tucker, R., Onywera, V., and Santos-Concejero, J. 151

Tunde Baiyewu 48

Turkey, soft power score for 2

Turkwel Hydroelectric Power Station scandal (1986-90) in Kenya 169

Turpin, A. 103

Tutankhamen ('Tut') 124-5

Tutu, Desmond 91, 110

Twitter 16

Uba, Chris 65

Ubuntu in South Africa 1, 8, 56, 82, 93-6, $115,176-7$

Uganda 178

Ujara, E. and Ibietan, J. 69

Umezurike, S. Iwu, C. Asuelime, L. and Umezurike, C. 59, 61

Unger-Hamilton, Ferdy 48

United Kingdom, soft power score for 2

United Nations (UN) 54-5, 114, 135-6; Drugs and Crime, Nigeria and UN Office on $63,64,67$; peacekeeping missions, Egyptian contributions to 135-6; peacekeeping missions, Nigerian contributions to 54; regional office locations in Egypt 136; Resolution 1973, South African vote on 117; Security Council 8; Security Council non-permanent membership for Nigeria 62-3; Security Council non-permanent membership for South Africa 989; South Africa, stance on human rights in Zimbabwe and Myanmar 5; South African role at 177; UNAMID (AU-UN Hybrid Operation in Darfur) 54, 135; UNAVEM II and III 62; UNHCR 70; UNIFIL 62; UNIIMOG 62; UNIKOM 62; UNIPOM 62; UNMIL 135; UNMISS 135; UNMSIL 62; UNOCI (UN Operation in Côte d'Ivoire) 135; UNOSOM 62; UNPROFOR 62; UNSF 62; UNTAG 62; UNTSO 62; World Summit on Sustainable Development (2002) in South Africa 97

United States: AFRICOM (US African Command) 72-3; AGOA (African Growth and Opportunity Act, 2000): Kenya 150; great power influence on Nigeria 72-3; soft power score for (Soft Power 30) 2; Washington Consensus 18, 19 values of: Harambee in Kenya 33, 34;

Omolúwàbi in Nigeria 31-2; Pharaonism for Egypt 35-6; Ubuntu in South Africa 29-30

Van der Westhuizen, J. 4, 5, 97, 100, 116, 117

Van Wyk, J. 100

Vilane, Sibusiso 89

violent state, South African image as 105-6

VOA (Voice of America) 71

Wade, Abdoulaye 61, 98

Wagner, C. 25

Wale 48

Walji, Jamil 150

Wamanji, E. 150-51

Wanjiru, Samuel 151

Washington Post 23

Wassef, Aalam 134

WHO (World Health Organisation), TAC and 59

wildlife In Kenya, influence of 152-4

Winners Chapel International in Nigeria 50

Wizkid 46, 47, 48, 175

Women, UN World Conference on (China, 1995) 116

Wood, M. 125

World Athletics 151

World Bank 4, 104, 149, 155; Egypt and 123, 129, 141, 142; Nigeria and 43, 44

World Economic Forum 92

World Humanitarian Summit in Kenya 154

World Travel and Tourism Council 124, 152

WTO (World Trade Organisation) 161, 162

xenophobia in South Africa, incessant nature of 112-15

Xi Jinping 17, 49, 137

Xinbo, W. 21

Yadav, N. 28

Yar'Adua, Umaru Nusa 69

Yemi Alade 46, 47

Yoruba community in Nigeria 31, 48, 55

Al-Youm, A. 136

Yousra 134

Youssef, D. 133

Youssef, Ramy 133

YouTube 16

Yves Saint Laurent 175 


\section{Index}

Zaki, Adel Imam Ahmed 134

Zenawi, Meles 57

Zenith in Nigeria, influence of 49

Zhao, S. 19-20

Zimbabwe 5, 20, 43, 58, 61, 65, 66, 162; conflict zone 177; South Africa and 91-2, 94-9, 101-4, 108-15, 117

Zohry, A. 129-30

Zondi, S. 75

Zuckerberg, Mark 45

Zulu, Lindiwe 111

Zulum, Babagana 71

Zuma, Dr Dlamini 92

Zuma, Jacob (and administration of) 5, 86, 96, 103, 104, 107, 108, 111-13, 116, 177 